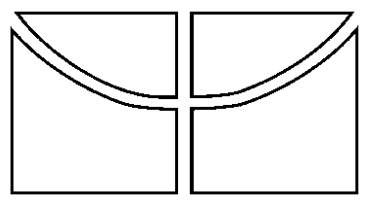

UNIVERSIDADE DE BRASÍLIA

FACULDADE DE COMUNICAÇÃO

PROGRAMA DE PÓS-GRADUAÇÃO

DISSERTAÇÃO DE MESTRADO

O desenvolvimento da internet e os grandes bancos:

um estudo a partir das iniciativas do Bradesco

Isabela Botelho Horta

Brasília, fevereiro de 2017 


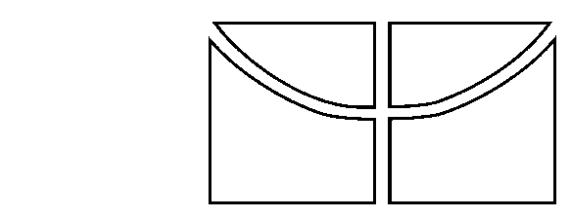

UNIVERSIDADE DE BRASÍLIA
FACULDADE DE COMUNICAÇÃ̃O
PROGRAMA DE PÓS-GRADUAÇÃO

\author{
DISSERTAÇÃO DE MESTRADO
}

\title{
O desenvolvimento da internet e os grandes bancos: um estudo a partir das iniciativas do Bradesco
}

Isabela Botelho Horta

Dissertação apresentada à Banca Examinadora para Defesa de Dissertação em Comunicação da Universidade de Brasília/UnB como parte dos requisitos para a obtenção do título de Mestre em Comunicação.

Linha de pesquisa: Políticas de Comunicação e de Cultura. Orientador: César Ricardo Bolaño. 
HORTA, I. B. O desenvolvimento da internet e os grandes bancos: um estudo a partir das iniciativas do Bradesco. Dissertação apresentada à Faculdade de Comunicação da Universidade de Brasília para obtenção do título de Mestre em Comunicação.

Aprovado em:

Banca Examinadora

Prof. Dr. César Ricardo Bolaño

Instituição: UnB/UFS

Julgamento: Assinatura:

Prof. Dr. Sivaldo Pereira da Silva Instituição: UnB/UFAL

Julgamento: Assinatura:

Prof. Dr. Carlos Peres de Figueiredo Sobrinho Instituição: UFS

Julgamento: Assinatura:

Profa. Dra. Christiana Soares de Freitas (suplente)

Instituição: UnB

Julgamento: Assinatura: 


\section{AGRADECIMENTOS}

Agradeço ao Paraná pelo incansável apoio ao longo deste trabalho. Obrigada pelas críticas e leituras e, principalmente, por me mostrar que quem não tem nada só tem sua disciplina. Sou profundamente agradecida por você ter compartilhado sua serenidade comigo nos últimos anos.

À Natália, veterana e grande incentivadora deste mestrado, meu abraço apertado. Obrigada por ouvir com tanta paciência minhas inquietações e por vibrar comigo em cada vitória.

A Luiz Antônio e Suely agradeço pelo imenso carinho e suporte material que sempre oferecem. Obrigada pelo ombro amigo a cada tombo e por continuamente apoiarem meus projetos.

Este mestrado não seria concretizável sem vocês quatro.

Ao meu orientador, prof. Dr. César Bolaño, agradeço por ter generosamente acolhido o projeto. Sou muito grata pelas leituras cuidadosas e orientação comprometida que tanto contribuíram para esta dissertação e minha formação acadêmica.

Agradeço também aos amigos que compreenderam o recolhimento nos últimos meses e proporcionaram momentos leves e divertidos nos meus momentos de descanso. 


\section{RESUMO}

Esta dissertação investiga a relação entre o desenvolvimento da internet no Brasil e a trajetória da automação bancária no país, a partir da abordagem da Economia Política da Comunicação. O objetivo é entender de que forma a rede mundial de computadores e as tecnologias da informação e da comunicação (TIC) influenciaram o processo de automatização e informatização dos bancos nacionais e, em sentido inverso, como estes buscam direcionar o desenvolvimento da internet no país a partir de seus interesses e necessidades. Para ilustrar esta análise, a dissertação lança luz sobre duas iniciativas de acesso grátis à internet oferecidas pelo banco Bradesco em 1999 e 2014. A partir de tais casos empíricos, também apresentamos na investigação o atual debate a respeito da neutralidade de rede e da permissibilidade de planos Zero Rating, trazidos à tona com a sanção e regulamentação do Marco Civil da Internet.

Palavras-chave: internet; automação bancária; Economia Política da Comunicação; Bradesco; sistema financeiro 


\begin{abstract}
This dissertation investigates the relationship between the development of the internet in Brazil and the trajectory of banking automation in the country, based on the approach of the Political Economy of Communication. The objective is to understand how the global computer network and information and communication technologies (ICT) have influenced the process of automation and computerization of national banks and, conversely, how they seek to direct the development of the internet in the country, from ther interests and needs. In order to illustrate this analysis, the dissertation sheds light on two initiatives of free internet access offered by Bradesco Bank in 1999 and 2014. From these empirical cases, we also present in the investigation the current debate about net neutrality and permissibility of Zero Rating plans, brought to light with the sanction and regulation of the Marco Civil da Internet.
\end{abstract}

Keywords: internet; banking automation; Political Economy of Communication; Bradesco; financial system 


\section{SUMÁRIO}

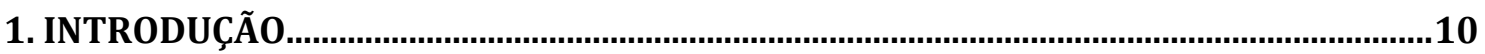

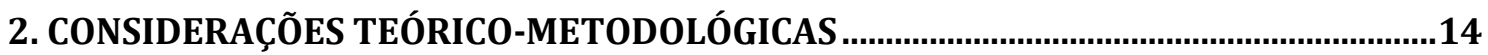

2.1 A ECONOMIA POLÍTICA DA COMUNICAÇÃO: FUNDAMENTOS INICIAIS ....................................15

2.2 FUNDAMENTAÇÃO TEÓRICA: A REESTRUTURAÇÃO DO CAPITALISMO E O

DESENVOLVIMENTO DAS TIC A PARTIR DÉCADA DE 1970 ……………………….........................27

2.3 MARCO CIVIL DA INTERNET E OS CONCEITOS DE NEUTRALIDADE DE REDE E ZERO RATING

3. O DESENVOLVIMENTO HISTÓRICO DA INTERNET NO BRASIL E NO MUNDO

3.1 DA GUERRA FRIA Å VIRADA DO MILÊNIO_ A GESTAÇÃO DA INTERNET NO BRASIL

4. O PROCESSO DE AUTOMAÇÃO BANCÁRIA E OS INTERESSES DOS BANCOS NO DESENVOLVIMENTO DA INTERNET …………………...........................................97

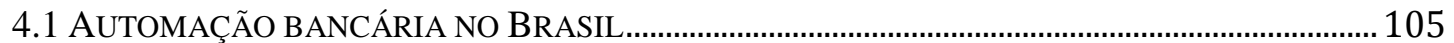

4.2 OS BANCOS E A INTERNET: OS CASOS BRADESCO DE 1999 E 2014 ………….......................122

4.3 OUTRAS OFERTAS DE INTERNET GRÁTIS ............................................................................... 137

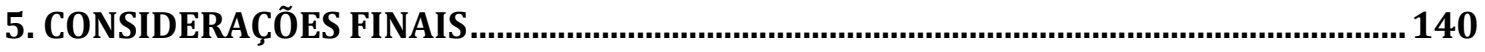

6. REFERÊNCIAS BIBLIOGRÁFICAS........................................................................146

APÊNDICE - CRONOLOGIA DO DESENVOLVIMENTO DA INTERNET E DA

AUTOMAÇÃO BANCÁRIA BRASILEIRA ...................................................................172 


\section{LISTA DE TABELAS}

Tabela 1 - Consultas públicas a respeito da neutralidade de rede .............................................49

Tabela 2 - Número de servidores interconectados no mundo de 1969 a 1989 .............................62

Tabela 3 - Evolução do uso da internet nos Estados Unidos de 1995 a 2014................................. 68

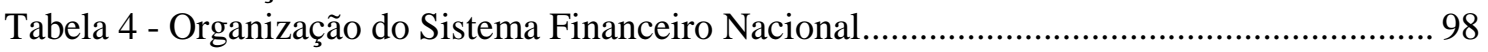

Tabela 5 - Maiores bancos brasileiros em número de ativos.......................................................102

Tabela 6 - Os seis maiores bancos em ativos em 1995 e em 2014 ..........................................103

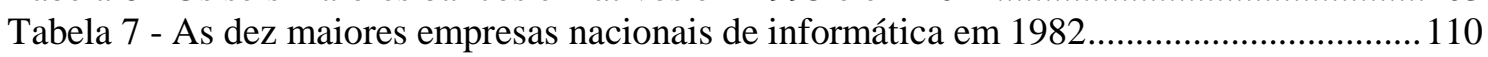

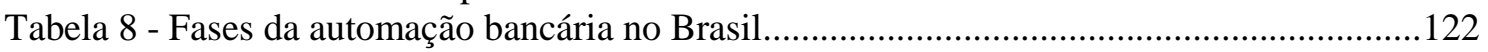

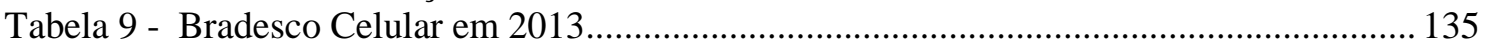

Tabela 10 - Transações bancárias do Bradesco realizadas via internet e mobile banking..........136

\section{LISTA DE GRÁFICOS}

Gráfico 1 - Evolução do uso da internet nos Estados Unidos de 1995 a 2014 68

Gráfico 2 - Distribuição geográfica de internautas em 2000, em milhões de usuários ............... 69

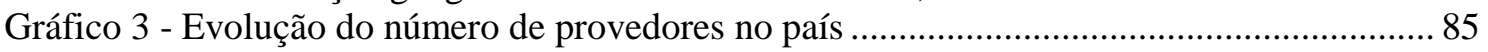

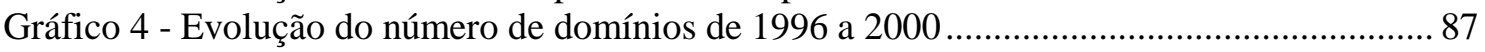

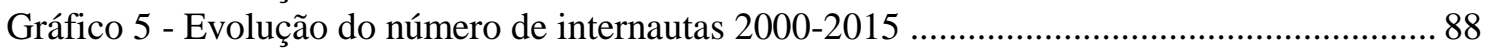

Gráfico 6 - Estimativas da população com cobertura de internet em 2015 ................................ 90

Gráfico 7 - Percentual de internautas que usam internet banking nos Estados Unidos ............. 116

Gráfico 8 - Transações e atendimentos por canais de atendimento dos bancos ........................ 118

\section{LISTA DE FIGURAS}

Figura 1 - Mapa das regulações sobre neutralidade da rede no mundo.......................................... 48

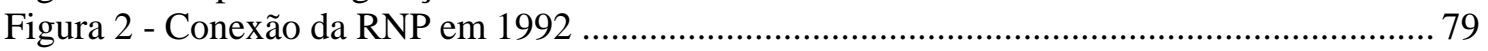

Figura 3 - Interconexões entre mídia multinacional e corporações da internet........................... 92

Figura 4 - Hieraquia de acesso à internet nos anos 2000 ...................................................... 128 


\section{SIGLAS}

Abranet Associação Brasileira dos Provedores de Acesso, Serviços e Informações da Rede Internet

Anatel Agência Nacional de Telecomunicações

ARPA Advanced Research Projects Agency

BBS Bulletin Board System

CGI.br Comitê Gestor da Internet

DTN Disruption-Tolerant Networking

ECC Economia da Comunicação e da Cultura

Embratel Empresa Brasileira de Telecomunicações

EPC Economia Política da Comunicação

EESPT Entidades Exploradoras de Serviços Públicos de Telecomunicações

FCC Federal Communications Comission

FMI Fundo Monetário Internacional e Organização Mundial do Comércio

GRESEC Groupe de Recherches sur les Enjeux de la Communication

IOS International Organization for Standardization

IOT Internet of Things

IMP Interface Message Processor

NIC.br Núcleo de Informação e Coordenação do Ponto BR

NSA National Security Agency

NASA National Aeronautics and Space Administration

OCDE Organização de Cooperação e Desenvolvimento Econômico

OMC Organização Mundial do Comércio

OSI Open Systems Interconnection

PSCI Provedor de Serviço de Conexão à Internet

RNP Rede Nacional de Pesquisa

SCI Serviço de Conexão à Internet

SFN Sistema Financeiro Nacional

SWIFT Society for Worldwide Interbank Financial Telecommunication

TIC Tecnologias da informação e comunicação

TCP/IP Transmission Control Protocol/Internet Protocol

UIT União Internacional de Telecomunicações 


\section{INTRODUÇÃO}

O presente trabalho se propõe a analisar, desde a perspectiva teóricometodológica da Economia Política da Comunicação, a relação entre o desenvolvimento da internet ${ }^{1}$ e a trajetória da automação e informatização dos bancos.

Busca-se com este objeto de estudo compreender como a rede mundial de computadores e as tecnologias da informação e da comunicação (TIC) influenciaram o processo de automação dos bancos nacionais e, em sentido inverso, como estes buscam direcionar o desenvolvimento da internet no país a partir de seus interesses e necessidades.

Para ilustrar esta análise, a dissertação lança luz sobre duas iniciativas de acesso grátis à internet oferecidas pelo banco Bradesco a seus correntistas. A primeira ação, "Rede Acesso Grátis", foi lançada em 1999, no contexto de profusão de provedores gratuitos no país e no mundo. A segunda, oferecida aos clientes do banco em 2014, o “Acesso Gratuito ao Bradesco Celular”, oferece, como o próprio nome já diz, a conexão gratuita aos clientes que acessarem o internet banking do Bradesco a partir de seus smartphones.

$\mathrm{O}$ destaque dado às iniciativas desse banco nesta dissertação foi motivado fundamentalmente por duas questões. Em primeiro lugar, após uma revisão histórica do desenvolvimento da internet no Brasil, observou-se que o Bradesco foi pioneiro nas duas iniciativas de internet grátis, ofertadas em conjunturas políticas, econômicas e sociais distintas. Além da reincidência histórica, motivou também esse recorte empírico a importância do Bradesco no mercado bancário nacional. Trata-se do segundo maior banco privado do país em número de ativos ( $\mathrm{R} \$ 9,5$ trilhões em junho de 2016). Recentemente, o Bradesco comprou o inglês HSBC por R 16 bilhões, o que fez aumentar em $15,9 \%$ seus ativos.

\footnotetext{
${ }^{1}$ Neste trabalho, como se observará nas páginas que se seguem, a palavra "internet" é grafada com a letra inicial minúscula. A dissertação segue a grafia utilizada no Marco Civil da Internet (Lei ${ }^{\circ}$ 12.965/2014, principal norma que disciplina o uso da internet no Brasil), que utiliza a palavra com o "i" em caixa baixa em todos os contextos semânticos. Há autores, no entanto, que defendem que o termo seja grafado com letra maiúscula, "Internet", para designar a rede mundial de computadores, de alcance global, e com inicial minúscula, "internet", para se referir a todo e qualquer conjunto de redes interligadas (LUCERO, 2011).
} 
A partir do objeto desta pesquisa e o recorte mencionado acima, as seguintes questões foram consideradas ao longo deste trabalho:

- Quais são as afinidades eletivas entre a trajetória da internet e da automação e informatização bancária no Brasil?

- De que forma as grandes instituições financeiras influenciam o desenvolvimento da internet a partir de seus interesses e necessidades?

- Que fatores levaram o Bradesco a lançar iniciativas de acesso grátis à internet em momentos tão distintos do desenvolvimento da internet no Brasil?

- Que compreensão tem o atual arcabouço regulatório do país a respeito das práticas de acesso grátis à internet?

Tais questões se revelam importantes se considerarmos que a formulação de políticas públicas é um importante lócus de disputa de diferentes atores sociais. A presente pesquisa, ao iluminar parte significativa do desenvolvimento da internet no Brasil, pretende contribuir para novas perspectivas interpretativas para os estudos de Políticas de Comunicação ao avaliar de que modo as ações de grandes instituições financeiras, o Bradesco no caso particular desse trabalho, tencionam o funcionamento técnico da internet brasileira e seu arcabouço regulatório.

Além disso, no atual cenário, em que são discutidos os desafios da universalização de acesso à rede, os conceitos de neutralidade de rede e a permissibilidade de planos Zero Rating, uma pesquisa sobre um modelo de provimento de conexão franqueada oferecido por um grande agente do mercado se faz necessário.

Além desses motivos, ao se voltar a iniciativas lançadas pelo Bradesco, a pesquisa também lança luz nas estratégias de atuação de uma das maiores instituições financeiras do país, com capilaridade em todo o território nacional, elevado índice de investimento em tecnologia e poder concentrado de ação e intervenção política, notadamente, mas não apenas, por meio de financiamento de campanhas eleitorais. Em 2014, o banco doou mais de 31 milhões de reais aos partidos PT, PMDB, PSDB e PSB ${ }^{2}$.

Considerando todas as questões até aqui mencionadas, foram estabelecidas, além do objetivo geral de estudar as afinidades existentes no desenvolvimento da

\footnotetext{
${ }^{2}$ As doações realizadas pelos bancos Bradesco, BTG Pactual, Itaú-Unibanco, Safra e BMG a quatro grandes partidos brasileiros (PT, PSDB, PMDB e PSB) nas eleições de 2014 podem ser visualizadas em: <http://www.asclaras.org.br/arvores/cinco_bancos.html>. Acesso em: 29 jan. 2017.
} 
internet e no processo de automação e informatização dos bancos, outros três objetivos específicos:

- Descrever a trajetória da internet no Brasil e no mundo, de seus antecedentes históricos até os dias atuais, identificando os principais eventos inseridos neste enredo;

- Compreender o processo de automação bancária brasileira e sua intersecção com o desenvolvimento da internet; e

- Identificar e apresentar as duas iniciativas do banco Bradesco e o contexto em que foram lançadas.

A partir de tais objetivos, e para dar cabo das questões propostas, o trabalho foi organizado em seis partes. Além desta introdução, contém o capítulo teórico, em que é apontado o arcabouço teórico-metodológico desta pesquisa, a Economia Política da Comunicação; o capítulo histórico, em que são apontados os principais eventos ligados ao desenvolvimento da internet no Brasil e no mundo; o capítulo empírico, que descreve a o processo de automação bancária no Brasil e problematiza as iniciativas do Bradesco no curso de desenvolvimento da internet. Os dois últimos capítulos são dedicados às considerações finais e às referências bibliográficas.

No próximo capítulo será delimitada a moldura teórica deste trabalho. O texto busca apresentar, de maneira panorâmica, os conceitos mais fundamentais do eixo teórico-metodológico da Economia Política da Comunicação (EPC). Nesta seção, também é traçado um diálogo entre as contribuições de César Bolaño, Ruy Sardinha Lopes, Manuel Castells, Dan Schiller e Robert McChesney, dentre outros autores, a respeito do surgimento das novas tecnologias da informação e da comunicação. Por fim, ainda no capítulo dois, é apresentado o atual debate acadêmico e político a respeito da neutralidade de rede e dos planos Zero Rating. O assunto será retomado no capítulo cinco, quando são devidamente apresentadas as duas iniciativas de internet grátis do Bradesco.

O capítulo três apresenta um panorama do desenvolvimento da internet, apontando os principais eventos históricos que forjaram a atual configuração da rede mundial de computadores. A primeira seção do texto trata do cenário da Guerra Fria ao começo dos anos 2000. Optou-se por elencar na segunda seção, em destacado, os fatos e eventos que particularizaram a gestação da internet no Brasil neste período. A última 
parte do capítulo, caracteriza, seguindo periodização proposta em Bolaño et al. (2007), o quarto estágio de desenvolvimento da internet, fase inaugurada após os anos 2000 que se estende até os dias atuais.

O capítulo seguinte busca iluminar o interesse dos bancos no desenvolvimento da internet. Antes disso, é apontado, em uma breve introdução, o funcionamento do Sistema Financeiro Nacional. Em seguida, o texto apresenta o processo de automação e informatização dos bancos no Brasil. Além das obras de Vera Dantas (1988), Marcos Dantas (1989), Diniz, Meirelles, Fonseca (2010), foram consultadas para a elaboração desta parte do texto 205 edições da revista Veja, de agosto de 1974 a março de 2016, que tratavam de temas relacionados a automação bancária e internet banking. $\mathrm{Na}$ segunda seção deste capítulo, são descritas as duas iniciativas de internet grátis lançadas pelo Bradesco em 1999 e 2014. Logo em seguida, na terceira seção do capítulo, são apresentadas outras ofertas de acesso patrocinado à internet oferecidas aos internautas brasileiros.

No capítulo cinco são apresentadas as considerações finais desta dissertação. Como se pretende demonstrar nas páginas que se seguem, a partir dos anos 2000, a internet passou a assumir uma centralidade no processo de informatização dos bancos no Brasil. A partir de 2010, com popularização do uso de celulares conectados à internet, também o mobile banking passou a ser uma fronteira a ser explorada pelos bancos.

A seção seguinte contém as referências bibliográficas do trabalho. Adicionalmente, como apêndice, o trabalho apresenta uma tabela com os principais fatos e eventos descritos nesta dissertação, que sintetizam a cronologia do desenvolvimento da internet e da automação e informatização dos bancos no Brasil. 


\section{CONSIDERAÇÕES TEÓRICO-METODOLÓGICAS}

Na primeira seção deste capítulo será apresentada a Economia Política da Comunicação (EPC), eixo teórico-metodológico em que se insere esta pesquisa. Além dos conceitos fundamentais e características gerais que descrevem os estudos e investigações da escola, é discutido o contexto social em que a EPC surgiu e as diferentes vertentes regionais de investigação. Ao final da seção, são apontadas algumas reflexões epistemológicas propostas por autores vinculados à EPC.

Como se pretende demonstrar nas páginas que se seguem, a escolha da Economia Política da Comunicação parte, não só do fato de o objeto de estudo desta dissertação ter afinidade com os principais debates propostos pela EPC, mas também pela possibilidade metodológica interdisciplinar que é oferecida, uma vez que, ao propor a inter-relação entre as comunicações, a cultura, a economia e a política (LOPES, 2008b), são fornecidos instrumentos mais acurados para a análise proposta neste trabalho. Conforme lembra Bolaño (2008),

As comunicações na contemporaneidade tornaram-se alvo de grandes investimentos, tanto do Estado quanto da iniciativa privada, os quais perceberam na mídia uma excelente ferramenta para a propaganda, a publicidade e a produção de mercadoria cultural. O grande capital encontra no setor um campo fértil de expansão, ocasionando a concentração e o fortalecimento dos conglomerados da Comunicação, para onde fluem capitais provenientes de setores poderosos, como as telecomunicações, ou o setor financeiro. Diante disso, torna-se necessária a EPC nos estudos do campo da Comunicação no Brasil, por esta ser um eixo cientifico explicativo não hegemônico que, ao comprometer-se com o rigor dos procedimentos, coloca-se em posição oposta à falsa despolitização do debate acadêmico, na medida em que defende o compromisso social da Ciência (BOLAÑO, 2008, p. 72).

$\mathrm{Na}$ segunda parte do capítulo, encontra-se a fundamentação teórica. Além de apresentar de maneira panorâmica o contexto histórico em que as novas tecnologias da informação e da comunicação surgiram, a seção busca estabelecer um diálogo entre as contribuições de César Bolaño, Ruy Sardinha Lopes, Manuel Castells, Dan Schiller e Robert McChesney, autores que vêm tratando de tal tema nos últimos anos a partir de diferentes perspectivas. 
A contextualização que se traça nesta seção visa apresentar ao leitor o amplo conjunto de transformações políticas, econômicas e sociais observados nas últimas cinco décadas, cenário em que se insere o desenvolvimento da internet. No capítulo três, o assunto será retomado destacando-se, entre outros aspectos, as inovações propriamente técnicas que permitiram a constituição da rede mundial de computadores.

A última parte do capítulo apresenta o atual debate a respeito da neutralidade de rede e da permissibilidade de planos Zero Rating e objetiva ampliar o entendimento a respeito das campanhas de internet grátis oferecidas pelo banco Bradesco a seus correntistas em 1999 e 2014, que serão apresentadas no capítulo quatro. O objetivo da seção não é aprofundar-se nas tecnicalidades jurídicas ${ }^{3}$ e zonas cinzentas que se apresentam em torno deste tema, mas enquadrar devidamente o atual debate político e regulatório em que se insere o desenvolvimento da internet.

\subsection{A Economia Política da Comunicação: fundamentos iniciais}

Segundo revisão didática apresentada em Vicent Mosco (2009), há duas importantes definições para a Economia Política da Comunicação. O primeiro enunciado aponta que a EPC pode ser entendida como o "o estudo das relações sociais, particularmente as relações de poder, que mutuamente constituem a produção, distribuição e consumo de recursos, incluindo os recursos de comunicação" (MOSCO, 2009, p. 2, tradução nossa). De acordo com o autor canadense, esta definição tem um "valor prático" ao apontar que a comunicação opera como um negócio e que, portanto, seus produtos comunicacionais fluem em uma cadeia produtiva, composta por produtores, distribuidores, comerciantes e consumidores (MOSCO, 2006).

Já em uma segunda definição "mais geral e ambiciosa", nas palavras do próprio autor, a EPC é entendida como "o estudo do controle e da sobrevivência na vida social" (MOSCO, 2009, p. 3, tradução nossa). Segundo Mosco, esta abordagem confere à Economia Política da Comunicação uma certa amplitude de sua análise, ao propor que seu estudo se voltaria tanto para os processos de organização interna dos grupos sociais

\footnotetext{
${ }^{3}$ Cf. RAMOS (2015a).
} 
que são, em geral, de ordem política, como para as atividades voltadas para a continuidade e reprodução social, que são, em sua maioria, de ordem econômica.

Em uma abordagem introdutória e, portanto, necessariamente abreviada, Simis e Lopes (2010) indicam na conceituação da EPC suas origens históricas. Segundo explicam esses autores, a Economia Política da Comunicação é o constructo teóricometodológico que, a partir do surgimento das indústrias de mídia no século $\mathrm{XX}$, aproxima as contribuições de Karl Marx do campo da Comunicação:

Se a Economia Política surge para explicar o modo de funcionamento do capitalismo, foi o aparecimento das indústrias da mídia no século $\mathrm{XX}$ - e seu papel na lógica de reprodução do estágio monopolista do capitalismo - que aproximou este campo disciplinar das comunicações. Desta forma, as contribuições de Adorno, Horkheimer, Walter Benjamim e demais colegas da chamada Escola de Frankfurt para o melhor entendimento das especificidades da produção cultural e sua relação com os processos econômicos e sociais mais amplos abriram uma frutífera e longa trajetória investigativa que (...) desembocaram na EPC (SIMIS; LOPES, 2010, p. 163).

Em consonância, Brittos (2008) argumenta que a EPC tem um legado marxiano como "matriz estruturante" e destaca:

A descoberta das leis dos fenômenos estudados é uma preocupação do pensamento marxista, o que passa pela análise das continuidades, rupturas e conexões, onde o homem e seu contexto exercem um papel central. Trata-se de um rumo distinto dos métodos próprios do pensamento neoclássico da chamada Economia, que imperam na academia e no mercado. A partir daí a EPC revela-se uma fonte inesgotável não só de respostas, mas também de questionamentos (BRITTOS, 2008a, p. 194-195).

Voltando às obras de Mosco (2009, 2006), que apresentam um panorama bastante esquemático a respeito da EPC, o autor sustenta que as investigações que partem da Economia Política da Comunicação apresentam um conjunto de quatro características fundamentais, independentemente das particularidades e diferenças de cada estudo. A primeira delas é a preocupação em entender as mudanças sociais e as transformações históricas. De acordo com o autor, essa qualidade, que já estava presente nos trabalhos de figuras fundantes da Economia Política, como Adam Smith e 
John Stuart Mill, e também na crítica de Karl Marx, é reformulada atualmente pelos pensadores da EPC a partir de uma questão fundamental: estaríamos entrando ou não em uma "Sociedade da informação"? Nas palavras do autor, trata-se de questionar:

A nossa sociedade configura um novo tipo de organização social, como foi o capitalismo, ou é apenas uma nova forma de capitalismo, talvez a ser chamado de capitalismo informacional? As forças da nova comunicação e das tecnologias da informação são tão revolucionárias que estariam causando uma reestruturação radical que levará à transformação ou até mesmo dissolução do capitalismo? (MOSCO, 2009, p. 3, tradução nossa).

A segunda característica apontada por Mosco como central aos estudos da EPC é o interesse em examinar a totalidade das relações sociais. Isto significa que as análises propostas por esta escola não se limitam a um aspecto da vida social, mas abarcam elementos econômicos, políticos, sociais e culturais da sociedade. Assim, os estudiosos da EPC buscam entender como todos esses aspectos influenciam, por exemplo, os sistemas de mídia, informação e entretenimento.

O compromisso com a filosofia moral é a terceira característica das investigações inseridas no campo EPC. Segundo Mosco, essa qualidade pode ser compreendida como o interesse tanto pelos valores que ajudam criar o comportamento social como pelos princípios morais que deveriam guiar os esforços para mudá-lo. Desta forma, "a Economia Política contemporânea tende a favorecer pontos de partida filosófico-morais que promovem a extensão da democracia a todos os aspectos da vida social" (MOSCO, 2006, p. 60, tradução nossa).

A práxis, última característica indicada por Mosco, diz respeito ao encontro entre o pensar e o agir. Trata-se de superar a ideia de que há uma clivagem entre a atividade intelectual e as ações de transformação e intervenção social. A EPC posiciona-se, desta forma, contra a "falsa despolitização do debate acadêmico" (BRITTOS, 2008, p. 194). Assim, os investigadores da Economia Política da Comunicação "têm persistentemente considerado a vida intelectual como uma forma de transformação social e a intervenção social como uma forma de conhecimento" (MOSCO, 1999, p. 100). 
Além das contribuições intelectuais predecessoras de Marx, Bolaño (2010) situa na trajetória de desenvolvimento da Economia Política da Comunicação a obra de Walter Benjamim (1936) sobre a reprodutibilidade da obra de arte como um dos marcos fundamentais da área. Em sua companhia, figura a obra de Adorno e Horkheimer (1947), "Dialética do Ilumunismo", definidora do conceito de indústria cultural, que representa, ainda segundo Bolaño, "o ponto máximo" da contribuição da Escola de Frankfurt à teoria da comunicação em geral (BOLAÑO, 2010, p. 35).

Ainda nesse exercício de identificar as contribuições fundadoras do campo, Bolaño (2010) confere destaque especial ao trabalho de Raymond Williams (1974) e sua influência fundamental não apenas na escola inglesa, mas também na francesa. Como explica o autor, ao particularizar aquilo que denominou de "sequência" ou "fluxo", a organização das indústrias do broadcasting (radiodifusão, como se costuma dizer no Brasil) que a Economia da Comunicação e da Cultura (ECC) francesa chamará de "cultura de onda" (culture de flot), a obra de Williams se inscreve adequadamente no rol de trabalhos seminais da ECC francesa. Além desta contribuição essencial para a construção da taxonomia das indústrias culturais que a tradição francesa faria anos mais tarde, o autor dedicou-se ainda a realizar estudos comparativos da história da radiodifusão no Reino Unido e nos Estados Unidos e de suas grades de programação (BOLAÑO, 2010, p. 36-40).

Indica-se, entre as obras predecessoras da EPC europeia, além da obra de Williams, os trabalhos de Murdock e Golding (1981), em que os autores se empenharam em explicar o papel prestado pela comunicação de massa no processo de estratificação social, por meio da reprodução das relações de classe, e de Garnham (1990) que, por sua vez, enfatizou a importância do papel econômico desempenhado pela mídia (BOLAÑO, 2010; BOLAÑO; MASTRINI; SIERRA, 2004, p. 49) ${ }^{4}$.

\footnotetext{
${ }^{4}$ Em Bolaño (2000a) é apresentada a escola francesa da economia da comunicação e da cultura, retomando, entre outras obras, as contribuições de Huet et al. (1978), Flichy (1980) e Miège et al. (1986). Como explica o autor, o primeiro trabalho do grupo da ECC francesa, "Capitalisme et industries culturelles", publicado ainda no ano de 1978, voltava-se ao estudo dos processos de produção e da valorização do capital investido no campo da cultura, entre outros pontos. Dois anos mais tarde, Flichy (1980), que se situava próximo aos economistas que formavam o principal grupo de pesquisa da França na área, propôs que há duas lógicas sociais que regem a produção cultural industrializada: a indústria de edição (composta pela produção literária, fonográfica e audiovisual) e a cultura da onda (integrada pelas indústrias de rádio, a televisão e a imprensa). Num desdobramento desta análise, Miège et al. (1986), na segunda grande contribuição da escola francesa, defendiam que há, na realidade, cinco lógicas sociais: a de edição de mercadorias culturais, a da cultura de onda, a da informação escrita, a da produção de
} 
Simis e Lopes (2010), elencam alguns dos autores que teriam exercido influência no desenvolvimento da Economia Política da Comunicação. De um lado estariam Paul Baran, Paul Sweezy, Dallas Smythe e Herbert Schiller, referências intelectuais da "escola" norte-americana e, do outro, da vertente europeia, estariam Nicholas Garnham, Peter Golding, Graham Murdock e, numa segunda geração de autores, Patrice Flichy e Bernard Miège. Como sintetizam, a contribuição teórica da primeira escola observa-se

Seja criticando as teorias que viam os meios de comunicação massivos como uma esfera de produção de ideologia e estratégias discursivas enfatizando o papel da mercadoria audiência (Smythe), seja ressaltando a função da publicidade como arma fundamental das estratégias competitivas das grandes empresas oligopolistas (Baran e Sweezy), ou ainda, como o trabalho de Herbert Schiller, estabelecendo os vínculos orgânicos entre os sistemas de comunicação e as operações do capital transnacionais [...] (SIMIS; LOPES, 2010, p. 163-164).

Uma apresentação mais detalhada de tais contribuições ${ }^{5}$, presente em Bolaño (2000a), se faz necessária - considerando que, conforme argumenta o autor, as análises de Baran e Sweezy (1966) de um lado e Smythe (1977), de outro, seriam duas grandes tradições segundo às quais os estudos marxistas sobre a função publicidade no processo de acumulação capitalista têm se organizado.

Como explica Bolaño (2000a), a contribuição de Baran e Sweezy propõe que a publicidade, ao lado de gastos militares, se configuraria como um "gasto de circulação", que não adicionaria valor à mercadoria. Com o processo de substituição da

programas informáticos e a da retransmissão do espetáculo ao vivo. Dado não ser este o escopo de interesse deste trabalho, não se faz necessário analisar em detalhes cada uma das contribuições da tradição francesa. Para um resgate aprofundado da ECC ver Bolaño 2000 (p. 161-221) e Bolaño 2010.

${ }^{5}$ Em Bolaño, Mastrini e Sierra (2004) é apresentado, em síntese, as principais contribuições de Smythe e Schiller aos estudos da Economia Política da Comunicação. Como explicam, as posições tomadas por esses dois autores no final da década de 1950 representaram alguns dos "desafios mais sérios" à pesquisa de comunicação de massa que vinha sendo desenvolvida dentro do quadro do behaviorismo. O mérito do trabalho do primeiro autor, prosseguem, consistiu-se no fato de ter se voltado à questão econômica, ao invés de focar-se na autonomia do aparelho ideológico do Estado, enquanto a obra de Schiller, centrada na análise da estrutura econômica internacional da mídia, desvelou aos leitores a relação entre o governo estadunidense, as grandes companhias de mídia e as corporações industriais e bancárias (BOLAÑO; MASTRINI; SIERRA, 2004, p. 49). Seguindo a diretiva do trabalho de Schiller, esta dissertação busca apresentar as afinidades entre o desenvolvimento da internet e a trajetória da automação e informatização dos bancos no Brasil. 
concorrência por preço por outras formas de concorrência, a publicidade teria se tornado um instrumento que as grandes empresas capitalistas dispõem em suas estratégias de diferenciação. Citando trechos dos autores, Bolaño sintetiza:

\begin{abstract}
$\mathrm{Na}$ verdade, as despesas totais de publicidade e outras despesas de promoção de vendas dividem-se, para Baran e Sweezy, em duas partes: de um lado, a que, mediante o aumento dos preços pagos pelo consumidor final, recai sobre os trabalhadores produtivos e, de outro, a que recai sobre os próprios capitalistas e trabalhadores improdutivos. A primeira parcela reduz o salário real na mesma proporção do aumento dos preços, aumentando de forma correspondente o excedente (a diferença entre a produção líquida total e os salários reais totais dos trabalhadores produtivos). Já a segunda parcela "não constitui um aumento do excedente, mas provoca sua redistribuição" em favor de quem "obtém suas rendas dos salários e lucros criados pela própria 'indústria' de vendas" (BOLAÑO, 2000a, p. 139).
\end{abstract}

Desta forma, ainda conforme Bolaño (2000a), no quadro interpretativo de Baran e Sweezy, "com a expansão do papel da publicidade, esta deixa de ser um 'simples adjutor da produção', ocorrendo uma 'transferência no centro de gravidade econômico da produção para as vendas"” (BOLAÑO, 2000a, p. 139-140).

Para fundamentar sua crítica à Baran e Sweezy, Bolaño se refere ao trabalho de Maria Arminda do Nascimento Arruda (1985) a respeito do capitalismo brasileiro. Em linhas gerais, segundo Arruda (1985), a compreensão dos dois primeiros autores contém um "grave equívoco" no plano de análise. Isso porque seriam os deslocamentos inter e intra-setoriais do capital, o avanço do capital constante em relação ao variável e o consequente aumento da produtividade do trabalho "os mecanismos primordiais da competição intercapitalista" e não os mecanismos de diferenciação por preço, "secundários à caracterização do capitalismo em qualquer de suas etapas" (ARRUDA, 1985, p. 33).

Em Bolaño (2000a) também é apresentado e devidamente criticada a obra de Dallas Smythe (1977). Em síntese, conforme é apontado em "Indústria cultural, informação e capitalismo", Smythe defendia, entre outras teses, que o setor de comunicações de massa produziria como mercadoria um público que, "ao aprender a comprar determinadas marcas de bens de consumo", prestaria uma espécie de serviço aos anunciantes (SMYTHE, 1977, p. 79). 
Em sua obra, Smythe também situa o desenvolvimento da publicidade comercial como condição à sobrevivência do capitalismo monopolista, quando a racionalização em grande escala e a preponderância da grande empresa capitalista fazem com que a publicidade seja utilizada para o manejo da demanda. Conforme explica Bolaño (2000a) a respeito deste argumento de Smythe,

Nessas novas condições, o capital se defronta aos indivíduos, enquanto trabalhadores e consumidores, de uma nova forma: de um lado desenvolve-se a administração científica do trabalho e, de outro, o consumo passa também a ser uma variável do planejamento da grande empresa. $\mathrm{O}$ aumento da racionalização se materializa, neste segundo caso, num controle de demanda que se processa também de modo qualitativamente distinto ao que caracterizava a situação anterior. Isto é, conforme exemplifica o autor [Smythe] não ocorre uma simples expansão da rede de vendedores de porta em porta, viajantes etc., como seria em princípio possível, mas algo radicalmente distinto: o desenvolvimento da publicidade comercial e a constituição de um complexo sistema de comunicação social, cujas funções, indispensáveis à sobrevivência do capitalismo monopolista [...] (BOLAÑO, 2000a, p. 146-147).

Analisando o conjunto das contribuições de Baran, Sweezy e Smythe, aqui brevemente descritas, Bolaño (2000a) argumenta que a publicidade é uma despesa necessária à realização da mercadoria e caracteriza-se, portanto, como uma "despesa de circulação especial":

A publicidade é, por um lado, uma indústria cultural que produz um produto cultural determinado e, por outro, uma indústria que, como o conjunto da indústria de transportes e comunicações, faz parte da infra-estrutura social necessária à realização das mercadorias e que acrescenta valor a estas últimas. Ora, essa dupla natureza que, insisto, não se limita à publicidade, mas que é intrínseca ao conjunto das indústrias culturais, só pode ser corretamente apreciada se entendermos que esses setores são duplamente produtivos justamente porque produzem sempre não uma, mas duas mercadorias [...] (BOLAÑO, 2000a, p. 146).

Adiante, Bolaño (2000a) retoma este debate, apontando que, na Indústria Cultural, o trabalho tem um duplo valor, cria duas mercadorias de uma só vez: o serviço cultural em si (o livro, programa, informação) e a audiência (BOLAÑO, 2000a, p. 222). Voltando-se mais à obra de Smythe, Bolaño argumenta que o autor teve o mérito de 
problematizar a mercadoria "público", mas passa ao largo, entre outros pontos, da relação dialética que se estabelece entre o mercado de bens culturais e o mercado de audiências, "deslocando o eixo da discussão da função propaganda para a função publicidade dos meios, sem perceber a relação contraditória que existe entre ambas as necessidades de reprodução do sistema” (BOLAÑO, 2000a, p. 148)

Ainda que a contribuição de Smythe tenha se iniciado com um curso de EPC ainda no final da década de 1940, é a partir de 1960 que a Economia Política da Comunicação começa de fato a se desenvolver (LOPES; SIMIS, 2010). As mudanças provocadas pelo modelo de economia fordista; o desenvolvimento da economia de consumo de massa; a expansão das funções do governo como produtor, distribuidor, consumidor e regulador da Comunicação; a onda de privatizações impulsionadas por regimes liberais; o processo de transnacionalização de grandes empresas; a Nova Ordem Mundial da Informação e Comunicação; e a possível emergência de uma "Sociedade da Informação" foram algumas das forças sociais que teriam colaborado para o amadurecimento da EPC a partir dos anos sessenta (MOSCO, 2009) ${ }^{7}$.

\footnotetext{
${ }^{6}$ Em "Indústria cultural, informação e capitalismo", Bolaño (2000a) explica que a Indústria Cultural realiza o trabalho de mediação simbólica entre o capital e o Estado, instâncias de poder, e as massas de consumidores e eleitores. Para tal, ela cumpre duas funções gerais no capitalismo avançado: propaganda e publicidade. Em linhas gerais, a primeira se relaciona com as funções ideológicas desempenhadas pela informação e a segunda, com sua dimensão econômica. Bolaño acrescenta a esse quadro de funcionalidades a função programa, "que vem a ser cumprida pela Indústria Cultural a partir do momento em que formas mais orgânicas, ligadas à cultura popular, de criação de significados, são deslocadas e apropriadas por ela" (BOLAÑO, 2000a, p. 241). Trata-se da função que confere à Indústria Cultural a capacidade de atrair a atenção do público.

${ }^{7}$ Mosco (2006) sugere que na segunda metade do século XX é possível identificar três diferentes ênfases regionais da EPC: a) a vertente norte-americana, influenciada pelas obras de Smythe e Schiller; b) a corrente europeia, que teve como contribuições fundamentais, além de Murdock e Golding e Garnham, a obra de Armand Mattelart; e c) e a vertente terceiro-mundista, desenvolvida por pensadores como Srinivas Melkote e Leslie Steeves, Bella Mody, Manjunath Pendakur e Yuezhi Zhao (MOSCO, 2006). Segundo o autor, a escola norte-americana, motivadas pelos estudos seminais de Smythe e Schiller, tem produzido investigações sobre o poder corporativo transnacional de empresas de mídia e sua relação com o Estado. Já as investigações europeias estariam preocupadas, ainda de acordo com Mosco (2006), em analisar a integração das empresas de comunicação e órgãos reguladores e a resistência das classes e de movimentos sociais à liberalização, comercialização e privatização das indústrias de comunicação e, num segundo grupo, mais próximo aos estudos de Mattelart, mirava, a luta de classes e no entendimento da comunicação como um dos principais recursos de resistência ao poder. Segundo o autor, a Economia Política da Comunicação em países de Terceiro Mundo se desenvolveu, por seu turno, de maneira bastante singular: inicialmente, os estudos eram uma resposta ao paradigma desenvolvimentista estadunidense, que entendia o crescimento dos media como um índice de desenvolvimento das nações. Os investigadores desta escola refutavam tal modelo questionando "em especial, o seu determinismo tecnológico e a omissão de praticamente todo o interesse nas relações de poder que condicionam os termos das relações entre as nações de Primeiro e Terceiro Mundo" (MOSCO, 1999, p. 104). Tal divisão revela-se limitada, sobretudo no que diz respeitos às chamadas vertentes europeia e "terceiro-mundista". Ao agrupar a tradição europeia em duas vertentes, influenciadas por Garnham e Golding e Murdock e,
} 
Para Brittos (2008a) há um relativo atraso no crescimento da Economia Política da Comunicação como fonte de elucidação na Europa. Segundo o autor, neste continente, a EPC toma corpo enquanto constructo teórico-metodológico "paulatinamente a partir dos anos 1980, quando os processos de privatização põem em relevo o papel econômico do principal meio, a televisão, um aspecto que já era dominante nos Estados Unidos e na maioria da América Latina" (BRITTOS, 2008a, p. 197).

Voltando-se para o cenário brasileiro particularmente, é considerada a obra fundante da Economia Política da Comunicação no Brasil o livro "Mercado brasileiro de televisão" $(1988)^{8}$, dissertação de mestrado do teórico César Bolaño em que é analisado o processo de oligopolização da TV brasileira (BRITTOS, 2008; SIMIS; LOPES, 2010). ${ }^{9}$

Como observa Bolaño (2008), ainda que a Economia Política nacional tenha se desenvolvido "sobre o terreno preparado pelas Teorias do Imperialismo ou da Dependência cultural", a escola representa "um recuo crítico" em relação a esses estudos, uma vez que os pesquisadores procuravam inspiração na crítica da Economia Política “e não nas derivações sociológicas do Materialismo histórico" (BOLAÑO, 2008, p. 63) $)^{10}$.

Institucionalmente, é a partir da década de 1990, que a EPC se fortaleceu na academia brasileira, com a criação de um Grupo de Trabalho da Economia Política da Comunicação na Sociedade Brasileira de Estudos Interdisciplinares da Comunicação

do outro lado, por Mattelart, Mosco negligencia em sua análise o trabalho desenvolvido pelos teóricos da ECC e também deixa escapar de sua lista dos autores influenciadores da EPC neste continente as contribuições de Pierre Bourdieu, "Produção da Crença" (1977), e de Jaques Atalli, "Ruídos" (1977) (BOLAÑO, 2010). Em relação ao que chama de EPC "terceiro-mundista", Mosco (1999) ignora por completo as contribuições o continente Latino Americano em sua análise - parte de tal desconhecimento pode ser explicada pelo fato de os pesquisadores latino-americanos vinculados à EPC terem se juntado aos quadros da IAMCR (International Association for Media and Communication Research) apenas no ano de 1992.

${ }^{8}$ Segundo Brittos (2008a), antes disso, em 1982, foi publicado no Brasil o livro "Televisão e Capitalismo no Brasil" que, embora tivesse diálogo com questões centrais da EPC e tenha desempenhado contribuição para o campo, tratava-se de "uma pesquisa com forte matriz sociológica e, em consonância com seu tempo histórico, baseada nas teorias da Dependência Cultural" (BRITTOS, 2008a, p. 198).

${ }^{9}$ Em busca de um marco inicial da EPC no país, Melo (2009) reconhece como "reflexões percursoras da Economia Política da Comunicação no Brasil" as obras de Barbosa Lima Sobrinho (1923) e Costa Rego (1929) que, ao apontarem a incursão do Jornalismo pela economia, teriam realizado um "contundente diagnóstico (...) da nossa imprensa periódica" (MELO, 2009, p. 18-19). Trata-se, no entanto, de uma periodização que não é seguida pela grande maioria dos estudiosos da área.

${ }^{10} \mathrm{Cf}$. BOLAÑO (2015). 
(INTERCOM) em 1992 e na Associação Latino-Americana de Pesquisadores da Comunicação (ALAIC) em 1995. Contribuiu ainda de maneira significativa para o crescimento da Economia Política da Comunicação no Brasil a criação da Rede de Economia Política das Tecnologias da Informação, da Comunicação e da Cultura (EPTIC) em 1999 (BRITTOS, 2008a).

Em um esforço de articulação internacional, foi criada em 2002 a União Latina de Economia Política da Informação, da Comunicação e da Cultura (ULEPICC), com representantes do Brasil, Espanha, Argentina, Moçambique, México, Canadá, Portugal, França, Chile e Angola ${ }^{11}$ (SIMIS; LOPES, 2010). No evento realizado no ano de 2001 em Buenos Aires, que antecedeu a criação da federação, o $1^{\circ}$ Encontro de Economia Política do Mercosul, foram definidas algumas das diretrizes que orientariam os pesquisadores da EPC latino-americana nos anos seguintes. Entre os objetivos do grupo está a produção de conhecimento crítico em contraposição aos estudos tecnocráticos e instrumentais do chamado "pensamento único" que, na visão dos investigadores reunidos em Buenos Aires, tornou-se cada vez mais dominante nas ciências da Comunicação:

A resistência à tendência hegemônica do pensamento único no campo das Ciências da Comunicação não pode desconhecer a Economia Política da Informação, da Comunicação e da Cultura, entendida como um conjunto de enfoques críticos e heterodoxos que se contrapõem ao chamado "mainstream". Nas associações nacionais e internacionais de Ciências da Comunicação, os grupos de Economia Política vêm assumindo um importante papel na organização de intelectuais desse campo dedicados a um tema marginalizado até muito pouco tempo. Como resultado, se criou um marco teórico próprio, interdisciplinar e pertinente para a compreensão da realidade atual, proporcionando um importante instrumento de análise para fundamentar a ação dos atores sociais não-hegemônicos no campo da comunicação. De sua parte, a escola latino-americana tem tido a capacidade de desenvolver um aporte teórico original e de incorporar a contribuição de autores anglo-saxões e europeus (UNIÓN LATINA DE ECONOMIA POLÍTICA DE LA INFORMACIÓN, LA COMUNICACIÍN Y LA CULTURA, 2001, tradução nossa).

\footnotetext{
${ }^{11}$ No site da seção brasileira da ULEPICC é possível acessar o Estatuto e o Regimento da federação: $<$ http://www.ulepicc.org.br/>. Acesso em: 20 nov. 2016.
} 
Ainda que EPC seja um campo de estudo relativamente novo, com pouco mais de meio século, alguns autores vinculados à escola já apresentam reflexões a respeito da necessidade de renovação de seus estudos. Para Mosco (2006), “a Economia Política da Comunicação necessita estar cimentada em uma epistemologia realista, inclusiva, constitutiva e crítica" (MOSCO, 2006, p. 65, tradução nossa), o que pressupõe: i) reconhecer a realidade a partir tanto de conceitos como práticas sociais; ii) rechaçar o essencialismo que reduz todas as práticas sociais a uma única explicação políticoeconômica; iii) enfocar a vida social como um conjunto de processos mutuamente constitutivos, que atuam uns sobre os outros em vários estados de formação e com uma direção e impacto que só podem ser compreendidos com investigação específica; iv) e, por fim, entender o conhecimento como produto de comparações com outros corpos de conhecimento e com valores sociais.

McChesney (2013), em uma reflexão semelhante a respeito da necessidade de atualização da EPC, propõe que esse paradigma teórico-metodológico é indispensável para entender o atual desenvolvimento da internet. Isso porque "a EPC se esforça em fornecer uma compreensão mais exata a respeito dos mercados de mídia e do verdadeiro papel do governo neste contexto" (MCCHESNEY, 2013, p. 64, tradução nossa). Para McChesney, tal quadro explicativo oferecido pela escola é resultado da soma de duas diferentes linhas de investigação empreendidas pelos pesquisadores da Economia Política da Comunicação. A primeira examina as instituições, os subsídios, a estrutura de mercado e as firmas que constituem um sistema de comunicação. Já a segunda linha de análise dedica-se ao papel fundamental desempenhado pelo governo no estabelecimento desse sistema. Em resumo, na avaliação do autor, a EPC "estuda e avalia como as políticas de comunicação foram debatidas e determinadas e tem um forte componente histórico ao olhar como essas políticas e os sistemas foram criados no passado" (MCCHESNEY, 2013, p. 64, tradução nossa).

Compartilhando a compreensão de Mosco a respeito da práxis da Economia Política da Comunicação, McChesney argumenta que os estudos da escola tendem a apontar para sistemas de mídia mais próximos de valores democráticos. Neste sentido, torna-se central para a EPC compreender a organização do conjunto de instituições midiáticas na sociedade. Isso significa, na visão do autor, lançar luz sobre as políticas públicas, estruturas, subsídios e instituições que são criadas para regular a mídia, uma 
vez que esse conjunto é "responsável pela lógica e natureza dos sistemas midiáticos" (MCCHESNEY, 2013, p. 65).

Bolaño, Mastrini e Sierra (2004) também oferecem reflexões a respeito dos atuais desafios que vive o campo da Economia Política da Comunicação, dois dos quais interessa destacar, considerando o que propõe esta dissertação. Em primeiro lugar, conforme argumentam os autores, é particularmente útil empreender análises genealógicas que reconstruam a história da formação dos objetos de conhecimento da EPC. Isso porque, dentre outros motivos elencados pelos autores, os campos de produção, circulação e acelerado consumo de bens culturais constituem o núcleo de controle e desenvolvimento na sociedade. Desta forma,

\begin{abstract}
Os problemas da economia política das comunicações não podem mais ser circunscritos na dimensão social das comunicações. Os processos socioculturais devem ser concebidos e conectados com a produção industrial de mentes e corpos, e com o trabalho humano (no sentido antropológico). Devem estar também ligados ao problema estratégico do conhecimento na valorização e reprodução da vida social e humana e dos sistemas de dominação (BOLAÑO; MASTRINI; SIERRA, 2004, p. 55, tradução nossa).
\end{abstract}

Outro desafio epistemológico apontado pelos autores é a necessidade dos trabalhos desenvolvidos no âmbito da EPC se posicionarem e terem o comprometimento com os movimentos sociais de sua região, o que uniria o sentido da investigação com a visão e desejo de emancipar tais grupos.

Conforme esta seção buscou destacar, a Economia Política da Comunicação revelou-se um eixo teórico-metodológico promissor para a realização da investigação proposta nesta dissertação. Isso porque, ao permitir deslocamentos interdisciplinares, que combinam elementos explicativos advindos da Comunicação, da Sociologia, da História e da Economia, enriquece a análise a respeito do objeto de estudo, a relação entre o desenvolvimento da internet e da automação e informatização bancária no Brasil. O viés crítico e a práxis presente nas investigações da EPC permitem ainda que a compreensão a respeito da presença da iniciativa privada no setor de internet, especialmente ao adotar práticas de acesso patrocinado, como o Bradesco fez em duas oportunidades distintas, não se aproximasse de análises celebratórias ou ingênuas. 


\subsection{Fundamentação teórica: a reestruturação do capitalismo e o desenvolvimento das TIC a partir década de 1970}

Para melhor endereçar as questões teóricas suscitadas nesta dissertação, é necessário compreender o contexto histórico em que se desenvolveram as tecnologias de informação e de comunicação (TIC) no curso histórico do capitalismo. Esse assunto é caro a investigadores vinculados à Economia Política que, num quadro amplo, têm avaliado o processo de mundialização capitalista em consonância com as transformações pelas quais têm passado as forças produtivas como Chesnais (1996), Dawson e Foster (1998), Haug (2003), Fitzpatrick (2002), Dean (2005) e Negri e Vercellone (2008), conforme revisão proposta em Paraná (2016). O tema também é objeto de estudo de autores da Economia Política da Comunicação, entre eles, César Bolaño (2000a, 2000b, 2007), Ruy Sardinha Lopes (2008a) e, no cenário internacional, Dan Schiller (2002) e Robert McChesney (2013).

O ponto de partida para essa análise é a crise que o sistema Capitalista Monopolista $^{12}$ passa a enfrentar a partir da década de 1970. Antes disso, como lembra Bolaño (2000b), no período pós-guerra, houve uma trajetória ascendente inédita no desenvolvimento do sistema capitalista, ancorado por um Estado intervencionista que, por meio de políticas do Welfare State (em português, o "Estado do bem-estar social"), garantiram o crescimento econômico com distribuição de renda a grandes parcelas da população dos principais países capitalistas. Esse período ficou conhecido como "Trinta Gloriosos" e se estendeu, aproximadamente, de 1945 a $1975^{13}$.

A partir do final dos anos 1960, um conjunto de fatores de ordem econômica, política e social levou ao desmantelamento dos padrões de crescimento observados até

\footnotetext{
${ }^{12}$ A passagem do Capitalismo Concorrencial a sua fase Monopolista se deu na virada do século XIX. Em síntese, como explica Bolaño (2000b), no primeiro estágio, havia um sistema de mercado composto por capitais individuais, regidos por um modo de auto-regulação do próprio mercado, que determinava os níveis de preços e de salários. Ao Estado, notadamente não intervencionista, era necessário garantir as condições necessárias ao processo de acumulação do capital. Com o surgimento da grande empresa capitalista, se dá a inauguração do capitalismo monopolista, em que, seguindo a tendência à concentração e centralização, os mercados passam a se organizar em oligopólios e o Estado assume um papel intervencionista, contrapondo-se aos interesses dos grandes capitais e dos sindicatos.

${ }^{13}$ Foi também nesse período que se desenvolveram os grandes meios de comunicação de massa, veículos de publicidade comercial e da propaganda política (BOLAÑO, 2000b) e houve o aparecimento, no campo epistemológico, das Ciências da Informação e da Comunicação (BOLAÑO, 2015, p. 58-59).
} 
então. Segundo Lopes (2008a), teriam contribuído para tal cenário o fim dos acordos de Bretton Woods (que, entre outros elementos, determinavam a paridade ouro-dólar), a derrota militar dos Estados Unidos no Vietnã, entre outros aspectos agravados pela crise do preço do petróleo do começo da década de 1970. A tudo isso se somava a uma onda de descontentamento social na Europa e nos Estados Unidos, e em outras partes do mundo.

Bolaño (2000b) acrescenta outros fatores ao quadro iniciado nos anos sessenta:

A crise se deve ao esgotamento do potencial dinâmico dos setores que puxaram a expansão (automotivo, eletroeletrônico e da construção civil) e das contradições internas de uma economia de endividamento crescente, que gerou o descolamento entre as órbitas financeira e produtiva, responsável pelos sobressaltos que passaram a acontecer recorrentemente no sistema a partir da crise do endividamento externo dos países do Terceiro Mundo, em 1982, e cuja última expressão foi justamente a crise brasileira do final de 1998 (BOLAÑO, 2000b, p. 4).

Ainda que tenham fundamental importância para compreensão do atual cenário macroeconômico, não cabe no escopo deste texto avançar na discussão a respeito do conjunto de fatores que levaram à crise do final da década de 1960 e seu aprofundamento nos anos seguintes. O que interessa especialmente ao desenvolvimento desta dissertação é o papel assumidos pelas tecnologias da informação e da comunicação a partir deste contexto.

Lopes (2008a), em estudo bastante detalhado sobre o assunto, retroage às raízes históricas do desenvolvimento tecnológico em território estadunidense para compreender o papel das TIC na reestruturação capitalista a partir da década de 1970. Segundo o autor, o uso do telégrafo, associado, num segundo momento, ao desenvolvimento da telefonia e radiofonia e à expansão da malha ferroviária, sempre teve importância fundamental para o mundo dos negócios naquele país, de dimensões continentais. A acumulação capitalista teria se preocupado, desde o final do século XIX e princípio do século XX, com o desenvolvimento de meios transporte, comunicação e controle militar eficientes e métodos gerenciais e organizacionais que atendessem às necessidades do capitalismo continental dos Estados Unidos. 
Foi a partir da Primeira Guerra Mundial, que os sistemas de comunicações passaram a ser notados, de fato, pelos países do globo como instrumentos de importância militar e geopolítica. No contexto do segundo confronto mundial, vinte anos mais tarde, o comprometimento dos setores bélicos com o desenvolvimento de pesquisas científicas se aprofundou.

Citando análise realizada por Mattelart (2006), Lopes (2008a) destaca em seu quadro interpretativo a formação dos chamados think tanks sobretudo nos Estados Unidos que, por meio de contratos e parcerias estabelecidas entre os centros militares e os de pesquisa científica, patrocinaram o desenvolvimento de diversas inovações tecnológicas, tais como decifradores de códigos, detonadores remotos, o primeiro computador programável e o transitor.

Nas palavras de Mattelart (2006), tais reservatórios de ideias seriam “um local estratégico na produção de um saber orientado para o planejamento da sociedade do futuro" (p. 59). Como explica o autor:

Seguindo o esquema de cooperação permanente entre civis e militares, setor privado e setor púbico, [...] insere-se um elo original na produção do saber-operação: o think tank ou reservatório de ideias. Em seu início, essa nova instituição de pesquisa recicla engenheiros e cientistas desmobilizados. O primeiro, e mais famoso, dos think tanks é fundado em 1946 pela Força Aérea americana em Santa Monica, na Califórnia: a Rand (Research and Development Corporation). Esse reservatório de ideias, que também se tornará um centro de ensino superior, é o berço da análise de sistemas (system analysis), das metodologias de custo-benefício (cost-effectiveness), do sistema de planejamento, programação e orçamento (Planning, Programming and Budgeting System ou PPBS) e das aplicações da teoria dos jogos. Como fizeram durante o conflito mundial, especialistas das ciências sociais, economistas, matemáticos, engenheiros e físicos eram incitados a partilhar seus conhecimentos (MATTELART, 2006, p. 58-59).

Lopes (2008a) argumenta, então, que com o patrocínio desses thinks tanks foram desenvolvidas as novas tecnologias da informação e da comunicação (TIC), buscando assegurar não apenas um maior domínio militar, mas também sistemas de controle e comando eficientes da produção, cada vez mais internacionalizada e diversificada. Em síntese, 
As cooperações constantes entre civis e militares, setor privado e setor público, postas em funcionamento por esse tipo de reservatório de ideias, se revelaram estratégicas não só para a conquista militar, mas para o próprio desenvolvimento capitalista, ainda mais num momento em que reconversão eletrônica vinculada cada vez mais a acumulação à produção de novos conhecimentos capazes de acelerar a inovação tecnológica. Isso implicará tanto a elevação dos custos de pesquisas e desenvolvimento quanto o surgimento de complexos mecanismos (tecnológicos e ideológicos) de apropriação privadas do conhecimento gerado cada vez mais coletivamente (LOPES, 2008a, p. 42).

Após situar esse quadro histórico do surgimento das tecnologias da informação e da comunicação, o autor destaca em sua análise dois momentos distintos do desenvolvimento tecnológico, num sentido mais amplo, no cenário internacional. Segundo Lopes (2008a), após a Segunda Guerra Mundial, com o cenário de poder desenhado no globo, uma estrutura de poder militar e tecnológico unipolar apoiava o projeto de hegemonia dos Estados Unidos. Observou-se naquele período, a corrida espacial, ancorada na constituição de um complexo sistema de telecomunicações e acirrada pelo lançamento do satélite russo Sputinik, e a formação da Arpanet, "a rede das redes", como se verá no capítulo a seguir.

Num segundo momento, com o abrandamento da Guerra Fria e dissolução gradual de tensões militares entre as duas principais potências bélicas, Estados Unidos e União Soviética, houve uma transição da lógica de política tecnológica em vigor até então. Com a reconfiguração geopolítica, o estamento militar deixou de ser a único demandante e incentivador da indústria de alta tecnologia e deu-se início a uma fase de investimentos mercantis que buscam, entre outros objetivos, dar suporte à reestruturação capitalista (LOPES, 2008a, p. 44-45).

É a partir de então que as TIC assumem uma "centralidade econômica" ao permitir que as empresas tivessem uma atuação cada vez mais transnacional ${ }^{14}$. Como argumenta Lopes (2008a), aliadas à política neoliberal que passou a se desenvolver a partir da década de oitenta, as tecnologias da informação e da comunicação teriam dado

\footnotetext{
${ }^{14}$ Ainda segundo Lopes, o setor financeiro, que a partir da década de 1970 ocupa o cerne do regime de acumulação, "foi um dos primeiros a reconhecer as grandes vantagens advindas das TIC que permitiam aumentos exponenciais nos 'movimentos de capitais sem pátria"' (LOPES, 2008a, p. 47). Para mais sobre as afinidades entre o desenvolvimento das Tecnologias da Informação e Comunicação e o processo de financeirização da economia mundial ver Paraná (2016).
} 
"grande impulso ao movimento de deslocalização produtiva e financeira" (LOPES, 2008a, p. 49).

Compreensão semelhante tem Bolaño (2000b) a respeito do papel desempenhado pelas TIC no processo de reestruturação capitalista. Para esse autor, tais tecnologias tiveram proeminência nos esforços para retomada do desenvolvimento a partir de 1980. Avançando neste debate, Bolaño apresenta o conjunto de mudanças estruturais observadas:

Sob a batuta do neoliberalismo, iniciar-se-á um processo de grande envergadura de desregulamentação, privatização e questionamento do Estado do bem estar social, que pretende abrir espaço para a acumulação privada, revertendo a tendência de crise, o que, diga-se de passagem, efetivamente não ocorre, mantendo-se a taxa de acumulação extremamente deprimida durante todo o longo período, de mais de quinze, quase vinte anos de implantação sistemática dos programas vinculados àquela ideologia hegemônica nas principais instâncias de poder econômico internacional. Seria importante apontar a diferença fundamental entre o significado dessas políticas para os países do primeiro e do terceiro mundos [...]. Vale dizer apenas que, grosso modo, enquanto nos primeiros a desregulamentação e as eventuais privatizações estão ligadas a uma estratégia nacional de posicionamento frente à concorrência internacional em setores chave para o futuro do capitalismo, nos outros, trata-se de alienar o patrimônio nacional, sem nenhuma contrapartida aparente, sob a pressão do endividamento externo e dos programas de estabilização ditados pelo Fundo Monetário Internacional (BOLAÑO, 2000b, p. 4)

Tanto na perspectiva interpretativa de Bolaño (2000b) como de Lopes (2008a) tem importância a chamada $3^{\mathrm{a}}$ Revolução Industrial. Trata-se, conforme define o primeiro autor, do movimento de subsunção do trabalho intelectual no capital, permitida justamente pelo desenvolvimento de tecnologias informacionais. Ela se diferencia da Revolução Industrial original e da Segunda Revolução Industrial em que, de maneira simplificada, a subsunção real do trabalho avançou por meio da máquinaferramenta e da produção de máquinas por meio de máquinas, respectivamente (BOLAÑO, 2000b).

Tal constructo teórico tem importância para a compreensão do objeto desta dissertação uma vez que o componente tecnológico envolvido na $3^{\mathrm{a}}$ Revolução 
Industrial, as TIC "atingem o mundo de trabalho, as formas de coordenação inter e intra-empresariais e institucionais e os modos de consumo de milhões de pessoas [...], constituindo-se em fator de importância crucial para as grandes transformações por que o mundo vem passando neste final de século" (BOLAÑO, 2000b, p.8). Considerando essa tese, as ofertas de internet grátis do Bradesco, de 1999 e 2014, apresentam-se, cada qual à sua maneira, como exemplos do atual processo de informatização geral da sociedade.

Voltando-se para as contribuições feitas no cenário internacional a respeito deste assunto, um dos autores que tem se destacado no estudo do surgimento das novas tecnologias da informação e de comunicação e a organização da sociedade nas últimas décadas é Manuel Castells (1999, 2003, 2012, 2015). O ponto de partida da abordagem desenvolvida pelo intelectual é o que define como "Sociedade em rede". Esse conceito refere-se, segundo o autor, em linhas gerais, a uma nova forma de organização da sociedade que foi influenciada por transformações sociais, tecnológicas, econômicas e culturais, que ocorreram de forma global a partir dos anos 1970 (CASTELLS, 1999).

Sistematizando estudos de casos que realizou em vários continentes, Castells argumenta que as estruturas organizativas em rede se tornaram elementos constitutivos de diversas dimensões da vida humana. Assim, de acordo com o quadro interpretativo do autor, estariam organizadas em rede as forças produtivas do mercado de trabalho, a cultura interativa mediada pela internet, a estrutura do Estado e até mesmo os movimentos sociais (CASTELLS, 1999, 2012).

Castells apresenta no conceito de "empresa em rede" $(1999,2001)$ sua reflexão a respeito da difusão da internet no mundo dos negócios. Segundo o autor, a "empresa em rede" é caracterizada por uma geometria de cooperação e competição entre firmas que se constitui em torno de projetos empresariais específicos. Não se trata da organização interna de uma empresa ou da simples união de várias delas, mas de um novo paradigma organizacional. É, em síntese,

Aquela forma específica de empresa cujo sistema de meios é constituído pela intersecção de segmentos de sistemas autônomos de objetivos. Assim, os componentes da rede tanto são autônomos quanto dependentes em relação à rede e podem ser uma parte de outras redes e, portanto, de outros sistemas de meios destinados a outros objetivos (CASTELLS, 1999, v.1, p. 232). 
Para Castells, esse tipo de formato organizacional é um fenômeno distintivo da “economia informacional global”. Conforme explica o autor, a crescente importância dos fluxos de informação, dos desenvolvimentos científicos e tecnológicos na produção reconfiguraram o contexto econômico de tal forma que a configuração de "empresas em rede" tornou-se a resposta ideal para lidar com os ambientes operacionais em constante mudança.

Partindo de um amplo estudo de caso de trajetórias organizacionais em diferentes continentes, do Leste Asiático ao cenário norte-americano, Castells (1999) observa que a organização em rede de algumas empresas analisadas teria precedido até mesmo o surgimento de importantes tecnologias da informação. É o caso, como lembra o autor, do sistema chamado kan-ban, introduzido pela montadora de carros Toyota já em 1948. Por meio de fichas padronizadas e distribuídas em vários pontos da fábrica, fornecedores e funcionários da empresa trocavam informações a respeito da produção.

Isso levou Castells a concluir que as "empresas em rede" não se constituíram como consequências automáticas da transformação tecnológica. Porém, na avaliação do autor, não teria sido possível manejar a complexidade das estruturas em rede que se desenhavam sem as ferramentas de informação e de comunicação baseadas na microeletrônica. O autor aponta, então, uma certa afinidade entre esse formato organizacional e as novas tecnologias da informação. Para ele, foi devido à necessidade de utilização de redes pelas novas organizações [...] que os computadores pessoais e as redes de computadores foram amplamente difundidos" (CASTELLS, 1999, v.1, p. 230). Por outro lado, foi a própria disponibilidade de tais ferramentas de comunicação e informação que possibilitou a difusão da integração em rede em resposta às necessidades de flexibilidade organizacional e desempenho empresarial.

Com a generalização da internet, das Intranets e das Extranets, com base na banda larga, nas redes de comunicação rápida, as empresas, grandes e pequenas, se relacionavam com facilidade, entre si e com os clientes, num padrão interativo e flexível. Em consequência disso, todos estavam tecnologicamente capacitados a adotar a forma organizacional em rede, contanto que a empresa estivesse capacitada para a inovação administrativa (CASTELLS, 1999, v.1, p. 231). 
Embora não ignore completamente o aspecto econômico no desenvolvimento das redes de informação e comunicação e da internet, o autor faz desse elemento um fator secundário em sua construção analítica. Para Castells, as diferentes trajetórias e culturas empresariais que compõem o conceito de "empresas em rede", amplamente descritos em sua obra (1999), são características da nova estrutura social que se desenha desde os anos 1970, a "Sociedade em rede".

Neste sentido, há no trato teórico do autor um relativo distanciamento entre a influência de grandes empresas e do poder econômico no desenvolvimento das novas tecnologias da informação e da comunicação. Ainda que se utilizem largamente das TIC, as empresas são caracterizadas, por Castells, muito mais como beneficiárias das inovações tecnológicas do que arquitetas das mesmas.

Como já foi apontado por outros autores tais como Coutinho (2003) e Lopes (2008a) há nessa trilha teórica traços de um certo determinismo tecnológico. Em linhas gerais, conforme sinalizam esses dois autores, Castells confere às tecnologias uma importância por vezes demasiadamente acentuada na conformação da estrutura organizacional e econômica da sociedade.

Para Coutinho (2003), o conjunto de interpretações que propõe a criação e a disseminação da tecnologia seguindo uma trajetória linear desconsidera a construção social e um contexto mais amplo. Voltando-se especificamente para a obra de Castells, aponta que o próprio autor procurou escapar de críticas a seu determinismo tecnológico ao indicar em artigos posteriores à trilogia “A era da informação" (1999) que sua análise busca analisar não a Sociedade da Informação, mas o modo informacional de desenvolvimento (COUTINHO, 2003, p. 88)

Em consonância com Coutinho (2003), Lopes (2008a) argumenta que "várias outras críticas podem ser feitas a essa tentativa de centrar a caracterização do modo de produção capitalista numa produtividade tecnologicamente determinada" (LOPES, 2008a, p. 118). Entre outros aspectos, o autor argumenta que Castells esquece que a mais-valia do capital depende, além da incorporação de novas tecnologias, das formas de subsunção do trabalho no capital. Para Lopes, Castells também negligencia o fato de que as novas tecnologias, além de em alguns casos se traduzir em aumento de produção, operam na construção de formas de organização e criação de novos mercados com altas barreiras de entrada. Em síntese, 
Apesar de Castells tentar, em sua trilogia A era da informação, ir além do determinismo tecnológico, analisando o surgimento do "novo mundo" a partir da convergência de três processos independentes gestados a partir do fim da década de 1960 e início dos anos 1970: a revolução das TIC, a crise do modo de regulação fordista e do estatismo e o florescimento de movimentos sociais e culturais como o feminismo, o ambientalismo e a defesa dos direitos humanos, sua abordagem é, em última instância, tecnologicamente determinada. [...] Tal postura teórica o levará, em nosso entendimento, tanto a uma má compreensão das relações entre tecnologia e sociedade quanto a uma visão equivocada do capitalismo na atualidade, bem como do papel da informação e do conhecimento do processo produtivo (LOPES, 2008a, p. 116-117).

Por fim, não há no quadro interpretativo de Castells uma indicação clara do que ele toma por "empresa" e "informação". O primeiro conceito não foi devidamente definido nas obras revisadas nesta dissertação, o que dificulta uma problematização mais avançada a respeito da "empresa em rede". Quanto ao segundo termo, também falta ao autor um recorrido conceitual mais robusto, como fez Bolaño em "Indústria Cultural, Informação e Capitalismo" (2000a) ${ }^{15}$.

A perspectiva teórica de Castells também é contestada por Dan Schiller, que sustenta que a utilização da rede pelas empresas, dentro delas e nas relações entre si, é que constituiu o verdadeiro fulcro do desenvolvimento da internet (2002). Segundo Schiller, o avanço das tecnologias da informação e comunicação, que começaram a se desenvolver com maior velocidade nos anos 1970, foi amplamente patrocinado pelo poder econômico, representado por grandes empresas, que viam na informatização e no

\footnotetext{
${ }^{15}$ Em "Indústria Cultural, informação e capitalismo", Bolaño (2000a) busca construir um conceito não idealista de informação que se adeque às determinações gerais do modo de produção capitalista. Em seu exercício metodológico derivacionista, o autor apresenta, em primeiro lugar, a informação na circulação mercantil, quando é aparência que mascara o modo de produção. Bolaño toma como exemplo dois proprietários privados que se defrontam no mercado para compra e venda de mercadorias. Em síntese, o autor explica que ao vendedor e ao comprador fica dada a possibilidade de manipulação da informação. Num segundo momento, prossegue Bolaño, o da produção capitalista, a informação deixa de ser puramente máscara, ideologia, para se tornar poder. Nas palavras do autor: "a comunicação que se realiza no processo produtivo de tipo capitalista é uma comunicação hierarquizada, burocratizada, compatível com a estrutura de poder na fábrica. [...] A informação adquire, assim, sua forma especificamente capitalista, referida ao processo de trabalho: informação unidirecional, organizada de acordo com as necessidades de acumulação do capital" (BOLAÑO, 2000a, p. 41-42). É num terceiro momento, o da multiplicidade de capitais em concorrência, que a informação se torna mercadoria e adquire "sua forma capitalista mais adequada para o cumprimento daquelas funções (ideologia e poder) determinadas em níveis mais abstratos de análise" (BOLAÑO, 2000b, p. 6).
} 
surgimento das TIC uma forma de reestruturar a produção e dar fluidez aos negócios, que se tornavam cada vez mais integrados globalmente.

Foi com o objetivo de sufocar outra crise econômica - a do início dos anos 1970 - que as classes dirigentes apoderaram-se dos novos sistemas de cálculo e comunicação como instrumentos de "ajuste espaço-temporal", de acordo com a expressão de David Harvey. Tratava-se, antes de mais nada, de reatar com os lucros, canalizando os capitais para um setor capaz de engendrar um forte crescimento. Investimentos maciços irrigaram então as tecnologias da informação e comunicação (conhecidas pela sigla TIC), plantando no senso comum a ideia de uma transição sorridente em direção a uma nova idade de ouro, batizada de "sociedade da informação" (SCHILLER, 2009, p.1).

Schiller (2002) busca demonstrar, então, que a internet e o sistema mais alargado de comunicação com o qual ela se entrelaça operam como instrumentos do capitalismo digital e permitem a transnacionalização da atividade econômica. Em sua análise, centrada na Economia Política, ganha ênfase especial a escalada de investimentos de grandes firmas capitalistas em tecnologias da informação e, em um segundo momento, na internet; e a reestruturação dos sistemas de telecomunicações, desencadeada pela crescente dependência das empresas em relação aos sistemas de rede.

O processo de reorganização de empresas em torno de redes de informática envolveu, segundo Schiller, toda a economia. Analisando o cenário estadunidense dos anos 1980 ao começo dos anos 1990, o autor detalha os vultosos valores dispendidos em sistemas de informação e comunicação integrada por empresas dos mais variados setores de atuação - de empresas de tecnologia de ponta (como a Boeing, a General Eletric, a petroleira American Petroleum Institute) às redes de supermercados e varejistas (Wal-Mart e 7-Eleven). "As maiores empresas de todos os ramos de atividade econômica procuravam construir redes integradas de computadores para gestão das atividades nucleares de produção, distribuição, marketing e administração" (SCHILLER, 2002, p. 34).

Quando a internet passou a ter uso comercial, em meados dos anos 1990, ela potencializou a capacidade de as empresas trocarem informações. Os diversos setores da economia, que já vinham investindo em redes informáticas integradas de gestão 
empresarial, passaram a investir em aplicações comerciais da internet como uma nova infraestrutura descentralizada de informação global (SCHILLER, 2002, p. 44). É neste sentido que o autor argumenta que, muito embora a rede mundial de computadores tenha surgido como um projeto militar em 1969, chamado de Arpanet, como se verá a seguir, sua arrancada a partir da segunda metade dos anos noventa foi patrocinada pela "América empresarial".

A crescente dependência das empresas a sistemas de comunicação e à internet demandou uma modernização radical dos sistemas de telecomunicações. Para Schiller (2002) O setor, que até então era sustentado por monopólios estatais, sujeito a diferentes arranjos operacionais em cada país, foi obrigado a sair da letargia e responder à crescente importância do ciberespaço como plataforma de infraestrutura operacional de negócios. Ainda que a tumultuada transformação neste setor tenha sido desencadeada através de uma série de transformações políticas e econômicas que foram acontecendo nos Estados Unidos a partir da década de 1950, conforme demonstra Schiller, seu ponto crítico se deu nos anos 1980, quando a política neoliberal de reforma das telecomunicações tomou dezenas de países. Segundo dados do autor, entre 1984 e 1999 , o valor das privatizações no setor de telecomunicações atingiu US\$ 224 bilhões (SCHILLER, 2003).

Analisando as transformações no sistema de telecomunicações em diversos países do mundo, Schiller (2002) avalia que o processo se deu por meio de duas características fundamentais: a instalação do sistema de redes de computadores em uma magnitude nunca vista e o abandono por políticos de todo o mundo dos princípios de serviço público em favor de normas advindas da iniciativa privada ou demandadas diretamente pelo mercado. Na visão do autor, longe de objetivos sociais, o desenvolvimento da rede conformou-se de modo a facilitar o acesso de transnacionais aos mercados locais, uma necessidade fundamental do capitalismo de nosso tempo, o capitalismo digital ${ }^{16}$.

\footnotetext{
16 "Capitalismo digital" é o título do principal livro de Dan Schiller. O termo foi criado no final da década de 1990, em resposta ao que autor chamou de "triunfalismo da Nova Economia" (SCHILLER, 2011). $\mathrm{Na}$ visão de Schiller, a internet seria uma espécie de catalisador da transição política e econômica entre duas épocas, em direção ao que ele chama de "capitalismo digital". Para o autor, as TIC são o pivô de uma nova fase do sistema capitalista e se integram ao domínio que a economia exerce sobre a sociedade e a cultura.
} 
Aproxima-se desta perspectiva o quadro interpretativo traçado por Robert McChesney (2013). Contrapondo-se às abordagens "celebratórias" e às perspectivas “céticas" a respeito da internet, o autor posiciona-se no campo da Economia Política da Comunicação ao propor um estudo sobre o desenvolvimento da rede a partir da análise do sistema capitalista, mais precisamente sobre a forma como o capitalismo molda a internet e a sociedade. Para McChesney, a busca pelo lucro, o comercialismo, o marketing e a publicidade são fundamentais para entender a evolução da rede mundial de computadores.

Em Digital Disconnect (2013), tem destaque o processo de privatização da internet que ocorreu no ano de 1995, como será visto a seguir, quando o governo estadunidense cedeu o controle da espinha dorsal da internet à época, a NSFNET, a agentes privados. Segundo o autor, tal mudança estrutural ocorreu sem nenhum debate público, sem que fossem discutidas quais implicações a comercialização da internet poderia trazer. A rede, que nos seus primeiros vinte anos havia se desenvolvido como um projeto não apenas não comercial, mas anti-comercial, tornou-se, na visão de McChesney, um preeminente setor capitalista a partir dos anos 1990.

Segundo o autor, quatro fatores explicam o triunfo da privatização da internet sem que houvesse contestação pública. O primeiro deles é a cultura política dos anos 1990, que estava, na visão de McChesney, muito mais voltada para os propósitos capitalistas do que para as noções de prestação de serviço público ou regulação, reflexo do fortalecimento de políticas neoliberais, que pregavam a defesa de livres mercados e a mínima interferência do Estado na economia. Nesse contexto, "as noções de bens públicos e regulamentação de interesse público eram suspeitas, se não ridicularizadas" (MCCHESNEY, 2013, p. 105). Conforme aponta o autor:

Qualquer coisa que interferisse na expansão capitalista era considerada algo economicamente ruim ou carregado ideologicamente, proposto por um grupo caloteiro com "interesses especiais" que não atendia as expectativas no mundo da competição do livre-mercado e procurava proteção do submundo corrupto da regulação governamental e da burocracia. Esse credo levou a desregulação econômica e à privatização da atividade de vários setores antes públicos (MCCHESNEY, 2013, p. 106, tradução nossa). 
Associado a isso está o processo de formulação de políticas públicas que, a partir da década de 1990, é notadamente marcado pelo interesse de grandes corporações. Analisando particularmente o cenário estadunidense, McChesney afirma que tanto o Federal Communications Comission ${ }^{17}$ como o Congresso dos Estados Unidos estariam "dedicados a fazer as firmas dominantes maiores e mais lucrativas" (MCCHESNEY, 2013, p. 92, tradução nossa). Para o autor, soma-se a esse cenário, a baixa fiscalização e participação da sociedade civil nos processos de distribuição de concessões de radiodifusão, de direitos autorais e, até mesmo, de subsídios fiscais. Para McChesney, a internet foi privatizada em meados da década de 1990 sob essas mesmas condições.

O terceiro fator apontado em Digital Disconnect é a bolha especulativa da internet. Como será visto em mais detalhes no próximo capítulo, tal termo se refere ao fenômeno de forte aquecimento no mercado de ações de empresas de tecnologia e informática entre 1995 e 2000. Para McChesney, a economia baseada na indústria da internet foi considerada, de maneira equivocada, a solução para os problemas que o capitalismo enfrentava nos anos 1990. A mídia teria exercido um papel central na supervalorização das "empresas.com” ao retratar os novos executivos como os grandes visionários da geração. Desta forma, a bolha da internet "fez as políticas que promoviam o desenvolvimento comercial do ciberespaço parecerem não apenas apropriadas, mas brilhantes" (2013, p. 108, tradução nossa).

O último fator determinante para a privatização da internet é a ausência de um conjunto coerente de políticas públicas que determinasse a natureza da rede mundial de computadores no começo dos anos 1990. Segundo McChesney, a única preocupação que havia naquela época era prevenir uma possível censura explícita do governo à liberdade de expressão na internet. "As implicações da privatização de 1994-1995 não estavam claras" (MCCHESNEY, 2013, p. 105, tradução nossa). Para o autor, os governos e formuladores de política pública não tiveram condições de antecipar, nos

\footnotetext{
${ }^{17}$ O FCC, na sigla em inglês, é a agência federal responsável pela regulação interestadual e internacional dos serviços de radiodifusão e das telecomunicações dos Estados Unidos. Trata-se de uma agência independente, supervisionada pelo Congresso estadunidense. O FCC é dirigido por cinco comissários escolhidos pelo presidente dos EUA e confirmados pelo Senado. A agência é a principal autoridade dos EUA no que se refere à legislação, regulação e inovação tecnológica relativas a Comunicações.
} 
anos 1990, todas as transformações políticas e tecnológicas por quais a internet passaria nos anos seguintes.

McChesney argumenta, então, que, a partir do processo de privatização e comercialização, a internet foi submetida a uma lógica capitalista de acumulação que é "hostil” ao potencial democrático da comunicação digital. Nas palavras do autor:

A tremenda promessa de revolução digital tem se comprometido pela apropriação e desenvolvimento capitalista. No grande conflito entre a abertura e um sistema fechado de lucro corporativo, as forças do capital triunfaram sempre que algo importava para elas. A internet foi sujeita ao processo de acumulação de capital, que tem uma lógica própria clara, hostil a grande parte do potencial democrático da comunicação digital. O que parecia ser uma esfera pública crescentemente aberta, longe do mundo das trocas de mercadorias, parece estar se transformando em uma esfera privada crescentemente fechada, proprietária, até mesmo num mercado de concorrência monopolística (MCCHESNEY, 2013, p. 97, tradução nossa)

Tudo somado, é possível identificar, por meio da leitura desses cinco autores, chaves analíticas centrais para a análise que se propõe nesta dissertação.

Lopes (2008a) e Bolaño (2000b) compreendem o desenvolvimento das tecnologias da informação e da comunicação na esteira de acontecimentos desencadeados a partir do final da década de 1960. Os dois autores consideram, ao introduzirem em suas obras o conceito de $3^{\text {a }}$ Revolução Industrial, o processo de subsunção do trabalho intelectual no capital no atual processo de informatização geral da sociedade.

Ao elaborar o conceito de "empresas em rede", Castells desenha uma importante ligação entre uma dimensão da nova estrutura social, a "Sociedade em rede", com as tecnologias da informação e da comunicação. Embora não confira às empresas um papel preponderante no desenvolvimento das TIC, entende que a organização empresarial que despontou a partir dos anos 1970 e se consolidou nos anos seguintes foi um estímulo importante para a difusão da internet na sociedade.

Já na análise de Schiller, torna-se patente o interesse de grandes empresas e corporações na utilização de redes de comunicação e informação como plataforma para otimizar e transnacionalizar a produção, em um contexto histórico de reestruturação do 
capitalismo. Essa perspectiva interpretativa confere um peso maior ao poder econômico no desenvolvimento de novas tecnologias.

Por fim, McChesney centraliza em sua análise o processo de privatização da internet, o que teria provocado, em sua visão, mudanças estruturais na rede mundial de computadores que inviabilizaram seu desenvolvimento a partir de valores democráticos. A reorganização da internet por meio da lógica comercial torna-se, desta forma, um elemento interpretativo indispensável para a análise proposta com este trabalho.

\subsection{Marco Civil da Internet e os conceitos de neutralidade de rede e Zero Rating}

Conforme foi demonstrado a partir de distintas posições do quadro teórico de Castells, McChesney, Schiller, Bolaño e Lopes, o desenvolvimento das tecnologias da informação e da comunicação desempenhou fundamental importância na reestruturação e reconfiguração das grandes empresas transnacionais, em especial, a partir da década de 1970. Tal cenário não foi diferente para os grandes bancos e instituições financeiras, como se verá em detalhes no capítulo quatro, em que a automação bancária e a conexão em rede são usadas como instrumentos estratégicos na atuação dos bancos em nível local e internacional, tanto em atividades de atacado como nas de atendimento personalizado a seus clientes.

Antes de avançarmos no desenvolvimento da automação bancária no Brasil e na análise das campanhas de acesso gratuito à internet oferecidas pelo Bradesco a seus correntistas em 1999 e 2014 - pontos de especial interesse para esta dissertação por representarem intersecções importante entre as trajetórias da internet e do processo de informatização dos bancos no país, cumpre destacar alguns dos atuais debates mobilizados pelo Marco Civil da Internet, lei ${ }^{0}$ 12.965/2014, que estabelece princípios, garantias, direitos e deveres para o uso da internet no Brasil.

Busca-se, nos apontamentos realizados nas páginas que se seguem, apresentar ao leitor o estado da arte $^{18} \mathrm{em}$ que se insere a mais recente oferta de internet grátis do

\footnotetext{
${ }^{18}$ Cumpre destacar neste ponto, apenas a título de contextualização, a importante análise a respeito da economia digital que pode ser feita desde os debates da "lógica de clube" da Economia da Comunicação e da Cultura da França. Tradicionalmente a literatura francesa distingue três distintas lógicas sociais que regem a produção cultural industrializada: a "Indústria de Edição" (composta pela produção literária,
} 
Bradesco, o “Acesso Gratuito ao Bradesco Celular”. Nos capítulos seguintes, o assunto será retomado para que seja possível elucidar a importância que o desenvolvimento da internet em determinada direção tem para os bancos e de que forma essas mesmas instituições tencionam a legislação para que seus interesses sejam atendidos - seja por meio de lobby e iniciativas políticas indiretas, como o financiamento de campanhas políticas, ou por ações comerciais que desafiam diretamente e abertamente a legislação do Marco Civil da Internet.

A discussão a respeito de "internet grátis" tomou recentemente o centro do debate público e acadêmico com a crescente oferta de planos de Tarifa Zero (Zero Rating). Tal termo refere-se, de maneira simplificada, aos planos de acesso à internet móvel em que operadoras de telecomunicação e provedores de aplicação fornecem navegação gratuita a determinado tipo de conteúdo online (AGÊNCIA NACIONAL DE TELECOMUNICAÇÕES, 2015). Esse tipo de estratégia comercial já foi banido por órgãos reguladores de diversos países, tais como Holanda, Eslovênia, Noruega e Canadá (MARSDEN, 2015b), que consideraram o tráfego gratuito prejudicial à

fonográfica e audiovisual), a "Indústria de Onda" (indústrias do rádio e televisão) e a "Imprensa" (jornal e revista), que ocuparia posição intermediária entre as duas primeiras classificações. Tais lógicas se diferenciam-se, entre outros fatores, pelas cadeias econômicas e mercados que a caracterizam e a forma por meio da qual são realizadas as vendas e obtidas receitas. Em síntese, no modelo editorial é levado ao mercado determinado bem cultural, que pode ser reproduzido industrialmente. O consumo de tal bem é individual, sua difusão é descontínua e irregular e o financiamento é dado pelo preço pago pelo consumidor final. Por seu turno, na cultura de onda, o consumo é semi-individual, a difusão é contínua e o financiamento pode advir de subsídios, taxas ou vendas de espaços publicitários. Finalmente, a imprensa apresenta consumo semi-individual, tal qual a cultura de onda; uma difusão descontínua, mas irregular; e tem uma modalidade de financiamento diversificada - parte dos recursos vem de valores pagos pelos consumidores e outra parte de anunciantes (HERSCOVICI, 2009). Considerando o avanço da digitalização e processos decorrentes de convergência tecnológica, Tremblay (1997) acrescentou ao conjunto de taxonomias a "lógica do clube". Conforme argumenta Tremblay, as técnicas de distribuição e comunicação bidirecional e interativa na oferta de produtos culturais desestruturaram a lógica da onda, sedimentada nos progressos técnicos dos produtos audiovisuais dos primórdios da radiodifusão. $\mathrm{O}$ modelo do clube se configura, segundo Tremblay, quando há oferta de produtos e de programação (da lógica editorial e de onda, respectivamente), mercantilização direta (com venda de produtos e serviços online) e indireta (por meio dos processos que envolvem a venda de audiência) e financiamento igualmente híbrido - pago por usuários ou obtidos indiretamente por meio, por exemplo, da venda de espaços publicitários (HERSCOVICI, 2009; BOLAÑO et al., 2012). Em Herscovici (2009) são apresentadas importantes reflexões a respeito da pertinência do modelo de Tremblay para analisar a economia das redes digitais. Isso porque, conforme argumenta, a lógica do clube oferece corretamente os elementos de análise do que seria uma "primeira geração da internet", caracterizada pelo acesso via telefônica em que portais e servidores tinham papel destacado, ao passo que os usuários finais, em função dos dados a que tinham acesso, construíam sua própria programação. Segundo o autor, no entanto, numa "segunda geração da internet" a lógica do clube não se provaria mais tão adequada para explicar o funcionamento da rede. Herscovici propõe que, nesta fase, com o avanço do uso da banda larga e serviços gratuitos aos usuários, o desenvolvimento da economia não estaria mais ancorado na distribuição de bens privados, mas públicos, o que apontaria para uma nova lógica. 
neutralidade de rede (net neutrality). Neste sentido, para problematizar a mais recente oferta internet patrocinada oferecida pelo Bradesco, o "Acesso Gratuito ao Bradesco Celular", torna-se necessário apresentar os dois conceitos.

O termo "neutralidade de rede", no âmbito da internet, refere-se, em linhas gerais, ao tratamento não discriminatório às diversas informações que trafegam nas redes físicas de telecomunicações. Em teoria, de acordo com esse princípio, os controladores de serviços de telecomunicações, que oferecem telefonia e banda larga fixa ou móvel aos usuários, não podem intervir no fluxo de dados, retardando ou acelerando datagramas (pacote de dados) devido a sua natureza, conteúdo, tamanho, origem ou destino (RAMOS, 2015a). A neutralidade de rede garante, desta forma, que os consumidores recebam em seus aparelhos a velocidade de conexão e aos pacotes de dados que foram contratados junto aos provedores de acesso independentemente do uso que virão a fazer da internet, como, por exemplo, assistir um filme ou ouvir uma música, usar uma rede social ou enviar uma foto para outro internauta (SILVA, 2012).

Barbosa (2015) aponta que o conceito de neutralidade de rede é mais antigo e mais amplo do que a internet. Segundo o autor, o termo pode ser aplicado a diversos outros contextos, como a infraestrutura de rede de transportes e de energia elétrica. $\mathrm{Wu}$ (2006) explica, neste sentido, que o debate a respeito da "não discriminação" estaria ligado ao conceito de commom carriage datado do século XIX. Tal termo refere-se a empresa ou indivíduo que possui a obrigação de transportar informações, pessoas ou produtos e, por prestarem serviço de interesse público, estariam proibidos de dar tratamento preferencial ou discriminatório no exercício de suas atividades, conforme se firmou o entendimento jurisprudencial estadunidense (RAMOS, 2015a, p. 27).

Ramos (2015a) sugere que há três diferentes formas de os provedores de acesso exercerem controle do fluxo de comunicação em suas redes: a discriminação por bloqueio (ocorre quando há restrição completa a determinadas aplicações); por velocidade (quando há redução ou aumento de velocidade a determinado tipo de aplicação); e, por fim, por preço (que ocorre com a cobrança ou redução de tarifas adicionais para acessar determinado conteúdo). Segundo o autor, os planos de Tarifa Zero, por oferecerem gratuidade no acesso a alguns aplicativos, se enquadrariam neste último tipo de discriminação de dados.

No cenário acadêmico, conforme observa Barbosa (2015), as abordagens a 
respeito da neutralidade se dividem em dois grandes grupos. Há uma vertente de pesquisadores alinhada com o professor estadunidense Tim $\mathrm{Wu}$, primeiro pesquisador a usar o termo em 2003, que defende a aplicação do princípio. Esses estudiosos argumentam que o tratamento igualitário aos dados, independente do volume, origem e destino, é essencial para a manutenção da liberdade de comunicação e garantia de um ambiente inovador para o desenvolvimento de aplicações na internet. Isso porque, na visão desse grupo, com a neutralidade não haveria incentivos para o desenvolvimento, produção ou consumo de determinados tipos de conteúdos ou serviços em detrimento de outros (BARBOSA, 2015, p. 13). Também se insere na moldura argumentativa deste grupo a visão de que a arquitetura da internet alça os provedores de acesso à posição de gatekeepers $^{19}$ da rede (RAMOS, 2015a, p. 33)

Do outro lado estão os acadêmicos que entendem que a neutralidade de rede é um conceito utópico e descontextualizado das condições que dão sustentação à internet e seu desenvolvimento. Entre esses pesquisadores, o que mais se destaca na crítica à neutralidade é Christopher Yoo, professor de Direito, Comunicação e Ciência da Computação e Informação da Universidade da Pensilvânia (EUA). Na visão de Yoo, o gerenciamento do tráfego de dados na rede, ao criar diferentes combinações de preço e velocidade, a depender do conteúdo consumido pelos usuários finais, permitiria que um número maior de pessoas se conectasse à internet (BARBOSA, 2015, p. 14). Tal grupo também defende que a neutralidade de rede fere o princípio da livre-iniciativa e viola os direitos de propriedade das operadoras de telecomunicação sobre sua infraestrutura (RAMOS, 2015a, p. 32)

Em um “mapa de conflitos” sugerido em Ramos (2015a) há, ao menos, três diferentes grupos de interesses nesse debate. Em primeiro lugar, as empresas de telecomunicação provedoras de acesso à internet que entendem que a neutralidade é

\footnotetext{
${ }^{19} \mathrm{O}$ conceito de gatekeeper surgiu a partir de uma pesquisa sobre mudanças de hábitos alimentares de grupos sociais em 1947. Conduzida pelo psicólogo alemão Kurt Lewin, a investigação sugeria que, para chegar à mesa do indivíduo, o alimento enfrentava "zonas-filtros" da coleta ao preparo culinário. Isto é, para que o alimento pudesse ser consumido por um indivíduo, ele precisa passar por vários "porteiros" ou "cancelas" que, inseridos em suas próprias relações sociais, decidiam se o alimento deveria passar ou não para a próxima etapa do canal de alimentação. De acordo com Lewin, "A constelação das forças antes e depois da zona-filtro é decididamente diferente, de modo que a passagem ou bloco da unidade através de todo o canal depende, em grande parte, do que acontece na zona-filtro. Isso ocorre não apenas com os canais de alimentação, mas também com a sequência de uma informação por meio dos canais de comunicação num grupo" (LEWIN, 1947, p. 145).
} 
prejudicial, uma vez que "diminui os instrumentos de mercado disponíveis para controle da oferta e da demanda e pode potencialmente reduzir lucros, ganhos de eficiência na rede e incentivos à inovação no setor" (RAMOS, 2015a, p. 36-37).

O segundo grupo de interesse do debate é composto pelos provedores de aplicação, empresas que entregam conteúdos e aplicações aos usuários finais. De acordo com Ramos (2015a), esse grupo estaria dividido em duas partes. Há, de um lado, os grandes provedores de aplicações, para os quais a neutralidade, ainda que dificultasse a capacidade de manter posições hegemônicas no mercado, traria redução de custos transacionais com provedores de acesso, que não poderiam exigir pagamentos extras para entregar o conteúdo aos internautas. Do outro lado estariam os pequenos provedores que, com a não discriminação de pacote de dados, poderiam contar com a manutenção de baixas barreiras de entrada no mercado no que se refere à infraestrutura (RAMOS, 2015a, p. 38-39).

Por fim, o terceiro grupo que compõe o mapa de conflitos a respeito da neutralidade é composto por usuários, os consumidores finais da internet, nos termos de Ramos. Segundo o autor, com um regime de neutralidade de rede tal grupo poderia ser beneficiado na medida em que haveria maior diversidade de conteúdo na rede, maior autonomia e liberdade de expressão na internet. Mas, ao mesmo tempo, Ramos adverte que os usuários "heavy-users", que consomem um maior volume de dados, poderiam ser prejudicados com elevação de preços de acesso (RAMOS, 2015a, p. 39).

Ainda que o debate esteja longe de um consenso a respeito das vantagens ou desvantagens de uma rede neutra, diversos países já positivaram a neutralidade em seus arcabouços regulatórios. A primeira nação a incorporar a neutralidade de rede em suas normas foi o Chile (AGÊNCIA NACIONAL DE TELECOMUNICAÇÕES, 2015). Ainda no ano de 2010, a Lei n 20.453 de 2010 acrescentou à Lei Geral de Telecomunicações chilena (18.168 de $\left.1982^{20}\right)$, dispositivos que preveem regras e deveres às concessionárias de serviço de telecomunicações, entre elas a impossibilidade de discriminarem pacotes de dados que trafegam em suas redes.

\footnotetext{
${ }^{20}$ A Lei Geral das Telecomunicações Chilena e os dispositivos acrescentados após a sanção da Lei 20.453 , de 10 de dezembro de 2010 , estão disponíveis em <http://www.leychile.cl/Navegar?idNorma=29591> Acesso em: 17 out. 2015.
} 
Como aponta Ramos (2015a), no ano seguinte, em 2011, foram aprovadas regras gerais de neutralidade de rede no Peru e na Colômbia. No primeiro país, a Lei n ${ }^{\circ}$ 29.904/2011 e seu decreto regulamentador, sancionado em 2013, estabeleceram vedações aos provedores de acesso à internet que não podem realizar interferências no tráfego ou discriminar a utilização de conteúdos e aplicações da internet em função de origem, natureza ou propriedades. Na Colômbia, a Resolução $\mathrm{n}^{0} 3.502$ estabelece que os provedores daquele país estão proibidos de realizar bloqueios de conteúdo, aplicação ou serviços que não sejam previstos por lei ou ordem judicial. A regra colombiana ainda estabelece as hipóteses em que se justificam a discriminação e gerenciamento de tráfego.

Em 2012, a Holanda somou-se aos três países latino-americanos e tornou-se o primeiro país da Europa a aprovar normas a respeito da neutralidade de rede. Ainda no início da tramitação da legislação, em junho de 2011, os representantes da Câmara Baixa do Parlamento Holandês já haviam entendido, por maioria, que os prestadores de telecomunicações que atuam naquele país, tais como a KPN, Vodafone e T-Mobile, não poderiam bloquear ou cobrar por serviços como Skype ou Whatsapp (NET..., 2011). Pelos termos da lei atualmente em vigor no país, os prestadores de serviço de acesso à internet podem adotar práticas que minimizem os efeitos de congestionamento de tráfego na internet e que preservem a segurança e integridade da rede, mas estão proibidos de bloquear ou reduzir a velocidade de serviços ou aplicações da Rede (AGÊNCIA NACIONAL DE TELECOMUNICAÇÕES, 2015).

No mesmo ano, a Eslovênia dedicou um capítulo exclusivo para neutralidade de rede em sua nova Lei de Comunicações Eletrônicas e, em 2014, Israel acrescentou um aditivo em sua Lei de Comunicações para tratar do assunto. No primeiro país, os provedores podem adotar práticas de discriminação no tráfego de dados para evitar congestão e preservar a segurança da rede, evitar comunicações não desejadas e por determinação judicial. No segundo país, as exceções à neutralidade são autorizadas pela entidade reguladora israelense, que estabelece as hipóteses de gerenciamento razoável do tráfego (RAMOS, 2015a, p. 59-60).

No Canadá, está em vigor desde 2009 um documento que dispõe sobre gerenciamento de tráfego de internet (Internet Traffic Managemente Practices of 
Internet Service Providers) ${ }^{21}$, baseado em quatro critérios: (i) transparência; (ii) inovação; (iii) clareza sobre prática; e (iv) neutralidade competitiva. O texto publicado pela Comissão Canadense de Rádio-Televisão e Telecomunicações (CRTT), regulador canadense, exige, entre outras determinações, que os provedores informem aos usuários quando há gerenciamento de tráfego e qual tipo de tráfego (aplicação ou protocolo, por exemplo) está sujeito à administração. "Essas políticas são vistas como instrumentos básicos de neutralidade de rede no país" (AGÊNCIA NACIONAL DE TELECOMUNICAÇÕES, 2015, p. 16).

Até setembro de 2014, ano em que foi sancionado no Brasil o Marco Civil da Internet, como se verá em detalhes a seguir, o debate regulatório a respeito da neutralidade de rede estava presente em ao menos duas dezenas de países, de acordo com o mapa a seguir elaborado pela ONG Acess Now $^{22}$. A figura 1, apresentada abaixo, organiza os regimes regulatórios dos países em três grupos: a) "Hard law", onde há leis e regulamentos específicos vigentes; b) "Soft law", para países em que as empresas de telecomunicação ou governos promulgaram acordos ou diretrizes não vinculativas sobre o assunto; e c) "Proposals/Under Review", onde havia, até aquele momento, propostas de regulação em andamento ou revisão.

${ }^{21} \mathrm{O}$ conjunto de políticas de regulação e as decisões da CRTT encontram-se disponíveis em <http://www.crtc.gc.ca/eng/archive/2009/2009-657.htm>. Acesso em: 3 dez. 2016.

${ }^{22}$ Além de neutralidade de rede, a ONG Acess Now trata de temas como privacidade, liberdade de expressão e segurança digital. O mapa apresentado nesta seção pode ser visualizado em < https://www.accessnow.org/today-is-the-internet-slowdown/>. Acesso em: $1^{\circ} \mathrm{dez} .2016$. 


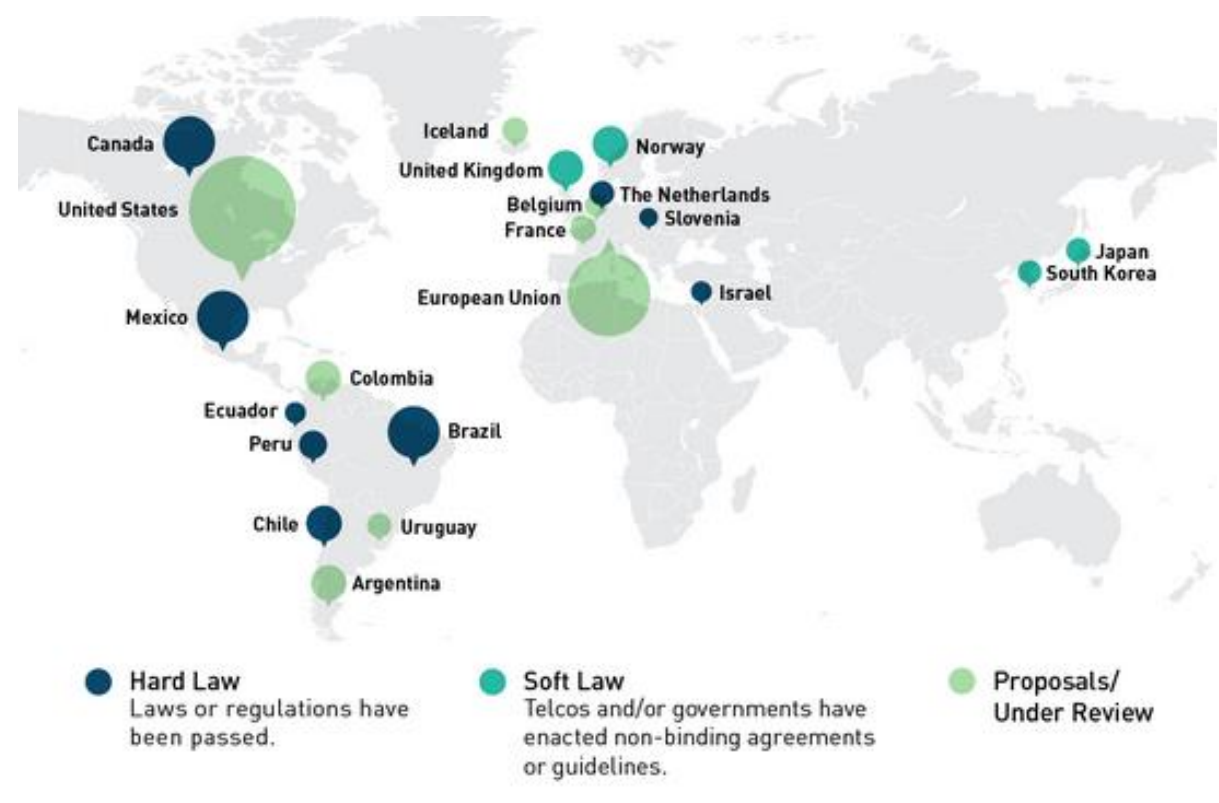

Figura 1 - Mapa das regulações sobre neutralidade da rede no mundo Fonte: ONG Acess Now

A título de contextualização, antes de apresentar a Lei n ${ }^{\circ} 12.965$, de 23 de abril de 2014, e o atual debate a respeito da neutralidade de rede no Brasil, cumpre atualizar na disposição deste mapa a situação regulatória nos Estados Unidos. Naquele país foram implantadas pela Federal Communications Comission (FCC), no primeiro semestre de 2016, normas de neutralidade de rede. Pelo texto em vigor, a banda larga, fixa e móvel, dos Estados Unidos não deve sofrer bloqueios, estrangulamentos ou priorização (DO AMARAL, 2015b). Em menos de um ano, operadoras móveis estadunidenses e provedoras de internet já entraram na justiça para questionar tal norma (DO AMARAL, 2016b).

No Brasil, a neutralidade de rede foi tratada na Lei $\mathrm{n}^{\circ} 12.965$, sancionada em 23 de abril de 2014, conhecida como Marco Civil da Internet ${ }^{23}$. Tal norma determinou que a neutralidade é um dos oito princípios que disciplinam o uso da rede mundial de computadores no país. O termo foi definido no caput do artigo nono daquela lei, que determina que "o responsável pela transmissão, comutação ou roteamento tem o dever

\footnotetext{
${ }^{23}$ Como aponta Santarém (2010) o projeto colaborativo de discussão e formulação de um marco civil da internet foi lançado ainda em outubro de 2009. Segundo o autor, tratava-se de uma resposta do governo federal diante de um impasse legislativo da lei de cibercrimes.
} 
de tratar de forma isonômica quaisquer pacotes de dados, sem distinção por conteúdo, origem e destino, serviço, terminal ou aplicação".

O parágrafo primeiro desse mesmo artigo prevê, no entanto, que o princípio da neutralidade não é um valor absoluto e que a discriminação ou degradação do tráfego poderá ocorrer, mas somente se isso decorrer de "priorização de serviços de emergências" e de "requisitos técnicos indispensáveis à prestação adequada dos serviços e aplicações". As exceções ao princípio da neutralidade, previstas, mas não determinadas pelo Marco Civil, seriam regulamentadas por meio de decreto presidencial, depois de serem apresentadas as recomendações do Comitê Gestor da Internet $^{24}$ (CGI.br) e da Agência Nacional de Telecomunicações (Anatel).

Para recolher posições de representante das empresas, organizações civis e governamentais, pesquisadores do assunto e cidadãos a respeito da neutralidade de rede, CGI.br, Anatel, e o Ministério da Justiça realizaram consultas públicas entre dezembro de 2014 e maio de 2015. Os questionamentos foram sistematizados em grandes eixos temáticos conforme está demonstrado na tabela 1 :

Tabela 1 - Consultas públicas a respeito da neutralidade de rede

\begin{tabular}{llcc}
\hline Órgão & Eixos temáticos & $\begin{array}{l}\text { Período da } \\
\text { Consulta } \\
\text { Pública }\end{array}$ & $\begin{array}{l}\text { Total de } \\
\text { participações }\end{array}$ \\
\hline CGI.br $^{25}$ & - Definições técnicas e de termos relevantes ao & $19 / 12 / 2014$ & 176 \\
& Marco Civil da Internet; & a 20/02/2015 & \\
& - Neutralidade de Rede; & & \\
& - Proteção aos Registros, aos Dados Pessoais e & & \\
& às Comunicações Privadas; & & \\
& - Guarda de Registros de Conexão; & & \\
& - Guarda de Registros de Acesso a Aplicações de & & \\
& Internet na Provisão de Aplicações; & & \\
& - Outros aspectos e considerações & & \\
Ministério da $^{\text {Justiçáa }}{ }^{\mathbf{2 6}}$ & - Neutralidade de rede & 28/01/2015 & \\
\hline
\end{tabular}

${ }^{24}$ Criado pelo decreto $\mathrm{n}^{\circ} 4.829$, de 3 de setembro de /2003, o Comitê Gestor da Internet no Brasil tem como atribuição legal estabelecer as diretrizes estratégicas relacionadas ao uso e desenvolvimento da internet no país. O órgão é formado por integrantes do governo, especialistas em internet, além de representantes da comunidade científica e tecnológica, do setor empresarial e do terceiro setor.

25 Os documentos e contribuições da consulta do CGI.br estão disponíveis em <http://marcocivil.cgi.br/contribuicoes/ >. Acesso em: 3 dez. 2015.

${ }^{26}$ A consulta pública do Ministério da Justiça foi realizada por meio do portal "Pensando o Direito", mantido pela Secretaria de Assuntos Legislativos do órgão. No dia 27 de janeiro de 2016, foi iniciada a segunda fase do debate a respeito da regulamentação do Marco Civil da Internet, em que os internautas puderam deixar suas contribuições na minuta de decreto elaborada pelo Ministério da Justiça. Todos os 


\begin{tabular}{|c|c|c|c|}
\hline & $\begin{array}{l}\text { - Guarda de registros } \\
\text { - Outros temas e considerações }\end{array}$ & & \\
\hline Anatel $^{27}$ & $\begin{array}{l}\text { - Prestação adequada de serviços e aplicações; } \\
\text { - Relações entre os agentes envolvidos; } \\
\text { - Modelos de negócio; } \\
\text { - Comunicações de Emergência; } \\
\text { - Bloqueio de Conteúdo a pedido do usuário; } \\
\text { - Outras considerações. }\end{array}$ & $\begin{array}{l}31 / 03 / 2015 \\
\text { a } 19 / 04 / 2015\end{array}$ & 147 \\
\hline
\end{tabular}

Fonte: CGI.br, Ministério da Justiça e Anatel; elaborada pela autora

Um dos temas que mobilizou o debate nessas consultas públicas foi justamente a permissibilidade de planos Zero Rating. Como mencionado anteriormente, o termo se refere a estratégias comerciais de prestadoras de serviço de telecomunicação e de provedores de aplicação que elegem determinado conteúdo ou aplicativo específico para ser acessado gratuitamente, sem que o tráfego desta navegação seja descontado do plano de internet do usuário (AGÊNCIA NACIONAL DE TELECOMUNICAÇÕES, 2015). Esse tipo de prática comercial ganhou popularidade em países em desenvolvimento desde o começo dos anos 2010 (RAMOS, 2015a). No Brasil, os planos de Zero Rating existem desde antes de 2014, quando o Marco Civil foi sancionado pela presidente Dilma Rousseff (MARSEN, 2015b).

No relatório que acompanha a consulta pública a respeito da regulamentação do Marco Civil da Internet, a Anate ${ }^{28}$ definiu as quatro práticas comuns de Zero Rating: (i) a prestadora de serviço de telecomunicação seleciona uma aplicação específica para que o tráfego gerado pelo acesso a essa aplicação não seja cobrado do usuário; (ii) a prestadora isenta o usuário da cobrança de dados para aplicações de interesse público e sem fins comerciais; (iii) o provedor de aplicação e conteúdo paga diretamente à prestadora pelo tráfego gerado por seus usuários (acesso patrocinado); e (iv) quando há

documentos produzidos pelo órgão estão disponíveis em: <http://pensando.mj.gov.br/marcocivil/>. Acesso em: 17 nov. 2016.

27 Todos os documentos da Consulta da Anatel estão disponíveis em <http://www.anatel.gov.br/dialogo/file/search?subtype=file\&page_owner=120>. Acesso em: 16 nov. 2016.

${ }^{28}$ Os documentos e discussões geradas a partir da "Consulta Pública n 8/2015 - Tomada de subsídios sobre a regulamentação da neutralidade de rede, prevista no Marco Civil da Internet” estão disponíveis em <http://www.anatel.gov.br/dialogo/file/search?subtype=file\&page_owner=120>. Acesso em: 16 nov. 2016. 
priorização do tráfego de determinado tipo de conteúdo, sem, contudo, ocorrer bloqueio aos demais conteúdos da aplicação ${ }^{29}$.

Conforme mapeamento realizado pelo Internet.lab ${ }^{30}$ a partir das contribuições enviadas à consulta pública do Ministério da Justiça existem, atualmente, três teses principais em relação às práticas de Zero Rating no debate público brasileiro. A primeira é defendida pela maioria das empresas de telefonia e de órgãos setoriais do serviço de telecomunicação, tais como a TIM, a SINDITELEBRASIL ${ }^{31}$ e a FEBRATEL $^{32}$. Para esse grupo, o Marco Civil não deveria considerar que os pacotes de Zero Rating sejam prejudiciais à concorrência, uma vez que a diferenciação de planos entre as operadoras pode ser positiva aos consumidores. Fundamenta esta posição o argumento de que os serviços de Tarifa Zero ampliam a conexão à internet, sobretudo de classes sociais menos favorecidas.

Uma segunda posição defendida pelo mercado de telefonia foi sustentada apenas pela Claro. Na visão dessa empresa, apesar de os planos Zero Rating configurarem uma exceção à neutralidade de rede, o Marco Civil da Internet não deveria vedá-los, permitindo assim a livre concorrência na internet, princípio igualmente previsto na norma.

A terceira tese a respeito dos planos Zero Rating foi defendida por membros da sociedade civil e organizações não governamentais, tais como o Intervozes, o Artigo 19 e o Instituto Brasileiro de Defesa do Consumidor (IDEC). De acordo com o quadro argumentativo desse grupo, os planos de Zero Rating não devem ser permitidos, pois os diferentes tipos de conexão gratuita oferecidos pelas prestadoras de serviço de

\footnotetext{
${ }^{29}$ Marcelo Castro, coordenador da MUV, empresa especializada em publicidade voltada para operadoras de telefonia móvel e fabricantes de dispositivos, aponta uma quinta classificação para modalidade de Zero Rating, o Data Rewards. Trata-se, segundo Castelo, de um sistema de bonificação em que o usuário é premiado com um pacote de dados gratuito após assistir vídeos publicitários de marcas anunciantes (CASTELO, 2016).

${ }^{30} \mathrm{O}$ estudo do Internet.lab, entidade sem fins lucrativos que reúne estudantes e pesquisadores na área de direito, tecnologia e internet, está disponível em <http://www.internetlab.org.br/pt/noticias/o-que-estaem-jogo-na-regulamentacao-do-marco-civil-da-internet/>. Acesso em: 16 nov. 2016.

${ }^{31}$ O SINDITELEBRASIL (Sindicato Nacional das Empresas de Telefonia e de Serviços Móvel Celular e Pessoal) atua desde setembro de 2003 na coordenação, defesa e representação legal das empresas da categoria. Entre as empresas representadas pelo sindicato, estão as quatro operadoras de telefonia móvel envolvidas na campanha "Acesso Gratuito ao Bradesco Celular", Claro, Oi, Tim e Vivo. Mais informações a respeito da atuação do SINDITELEBRASIL estão disponíveis em <http://www.sinditelebrasil.org.br/quem-somos/nossa-historia>. Acesso em: 16 nov. 2016.

${ }^{32}$ Sigla para Federação Brasileira de Telecomunicações.
} 
telefonia criam uma barreira de entrada aos novos desenvolvedores de aplicações. Além disso, na visão deles, os pacotes de Zero Rating contribuem para vigilância e censura da navegação dos internautas, uma vez que é sabido que a Agência Nacional de Segurança dos Estados Unidos (NSA) tem acesso a dados de empresas como o Facebook, uma das principais redes sociais oferecidas em planos de conexão gratuita.

Ao fim e ao cabo, após dois anos da sanção da Lei, o decreto regulamentador do Marco Civil da Internet, $\mathrm{n}^{\circ}$ 8.771, de 11 de maio de 2016, foi assinado pela presidente Dilma Rousseff ${ }^{33}$. O texto reservou oito artigos para tratar do tema da neutralidade de rede. Os artigos terceiro e quarto do decreto retomam a regra contida na referida lei que determina a exigência de tratamento isonômico dos pacotes de dados que trafegam na internet e conferem caráter excepcional à discriminação e degradação de tráfego, que só podem decorrer de requisitos técnicos indispensáveis à prestação adequada de serviços e aplicações ou da priorização dos serviços de emergência.

Tais exceções ao princípio de neutralidade são regulamentadas nos artigos $5^{\circ} \mathrm{e}$ $8^{\circ}$ do decreto:

Art. 5응 Os requisitos técnicos indispensáveis à prestação adequada de serviços e aplicações devem ser observados pelo responsável de atividades de transmissão, de comutação ou de roteamento, no âmbito de sua respectiva rede, e têm como objetivo manter sua estabilidade, segurança, integridade e funcionalidade.

$\S 1^{\circ}$ Os requisitos técnicos indispensáveis apontados no caput são aqueles decorrentes de:

I - tratamento de questões de segurança de redes, tais como restrição ao envio de mensagens em massa (spam) e controle de ataques de negação de serviço; e

II - tratamento de situações excepcionais de congestionamento de redes, tais como rotas alternativas em casos de interrupções da rota principal e em situações de emergência.

$\S 2$ 을 Agência Nacional de Telecomunicações - Anatel atuará na fiscalização e na apuração de infrações quanto aos requisitos técnicos elencados neste artigo, consideradas as diretrizes estabelecidas pelo Comitê Gestor da Internet - CGI.br.

[...] Art. 8o A degradação ou a discriminação decorrente da priorização de serviços de emergência somente poderá decorrer de: I - comunicações destinadas aos prestadores dos serviços de emergência, ou comunicação entre eles, conforme previsto na

\footnotetext{
${ }^{33} \mathrm{O}$ decreto regulamentador do Marco Civil da Internet foi um dos últimos atos da ex-presidente Dilma Rousseff. No dia 12 de maio de 2016, os senadores aprovaram a abertura do processo de impeachment da mandatária. Com a decisão, Dilma foi afastada do cargo até o julgamento final no Senado, que ocorreu em 31 de agosto do mesmo ano (PROCESSO..., 2016; SENADO..., 2016).
} 
regulamentação da Agência Nacional de Telecomunicações - Anatel; ou

II - comunicações necessárias para informar a população em situações de risco de desastre, de emergência ou de estado de calamidade pública.

Parágrafo único. A transmissão de dados nos casos elencados neste artigo será gratuita.

(BRASIL, 2016)

Os artigos $6^{\circ}$ e $7^{\circ}$ do decreto $\mathrm{n}^{\circ} 8.771$ tratam do gerenciamento de redes, que passam a ser permitidas para a "adequada prestação de serviços e aplicações na internet". A administração da rede, conforme regulamenta o decreto, deve ter o objetivo de preservar sua estabilidade, segurança e funcionalidade e deve utilizar medidas técnicas compatíveis com os padrões internacionais, observar parâmetros regulatórios expedidos pela Anatel e considerar diretrizes estabelecidas pelo CGI.br. O artigo $7^{\circ}$ trata das medidas de transparência que devem tomar nos casos em que houver o gerenciamento de redes.

O penúltimo artigo inserido no capítulo de neutralidade de rede do decreto, o artigo $9^{\circ}$, proíbe os responsáveis pela transmissão, comutação ou pelo roteamento de apresentar condutas unilaterais ou fechar acordos com provedores de aplicação. Como se nota a partir de uma possível interpretação do trecho destacado a seguir, a campanha de internet gratuita do Bradesco pode ser colocada na ilegalidade ${ }^{34}$ :

Art. 9o Ficam vedadas condutas unilaterais ou acordos entre o responsável pela transmissão, pela comutação ou pelo roteamento e os provedores de aplicação que:

I - comprometam o caráter público e irrestrito do acesso à internet e os fundamentos, os princípios e os objetivos do uso da internet no País;

II - priorizem pacotes de dados em razão de arranjos comerciais; ou III - privilegiem aplicações ofertadas pelo próprio responsável pela transmissão, pela comutação ou pelo roteamento ou por empresas integrantes de seu grupo econômico.

(BRASIL, 2016)

\footnotetext{
${ }^{34} \mathrm{Na}$ avaliação de Demi Getschko, diretor do Núcleo de Informação e Coordenação do Ponto BR (NIC.br) seria possível às operadoras de telecomunicação privilegiarem, por meio de campanhas publicitárias, o acesso a um serviço ou aplicativo específico em detrimento de outros. Isso porque, na avaliação de Getschko, tal prática não caracteriza uma oferta de acesso à internet, para qual não pode existir diferenciações, mas uma oferta de acesso a um aplicativo apenas (FARIELLO, 2016).
} 
Por fim, o artigo $10^{\circ}$ do decreto regulamentador do Marco Civil da Internet dispõe que ofertas comerciais e modelos de cobrança de acesso à internet devem "preservar uma internet única, de natureza aberta, plural e diversa, compreendida como um meio para a promoção do desenvolvimento humano, econômico, social e cultural (...)" (BRASIL, 2016).

Para o Intervozes, com tal texto, o decreto regulamentador superou os debates promovidos nas consultas públicas que antecederam sua publicação, avançando em questões defendidas pela sociedade civil organizada. Na visão do coletivo, os artigos que tratam da neutralidade de rede, ao vedar as práticas de Zero Rating e a priorização de pacotes de dados em função de acordos comerciais, são "centrais" para garantir o futuro da internet. Nos termos usados por uma integrante do Conselho Diretor do Intervozes, “a regulamentação do Marco Civil avançou para impedir que os interesses das teles transformem a rede em uma TV a cabo, em que é preciso assinar cada canal de interesse, ou pacotes pré-estabelecidos, e onde quem paga mais tem acesso a uma maior gama de conteúdo" (PITA, 2016).

Em lado oposto se posicionou o diretor de estratégia regulatória da América Móvil Brasil, Gilberto Sotto Mayor. Para o executivo, tanto o debate do Marco Civil da Internet como seu decreto regulamentador não foram devidamente analisados no Congresso Nacional, ainda que tais debates tenham tido um curso de cerca de quatro e dois anos, respectivamente. Como representante de uma grande corporação, a crítica de Mayor se dirige, como era de se esperar, à regulação num sentido geral. Em evento realizado em setembro deste ano declarou: “Temos que regular pouquíssimo, ou temos de desregular, porque já existem órgãos com competência, como Cade e Procon" (DO AMARAL, 2016a).

Ainda que não coadune inteiramente com essa tese, representando a Intel, Emílio Loures, no mesmo evento em que esteve Mayor, criticou os termos em que a neutralidade de rede vem sendo tratada no Brasil: "a grande proposta da neutralidade é o tratamento isonômico entre atores, é a concorrência, para garantir que a oferta de serviço, intermediada por um provedor de rede, não seja prejudicada" (DO AMARAL, 2016a).

Como noticiou o jornal O Globo, embora o Sinditelebrasil não tivesse se posicionado a respeito do assunto na primeira quinzena de maio de 2016, poucos dias 
após a publicação do decreto uma fonte ligada às operadoras de telecomunicação já havia avaliado que o decreto do Marco Civil "afetaria o modelo de negócio" dessas empresas (FARIELO, 2016).

Esse conjunto de interpretações e impressões a respeito do decreto regulamentador apresentados até aqui pode se tornar, num futuro próximo, um exercício inócuo. Conforme declarou Gilberto Kassab, chefe do Ministério da Ciência, Tecnologia, Comunicações e Inovações, já existia, no segundo semestre de 2016, uma demanda das empresas de telecomunicação para que a regulamentação do Marco Civil da Internet seja revista. Até dezembro do mesmo ano, a reivindicação das empresas não havia sido atendida pelo governo, mas, segundo declarou Kassab à imprensa, a questão passou a ser analisada pelo Ministério pelo menos desde outubro (POSSEBON, 2016). Ainda que a declaração do ministro esteja prenhe de intenções políticas, não seria um ponto fora da curva se, de fato, esse cenário se confirmasse nos próximos meses. 


\section{O DESENVOL VIMENTO HISTÓRICO DA INTERNET NO BRASIL E NO MUNDO}

Neste capítulo, são resgatados alguns dos principais eventos que marcaram o desenvolvimento da internet, da criação de seu arquétipo no contexto bélico-militar, a ARPANET, em 1969, até seu curso recente, na segunda década dos anos 2000.

O texto foi organizado em três sessões: a primeira parte traça um breve panorama da criação da rede até o começo dos anos 2000; num desdobramento deste tópico, a segunda parte se detém nos eventos que caracterizaram a gestação da rede no Brasil; por fim, a terceira sessão apresenta um painel dos últimos quinze anos da internet. Nessa última parte do capítulo, optou-se por apresentar o cenário global do desenvolvimento da internet e apontar, quando oportuno, alguns dos desdobramentos dos fatos narrados na trajetória brasileira da rede

Além de acervo de jornais e revistas, publicações especializadas e levantamentos de institutos de pesquisa, são tomados como referência, entre outras, as obras de Manuel Castells (1999, 2001, 2015), César Bolaño et al. (2007, 2012), Marcelo Carvalho (2006) e Vera Dantas (1988) que oferecem importantes contribuições a respeito do tema.

\subsection{Da Guerra Fria à virada do milênio}

Para grande parte dos estudiosos da internet (entre eles, CASTELLS, 1999, 2001; BOLAÑO et al., 2007, 2012; MCCHESNEY, 2013; SCHILLER, 2002), é no contexto da Guerra Fria que foi dada a largada para o surgimento da rede mundial de computadores.

O ponto de partida desta narrativa é a disputa travada entre os Estados Unidos e a União Soviética na segunda metade do século XX pelo domínio da tecnologia espacial. Nesse cenário, o lançamento do satélite soviético Sputinik I, em outubro de 1957, "assustou os centros de alta tecnologia estadunidense" (CASTELLS, 1999, p. 82). Em menos de um ano, foi fundada uma agência militar de pesquisas para retomar o protagonismo estadunidense na disputa espacial: a ARPA (Advanced Research Projects Agency). Inaugurada em fevereiro de 1958, a agência selava o compromisso 
do governo dos EUA de serem "iniciadores e não a vítima de surpresas tecnológicas estratégicas" 35 . Sua missão se resume, até os dias atuais, em "fazer investimentos cruciais em tecnologias inovadoras para a segurança nacional”.

Apesar de ter sido criada para organizar a reação estadunidense ao avanço soviético em pesquisas espaciais, a ARPA teve seu foco de atuação reposicionado pouco após seu primeiro ano de funcionamento. Devido à redistribuição do programa de satélites dos EUA à NASA (National Aeronautics and Space Administration) e demais projetos de mísseis balísticos a outras unidades militares, a agência passou a incentivar pesquisas básicas de longo prazo, com a participação da comunidade acadêmica (HAFNER, 1996).

Nos diversos estudos realizados pela ARPA com o objetivo de desenvolver tecnologias de difusão de informações de maneira descentralizada, ganhou destaque a participação de Joseph Licklider, contratado como diretor da área de Pesquisas de Comando e Controle da agência em 1962. Com a missão de "estudar como computadores interativos podiam ajudar a facilitar o fluxo de informações" (ISAACSON, 2014, p. 243), Licklider propôs, ainda em 1962, a implementação de uma rede que integrasse os diversos computadores das instituições e empresas financiadas pela ARPA, evitando assim que fossem desenvolvidos máquinas e softwares em linguagens diferentes. Tratava-se das ideias iniciais do que viria a ser a computação em rede (CARVALHO, 2006).

Ocorre que, na década de 1960, a criação de tais redes descentralizadas de difusão de informação era "de difícil implementação devido à ausência de tecnologia e à opção da indústria, que privilegiava o desenvolvimento de processadores centrais de maior capacidade" (LUCERO, 2011, p. 50). Coube, então, aos matemáticos e cientistas da computação, alinhados ao estamento militar da ARPA, os primeiros esforços para a construção da nova tecnologia. Desta forma, a partir de 1966, o centro de Pesquisas de Comando e Controle da ARPA, já sob responsabilidade de Robert Taylor, começou a arquitetar um projeto para interligar os computadores das instituições patrocinadas pela agência estadunidense, a ARPANET (CARVALHO, 2006). 35 As informações a respeito da agência estadunidense estão disponíveis em
<http://www.darpa.mil/about-us/about-darpa>. Acesso em: 3 dez. 2016. 
Duas tecnologias foram fundamentais para o desenvolvimento dessa rede. A primeira delas é a comutação por pacotes, desenvolvida no início da década de 60 , de forma independente por dois pesquisadores: Paul Baran na Rand Coporation, sediada nos Estados Unidos, e Donald Davies, no British National Physical Laboratory, no Reino Unido (CASTELLS, 2001; LUCERO, 2011). O projeto desenvolvido por Baran fazia parte de uma proposta que a Rand Corporation apresentou ao Departamento de Defesa estadunidense para criar um sistema de comunicação militar descentralizado e invulnerável a eventuais ataques nucleares da União Soviética. Ao permitir que as mensagens trocadas entres dois terminais fossem divididas em pequenos blocos, endereçados e enviados separadamente e remontados em seu destino, a comutação por pacotes tornava as redes de comunicação independentes de centros de comando e controle. Ignorada pela Força Aérea dos Estados Unidos, a tecnologia desenvolvida por Baran foi incorporada pelos cientistas da ARPA ao projeto de desenvolvimento da sua rede de computadores (LUCERO, 2011).

Uma segunda inovação central para o lançamento da ARPANET foi criada por Lawrence Roberts, engenheiro eletrônico originário do Instituto de Tecnologia de Massachusetts (MIT, na sigla em inglês), contratado pela ARPA para trabalhar na equipe de Robert Taylor. Combinando as ideias de computação em rede de Licklider e a de comutação de pacotes de Baran, Roberts criou o Interface Message Processor (IMP), equipamento que possibilitou a conexão remota entre computadores (CARVALHO, 2006; LUCERO, 2011). A máquina foi instalada na Universidade da Califórnia em Los Angeles (UCLA) em agosto de 1969. No mês seguinte, entrou em funcionamento a ARPANET conectando quatro grandes nós: além da UCLA, o Instituto de Pesquisa de Stanford (SRI, na sigla em inglês), a Universidade da Califórnia em Santa Bárbara (UCSB) e a Universidade de Utah (CASTELLS, 1999, p. 83). Estava fundada, assim, a base material e tecnológica a partir da qual a internet se desenvolveu nos anos seguintes.

Se estão claros alguns dos eventos que permitiram a interconexão dos computadores no final da década de sessenta, não há consenso entre os estudiosos da internet e das tecnologias da informação e da comunicação a respeito das motivações que levaram os cientistas e profissionais da ARPA a desenvolverem tal tecnologia. 
De acordo com a interpretação de Elton e Carey (2013), interessava à agência estadunidense, sobretudo, o compartilhamento de tempo e, por consequência, a economia de recursos. Como explicam os autores,

\begin{abstract}
Naqueles dias, um computador era um equipamento grande e caro, que podia ser acessado a partir de terminais, localizados no mesmo edifício, que eram conectados a ele ou, geralmente, usando pilhas de cartões ou fitas perfuradas para receber informações. Dado o alto custo e a escassez relativa desses computadores, benefícios significativos foram esperados dos sistemas de computação descentralizada, que permitiu aos usuários acessar um computador (o "computador central") disposto em um local a partir de um segundo computador ou terminal localizado em outro lugar e, por exemplo, usar um programa instalado no computador central para fazer um cálculo (ELTON; CAREY, 2013, p. 28, tradução nossa).
\end{abstract}

Essa também é a visão de Castells $(1999,2001)$ que argumenta ainda que eram "secundárias" as aplicações militares da ARPANET. Para o autor, o principal interesse da ARPA era "financiar a ciência da computação nos Estados Unidos e deixar que os cientistas fizessem seu trabalho, esperando que algo interessante surgisse disso" (CASTELLS, 2001, p. 20). Na linha argumentativa do autor, "a criação e o desenvolvimento da internet nas três últimas décadas do século $\mathrm{XX}$ foram consequência de uma fusão singular de estratégia militar, grande cooperação científica, iniciativa tecnológica e inovação contracultural" (CASTELLS, 1999, p. 82).

Bolaño et al. (2007) discordam da avaliação, afirmando que havia finalidades pragmáticas e de natureza ideológica já na concepção da ARPANET, o que justificaria os recursos despendidos no projeto. Tratava-se, segundo essa perspectiva, de um instrumento tecnológico a serviço da defesa de um determinado sistema político e econômico. Nas palavras dos autores,

A matriz da internet, a ARPANET foi inicialmente criada e mantida como instrumento tecnológico a serviço de uma estrutura política e econômica definida e se coordenou e dirigiu os esforços científicos, humanos, econômicos e tecnológicos das duas décadas anteriores no sentido da constituição da rede como defende Castells, é porque tinha a visão pragmática de utilizar esses esforços a favor de quem lhe financiava as despesas (BOLAÑO et al., 2007, p. 167). 
Aproxima-se dessa abordagem a análise de Lopes em "Informação, Conhecimento e Valor" (2008a). Segundo o autor, a partir da Primeira Guerra Mundial, “os sistemas de comunicação passaram a subordinar-se aos órgãos de defesa que, no caso dos Estados Unidos, começam a desempenhar um importante papel na condução das políticas de pesquisa e desenvolvimento" (p. 41). Após a Segunda Guerra Mundial tal processo teria se intensificado, conforme demonstra o autor, com a criação de toda uma estrutura institucional, um "complexo militar-industrial-acadêmico", que pretendia garantir aos Estados Unidos a superioridade tecnológica. Isso atendia a interesses militares e também econômicos, uma vez que, à época, a produção se tornava cada vez mais diversificada e internacionalizada, algo que exigia controle, estocagem e transmissão de quantidades cada vez maiores de informação. Nesse sentido, a configuração de uma "rede das redes", a ARPANET, em 1969, não se deu, na análise de Lopes, ao largo de objetivos hegemônicos do sistema em curso nos Estados Unidos

De fato, os recursos dispendidos pelo governo estadunidense em pesquisas militares no início da Guerra Fria superaram em cerca de 30 vezes o que foi gasto no período anterior à Segunda Guerra e somaram $90 \%$ da verba federal em pesquisa e desenvolvimento (EDWARDS, 1996). Em 1965, poucos anos após a Crise dos Mísseis, episódio que quase culminou em uma guerra nuclear entre Estados Unidos e Rússia, $80 \%$ dos fundos de pesquisa da indústria aeroespacial e $60 \%$ da eletrônica provinha do orçamento federal estadunidense (MATTELART, 2002).

A ARPANET se expandiu rapidamente nos anos seguintes à sua criação. Em um primeiro momento, houve um crescimento no número de localidades conectadas à rede da ARPA: em 1971, eram 15 e, no ano seguinte, 40 nós conectados (CASTELLS, 2001; BOLAÑO; CASTAÑEDA, 2004). Até o começo dos anos 1980, a estrutura tecnológica era utilizada, somente para a troca de informações a respeito de pesquisas militares. Nos anos seguintes, cresceu a demanda pela criação de novas redes de comunicação e, em 1980, a agência governamental estadunidense National Science Foundation (NSF) criou a CSNET (Computer Science Research Network), voltada para pesquisas da Ciência da Computação, e a BITNET (Because It's Time Network), para uso acadêmico não científico (CASTELLS, 1999). Em 1983, a ARPANET foi aberta a outros grupos da comunidade acadêmica e foi criada uma segunda rede somente para 
fins militares, a MILNET. Na década de noventa, observou-se o crescimento mundial da rede de computadores, para além das fronteiras acadêmicas.

Para compreender essa evolução da rede mundial de computadores, Bolaño et al. (2007) propõem uma divisão em três fases de desenvolvimento. Segundo os autores, os dez primeiros anos da ARPANET podem ser caracterizados como uma "fase experimental”, marcada por algumas características fundamentais: “a) a sua expansão lenta e gradual, eminentemente ligada a instituições de pesquisa [...]; e b) um modelo de financiamento sustentado com recursos públicos" (BOLAÑO et al., 2007, p. 170171). Nesse período de tempo, explicam os autores, foram inventados equipamentos, linguagens e tecnologias dedicados à interconexão entre computadores como, por exemplo, os microcomputadores (tais como Altair, Apple I, Apple II), os sistemas operacionais para computador (UNIX e DOS), os modems e a fibra ótica. Esse primeiro estágio de desenvolvimento da rede seria, desta forma, especialmente importante, "porque define a configuração que a ARPANET vai tomar no futuro, em termos de topologia de rede e de utilização de tecnologias criadas ou adaptadas para o seu funcionamento" (BOLAÑO et al., 2007, p. 171-174).

Uma das invenções mais importantes desse período foi o correio eletrônico. Em março de 1972, Ray Tomlinson, engenheiro eletrônico da empresa de tecnologia BBN Corporation, desenvolveu um software de envio e leitura de mensagens para a ARPANET. Em poucos meses, as utilidades da nova aplicação foram aprimoradas por Roberts, que permitiu aos usuários do programa, entre outras funções, encaminhar, responder e arquivar os correios recebidos. "A partir daí o e-mail decolou como a maior aplicação da rede por mais de uma década" (LEINER et al., entre 2003 e 2016).

Também foi nesse período que surgiu o protocolo TCP/IP. Como explica Castells (1999), ainda que fosse crescente nesses primeiros anos a capacidade de transmissão em volume de dados entre os terminais, não havia uma tecnologia que capacitasse os diferentes modelos de computadores a "conversar uns com os outros". "O primeiro passo nessa direção foi a criação de um protocolo de comunicação que todos os tipos de rede pudessem usar" (CASTELLS, 1999, p. 84). A concepção de tal tecnologia partiu dos estudos de dois cientistas da computação da ARPA, Vinton Cerf e Robert Kahn, em meados de 1973. Após uma série de melhorias e contribuições de outros pesquisadores, o protocolo TCP/IP tornou-se o padrão de comunicação entre os 
computadores dos Estados Unidos nos anos 1980 e, posteriormente, de outros países do mundo.

A segunda fase do desenvolvimento da rede de computadores foi inaugurada na década de oitenta, período em que as principais inovações tecnológicas buscavam abrir a rede de computadores a um número maior de pessoas e países (BOLAÑO et al., 2007, p. 175). Foi criado o primeiro serviço de informações online, o CompuServe em 1979, e o Sistema de Nomes de Domínios (Domain Name System, o DNS) em 1984, que, ao estabelecer uma organização por nomes das páginas em rede, e não mais por números, facilitava a experiência de navegação dos internautas. Surgiram também outras redes de comunicação, conforme visto acima, a CSNET e a BITNET em 1980 e a MILNET em 1983 (CASTELLS, 1999).

A robusta expansão do número de servidores e usuários conectados é uma das características centrais da segunda fase da história da rede de computadores. De acordo com dados apresentados por Bolaño et al. (2007), em menos de dez anos, saltou de 213 (agosto de 1981) para 159 mil (outubro de 1989) o número de servidores conectados à ARPANET, como se observa a seguir:

Tabela 2 - Número de servidores interconectados no mundo de 1969 a 1989

\begin{tabular}{ll}
\hline DATA & HOSTS \\
\hline Dez. de 1969 & 4 \\
Dez. de 1979 & 188 \\
Ago. de 1981 & 213 \\
Mai. de 1982 & 235 \\
Ago. de 1983 & 562 \\
Out. de 1984 & 1.024 \\
Out. de $\mathbf{1 9 8 5}$ & 1.961 \\
Nov. de $\mathbf{1 9 8 6}$ & 5.089 \\
Dez. de $\mathbf{1 9 8 7}$ & 28.174 \\
Out. de $\mathbf{1 9 8 8}$ & 56.000 \\
Out. de $\mathbf{1 9 8 9}$ & 159.000 \\
\hline Fonte: Bolaño et al. (2007); adaptada pela autora
\end{tabular}

Com a expansão de servidores e usuários, começou a se formar "a primeira cadeia econômica de exploração da rede, caracterizada principalmente pela constituição de uma ampla teia de servidores de acesso, funcionando basicamente como provedores de BBS [Bulletin Board System]" (BOLAÑO et al., 2007, p. 177), os chamados "sistemas de quadro de avisos", fóruns eletrônicos, cooperativos ou 
comerciais, que agregavam usuários com os mais variados tipos de interesse e que não necessitavam estar conectados à rede central de computadores estadunidense para se interconectarem. Ocorre que, no final da década de 1980 e princípio da década de 1990 , os BBS “migraram” para a internet, buscando usar um único protocolo de comunicação entre os computadores em rede. Essa integração dos BBS à "rede das redes" garantiu, na visão de Castells, a expansão da própria internet, uma vez que milhões de usuários de computadores se comunicavam via BBS (CASTELLS, 1999, p. 87).

De acordo com a argumentação de Bolaño et al. (2007), na década de oitenta começou a ser formado "um público dedicado, que passa a fazer uso da rede por hobby, reunido em fóruns de discussão online ou em torno dos BBS, popularizando o uso do e-mail e desenvolvendo programas que maximizam a capacidade de comunicação da rede" (BOLAÑO et al., 2007, p. 179).

Cumpre observar que foi precisamente nesse contexto que foi dada a largada para a ampla onda de reformas no setor de telecomunicações. O marco inicial desse processo foi o desmembramento da AT\&T, em 1984, nos Estados Unidos. A partir disso, como aponta Schiller (2002), observou-se um movimento de privatização e liberalização do setor em escala global, sobretudo na década de 1990. Isso porque, conforme argumenta o autor, com a produção capitalista cada vez mais transnacionalizada, havia uma demanda crescente por regimes de telecomunicações internacionais mais permissivos, o que, até o ano de 1996, resultou, segundo dados apresentados em Schiller (2002), na privatização de quarenta e quatro operadoras públicas de telecomunicações.

Há que se observar também que, ainda na década de 1980, com a crescente popularidade das redes de computadores, surgiram tecnologias concorrentes, que buscavam oferecer a seus usuários serviços similares, como a consulta de informações e troca de mensagens eletrônicas. Era o caso do francês Minitel, terminal de computador ligado à rede telefônica que, entre outros serviços, permitia a seus usuários realizarem transações bancárias, checarem a previsão do tempo, comprarem tíquetes de viagem e acessarem diversos tipos de serviços pessoais, inclusive de acompanhantes. O serviço foi bastante popular entre os franceses e não custava nada a seus usuários - a 
conexão era subsidiada pela estatal France Telecom ${ }^{36}$ (SCHOFIELD, 2012). No Brasil, empresas do sistema Telebrás lançaram neste período o Teletex e o Videotexto, que fornecia serviços de informação em televisores comuns a partir de um adaptador conectado ao sistema telefônico (CARVALHO, 2006).

Apesar do intenso crescimento observado na década de 1980, é no período seguinte, nos anos 1990, que a rede mundial de computadores tem uma expansão propriamente mundial. De acordo com dados levantados por Bolaño et al. (2007), em janeiro de 1993, já havia mais de um milhão de servidores conectados à rede. Em seis anos, esse número saltou para 43 milhões. Como argumenta Castells (2015), tal difusão em larga escala foi resultado da combinação de uma série de fatores: mudanças regulatórias, avanços nas telecomunicações, difusão de computadores pessoais, desenvolvimento de softwares que facilitaram a navegação, além de uma demanda crescente por formação de redes de comunicação, seja para fins empresariais ou sociais (CASTELLS, 2015, p. 109).

Duas tecnologias desenvolvidas naquela década tiveram importância fundamental nesse processo: a "teia mundial", mais conhecida pelo termo em inglês "World Wibe Web" e o navegador Mosaic (CASTELLS, 1999). O WWW, criado em 1990 por um grupo de pesquisadores liderados por Tim Berners Lee no Centre Européen pour la Recherche Nucleaire (CERN), é o sistema hipermídia que organiza o conteúdo das páginas da internet a partir dos dados que eles contêm e não pela localização geográfica das informações. Tal invenção facilitou a experiência de navegação de internautas "não-iniciados", que "ainda tinham dificuldade para usar a internet" (CASTELLS, 1999, p. 87).

A outra inovação ligada à expansão mundial da rede, o Mosaic, foi desenvolvida no National Center for Supercomputer Applications (NSCA), vinculado à Universidade de Illinois, no ano de 1992. Em síntese, trata-se, de acordo com Castells (2001), de um navegador que deu a internet uma face gráfica, ao permitir que fosse exibido numa mesma tela textos e imagens. Por meio dele, era "possível captar e distribuir imagens pela internet, bem como várias técnicas de interface importadas do mundo multimídia" (CASTELLS, 2001, p. 18).

\footnotetext{
${ }^{36}$ O serviço, que chegou a ter 20 milhões de usuários diários em meados dos anos 1990, foi desligado no ano de 2012 (PERCURSOR..., 2012).
} 
Ainda na década de noventa, dois importantes eventos, de natureza política e econômica, reorganizariam a estrutura e funcionamento da rede. Em fevereiro de 1990, a ARPANET, já tecnologicamente obsoleta, foi desativada. Assim, a NSFNET, rede ligada a National Science Foundation, tornou-se a espinha dorsal da internet. Em cinco anos, em 1995, foi a vez da própria NSFNET encerrar suas atividades. Isso ocorreu sobretudo devido a pressões comerciais e o crescimento de redes privadas de empresas e também de outras de natureza cooperativa sem fins lucrativos (CASTELLS, 1999). Com a consolidação da lógica mercantil, foi dado o início para a terceira fase da história da rede de computadores.

Foi nesse período que a internet passou a ter, finalmente, a configuração que assume até os dias atuais ${ }^{37}$ (BOLAÑO et al., 2007). A partir da segunda metade da década de 1990 foram desenvolvidas diversas aplicações comerciais e tecnologias para facilitar a navegação dos novos usuários, tais como: inovações em linguagens de computação (como o HTML, Java e PHP); navegadores de internet (como o Nestcape e o Internet Explorer); e programas de bate-papo (ICQ e MSN Messenger). Além disso, foram desenvolvidas e aprimoradas diferentes aplicações da rede como, por exemplo, o comércio eletrônico e os negócios em rede (e-commerce e o e-business, respectivamente); os grupos de discussão e os correios eletrônicos; e as bibliotecas virtuais (BOLAÑO et al., 2007, p. 187-189).

A economia da internet passou a se assentar nos serviços de acesso à rede: de um lado, provedores buscavam ser remunerados para conectar os usuários à internet, oferecendo acesso discado à rede, serviços de e-mail e hospedagem de páginas e, do outro lado, grandes agentes do mercado buscavam construir redes físicas de fibras ótica para conectar-se aos backbones existentes ou para criar novas espinhas dorsais. Nessa terceira fase de desenvolvimento da internet, também ganha destaque, na análise de Bolaño et al. (2007), o surgimento do que chamam de "mercado mundial de informação

\footnotetext{
${ }^{37}$ É também em 1995 que a rede de computadores passa a ser chamada de "Internet". Nesse ano, o Federal Networking Council, grupo formado por agências e órgãos federais estadunidense, aprovou uma resolução em que define o termo "Internet" como "o sistema global de informação que: (i) é logicamente ligado entre si por um único espaço de endereço global baseado no Internet Protocol (IP) ou suas extensões posteriores; (ii) é capaz de suportar comunicações usando o Transmission Control Protocol/Internet Protocol (TCP/IP) ou suas extensões posteriores e/ou outro protocolo IP compatível; (iii) fornece, usa ou torna compatível, de maneira pública ou privada, serviços de alto nível localizados na camada de comunicação ou em infraestruturas relacionadas aqui descritos" (LEINER et al., entre 2003 e 2016, tradução nossa).
} 
e entretenimento". Como argumentam os autores, os mega-portais de acesso à rede e de serviço informativo lançados nesse período representavam uma "importante reviravolta na rede":

Enquanto até pouco tempo atrás ela [a rede] não passava de uma gigantesca nuvem de informações desordenadas, agora essa nuvem passa a se dissipar, e a informação ganha uma ordem aparente quando passa a ser tratada como mercadoria, uma ordem imposta pelo mundo dos negócios que transaciona essa mercadoria (BOLAÑO et al., 2007, p. 197).

Três importantes processos que tomaram forma a partir desse contexto interessam particularmente a este estudo. Isso porque, ainda que sejam movimentos complexos, multicausais, estão diretamente vinculados ao avanço vigoroso da lógica comercial na internet. Em primeiro lugar, observa-se na terceira fase de desenvolvimento histórico a constituição de algumas das grandes empresas que dominarão a rede nos anos seguintes. É o caso dos motores de busca, páginas de diretórios da web e serviços de e-mail, tais como MSN, Yahoo!, Hotmail e Google. Conforme será visto na terceira seção deste capítulo, tais atores, junto de outras grandes empresas surgidas ao longo dos anos 2000, desempenharam importante papel na economia política da internet na medida em que articulam alianças e aquisições que carregam em si uma tendência de concentração e incorporação de agentes menores, desenvolvedores de ferramentas e modelos de negócios particulares da internet (BOLAÑO et. al., 2012, p. 40).

Observa-se também neste corte temporal a integração entre empresas típicas da internet com importantes companhias midiáticas. Em janeiro de 2000, houve o anúncio da fusão da AOL com a Time Warner, que possuía uma gigantesca "máquina de conteúdo" nos Estados Unidos: a empresa era controladora dos estúdios cinematográficos Warner Bros, da revista Time e de outras publicações impressas, e sua rede de canais de TV a cabo era a segunda maior da $\mathrm{AT} \& \mathrm{~T}^{38}$, atingindo $20 \%$ dos

\footnotetext{
${ }^{38}$ A AT\&T, sigla para Amercian Telephone and Telegraph Company, é uma operadora de telefonia estadunidense, provedora de TV a cabo e internet móvel e fixa, avaliada em US\$ 230,6 bilhões (AT\&T..., 2016). A empresa foi fundada em 1877 por Alexander Graham Bell e dois financiadores com o nome de Bell Company. Em 1884, foi criada a AT\&T como subsidiária da Bell para serviços de longa distância. No começo do século XX, a Bell Company foi reestruturada e, em 1903, a AT\&T se tornou a holding de dezenas empresas
} 
lares nos Estados Unidos. A negociação entre as duas companhias envolveu o pagamento de US\$ 162 bilhões por parte da AOL, o que garantiu 55\% das ações do novo conglomerado midiático, cabendo aos acionistas da Time os $45 \%$ restantes (SUTEL, 2000).

Pouco após o anúncio da fusão AOL-Time Warner, foi formada outra grande potência global midiática, quando a companhia francesa Vivendi e sua subsidiária de TV e cinema Canal Plus compraram a empresa de mídia canadense Seagram por US\$ 34 bilhões em ações. A nova empresa, Vivendi Universal, somou mais de US\$ 100 bilhões em valor de mercado, com negócios nos setores de cinema, televisão, música, edição, telefonia, internet, telecomunicações, além das áreas de distribuição de água, bebida, energia elétrica, transporte e construção ${ }^{39}$.

Como apontam Bolaño et al. (2007), havia à época de tais fusões uma aposta bilionária de que, em pouco tempo, a audiência da Indústria Cultural migraria para a internet. Desta forma, ainda conforme os autores, no caso específico da união AOLTime, as duas empresas buscavam atingir o maior público possível a partir do compartilhamento de fatores que apresentavam separadamente: (i) o conteúdo, fabricado pela Time Warner na forma de programação, títulos, marcas; (ii) uma ampla base física de redes de cabos óticos para transmissão de conteúdo audiovisual, também de propriedade da Time; e, por fim, (iii) a visibilidade no ambiente online, proporcionada pela vasta lista de assinantes da AOL.

Por fim, destaca-se, neste cenário dos anos 1990-2000, o estouro da bolha especulativa da internet. Como é sabido, havia uma euforia crescente em torno das possibilidades de negócios trazidos pela internet o que resultou em maciços aportes financeiros nas companhias que operavam na rede, a tal ponto que a cotação dos papeis da Amazon.com chegou a valer mais do que da fabricante de aviões Boeing. Em março

do grupo. Essa estrutura durou até 1984, quando houve a reforma das telecomunicações nos Estados Unidos (WU, 2012).

${ }^{39}$ Como relatam notícias divulgadas à época, a Vivendi era líder mundial de distribuição de água, com operações em 90 países e 220 mil empregados. A companhia francesa também atuava nos setores de energia, transporte e construção e controlava a segunda maior operadora de telefonia da França, a editora Havas e o grupo de filmes Pathé. Já o Canal Plus registrava 14 milhões de assinantes, constituindo-se a maior rede de TV paga da Europa. Conforme apontou-se em reportagens publicadas no ano 2000, ao comprar a Seagram, empresa canadense do setor de bebidas e entretenimento, a Vivendi buscava entrar no mercado estadunidense e incrementar o conteúdo do recém-lançado portal Vizzavi, criado em parceria com o Canal Plus e com a empresa inglesa de telefonia Vodafone (VIVENDI CONFIRMA..., 2000; VIVENDI..., 2000). 
de 2000, deu-se início a um processo de desaceleração de tal euforia, quando o valor das empresas "pontocom" na Bolsa de Valores Nasdaq começou a despencar. Com isso, houve um considerável enxugamento do setor: até janeiro de 2001, foram fechadas 270 “empresas.com" e passava de 10.000 o número de demissões nessas firmas (BOLAÑO et al., 2007).

A análise desses três processos em conjunto oferece indícios bastante consistentes da tendência à concentração observada na internet nos últimos anos, como será visto a seguir. Por ora, cabe apontar que é justamente sob este pano de fundo em que se iguala, nos Estados Unidos, o número de usuários e não usuários da rede mundial de computadores, como é possível observar no gráfico 1 e tabela 3:

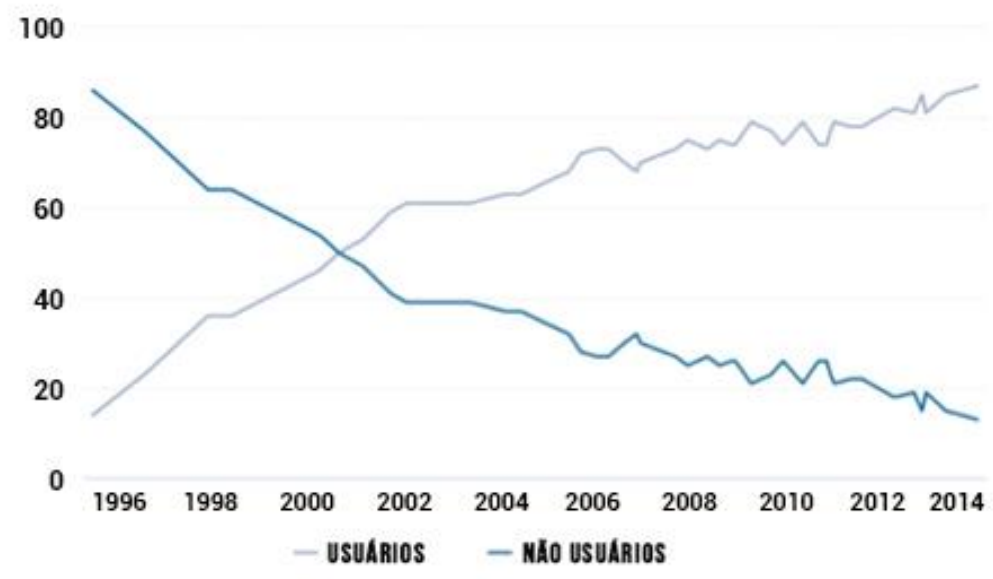

Gráfico 1 - Evolução do uso da internet nos Estados Unidos de 1995 a 2014 Fonte: Pew Research Center

Tabela 3 - Evolução do uso da internet nos Estados Unidos de 1995 a 2014

\begin{tabular}{lcc}
\hline Data da sondagem & \% Usuários da internet & \% Não usuários \\
\hline Jun. de $\mathbf{1 9 9 5}$ & 14 & 86 \\
Jul. de $\mathbf{1 9 9 6}$ & 23 & 77 \\
Nov. de $\mathbf{1 9 9 7}$ & 36 & 64 \\
Mai. de $\mathbf{1 9 9 8}$ & 36 & 64 \\
Ago. de $\mathbf{2 0 0 0}$ & 50 & 50 \\
Set. de $\mathbf{2 0 0 1}$ & 59 & 41 \\
Set. de 2002 & 61 & 39 \\
Mai. de $\mathbf{2 0 0 3}$ & 61 & 39 \\
Jun. de 2004 & 63 & 37 \\
Set. de 2005 & 72 & 28 \\
Dez. de 2006 & 70 & 30 \\
Dez. de 2007 & 75 & 25 \\
Dez. de 2008 & 74 & 26 \\
\hline
\end{tabular}




\begin{tabular}{lll}
\hline Dez. de 2009 & 74 & 26 \\
Dez. de 2010 & 77 & 23 \\
Ago. de 2011 & 78 & 22 \\
Dez. de 2012 & 81 & 19 \\
Set. de 2013 & 86 & 14 \\
Jan. de 2014 & 87 & 13 \\
\hline
\end{tabular}

Fonte: Pew Research Center

No cenário global, segundo estimativas do NUA Internet Surveys, o número de usuários conectados à internet saltou de 50 milhões em 1996 para 275,54 milhões no primeiro semestre do ano 2000, dos quais 136,06 milhões estavam no Canadá e Estados Unidos; 71,99 milhões na Europa; 54,90 na Ásia e Pacífico; 8,79 na América do Sul; 2,46 na África; e 1,29 no Oriente Médio. No ranking do número de internautas, os Estados Unidos lideravam o primeiro lugar com folga no começo dos anos 2000, como se observa no gráfico 2:

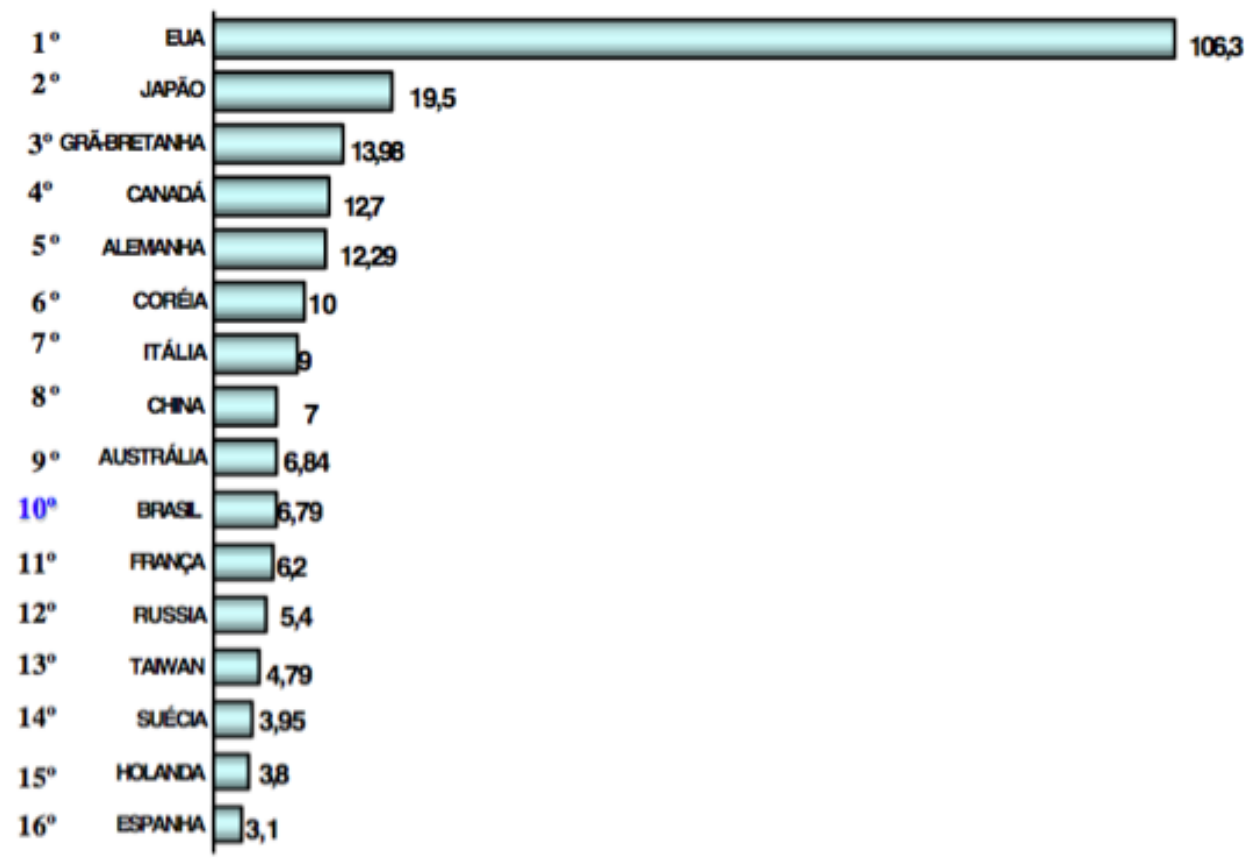

Gráfico 2 - Distribuição geográfica de internautas em 2000, em milhões de usuários Fonte: NUA Internet Surveys

Antes de seguir a análise do curso histórico da rede mundial de computadores, apresentando as inovações, fatos e acontecimentos que se deram nos últimos 15 anos, é importante resgatar alguns dos principais eventos ocorridos no cenário brasileiro até a penetração da internet comercial no país, sobretudo no campo da informática e das telecomunicações. O objetivo não é, mais uma vez, apontar todo 
o quadro legislativo e político em que se situa o desenvolvimento da rede no país, o que ultrapassaria os limites deste texto ${ }^{40}$, mas sim destacar importantes pontos de inflexão nesse trajeto, que são significativos do arranjo político e econômico de cada uma das décadas retratadas.

\subsection{A gestação da Internet no Brasil}

Conforme argumenta Benakouche (1997), a expansão da internet no Brasil na segunda metade da década de noventa só foi possível devido a diversas medidas do poder público na área de telecomunicações - intervenções essas que, segundo a autora, buscavam atender tanto a finalidades econômicas e nacionalistas como questões de ordem estratégico-militar.

Em uma breve revisão histórica, é possível encontrar já no Plano de Metas, do governo de Juscelino Kubitschek (1956-1961), a preocupação em se criar um robusto sistema de telecomunicações que permitisse a difusão de informações em todo território brasileiro, o que facilitaria o processo de "integração nacional”. Esse presidente também deu um grande impulso à utilização de computadores no país, ao autorizar que o governo estudasse a utilização dessas máquinas no âmbito do Plano de Metas (DANTAS, 1988) $^{41}$. Nos governos seguintes, de Jânio Quadros (1961) e João Goulart (1961-1964), houve a criação do Conselho Nacional de Telecomunicações (CONTEL) e a aprovação e regulamentação do Código Brasileiro de Telecomunicações (CBT) (CARVALHO, 2006). Tais eventos, que formaram o arcabouço básico da legislação brasileira do macrossetor de comunicações até a década de 1990 (BOLAÑO, 2003), coincidem, no corte temporal, com os antecedentes históricos da internet, vistos na seção anterior.

\footnotetext{
${ }^{40}$ Em Bolaño (2007) é possível encontrar uma detalhada análise do modelo de regulação do macrossetor das comunicações, de meados dos anos 1960 até o primeiro mandato do presidente Luiz Inácio Lula da Silva (2003-2010). Segundo constata o autor, há na política do audiovisual e nas políticas de comunicação em seu conjunto uma lógica que transita de uma perspectiva nacional desenvolvimentista para outra neoliberal a partir do governo do presidente Fernando Collor de Mello.

${ }^{41}$ Nesta dissertação, consultou-se a edição digital da referida obra, em que não consta a numeração das páginas. As citações de Dantas (1988) apresentadas ao longo deste e do próximo capítulo tomam como referência a numeração de página do documento digital, que não correspondem necessariamente à numeração do exemplar físico do livro.
} 
Mais tarde, com o golpe de Estado de 1964, não desapareceu do radar dos presidentes militares que comandaram o país nas duas décadas seguintes a preocupação de se criar uma infraestrutura de telecomunicações. E é justamente nesse período de interrupção democrática que se deram os primeiros eventos que compõem a moldura histórica do desenvolvimento da internet no país. Antes de seguir nesta análise, cumpre lembrar que, conforme visto anteriormente, o marco inicial da internet ocorreu em 1969, cinco anos, portanto, após a deflagração do golpe que levou os militares ao poder no Brasil. Como se sabe, o regime militar se estendeu até 1985 e, desta forma, acompanhou, na periodização de Bolaño et. al. (2007), todo o primeiro estágio e parte significativa da segunda fase do desenvolvimento da internet. Assim, não pode escapar à análise da trajetória brasileira o contexto de interdição da liberdade política e de privação de direitos civis em que o país se encontrava nos primeiros dezesseis anos da internet.

De partida, deve-se pontuar no quadro histórico brasileiro a criação de importantes órgãos que estruturaram o setor de telecomunicações no país, o que aconteceu, em sua maioria, logo nos primeiros anos da ditadura. Em 1965, foi constituída a Empresa Brasileira de Telecomunicações (Embratel), que buscava implantar a rede nacional de telecomunicações. Dois anos depois, em 1967, o CONTEL deu lugar ao Ministério das Comunicações, uma "superpasta" que, à época, centralizou as funções desempenhadas pelo primeiro órgão, pelo Departamento Nacional de Telecomunicações (Dentel), pela Embratel e incorporou a estrutura do então Departamento dos Correios e dos Telégrafos ${ }^{42}$. Tal mudança elevou o status político do setor e estabeleceu normas operacionais do Sistema Nacional de Telecomunicações (STN), segundo as quais a radiodifusão ficaria a cargo da iniciativa privada, enquanto o setor de telecomunicações ficaria sob o monopólio das empresas estatais (CARVALHO, 2006, p. 52). Por fim, já no ano de 1972, foi instituída a Telecomunicações Brasileiras ${ }^{43}$, uma sociedade de economia mista que tinha como atribuição planejar, implantar e operar o SNT.

\footnotetext{
${ }^{42}$ As informações a respeito das mudanças institucionais no âmbito do Ministério das Comunicações estavam disponíveis em <http://www.mcti.gov.br/o-ministerio/historico/23292-historico-do-ministeriodas-comunicacoes $>$. O endereço já não se encontra mais disponível.

${ }^{43} \mathrm{O}$ histórico da Telebras encontra-se disponível em 〈http://www.telebras.com.br/inst/?page_id=41 > Acesso em: 3 dez. 2016.
} 
O debate a respeito propriamente da informática, em nível governamental, começou a ganhar destaque na segunda metade da década de setenta, quando, em 1974, foi instituído o II Plano Nacional de Desenvolvimento (PND). Antes disso, porém, como descreve detalhadamente Dantas (1988), algumas iniciativas importantes marcaram o debut dos computadores na trajetória nacional. Em 1957, o governo do Estado de São Paulo adquiriu o primeiro computador do país, destinado a calcular o consumo de água na capital paulista. Em 1961, foi projetado e construído o primeiro computador do Brasil. Tratava-se do trabalho final de estudantes de engenharia do ITA que apelidaram a máquina de "Zezinho". Onze anos mais tarde, em 1972, foi a vez de estudantes da USP, do Laboratório de Sistemas Digitais, desenvolverem o "Patinho Feio", computador encomendado pela Marinha para equipar fragatas brasileiras.

Mas, como aponta Vera Dantas em "Guerrilha Tecnológica” (1988), nesses anos o parque de computadores instalados no país ainda era incipiente. De acordo com dados apresentados pela autora, em 1971, eram cerca de 600 máquinas no país. Em 1973, a Comissão de Coordenação das Atividades de Processamento Eletrônico (Capre) ${ }^{44}$ estimou que havia, ao todo, 700 computadores no país. Em 1974, o parque computacional do Brasil chegou a 2.772 computadores.

Justamente nesse ano, o presidente Ernesto Geisel editou o II Plano Nacional de Desenvolvimento. O governo militar pretendia, entre outras medidas, promover a indústria nacional de insumos e componentes eletrônicos e de equipamentos nacionais, em uma "segunda onda de substituição de importações no país" (KNIGHT, 2014). Como explica Dantas (1988), a indústria eletrônica assumia um papel mais destacado na estratégia de desenvolvimento que no I PND, editado no governo Médici:

[...] O II Plano Nacional de Desenvolvimento, traduzia o clima ambicioso e confiante da época: "O Brasil pode, validamente, aspirar ao desenvolvimento e à grandeza". E, em meio a grandiosas metas em todos os setores econômicos e sociais, abria um novo espaço para a indústria eletrônica. Reconhecida como "base da moderna indústria e administração", a eletrônica digital recebeu um tratamento mais

\footnotetext{
${ }^{44}$ Criada em 1972, a Capre tinha como objetivo inicial promover o uso mais eficiente dos computadores na administração pública e traçar uma política tecnológica para a área de informática. Como explica Dantas (1988), a instituição da Capre, em 1972, seguia uma tendência nos anos 1960 em que diversos países como Estados Unidos, Inglaterra, Alemanha e Japão, que adotaram um conjunto de medidas para expandir a demandas em seus mercados nacionais por produtos eletrônicos, desenvolver suas indústrias locais e apoiar pesquisa e formar recursos humanos na área informática.
} 
destacado que no I PND. Enquanto o Plano formulado no governo Médici para o período 1972 a 1974, apenas preconizava a inclusão de setores novos com alta densidade tecnológica - tais como química, metais não ferrosos, eletrônica, aeronáutica e construção naval - na política industrial do país, o II PND previu a implantação de uma indústria brasileira de minicomputadores sob controle de capital nacional, a fabricação de componentes eletrônicos sofisticados, como os circuitos integrados, e de centrais digitais de comutação, para a área de telecomunicações. Reconhecendo as carências tecnológicas do país, o Plano esperava que os investidores estrangeiros se interessassem pelos setores de alta tecnologia e que as empresas estrangeiras contribuíssem para o desenvolvimento da pesquisa, destinando recursos para os laboratórios e contratando a engenharia nacional (DANTAS, 1988, p. 50).

Ocorre que, diante do aumento do preço do petróleo registrado a partir de $1973^{45}$ e consequente encarecimento de importações, o cenário de crescimento e de desenvolvimento programado pelo II PND começou a vir por terra. Diversas multinacionais instaladas no país acumulavam déficits comerciais, que contribuíam para a situação econômica delicada que o Brasil vivia nesse período. Como aponta Dantas (1988), as 35 empresas estrangeiras do setor eletroeletrônico, entre elas as multinacionais de informática, acumulavam déficits de US\$ 619,3 milhões de dólares. Para reverter esse quadro, "no final de 1975, o governo não teve mais como adiar a adoção de duras medidas para controlar as importações" (DANTAS, 1988, p. 59).

Em alguns setores da economia, a importação passou a responder por um rígido controle de análise. Foi o caso da informática: uma resolução do Conselho Nacional de Comércio Exterior condicionou a concessão de guias de exportação a prévia autorização da Capre. Além disso, ficou determinado pelo Conselho de Desenvolvimento Econômico do governo, por meio de duas outras resoluções, que, nos anos de 1977 e 1978, o limite global para importações de computadores e periféricos seria de US\$ 100 e 130 milhões, respectivamente (TIGRE, 1981). Como se verá a seguir, a regra de reserva de mercado foi oficializada com a Lei da Informática em 1984.

\footnotetext{
${ }^{45}$ Em 1973 ocorreu o primeiro choque do petróleo, quando nações da Organização dos Países Exportadores de Petróleo (OPEP) embargaram o fornecimento do produto a Estados Unidos, Japão e Europa Ocidental. Também houve neste período uma diminuição da produção do petróleo, o que fez seu preço aumentar, em três meses, o preço do barril de US\$ 2,90 para US\$ 11,65 (O PRIMEIRO..., 2000?; BATISTA, 2014).
} 
Apesar de ter um papel destacado na condução das primeiras políticas voltadas à informática no país, a Capre acabou extinta em 1979. Como descreve Dantas (1988), com a troca de presidentes, de Geisel para João Batista Figueiredo, houve uma reestruturação de órgãos e agendas políticas, que pressionavam por alterações do órgão de informática. Além disso, alguns membros do novo governo nutriam duras críticas ao trabalho da Capre. O corpo técnico que viria a integrar o governo Figueiredo avaliava que não havia no país uma política para tecnologias da informação e que a Capre e outros órgão do setor não apresentavam hierarquia ou estrutura para formular a Política Nacional de Informática.

Foi criado então, em 1979, a Secretaria Especial de Informática (SEI ${ }^{46}$. Órgão vinculado ao Conselho Nacional de Segurança, a SEI tinha como finalidades centrais (i) assessorar na formulação da Política Nacional de Informática (PNI) ${ }^{47}$ e coordenar sua execução, (...) tendo em vista, especialmente, o desenvolvimento científico e tecnológico no setor e (ii) elaborar e propor o Plano Nacional de Informática, que seria submetido à aprovação do presidente da República. Somado a essas duas atribuições, o decreto que instituiu a SEI estabeleceu uma extensa lista de outras trinta e uma competências do órgão, tais como a administração de fundos e recursos destinados ao desenvolvimento da informática, a elaboração de normas e padrões técnicos, a análise da tarifação aduaneira de produtos e insumos importados pelo setor e o incentivo à formação de recursos humanos necessários ao setor da informática ${ }^{48}$. Como se observa, a SEI, que funcionou até o ano de 1990, conforme será visto a seguir, centralizou, por uma década, a formulação de políticas e as principais decisões relacionadas ao setor de Informática no país.

Alinhada ao nacionalismo militar vigente, essa Secretaria desempenhou importante papel no capítulo nacional do que Knight (2014) chama de "guerra de

\footnotetext{
${ }^{46} \mathrm{O}$ decreto $\mathrm{n}^{\circ}$ 84.067, de 2 de outubro de 1979, que criou a Secretaria Especial de Informática está disponível em 〈http://www.planalto.gov.br/ccivil 03/decreto/1970-1979/D84067.htm〉. Acesso em: 3 dez. 2016.

${ }^{47}$ Como será visto a seguir, a Política Nacional de Informática foi sancionada em 1984, por meio da lei de ${ }^{\circ} 7.232 / 1984$.

${ }^{48}$ A SEI foi organizada, inicialmente, em quatro subsecretarias: Assuntos Estratégico, Planejamento, Indústria e Serviços, que englobava temas relacionados a softwares, transmissão de dados e automação bancária (DANTAS, 1988).
} 
protocolos"49. Como aponta o autor, a SEI defendia que o Brasil adotasse o protocolo de comunicação desenvolvido pela Organização Internacional de Normalização (IOS, na sigla em inglês), o Open Systems Interconnection (OSI), em detrimento do protocolo TCP/IP, desenvolvido por Cerf e Kahn:

Este $[\mathrm{TCP} / \mathrm{IP}]$ era mais simples e mais barato, porque seu desenvolvimento foi subsidiado pelo governo dos EUA. Porém, sendo uma tecnologia inventada nos EUA, para os militares brasileiros, naquela época, a adoção do TCP/IP representaria uma reafirmação da hegemonia norte-americana (KNIGHT, 2014, p. 14).

Ainda nos anos 1970, além da criação da SEI, outros dois acontecimentos marcaram o contexto da gestação da internet no país. O primeiro deles ocorreu em 1975, quando Vint Cerf e Keith Uncapher, que participavam do Primeiro Seminário LatinoAmericano sobre Comunicação de Dados, em São Paulo, fizeram a primeira demonstração de acesso à ARPANET no Brasil (KNIGHT, 2014). Outro importante evento foi a edição do decreto 301, em abril daquele mesmo ano, que delegou à Embratel a tarefa de instalar e explorar uma rede nacional de transmissão de dados no país. Tal fato inseriu a questão da telemática na agenda política brasileira, algo que já estava em debate nos países centrais desde a década de 1960 (BENAKOUCHE, 1997).

Antes de avançar na análise de eventos que se sucederam nos anos 1980, cumpre resgatar aqui dois importantes debates internacionais em curso no final dos anos setenta e que ajudam a compor o quadro histórico brasileiro em tela. $\mathrm{O}$ primeiro deles, realizado sob a batuta da UNESCO, buscava apresentar uma série de propostas que estabelecessem uma Nova Ordem Mundial da Informação e da Comunicação (NOMIC). Como se sabe, tal discussão resultou na publicação do chamado "Relatório MacBride", conhecido no Brasil por "Um mundo e muitas vozes - Comunicação e informação na nossa época". O documento apresentava um diagnóstico sobre a problemática da Comunicação no começo dos anos oitenta e apontava, dentre outras questões, alternativas para solucionar o fluxo desigual de produtos midiáticos e a desigualdade tecnológica entre os países do globo (MELO, 2008).

\footnotetext{
${ }^{49}$ Como se verá a seguir, ao fim e ao cabo, o governo brasileiro acabou adotando o protocolo TCP/IP em meados da década de noventa.
} 
O fluxo de dados transfronteiriços também estava na pauta de debate da comunidade internacional. Nesse sentido, foi criado em 1978, com o apoio da UNESCO, o Intergovernamental Bureau for Informatics (IBI), que tinha como objetivo, além de debater tal questão, estimular a informática em países em desenvolvimento (CARVALHO, 2006; KNIGHT, 2014). Como aponta Knight, neste importante fórum internacional, a posição brasileira, articulada pelo Secretário Executivo da SEI, o tenente general Joubert de Oliveira Brizida, estava, mais uma vez, pautada pelo nacionalismo militar. Em uma conferência realizada na Itália em 1980, Brizida afirmou:

O país que não se preocupa com o controle das informações estratégicas que utiliza corre o risco de se tornar intoleravelmente dependente, através das telecomunicações, dos interesses de grupos políticos e econômicos fora de suas fronteiras (DANTAS, 1988, p. 143).

Tal nacionalismo também se fez presente na elaboração da Política Nacional de Informática (PNI), sancionada em 1984, que buscava estabelecer normas e diretrizes legais para o desenvolvimento da informática no país. Dentre outras medidas, a Lei ${ }^{\circ}$ 7.232/84 estabeleceu a reserva para as empresas de capital nacional do setor, ao instituir, por exemplo, um regime especial de incentivos tributários e financeiros a empresas brasileiras e o controle de importações de bens e serviços de informática por oito anos (art. $4^{\circ}$, alíneas VI e VII, respectivamente). Conforme aponta Dantas em "O crime de Prometeu" (1989) ${ }^{50}$, o Plano foi largamente criticado, por ser considerado um dos responsáveis pelo atraso tecnológico do Brasil, compondo o cenário de década perdida no país. Mas, segundo argumenta o autor, a Política Nacional de Informática criou "condição sine qua non de desenvolvimento, amadurecimento e competitividade tecnológica”, que permitiu o sucesso da difusão dos microcomputadores no Brasil (DANTAS, 1989, p. 74).

Avaliação semelhante faz Jorge Tapia (1995) a respeito da chamada Lei de Informática:

\footnotetext{
${ }^{50}$ Nesta dissertação, consultou-se a edição digital da referida obra, em que não consta a numeração das páginas. As citações de Marcos Dantas (1989) apresentadas ao longo deste capítulo e do próximo tomam como referência a numeração de página do documento digital, que não correspondem necessariamente à paginação do exemplar físico do livro.
} 
[A Lei 7.232/84] produziu resultados positivos dentro da lógica da substituição de importações, isto é, obteve uma internalização de produtos, criou um espaço importante para a acumulação do capital nacional, envolveu um esforço importante em atividades de pesquisa e desenvolvimento, gerou empregos qualificados e economizou divisas. Porém, não foi capaz de adquirir competitividade internacional (TAPIA, 1995, p. 241).

Já na fase final da ditadura, entre os anos de 1980 a 1985, tem início, enfim, o que Benakouche (1997) intitula de "pré-história" da internet no Brasil. Isso porque foi nesse período que o poder público estabeleceu diversas redes de transmissão de dados para atender instituições oficiais e privadas que necessitavam cada vez mais de redes telemáticas, seja para desempenhar suas atividades administrativas ou para estabelecer diálogo com entidades localizadas no exterior. Foram criadas, então, conforme aponta Benakouche, as estruturas tecnológicas da Transdata, Interdata, Findata, Airdata e Interbank ${ }^{51}$

Em outra frente, para difundir o uso de transmissão de dados entre os usuários domésticos brasileiros, o governo também implantou, em 1985, a Rede Nacional de Comunicação de Dados por Comutação de Pacotes (Renpac) e um serviço de oferta de informações telemáticas chamado Cirandão ${ }^{52}$, que oferecia, entre outros itens, lista de discussões, acesso restrito a bancos de dados e quadros de pequenos anúncios e avisos (TELECOMUNICAÇÕES BRASILEIRAS, 1987).

Apesar de o poder público ter se esforçado para difundir o uso da teleinformática entre os brasileiros, a rede Renpac e o Cirandão registraram, em 1987, apenas 110 assinantes e 2.256 usuários respectivamente. Em mais uma tentativa de reverter tal quadro e aumentar o interesse pela transmissão de dados no país, a Embratel buscou diversificar os conteúdos e serviços ofertados em seus sistemas, estabelecendo

\footnotetext{
${ }^{51}$ As siglas referem-se respectivamente a: Serviço Digital de Transmissão de Dados via terrestre; Serviço Internacional de Comunicação de Dados; Serviço Internacional de Acesso a Informações Financeiras; Serviço Internacional de Comunicação de Dados Aeroviários; e Serviço Internacional de Dados Bancários.

52 O Cirandão era, na verdade, uma extensão da rede Ciranda, criada em 1982 para uso exclusivo de funcionários da Embratel. Como explica Benakouche (1997), tal rede buscava capacitar profissionalmente os trabalhadores da estatal no uso de computadores e no domínio de técnicas digitais de transmissão de dados. O grupo de funcionários da Embratel utilizadores da rede Ciranda formou, segundo argumenta a autora, a primeira comunidade teleinformatizada do país.
} 
parcerias com associações profissionais, com a fundação Pró-memória (que relatava os trabalhos da Assembleia Nacional Constituinte de 1987) e até mesmo com a Bolsa de Valores do Rio de Janeiro (BENAKOUCHE, 1997).

Se as redes telemáticas não faziam sucesso entre os clientes da Embratel, na comunidade acadêmica brasileira o cenário da comunicação de dados era bastante diferente. Como aponta Carvalho (2006), em panorama bastante detalhado sobre o assunto, ao longo da década de oitenta observou-se "um processo marcado por múltiplas tentativas de conexão [de institutos de pesquisa do Brasil com seus pares no exterior] que, de forma desordenada, apontaram para várias direções” (p. 106). Tais embriões de redes independentes, nos termos de Bolaño et al. (2003, p. 56), que existiam no Brasil na década de oitenta enfrentavam, no entanto, obstáculos de ordem política, econômica e técnica. Divergências a respeito dos modelos de tarifação e cobrança, da possibilidade de compartilhamento de circuitos físicos e da utilização do protocolo TCP/IP, preterido pela SEI, como visto anteriormente, além da preocupação com o fluxo de dados transfronteiriços, dificultavam o diálogo dos pesquisadores com o poder público e a ampla penetração da comunicação de dados na comunidade acadêmica (CARVALHO, 2006).

Três instituições pioneiras na história da internet conseguiram, no entanto, driblar, em caráter excepcional, tais contratempos técnicos e políticos e conseguiram se conectar à BITNET nos Estados Unidos ainda no final da década de oitenta. Em 1988, o Laboratório Nacional de Computação Científica (LNCC) e a Fundação de Amparo à Pesquisa do Estado de São Paulo (FAPESP) estabeleceram conexões com duas instituições estadunidense. Nos meses seguintes, foi a vez da Universidade Federal do Rio de Janeiro (UFRJ) se conectar à BITNET (REDE NACIONAL DE ENSINO E PEQUISA, 2015).

A partir de 1989, o cenário das redes telemáticas acadêmicas começa a se organizar, quando, após diversas reuniões e tratativas envolvendo entidades do poder público (como a SEI, Embratel, CNPq e SERPRO) e entidades científicas e de pesquisa (CARVALHO, 2006), as diferentes iniciativas e experiências de redes acadêmicas distribuídas pelo Brasil foram agrupadas em um único projeto de alcance nacional. Em setembro daquele ano foi fundada, pelo Ministério da Ciência e Tecnologia, a Rede Nacional de Pesquisa (RNP), que tinha como objetivo construir a infraestrutura de 
internet de uso acadêmico do país e disseminar o uso de rede no Brasil. Em três anos, foi implantada a primeira rede acadêmica da RNP, alcançando 10 estados e o Distrito Federal $^{53}$, como ilustra a figura 2:

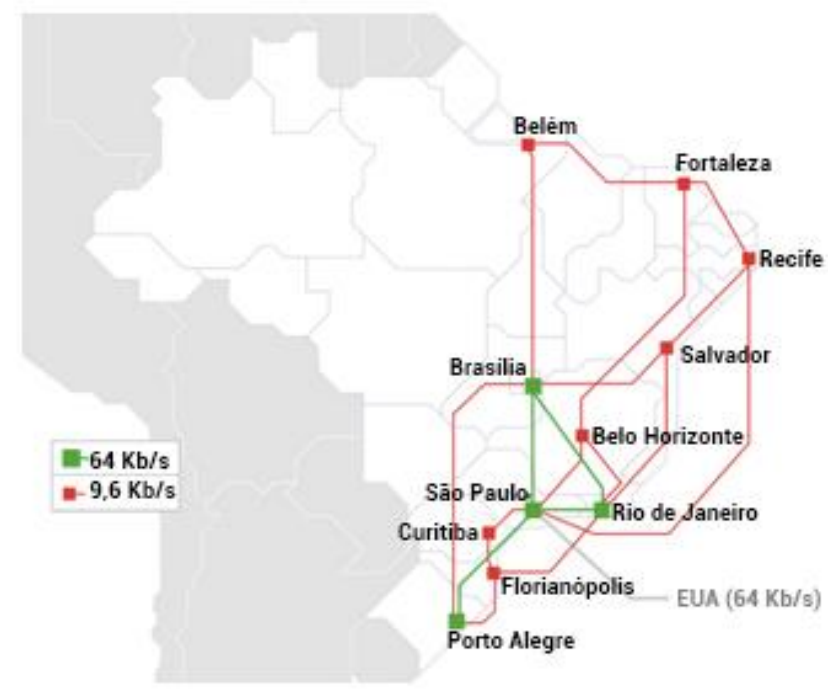

Figura 2 - Conexão da RNP em 1992

Fonte: RNP

Da pré-história da internet no Brasil à formação da RNP, cabe registrar ainda no quadro histórico brasileiro, a promulgação da Constituição Federal, em 1988. No domínio das telecomunicações, que interessa particularmente a este estudo, não obstante as investidas de modelos neoliberais, ficou garantido na Carta de 1988 que caberia à União explorar direta ou indiretamente os serviços de telecomunicações e legislar privativamente sobre esse tema e sobre a Informática, conforme disposto nos $\operatorname{artigos} 21^{\circ}$ e $22^{\circ}$, respectivamente (CARVALHO, 2006).

Encerrado, então, o complexo contexto político e social dos anos oitenta, é, finalmente, na década de noventa que a comunidade brasileira irá se conectar à internet. No curto mandato de Fernando Collor de Mello na presidência do Brasil (1990-1992), no plano normativo, foram tomadas, ao menos, duas medidas de considerável impacto

\footnotetext{
${ }^{53}$ A história da RNP encontra-se disponível em <https://www.rnp.br/institucional/nossa-historia>. Acesso em: 3 dez. 2016.
} 
no setor de Informática e da telemática. Em primeiro lugar, com a sanção da Lei $\mathrm{n}^{\mathrm{o}}$ 8.248/1991, que tratava da capacitação e competitividade do setor de informática e automação, a Política Nacional de Informática, sancionada sete anos antes, e a reserva do mercado de informática, instituída em 1975, começou a ser desmontada (CARVALHO, 2006). Como argumenta Bolaño (2003; 2007), tal legislação foi um dos primeiros passos rumo ao processo de liberalização, que tomou corpo nos anos seguintes. Em síntese, representou uma derrota incontestável para o viés nacionalista herdado de governos passados e abriu as portas para uma maior integração do capital nacional e estrangeiro nesse setor (2003, p. 59).

Ainda no governo de Collor, houve a dissolução da poderosa SEI, que deu lugar ao Departamento de Política de Informática e Automação (Depin) na Secretaria de Ciência e Tecnologia, que, por sua vez, substituía o Ministério da Ciência e Tecnologia (KNIGHT, 2014). Com essa nova composição, o Depin "continuou a controlar os fluxos de dados transfronteiriços em teoria, mas, na prática, com a globalização e o crescimento da internet, deixou de exercer as suas prerrogativas" (KNIGHT, 2014, p. 47 e 48). Como aponta Carvalho (2006), tal mudança resultou no fim da oposição que fazia o governo ao uso acadêmico do TCP/IP.

No plano político-econômico, em 1992, desempenhou importância fundamental para a história da internet no Brasil a Conferência das Nações Unidas sobre o Meio Ambiente e o Desenvolvimento, a Rio 92. Isso porque, paralelo ao encontro da ONU, ocorria o Fórum Global 92, evento que reuniu organizações não-governamentais, que demandou dos anfitriões brasileiros uma infraestrutura de comunicação que permitisse a conexão com redes do exterior. Para resolver o problema, foi contratada uma tecnologia baseada em BBS, a Alternex, do Instituto Brasileiro de Análises Sociais e Econômicas (Ibase), ONG sediada no Rio de Janeiro ${ }^{54}$. "Antes da abertura para a internet comercial no Brasil, foi a primeira vez em que pessoas físicas não vinculadas à universidade puderam ter uma experiência semelhante à transferência de arquivos e uso de correio eletrônico" (REDE NACIONAL DE ENSINO E PEQUISA, 2015).

\footnotetext{
${ }^{54} \mathrm{O}$ instituto foi fundado em 1981, após a anistia política de um dos seus fundadores, o ativista Herbert de Sousa, conhecido como Betinho. A página do Ibase na internet encontra-se disponível em <http://ibase.br/pt/>. Acesso em: $1^{\circ}$ fev. 2016.
} 
Já a partir de 1995, com o início da terceira fase de desenvolvimento da internet, marcada pela privatização de sua espinha dorsal e o avanço da lógica comercial na rede, ganham destaque no cenário político brasileiro três importantes medidas que organizam o setor no país. Em maio de 1995, foi criado, por meio da Portaria Interministerial $147^{55}$, dos Ministérios das Comunicações e da Ciência e Tecnologia, o Comitê Gestor da Internet (CGI.br), um importante órgão multissetorial responsável por acompanhar o desenvolvimento da rede de computadores no Brasil. O documento que criou o CGI.br destacava a necessidade de "coordenar e integrar todas as iniciativas de serviços internet no país" e designava ao Comitê, dentre outras atribuições, recomendar padrões, procedimentos técnicos e operacionais e código de ética de uso, para todos os serviços internet no Brasil; coordenar a atribuição de endereços IP (Internet Protocol) e o registro de nomes de domínios; e coletar, organizar e disseminar informações sobre o serviço internet no país.

Neste mesmo ano, o Ministério das Comunicações elaborou e publicou a Norma 4/1995, um dos principais marcos da história da rede no Brasil. Ao estabelecer que a internet era um Serviço de Valor Agregado, que "acrescenta a uma rede preexistentes (...) meios e recursos que criam novas utilidades específicas ou novas atividades produtivas", tal norma buscava extinguir as pretensões monopolísticas da Embratel na oferta de serviços de conexão ${ }^{56}$. Isso ocorreu porque, como explica Ivan Moura Campos ${ }^{57}$, "o ministro [das Comunicações] Sérgio Motta tinha firme convicção de que a internet e as telecomunicações só teriam competitividade e sucesso se fossem território próprio da iniciativa privada" (PRESCOTT, 2016, p. 7).

A norma reconheceu, então, o papel do provedor privado e determinou a função de "atacadista de serviços de internet" 58 à Embratel (PRESCOTT, 2016). Assim ficou

55 O texto da Portaria Interministerial de $\mathrm{n}^{\circ} 147$ encontra-se disponível em <http://www.cgi.br/portarias/numero/Portaria_147.pdf $>$. Acesso em: 3 dez. 2016.

${ }^{56}$ Como explica Carvalho (2006), a empresa havia iniciado no mês de dezembro de 1994, em caráter experimental, um serviço de acesso à internet via linha discada, algo que gerou descontentamento em vários setores da sociedade, que temiam uma possível precarização dos serviços de internet no país, e tampouco agradou ao governo.

${ }^{57}$ Em meados dos anos noventa, Campos foi secretário nacional de Política de Informática do Ministério da Ciência e Tecnologia. Na década seguinte, coordenou o CGI.br (BARROS, 2014).

${ }^{58}$ Tal definição foi dada por Tadao Takahashi, um dos fundadores do Comitê Gestor da Internet no Brasil. Engenheiro da computação, entre 1988 e 1996, Takahashi criou e foi coordenador-geral da RNP (REDE NACIONAL DE ENSINO E PESQUISA, 2015). 
disposta a relação entre os meios da Rede Pública de Telecomunicações e os Provedores de Serviço de Conexão à Internet:

5.1. O uso de meios da Rede Pública de Telecomunicações, para o provimento e utilização de Serviços de Conexão à Internet, far-se-á por intermédio dos Serviços de Telecomunicações prestados pelas Entidades Exploradoras de Serviços Públicos de Telecomunicações. 5.2. O Provedor de Serviço de Conexão à Internet pode, para constituir o seu serviço, utilizar a seu critério e escolha, quaisquer dos Serviços de Telecomunicações prestados pela EESPT.

5.3. Os meios da Rede Pública de Telecomunicações serão providos a todos os PSCIs que os solicitarem, sem exclusividade, em qualquer ponto do território nacional, observadas as condições técnicas e operacionais pertinentes e, também, poderão ser utilizados para:

a) conectar SCIs à internet, no exterior;

b) interconectar SCIs de diferentes provedores.

5.4. As Entidades Exploradoras de Serviços Públicos de Telecomunicações não discriminarão os diversos PSCIs quando do provimento de meios da Rede Pública de Telecomunicações para a prestação de Serviços de Conexão à Internet. Os prazos, padrões de qualidade e atendimento, e os valores praticados serão os regularmente fixados na prestação do Serviço de Telecomunicações utilizado.

5.5. É facultado ao Usuário de Serviço de Conexão à Internet, o acesso ao SCI por quaisquer meios da Rede Pública de Telecomunicações à sua disposição.

(BRASIL, 1995; grifo nosso).

Dois anos após a publicação da Norma 4/1995, foi sancionada a Lei Geral de Telecomunicações (Lei $\left.n^{\circ} 9.472 / 1997\right)^{59}$, que além de criar a agência reguladora do

\footnotetext{
${ }^{59}$ Em dezembro de 2016, a Comissão Especial do Desenvolvimento Nacional do Senado Federal aprovou, em caráter terminativo, um projeto de lei que altera pontos importantes da LGT, o PLC 79/2016. A proposta de "modernização" do marco regulatório das comunicações foi originalmente apresentada pelo deputado Daniel Vilela (PMDB-GO) em 2015 (Projeto de Lei 3.453/2015). O texto propõe, entre outras coisas, a adaptação da modalidade outorga do serviço de telecomunicações de concessão para autorização. De acordo com o projeto, o pedido de adaptação apresentado pelas concessionárias deverá ser analisado pela Anatel que, em sua decisão, verificará o cumprimento de alguns requisitos como a garantia da prestação de serviço em áreas sem concorrência. Outro ponto bastante controverso do PLC é a transferência da infraestrutura pública para o setor privado. É estabelecido no texto um mecanismo de incorporações dos bens reversíveis (aqueles afetados à prestação do serviço e que são revertidos ao poder público ao término da concessão) ao patrimônio das empresas em contrapartida a novos compromissos de investimentos. Em $1^{\circ}$ de fevereiro de 2017, o então presidente do Senado, Renan Calheiros (PMDB$\mathrm{AL}$ ), enviou o projeto de lei à sanção presidencial. No mesmo dia, após um grupo de senadores da oposição anunciar que apresentaria uma medida judicial contestando o trâmite da matéria no recesso parlamentar, a Mesa do Senado pediu a Casa Civil que o projeto fosse remetido novamente ao Congresso (BITTENCOURT; RESENDE, 2016; COMISSÃO..., 2016; TCU..., 2016). Os documentos e informações complementares relativas ao PLC 79/2016 estão disponíveis em: < http://www25.senado.leg.br/web/atividade/materias/-/materia/127688 >. Acesso em: 4 fev. 2017.
} 
setor, a Anatel (Agência Nacional de Telecomunicações), autorizou o governo a "reestruturar e desestatizar" as empresas federais de telecomunicações, controladas diretas ou indiretamente pela União, como a TELEBRAS, a EMBRATEL, TELEREJ e a TELESP ${ }^{60}$ (art. 187), iniciando o ciclo de privatizações realizados pelo Estado brasileiro nos anos seguintes.

Cabe destacar neste ponto a criação do paradoxo da radiodifusão, conforme avalia Murilo Ramos (1997). Segundo explanação do autor, o antigo CBT, que já completava mais de 30 anos, apresentava indistintamente a regulamentação de telecomunicação e radiodifusão. Com a LGT, há uma reestruturação do primeiro setor, sem alterar o sistema de rádio e televisão, dominado, no país, por interesses políticos fortemente representados no Congresso Nacional (RAMOS, 1997, 176-182).

Foi diante de tal quadro político e normativo da década de noventa, que a internet comercial começou a operar no Brasil. Com o fim do monopólio estatal da Embratel, fundamentado pela Norma 4/1995, diversas empresas, muitas delas, fornecedores de BBS no país, passaram a funcionar como provedores de acesso à internet (PRESCOTT, 2015). Conforme apontava o Guia do Empreendedor Internet/Brasil, publicado pela RNP em abril 1996, o negócio era "potencialmente muito atraente" (REDE NACIONAL DE ENSINO E PESQUISA, 1996, p. 32). Isso porque, de acordo com estimativas elaboradas pelo documento, um provedor de acesso à internet de porte médio, que oferecesse acesso discado a 320 usuários, dispenderia $\mathrm{R} \$$ 153,7 mil ${ }^{61}$ de capital inicial em seu negócio. Considerando uma receita estimada de $\mathrm{R} \$ 20$ mil e custos de manutenção médio na casa dos $\mathrm{R} \$ 8$ mil, o provedor teria um superávit de R\$10 mil por mês ${ }^{62}$.

Com tais perspectivas de lucro no mercado, em 1997, já havia mais de quinhentas empresas oferecendo acesso à internet no país. Dentro desse numeroso grupo, é possível identificar ao menos dois perfis distintos de provedores privados no

\footnotetext{
${ }^{60}$ Como avalia Dantas (2002), em estudo detalhado sobre o assunto, esse processo, além de não gerar uma expansão do investimento em telecomunicações pelos operadores privados, resultou em volumosos déficits na balança comercial do setor (p. 60-64).

${ }^{61}$ Corrigido pelo IPCA, o valor corresponderia a R $\$ 557$ mil em abril de 2016. O cálculo foi feito a partir da ferramenta "Calculadora do cidadão" disponível no site do Banco Central <https://www3.bcb.gov.br/CALCIDADAO/publico/corrigirPorIndice.do?method=corrigirPorIndice>. Acesso em: 4 out. 2016.

${ }^{62}$ Os valores citados corresponderiam, em abril de 2016, a R\$ 72,5 mil, R\$ 29 mil e R\$ 36,2 mil, respectivamente, corrigidos pelo IPCA.
} 
cenário brasileiro, como explicam Bolaño et al. (2007). Havia aqueles ligados a grandes grupos de comunicação, como UOL, associado à Folha de S. Paulo e à editora Abril, e o SOL do grupo Silvio Santos, que, além da possibilidade de realizar campanhas publicitárias em veículos de posição destacada no mercado impresso e televisivo, tinham considerável capital para investir em infraestrutura. Por outro lado, havia provedores menores que funcionavam como "incubadoras de internet": tratava-se de pequenas empresas que estabeleciam parcerias com grandes grupos econômicos e instituições financeiras, como, por exemplo, o provedor Mandic, do GP Investimento que, por sua vez, era gerido pelo Banco Garantia (BOLAÑO et al., 2007, p. 204).

Juntamente com o crescimento no número de provedores de acesso comercial à internet surgiram no país as primeiras entidades representativas dos interesses da classe, como a Associação Brasileira dos Provedores de Acesso, Serviços e Informações da Rede Internet (Abranet), fundada em 7 de novembro de 1996. Uma das dificuldades enfrentadas pelo setor à época era o fato de as operadoras de telecomunicações darem preferência no atendimento a grandes players (CARVALHO, 2006). Além disso, como indica Bolaño et. al. (2007), era difícil conquistar uma ampla base de assinantes, uma vez que havia baixo índice de computadores no país e altos custos de manutenção. Outra pauta de contestação da Abranet foi o processo de verticalização das operadoras de telecomunicações que, com o tempo, passaram a comprar provedores para fornecer, elas mesmas, o acesso à internet aos usuários (PRESCOTT, 2015).

Já no começo dos anos 2000, uma questão central enfrentada pela Abranet e pelos provedores privados foi o lançamento de dezenas de provedores gratuitos no país. Tal processo teve início ainda em dezembro de 1999, quando o banco Bradesco anunciou que forneceria conexão à internet a seus clientes. Nos meses seguintes, já havia no mercado brasileiro dezenas de outros provedores gratuitos, tais como o iG, NetGratuita, BrFree, Super11.net (BOLAÑO et al., 2007). Com a entrada desses agentes no mercado, os internautas não precisavam mais pagar às empresas de acesso à rede: bastava assinar os serviços de um provedor "gratuito" e, em troca do acesso, receber "uma montanha de publicidade", além de serem empurrados para páginas de lojas virtuais (PANTOJA; FERREIRA, 2000), como será visto no capítulo a seguir.

Como explicam Bolaño et al. (2007), o surgimento desses provedores era reflexo de um fenômeno que já vinha se consolidando no cenário internacional há 
alguns anos. Em setembro de 1998, foi lançado na Inglaterra, o FreeServe, que, em apenas cinco meses de funcionamento, já possuía um milhão de clientes e era portal o mais visitado da Europa. Em abril de 2000, quase dois milhões de usuários estavam cadastrados nesse provedor inglês (APESAR..., 2003). Nos Estados Unidos, a situação não era diferente: no começo dos anos 2000, mais de trezentos provedores gratuitos estavam em atuação no mercado, entre eles o 1Nation Online, 1stUp, Bluelight, FreeInternet, FreeWWWeb, NetZero, Juno Online e Start Free (INTERNET..., 2003).

Ainda que o número de provedores de acesso grátis no Brasil não tenha alcançado a casa das centenas, houve uma considerável desestabilização do mercado brasileiro de exploração econômica de acesso à rede que, até então, se baseava principalmente em pequenos provedores de acesso locais (BOLAÑO et al., 2007). Ainda que fosse crescente o número de usuários de provedores ${ }^{63}$, como se observa no a seguir, após um ápice de 600 empresas em 1997, havia, no ano 2000, cerca de 150 provedores funcionando no país.

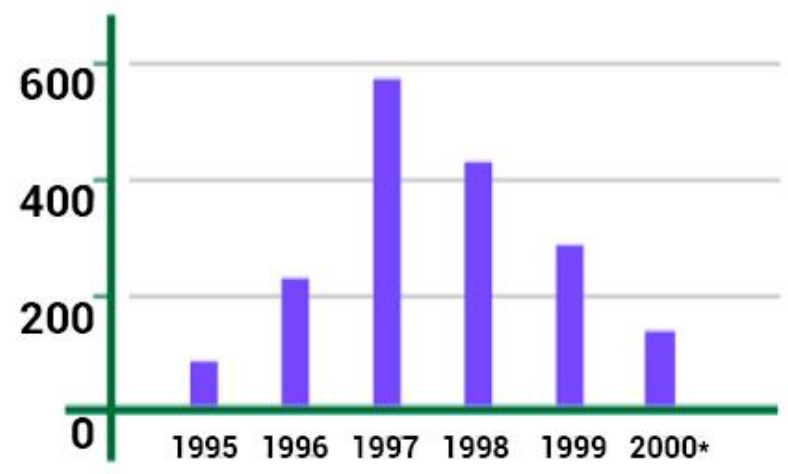

Gráfico 3 - Evolução do número de provedores no país Fonte: Abranet

Também contribuiu para esse quadro, como reconheceu o próprio Ministério da Ciência e Tecnologia à época, o estabelecimento de fusões e alianças entre grandes empresas que atuavam na internet, outra tendência no cenário externo que também teve seus reflexos no Brasil no começo dos anos 2000 (PANTOJA; FERREIRA, 2000).

\footnotetext{
${ }^{63}$ De acordo com dados apresentados pela ABRANET, o número de usuários desses serviços saltou de 250 mil em setembro de 1995 para 4 milhões em 1999 (PANTOJA, FERREIRA 2000, pg. 15).
} 
Como aponta Bolaño et al (2007), o modelo de união entre empresas da mídia tradicional com firmas que atuavam na internet, simbolizadas pelo emblemático caso AOL-Time Warner, também era desenhado no país, em escala menor, pela parceria Abril-UOL. Também foi notável, em junho de 2000, o acordo entre a Globo.com e a Telecom Itália, que pagou US\$ 810 milhões por 30\% do capital da empresa brasileira. A cifra representava, naquele ano, $20 \%$ do total de investimentos da operadora de telecomunicações no Brasil (LOBATO, 2002; TELECOM..., 2000). A aliança, que buscava prover serviços de internet sem fio e ampliar as operações do portal brasileiro para a comunidade hispânica, foi anunciado pelo CEO da operadora como "um passo vital na estratégia da Telecom Itália para o Brasil e a América Latina” (BIANCONI, 2000).

Como relatam os autores de "Economia Política da Internet" (2007), foi com este mesmo objetivo, de alcançar o público da América do Sul, que outras grandes empresas internacionais aportaram no Brasil nos anos 2000:

É o caso, por exemplo, da entrada do grupo StarMedia no Brasil, adquirindo os sites Cadê? e Zeek! e trazendo todo o know-how de quem já se consolidou como o maior grupo de serviços da internet na América Latina. É também o caso da entrada da espanhola Telefónica S/A, comprando o portal ZAZ para lançar o seu mega-portal Terra. Nos dois casos, os grupos, já atuantes em mais de um país, conseguiram vultuosas somas de recursos junto às bolsas de valores de Nova York (StarMedia e Terra/ZAZ) e Madri (Terra/ZAZ) (BOLAÑO et. al., 2007, p. 210).

Um retrato histórico da internet no Brasil na virada do milênio pode ser obtido por meio dos dados apresentados em "A evolução da Internet no Brasil e no mundo" e "Sociedade da Informação no Brasil - Livro Verde", publicados pelo então Ministério da Ciência e Tecnologia, em abril e setembro do ano 2000, respectivamente. Segundo dados apresentados nos documentos, o país dispunha naquele ano de 446.444 hosts, o que garantia a $13^{\mathrm{a}}$ colocação mundial em um ranking considerando o volume de hosts. O pódio era ocupado por Estados Unidos ( $1^{\circ}$ lugar, com 53,1 milhões de hosts), Japão ( $2^{\circ}$ lugar, 2,6 milhões) e Reino Unido ( $3^{\circ}$ lugar, 1,9 milhões de hosts) (PANTOJA; FERREIRA, 2000, p. 14). 
No que se refere ao número de domínios, o Brasil registrava 174.163 páginas. Conforme apresenta o gráfico 4, o maior crescimento de 1996 aos anos 2000 foi no número de páginas comerciais na internet brasileira.

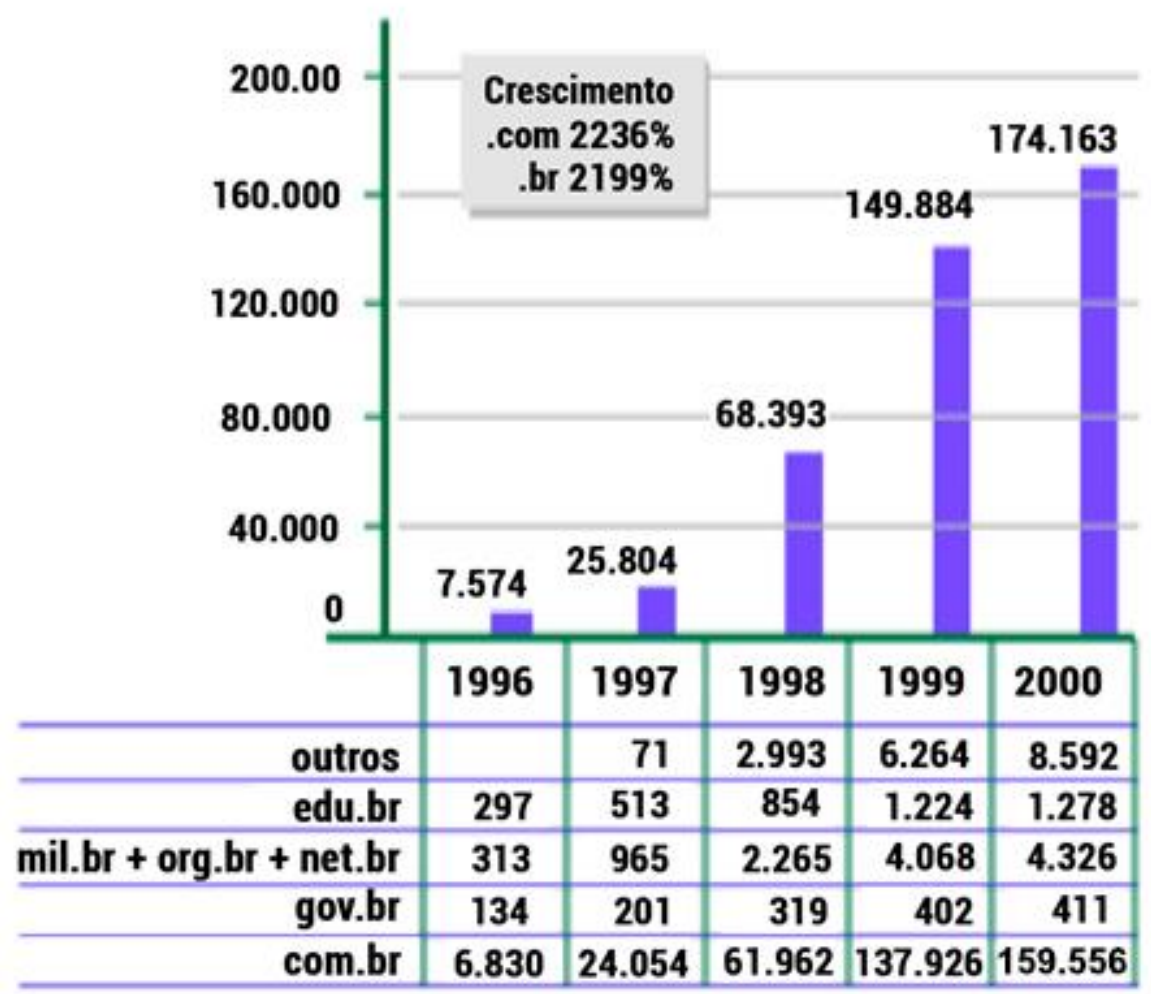

Gráfico 4 - Evolução do número de domínios de 1996 a 2000

Fonte: Fapesp

Feito este breve panorama histórico do desenvolvimento da internet até os anos 2000 no Brasil e no mundo será necessário, antes de avançar à análise do objeto de estudo desta dissertação, compreender o desenvolvimento recente da rede mundial de computadores. Este é o assunto que será tratado na próxima seção, que, ao final, apresenta um quadro contendo todos os eventos citados neste capítulo e outros dados secundários inseridos a título de contextualização histórica. 


\subsection{A fase mais recente do desenvolvimento da internet}

Para fins deste estudo, considera-se o quarto estágio do desenvolvimento da internet, seguindo a divisão proposta em Bolaño et. al. (2007), a fase inaugurada logo após o ano 2000 que se estende até os dias atuais. Nesse período, até 2015, o número de internautas saltou de 400 milhões $(2001)^{64}$ para 3,1 bilhões (2015), como se observa no gráfico a seguir:

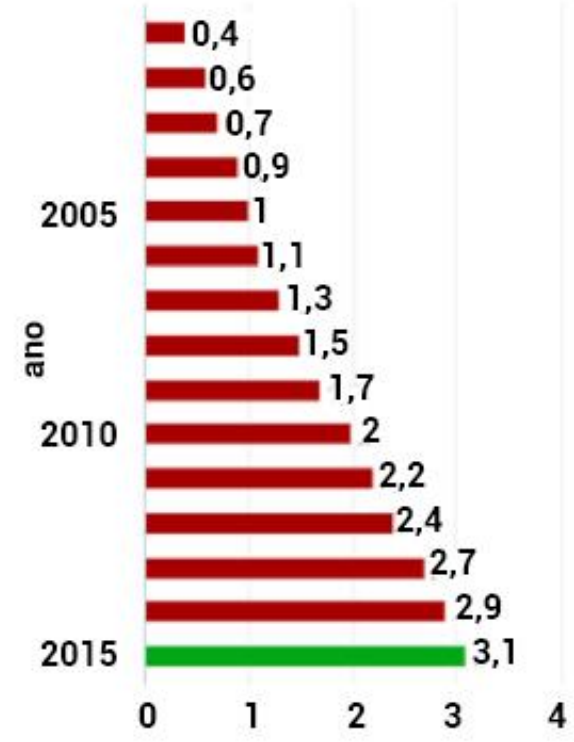

Gráfico 5 - Evolução do número de internautas 2000-2015 Fonte: União Internacional das Telecomunicações

Se nas transições das primeiras fases houve, como pontos de ruptura em relação ao estágio anterior, o surgimento de novas redes de comunicação (da primeira para a segunda fase) e a privatização da espinha dorsal da internet (da segunda para a terceira), particularizam o desenvolvimento da internet nos últimos quinze anos a popularização do acesso móvel à internet, o surgimento de sites de redes sociais e o avanço do comércio online.

\footnotetext{
${ }^{64}$ Como visto na seção 3.1, de acordo com estimativas da NUA Internet Surveys havia, no primeiro semestre do ano 2000, 275,54 milhões de pessoas conectadas no mundo.
} 
Em primeiro lugar, considerando o domínio das tecnologias de telecomunicações, em um sentido mais estrito, registra-se na quarta fase da internet o crescimento do uso de aparelhos celulares com banda larga móvel. Segundo a análise de Castells (2015), este foi o fator crítico para uma "nova onda da expansão da difusão da internet", ancorada também na construção da infraestrutura sem fio e da difusão da capacidade de banda larga avançada (p. 110)

Embora o primeiro celular com acesso à internet tenha sido criado ainda em $1996^{65}$, foi, de fato, a partir de 2010 que seu uso se expandiu entre os internautas. De acordo com estimativas da União Internacional das Telecomunicações (UIT), até o final de 2015, as assinaturas de banda larga móvel atingiram $47 \%$ da população do globo, um valor 12 vezes superior ao que era observado em $2007^{66}$. O número de aparelhos celulares chegou a sete bilhões, o que corresponde a uma taxa de penetração de $97 \%$, como demonstra o gráfico 6, que também apresenta as curvas de crescimento do uso individual da internet, da assinatura de banda larga fixa, do alcance da cobertura de rede $2 \mathrm{G}^{67}$ e de domicílios com acesso à internet.

\footnotetext{
${ }^{65}$ Em agosto de 1996, foi lançado na Finlândia o Nokia 9000, primeiro celular do mundo a oferecer acesso comercial à internet móvel (KLEINA, 2015). Com um teclado QWERTY em flip, o aparelho pesava cerca de 400 gramas e possuía memória de $8 \mathrm{MB}$. A imagem e as características gerais do produto podem ser visualizadas em <http://nokiamuseum.info/nokia-9000/>. Acesso em: 3 dez. 2016.

${ }^{66}$ Segundo dados da pesquisa TIC Domicílios, $47 \%$ dos brasileiros com 10 anos ou mais de idade acessaram a internet pelo aparelho em 2014 - o que corresponde a 81,5 milhões de pessoas. Em 2011, essa proporção era de 15\% (COMITÊ GESTOR DA INTERNET NO BRASIL, 2014).

${ }^{67} \mathrm{Os}$ termos $2 \mathrm{G}, 3 \mathrm{G}$ e $4 \mathrm{G}$ são designações dadas às gerações de telefonia móvel. O primeiro termo referese a tecnologia digital para aparelhos celulares que tem como foco principal as conexões de voz, podendo ainda prover conexões de dados com baixa velocidade. O $3 \mathrm{G}$, uma evolução do $2 \mathrm{G}$, passou a permitir a conexão de dados com maior velocidade e eficiência. Já a quarta geração de internet móvel, o 4G, oferece uma velocidade de conexão ainda maior a seus usuários. Tais explanações encontram-se disponíveis em <http://www.anatel.gov.br/consumidor/index.php/perguntas-frequentes?catid=1>. Acesso em: $1^{\circ}$ nov 2016.
} 


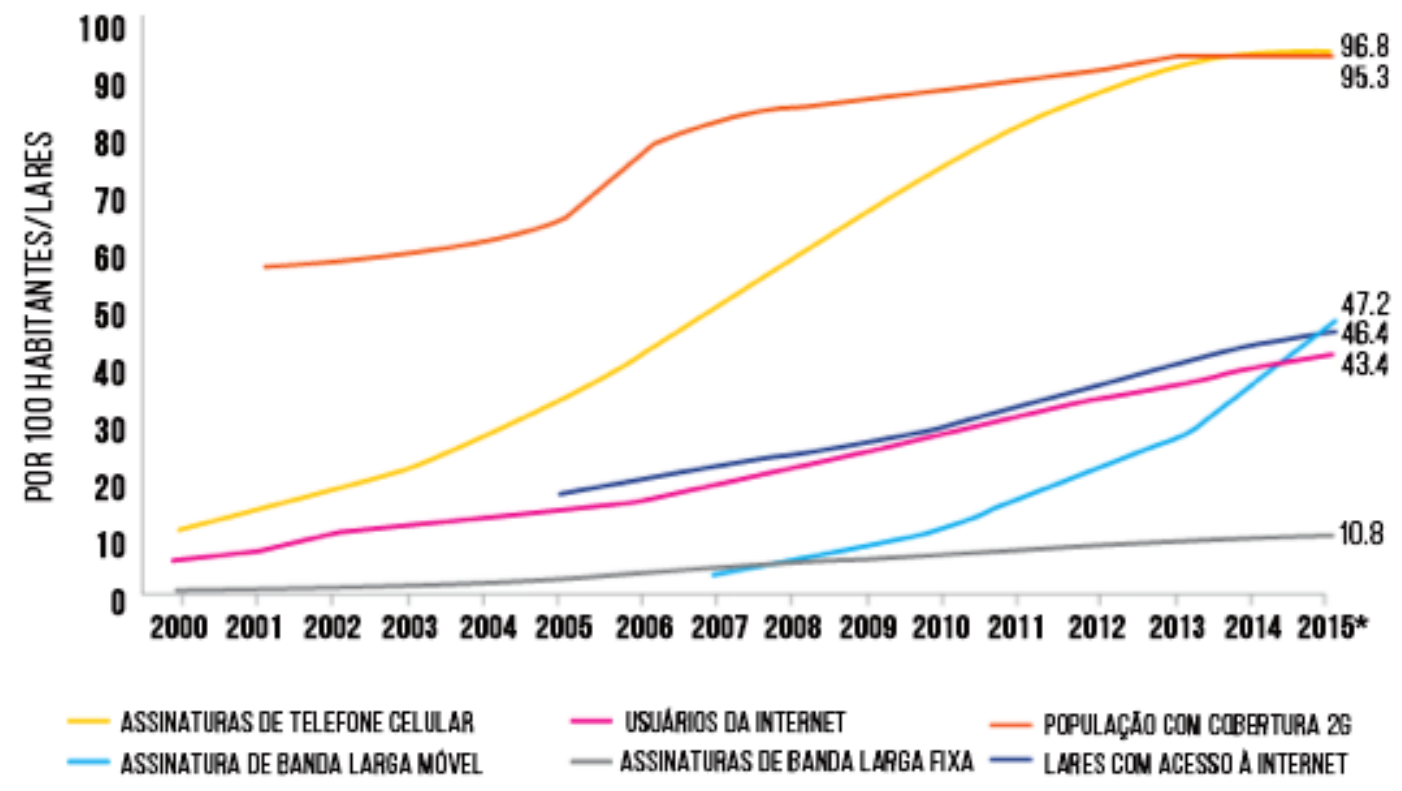

Gráfico 6 - Estimativas da população com cobertura de internet em 2015 Fonte: União Internacional das Telecomunicações

Já no que se refere e conteúdo e aplicações, uma das características centrais da quarta fase de desenvolvimento da internet, foi o surgimento de dezenas de sites de redes sociais ${ }^{68}$, tais como o Fotolog (2002), Linkedin, MySpace (lançados em 2003), Flickr, Facebook, Orkut (2004), Youtube (2005), Twitter (2006), Instagram (2010), Snapchat (2011), e de troca de mensagens instantâneas como o Whatsapp (2009) e Telegram (2013) ${ }^{69}$ (AOS 25..., 2015; CONHEÇA..., 2006; DAQUINO, 2012; ENTENDA..., 2012; GOMES, 2014; SALOMÃO, 2015).

\footnotetext{
${ }^{68}$ Segundo argumenta Recuero (2009), é necessário diferenciar "redes sociais" dos sites que as suportam: "Redes sociais na internet são constituídas de representações dos atores sociais e de suas conexões [...]. Enquanto a rede social é uma metáfora utilizada para o estudo do grupo que se apropria de um determinado sistema, o sistema, em si, não é uma rede social, embora possa compreender várias delas. Os sites que suportam redes sociais são conhecidos como "sites de redes sociais" (RECUERO, 2009, p. 2-3).

${ }^{69}$ Nos termos de Castells (2015), tais sites de redes sociais teriam contribuído para a "autocomunicação de massa". Segundo o autor, tal termo refere-se a uma nova forma histórica de comunicação em que é possível enviar mensagens e conteúdo "de muitos para muitos". Nas palavras de Castells, "é comunicação de massa porque tem o potencial de atingir um público global (...). Ao mesmo tempo, é autocomunicação porque a produção de mensagem é autogerada, a definição do(s) receptor(es) é autodirecionada e a recuperação das mensagens específicas, do conteúdo da World Wide Web (www) e de redes eletrônicas de comunicação é autosselecionada" (CASTELLS, 2015, p. 102).
} 
Tal como ocorreu nos anos 2000, as grandes companhias que operam na internet têm protagonizado na última década vultosos processos de integração, parcerias e fusões, asseverando a tendência à concentração percebida na terceira fase de desenvolvimento da internet. O Facebook, por exemplo, que registrou, em 2015, a marca de 1,59 bilhão de usuários, comprou o aplicativo de postagem de fotos Instagram em 2012 por US $\$ 750$ milhões e o serviço de troca de mensagens Whatsapp por US $\$ 22$ bilhões em $2014^{70}$ (FACEBOOK..., 2012; FACEBOOK..., 2016; PREÇO..., 2014). Outra empresa a realizar aquisições de grande porte nos últimos anos foi a operadora estadunidense de telecomunicações Verizon, que, em 2015, comprou a AOL em uma operação avaliada em US\$ 4 bilhões e, no ano seguinte, adquiriu por US\$4,83 bilhões o Yahoo, que, entre outros serviços, possuía um servidor de e-mails com mais de 225 milhões de usuários ativos por mês (VERIZON..., 2015; VERIZON..., 2016). A operadora de telefonia AT\&T anunciou, em outubro de 2016, a compra da Time Warner por US\$ 108 bilhões (AT\&T..., 2016).

Mas não são apenas as grandes corporações da internet que compõem esta complexa trama de compras, fusões e parcerias no ambiente digital. Em "O Poder da Comunicação" (2015), Castells apresenta, como se observa na figura 3 , as “interconexões” realizadas também com as empresas de mídia multinacionais que resultam na formação de "redes globais multimídias". O autor argumenta que "um dos objetivos dessas redes globais é a privatização e comercialização da internet para expandir e explorar novos mercados" (p. 121).

\footnotetext{
${ }^{70}$ Algumas das milionárias propostas de compra feitas por parte do Facebook também foram recusadas. Em 2008, os donos do Twitter recusaram uma oferta de US\$ 500 milhões para que o microblog passasse ao controle do Facebook. Em 2013, o criador do Snapchat se recusou a vender seu aplicativo por US\$ 3 bilhões (TWITTER..., 2011; JUNQUEIRA, 2014).
} 


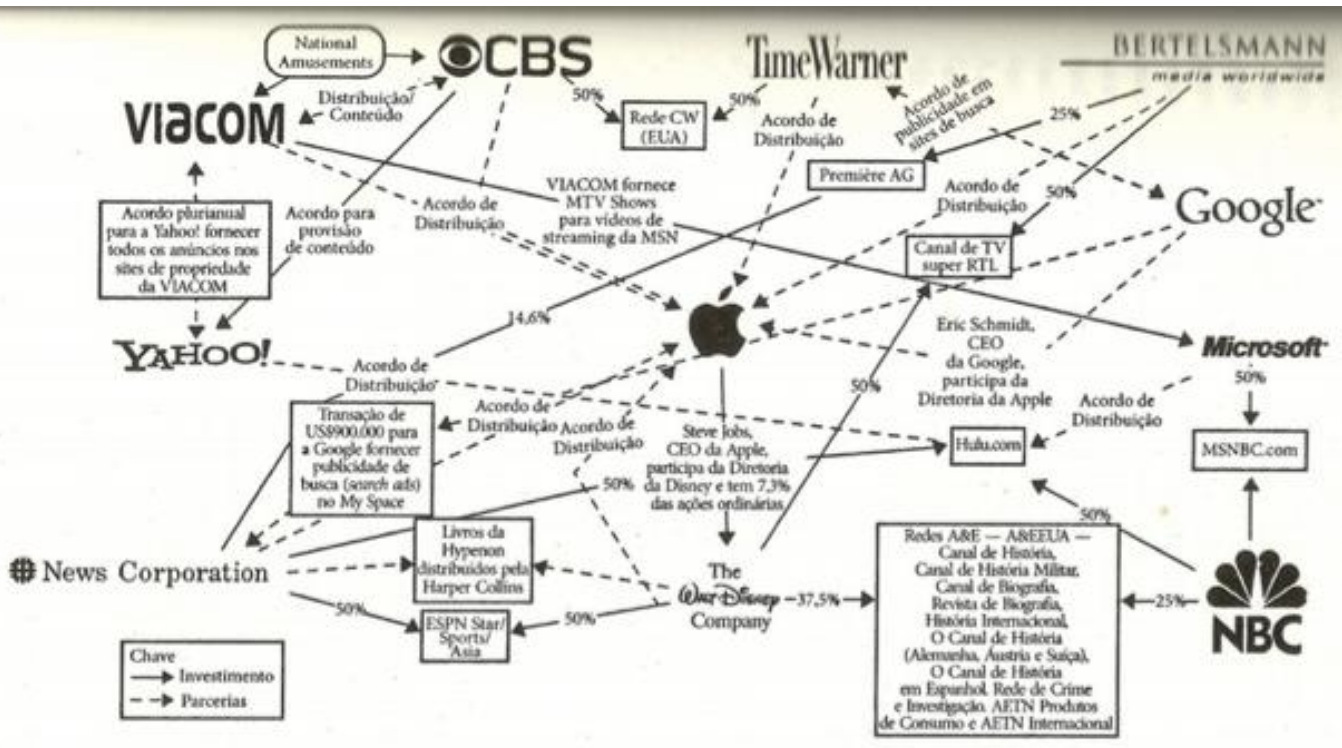

Figura 3 - Interconexões entre mídia multinacional e corporações da internet Fonte: Arsenault e Castells (2008), apresentada em Castells (2015)

A partir desse quadro desenhado por Castells, é necessário destacar dois importantes contextos a fim de fazer a correta contextualização da trajetória recente da internet. Em primeiro lugar, observa-se atualmente um complexo processo de digitalização de empresas midiáticas, particularmente na área do jornalismo, tema detalhadamente analisados em Bolaño et al. (2012). Em síntese, conforme argumentam os autores, a convergência tem provocado mudanças na organização dos mercados culturais, nas rotinas empresariais, na dinâmica do trabalho dos jornalistas (num processo de desqualificação, re-qualificação desses profissionais), nos formatos de financiamento e modelos publicitários. Advertem, no entanto, que,

Não se trata, evidentemente, de um processo determinado pela evolução tecnológica, ainda que esta cumpra um papel importante na mudança das relações de trabalho e da cultura profissional, sem a qual o processo não de completaria. Trata-se de um movimento perfeitamente inserido nas transformações por que passa o capitalismo (BOLAÑO et. al., 2012, p. 88).

Não menos importante, é preciso evidenciar na compreensão do fluxograma proposto por Castells o papel prestado pelas grandes corporações da internet em programas de vigilância e controle social. Um recente episódio pôs em xeque análises 
mais incautas a respeito do papel de tais empresas no cenário geopolítico mundial. Em junho de 2013, Edward Snowden, ex-técnico da agência estadunidense CIA (Central Intelligence Agency), entregou a jornalistas do The Guardian e do Washington Post documentos que detalhavam programas de vigilância em massa realizados pela Agência Nacional de Segurança (NSA, na sigla em inglês) a pretexto de evitar atentados terroristas nos Estados Unidos.

Por meio do programa intitulado "Prism", por exemplo, a NSA tinha acesso direto a servidores do Google, Facebook, Apple, Microsoft, Yahoo, Youtube, Skype, AOL, entre outras grandes corporações da internet, e conseguia coletar o histórico de busca dos usuários dessas empresas, e-mails, arquivos transferidos, conversas de batepapo em tempo real, além de outros conteúdos de comunicações pessoais. No documento da NSA revelado pelo The Guardian, a agência alegava que o "Prism" foi introduzido para superar deficiências da FISA (Foreign Intelligence Surveillance Act), lei federal que prevê procedimentos de vigilância física e eletrônica no território estadunidense de cidadãos suspeitos de espionagem ou terrorismo. O mesmo documento destacava que os Estados Unidos têm uma "vantagem" para executar o "Prism" pelo fato de abrigar empresas e grande parte da infraestrutura responsável pela arquitetura da internet (GREENWALD; MACASKILL, 2013)

Snowden revelou ainda a existência do programa chamado "XKeystore", o sistema de espionagem de maior alcance da NSA. De acordo com informações publicadas no The Guardian, por meio deste programa os analistas da agência de inteligência estadunidense acessam "quase tudo que um usuário típico faz na internet”: o conteúdo de e-mails, histórico de navegação, browser utilizado, atividades em sites de rede social, entre outras informações. As buscas no sistema podem ser obtidas através dos nomes completos ou apelidos dos alvos da NSA, endereços IPs, telefones e palavras-chave em diversas redes sociais e provedores de e-mail. O monitoramento ocorre em diversas escritórios da agência estadunidense no mundo, uma delas situada Brasília. Conforme revelou o The Guardian, para extrair os dados dos internautas por meio do "XKeystore" não era necessária uma autorização judicial - bastava ao técnico da NSA preencher um formulário online apresentando uma justificativa genérica para sua pesquisa (GREENWALD, 2013). 
À época, em resposta à repercussão do escândalo, que tomou proporções globais, o governo estadunidense alegou que as medidas tomadas pela NSA faziam parte de uma estratégia de prevenção a ataques terroristas, minimizando, entre outros aspectos polêmicos da questão, o fato de que foram recolhidas informações privadas de autoridades e líderes políticos mundiais, tais como a chanceler alemã Angela Merkel e a presidente do Brasil, Dilma Rousseff ${ }^{71}$ (EUA..., 2013).

Destaca-se ainda nesta última fase do desenvolvimento da internet o avanço no volume dos negócios e vendas realizados em ambiente online, algo inaugurado, como visto anteriormente, ainda na terceira fase de desenvolvimento da rede mundial de computadores. O resultado do comércio eletrônico em nível mundial saltou de US\$ 1,03 trilhões em 2011 para US\$ 1,93 trilhões em 2014. Estima-se que a apuração dos resultados de 2015 indiquem que o setor tenha somado US\$ 2,24 trilhões, de acordo com dados da E-commerce Foundation (FONSECA; LOPES, 2016, p.13). No Brasil, de acordo com dados da consultoria E-bit em parceria com a Buscapé Company, o faturamento do e-commerce subiu de US\$ 18,7 bilhões em 2011 para US $\$ 41,3$ bilhões em 2015 (E-BIT/BUSCAPÉ COMPANY, 2016, p. 30).

Por fim, como grandes tendências que já despontam na quarta fase de desenvolvimento da internet, destaca-se na trajetória o desenvolvimento do Big Data e da Internet das Coisas. O primeiro termo refere-se ao conjunto de ferramentas e tecnologias capazes de interpretar informações não estruturadas, geradas a partir de postagens em redes sociais, GPS, câmeras e outros sensores utilizados por internautas. A partir da leitura de um grande volume de dados digitais disponíveis, organizações

\footnotetext{
${ }^{71}$ Em setembro de 2013 a presidente Dilma Rousseff cancelou uma viagem oficial que faria aos Estados Unidos no mês seguinte. Segunda nota divulgada pela Secretaria de Imprensa da Presidência da República, o adiamento teria sido acordado com o presidente dos Estados Unidos, Barack Obama, para evitar que os resultados oficiais da visita oficial de Estado ficassem "condicionados a um tema cuja solução satisfatória ao Brasil ainda não foi alcançado". Em outro trecho, a nota condenou a espionagem realizada pela NSA que, no caso brasileiro, monitorou conversas de integrantes do governo e dados da Petrobras: “ [...] As práticas ilegais de interceptação das comunicações e dados de cidadãos, empresas e membros do governo brasileiro constituem fato grave, atentatório à soberania nacional e aos direitos individuais, e incompatível com a convivência democrática entre países amigos. Tendo em conta a proximidade da programada visita de Estado a Washington - e na ausência de tempestiva apuração do ocorrido, com as correspondentes explicações e o compromisso de cessar as atividades de interceptação - não estão dadas as condições para a realização da visita na data anteriormente acordada. (...)" (MONTEIRO, 2013).
} 
comerciais e empresas podem, por exemplo, traçar estratégias de operação de venda mais acertadas, prevendo o comportamento dos consumidores de seus serviços.

Já o termo Internet das Coisas (IoT, na sigla em inglês) ${ }^{72}$ é a designação dada a objetos, dispositivos, eletrodoméstico e até mesmo vestimentas conectadas à internet ${ }^{73}$. Um dos exemplos mais icônicos da integração de objetos à rede mundial de computadores foi o Google Glass, que começou a ser vendido ao público em 2014. Acoplado a um minicomputador, microfone, câmera e tela sensível ao toque, os óculos permitiam a seus usuários fotografar, filmar, enviar dados pela internet e acessar um navegador GPS (Sistema de Posicionamento Global, em português), entre outras funções. No ano seguinte, o aparelho, que custava cerca de R 33 mil, foi retirado do mercado, sendo oferecido agora somente a empresas e desenvolvedores (BILTON, 2015; HAMANN, 2012; GOOGLE..., 2015).

Ainda no quadro de grandes inovações tecnológicas, deve-se registrar, por fim, as pesquisas e testes levados a cabo recentemente para realizar conexões à internet a partir do espaço. Desde 1998, a NASA tem investido em um programa que pretende criar uma "internet interplanetária", em parceria com um dos fundadores do protocolo TCP/IP, Vinton Cerf. Em 2008, a agência testou com sucesso o uso de um software chamado Disruption-Tolerant Networking (DTN), que é inspirado no protocolo $\mathrm{TCP} / \mathrm{IP}^{74}$. Por meio dele, uma nave espacial da NASA localizada a 32 milhões de quilômetros da Terra enviou e recebeu dezenas de imagens do espaço. Oito anos depois, em 2016, a NASA instalou o sistema de comunicação DNT na Estação Espacial Internacional. De acordo com a agência estadunidense, a expectativa é que a instalação de uma internet interplanetária facilite missões espaciais e permita, num futuro

\footnotetext{
${ }^{72} \mathrm{O}$ termo "Internet das Coisas" foi cunhado por Kevin Ashton do Massachusetts Institute of Technology (MIT) em 1999 (CRIADOR..., 2015).

${ }^{73}$ Recentemente, em 2016, a poucos dias da abertura dos Jogos Olímpicos, a Cisco e outras empresas de tecnologia montaram na cidade do Rio de Janeiro um laboratório de IoT, em parceria com a prefeitura carioca. Entre outros serviços apresentados à população, foram instalados "bueiros conectados", com soluções tecnológicas para impedir entupimentos, e postes com microfones integrados, capazes de processar ruídos e enviar sinais de alerta para autoridades de segurança caso fosse identificada alguma situação de emergência (PAIVA, 2016d; PAIVA, 2016f).

${ }^{74}$ Diferente do protocolo TCP/IP, o Disruption-Tolerant Networking ("Redes tolerantes a atraso e desconexão" em português) consegue armazenar pacotes parciais de dados ao longo de um caminho de comunicação, até que as partes possam ser encaminhadas ou retransmitidas e então reempacotadas no destino final - que pode ser uma estação na Terra ou uma nave espacial. Segundo a NASA, esse método utilizado pelo DTN pode ser comparado a jogadores de basquete, que arremessam a bola com segurança ao jogador mais próximo até alcançarem a cesta (BROWN et al., 2016; NEW..., 2016).
} 
próximo, comunicações de astronautas desde a superfície da lua (BROWN et al., 2008; NEW..., 2016). 


\section{O PROCESSO DE AUTOMAÇÃO BANCÁRIA E OS INTERESSES DOS BANCOS NO DESENVOLVIMENTO DA INTERNET}

Este terceiro capítulo está dividido em três seções. A primeira apresenta o contexto histórico do objeto de estudo desta dissertação, o processo de automação bancária no Brasil. Como será evidenciado a seguir, os eventos ligados à informatização dos bancos no país ocorreram a partir dos anos 1960 e se intensificaram na década seguinte - antecederam, portanto, em mais de vinte anos o estabelecimento da internet comercial no país. A seção pretende apresentar as principais inovações tecnológicas desenvolvidas para os bancos e, em linhas gerais, os fatos mais importantes no cenário político e macroeconômico de cada década da trajetória da automação bancária no país.

Em seguida, a segunda seção analisará, em destaque, as duas paradigmáticas e pioneiras ações do Bradesco no âmbito da internet brasileira, as ofertas de conexão gratuitas apresentadas pelo banco a seus correntistas em 1999 e 2014. Tais iniciativas do Banco inserem-se, cada uma, em um amplo quadro de inovações, tendências e rupturas no cenário tecnológico e econômico. Na perspectiva teórica da Economia Política da Comunicação, os dois casos funcionam como ponto de partida para compreender a trama de atores, interesses e articulações envolvidas na estratégia do Bradesco em cada oportunidade.

A terceira seção do capítulo resgata o debate a respeito da internet grátis, apontando o debate a respeito da neutralidade de rede e da permissibilidade dos chamados planos de Zero Rating, apresentados no capítulo dois. Busca-se com isso iluminar o mais recente ponto de conexão existente entre a trajetória da informatização dos processos bancários e o desenvolvimento da internet no país ${ }^{75}$.

Antes, porém, de avançar na apresentação dessas três seções, é necessário introduzir, em linhas gerais, o funcionamento do Sistema Financeiro Nacional. Para

\footnotetext{
75 Os fatos e eventos relacionados à informatização dos bancos (citados neste capítulo) e ao desenvolvimento da internet (apontados no capítulo três) foram reunidos numa cronologia, disposta no apêndice da dissertação.
} 
isso são utilizadas informações e dados contidos no sítio do Banco Central do Brasil $(\mathrm{BACEN})^{76}$.

O mercado financeiro pode ser entendido, de forma simplificada, como um conjunto de instituições e instrumentos financeiros que visam transferir recursos de agentes econômicos superavitários para os deficitários. No Brasil, o Sistema Financeiro Nacional (SFN) é composto por três diferentes ramos (Moeda, crédito, capital e câmbio, Seguros privados e Previdência fechada e) que apresentam, conforme ilustra a tabela 4, órgãos normativos, órgãos supervisores e operadores distintos.

Tabela 4 - Organização do Sistema Financeiro Nacional

\begin{tabular}{|c|c|c|c|}
\hline \multicolumn{2}{|c|}{ Moeda, crédito, capital e câmbio } & \multirow{2}{*}{$\begin{array}{c}\text { Seguros privados } \\
\text { CNSP } \\
\text { Conselho Nacional de } \\
\text { Seguros Privados }\end{array}$} & \multirow{2}{*}{$\begin{array}{c}\text { Previdência } \\
\text { Fechada } \\
\text { CNPC } \\
\text { Conselho Nacional de } \\
\text { Previdência } \\
\text { Complementar }\end{array}$} \\
\hline ڤై & $\begin{array}{c}\text { CNM } \\
\text { Conselho Monetário Nacional }\end{array}$ & & \\
\hline 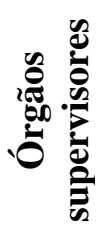 & $\begin{array}{c}\text { BCB } \\
\text { Banco Central do Brasil } \\
\text { CVM } \\
\text { Comissão de Valores Mobiliários }\end{array}$ & $\begin{array}{c}\text { Susep } \\
\text { Superintendência de } \\
\text { Seguros Privados }\end{array}$ & $\begin{array}{c}\text { Previc } \\
\text { Superintendência } \\
\text { Nacional de } \\
\text { Previdência } \\
\text { complementar }\end{array}$ \\
\hline 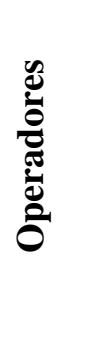 & $\begin{array}{c}\text { - Bancos e Caixas Econômicas } \\
\text { - Administradoras de Consórcio } \\
\text { • Bolsa de Valores } \\
\text { • Cooperativas de crédito } \\
\text { - Corretoras e Distribuidoras } \\
\text { - Bolsa de Mercadorias e de futuro } \\
\text { - Instituições de Pagamento } \\
\text { - Demais Instituições não Bancárias }\end{array}$ & $\begin{array}{c}\text { - Seguradoras e } \\
\text { Resseguradores } \\
\text { - Entidades abertas de } \\
\text { previdência }\end{array}$ & $\begin{array}{c}\text { - Entidades fechadas } \\
\text { de previdência } \\
\text { complementar } \\
\text { (fundo de pensão) }\end{array}$ \\
\hline
\end{tabular}

Fonte: BACEN; adaptado pela autora

Para fins deste estudo, interessa examinar os órgãos, entidades e instituições que compõe a primeira coluna dessa tabela, o ramo da Moeda, crédito, capital e câmbio,

\footnotetext{
${ }^{76}$ Os materiais consultados para o desenvolvimento desta seção do capítulo estão disponíveis em: $<$ http://www.bcb.gov.br/pt-br/Paginas/default.aspx\#!/n/SFN>;

<http://www.bcb.gov.br/Pre/bcUniversidade/Palestras/Palestra_SFN_04062013_Furlani.pdf > e

< http://www.bcb.gov.br/pre/composicao/composicao.asp >. Acesso em: 14 nov. 2016.
} 
onde se situam os bancos comerciais, entre eles o Bradesco. Cada um dos quatro mercados abrangidos por este ramo desempenha funções distintas na ordem do sistema financeiro:

(i) Mercado monetário: é responsável por fornecer à economia papelmoeda e moeda escritural, aquela depositada em conta-corrente;

(ii) Mercado de crédito: é o mercado fornecedor de recursos para o consumo das pessoas em geral e para o funcionamento das empresas;

(iii) Mercado de capitais: o que permite às empresas em geral captar recursos de terceiros e, portanto, compartilhar os ganhos e os riscos;

(iv) Mercado cambial: é o mercado onde há compra e venda de moeda estrangeira.

O órgão normativo deste ramo do SFN, o Conselho Monetário Nacional (CNM), criado pela Lei $\mathrm{n}^{\circ}$ 4.595, de 31 de dezembro de 1964, e instituído em 31 de março de 1965, é responsável por formular a política da moeda e do crédito, objetivando a estabilidade da moeda e o desenvolvimento econômico e social do país. Suas orientações são executadas pelo BACEN, criado pela mesma Lei, e que tem, dentre outras atribuições, a competência de emitir papel-moeda e moeda metálica, exercer o controle de crédito, autorizar o funcionamento das instituições financeiras e controlar o fluxo de capital estrangeiro no país.

O outro órgão supervisor do ramo de Moeda, crédito, capital e câmbio, a Comissão de Valores Mobiliários (CVM), foi criado somente no ano de 1976, com o objetivo de fiscalizar, normatizar, disciplinar e desenvolver o mercado de valores mobiliários no Brasil. Tem como atividades principais garantir a lisura nas operações de compra e venda de valores mobiliários, promover a expansão do mercado acionário e proteger os investidores.

Analisando o quadro de instituições que operam neste ramo do SFN, é possível agrupá-las em sete subsistemas operativos: (i) Instituições financeiras bancárias, composto por caixas econômicas, bancos comerciais, cooperativas de crédito e bancos múltiplos; (ii) Instituições financeiras não bancárias, composto por bancos de investimento, bancos de desenvolvimento, bancos de câmbio, sociedades de arrendamento mercantil (leasing) e sociedades de crédito, financiamento e investimentos (financeiras), agências de fomento ou de desenvolvimento, entre outros; 
(iii) Instituições financeiras de natureza especial, onde se situam, entre outros, Banco do Brasil, Caixa Econômica Federal e Banco Nacional do Desenvolvimento Econômico e Social (BNDES); (iv) Sistema brasileiro de poupança e empréstimo, composto por caixas econômicas, sociedades de crédito imobiliário, associações de poupança e empréstimo; (v) Sistema de distribuição de títulos e valores mobiliários, onde se encontram as sociedades corretoras de câmbio, as sociedades corretoras, as distribuidoras de valores mobiliários e os agentes autônomos de investimento; (vi) Câmaras prestadoras de serviço de registro, de liquidação e de compensação, compostas por bolsas de valores, de mercadorias e de futuros e outras entidades; e, por fim, (vii) Administradores de recursos de terceiros, onde se agrupam os fundos mútuos de investimento, os clubes de investimento, os administradores de consórcio e os planos individuais de aposentadoria e pensão.

É, portanto, no primeiro subsistema do ramo de Moeda, crédito, capital e câmbio, o das Instituições Bancárias, que residem as questões afetas ao desenvolvimento desta dissertação. Para melhor compreender e situar os dois casos em que o Bradesco ofertou internet grátis no país, em 1999 e 2014, cumpre apresentar, de passagem, alguns dados e características estruturais do sistema bancário brasileiro.

Em primeiro lugar, deve-se destacar o amplo alcance do atendimento bancário no país. De acordo com dados do Banco Central, a taxa de bancarização, que leva em conta o cadastro de clientes do Sistema Financeiro Nacional e o acesso a serviços essenciais, que englobam, para contas correntes, cartão inicial com função débito, saque e extrato mensal, chegou a 89,6\% no ano de 2015 (FEDERAÇÃO BRASILEIRA DE BANCOS, 2015). O índice vem crescendo de maneira estável nos últimos anos: em 2010 era de 77,8\%; em 2011, 79,9\%; em 2012, 82,8\%; em 2013, 85,4\%; e, em 2014, $87 \%$.

Com relação à composição do mercado bancário, havia no país, em dezembro de 2015, 1.863 instituições autorizadas a atuar no Sistema Financeiro Nacional. Desse total, havia $154^{77}$ bancos: 10 públicos e 144 privados (somados os nacionais, os

\footnotetext{
${ }^{77}$ De acordo com o Banco Central, do total, sete são instituições de grande porte, 45 de médio porte e 102 de porte pequeno ou micro. As informações estão disponíveis em: <http://www.bcb.gov.br/htms/deorf/r201512/T4OD_Quadro\%2015\%20\%20Institui\%C3\%A7\%C3\%B5es\%20do\%20segmento\%20banc\%C3\%A1rio\%20por\%20porte.pdf>. Acesso em: 25 set. 2016.
} 
nacionais com participação estrangeira, os de controle estrangeiro e os estrangeiros). Por segmento, eram 132 bancos múltiplos, 21 comerciais e a Caixa Econômica Federal $^{78}$.

Embora tais números pareçam à primeira vista bastante elevados, parte da literatura especializada considera o setor bancário brasileiro concentrado e pouco competitivo (NAKANE, 2001; BELAISCH, 2003; 2003; ARAÚJO; NETO; PONCE, 2006;). Conforme demonstram Araújo, Neto e Ponce (2006), por meio da aplicação de quatro modelos matemáticos ${ }^{79}$, ainda que não se configure um cenário de monopólio no Brasil, é possível afirmar que os agentes econômicos do setor bancário brasileiro atuam em regime de concorrência monopolística. Uma das evidências empíricas mobilizadas pelos autores é a concentração de ativos ${ }^{80}$ nas mãos de um pequeno grupo de bancos.

Em junho de 2016, as dez maiores instituições de acordo com esse critério concentravam um total de $\mathrm{R} \$ 7,16$ trilhões em ativos. O Bradesco ${ }^{81}$ ocupava o quarto lugar nesse ranking e, entre as instituições privadas, era o segundo maior banco em

$78 \mathrm{O}$ quantitativo de instituições autorizadas por segmento pode ser visualizado em: $<$ http://www.bcb.gov.br/htms/deorf/r201512/T1ES_Quadro\%2001\%20\%20Quantitativo\%20de\%20institui\%C3\%A7\%C3\%B5es\%20autorizadas\%20a\%20funcionar.pdf>. Já o quantitativo de banco por origem de capital está disponível em: <http://www.bcb.gov.br/htms/deorf/r201512/T4OD_Quadro\%2013\%20$\%$ 20Quantitativo $\% 20$ de $\% 20$ bancos $\% 20$ por $\% 20$ origem $\% 20$ de $\% 20$ capital.pdf $>$. Acesso em: 25 set. 2016.

${ }^{79}$ Em "Competição e Concentração entre os Bancos Brasileiros" (2006), os autores utilizam os Índices de Herfundahl-Hirschman (HHI), de Hall-Tideman (HTI) e de Entropia de Theil (T) para calcular a concorrência bancária e o Modelo Panzar-Rosse para medir a concorrência do mercado brasileiro.

${ }^{80}$ De acordo com a Resolução n ${ }^{\circ} 3.534$ do Banco Central, de 31 de agosto de 2008, que define termos relacionados a instrumentos financeiros para fins de registro contábil, considera-se ativo financeiro: “a) dinheiro; b) instrumento de capital próprio de outra entidade; c) direito contratual de (1) receber dinheiro ou outro ativo financeiro de outra entidade ou (2) trocar ativos financeiros ou passivos financeiros com outra entidade em condições que sejam potencialmente favoráveis à própria entidade; d) contrato a ser ou que possa ser liquidado com instrumento de capital próprio da entidade e que seja (1) instrumento financeiro não-derivativo para o qual a entidade esteja ou possa estar obrigada a receber um número variável de instrumentos de capital da própria entidade ou (2) instrumento financeiro derivativo a ser ou que possa ser liquidado por outra forma que não pela troca de um valor fixo em dinheiro ou outro ativo financeiro por um número fixo de instrumento de capital próprio da entidade".

${ }^{81} \mathrm{O}$ Bradesco foi fundado por Amador Aguiar em 10 de março de 1943 na cidade de Marília (São Paulo). Costa (2014) relata que Aguiar, típico self-made man da década de 1940, não tinha como estratégia inicial em seu empreendimento bancário atrair barões do café ou empresário da indústria açucareira do interior paulista, mas sim pessoas de posses modestas, como colonos, comerciantes, pequenos agricultores e funcionários públicos. Segundo o autor, "este estilo de exploração de mercado de massas antecipava-se ao ciclo de massificação do capitalismo, com popularização dos negócios” (COSTA, 2014, p. 227). 
ativos, atrás apenas do Itaú, que registrava no período $\mathrm{R} \$ 1,2$ trilhões em ativos, como é possível observar abaixo.

Tabela 5 - Maiores bancos brasileiros em número de ativos

\begin{tabular}{lc}
\hline \multicolumn{1}{c}{ INSTITUIÇÃO } & ATIVO TOTAL \\
\hline Banco do Brasil & 1.482 .569 .850 \\
Itaú & 1.324 .027 .104 \\
Caixa Econômica Federal & 1.214 .034 .280 \\
Bradesco & 955.953 .603 \\
BNDES & 939.613 .054 \\
Santander & 660.052 .151 \\
BTG Pactual & 197.303 .326 \\
HSBC & 151.149 .582 \\
Safra & 135.900 .066 \\
Votorantim & 108.091 .841 \\
\hline
\end{tabular}

Fonte: BACEN; elaborada pela autora

A partir da análise da série histórica " 50 maiores bancos" $" 82$, disponibilizada pelo Banco Central, é possível concluir que essa tendência à concentração de ativos não é, no entanto, uma novidade no cenário doméstico. Em 1995, os seis maiores bancos do país (grupo formado à época por Caixa Econômica Federal, Banco do Brasil, Banespa, Bradesco, Unibanco e Itaú) concentravam $60,5 \%$ do total de ativos de todos os bancos com operações comerciais. Em 2014, o grupo das seis maiores instituições (Banco do Brasil, Itaú, Caixa Econômica Federal, Bradesco, Santander e HSBC) passou a deter $82,5 \%$ do total de ativos.

\footnotetext{
${ }^{82}$ Os levantamentos de dados da série histórica "50 maiores bancos e consolidado do Sistema Financeiro" foram realizadas de 1995 a 2014 e estão disponíveis em <http://www4.bcb.gov.br/top50/port/top50.asp>. Acesso em: 24 set. 2016. 
Tabela 6 - Os seis maiores bancos em ativos em 1995 e em 2014

\begin{tabular}{|c|c|c|c|}
\hline \multicolumn{2}{|l|}{1995} & \multicolumn{2}{|c|}{2014} \\
\hline Instituição & Ativos em R\$ & Instituição & Ativos em R\$ \\
\hline CEF & 80.413 .061 & Banco do Brasil & 1.324 .464 .414 \\
\hline Banco do Brasil & 79.854 .753 & Itaú & 1.117 .848 .197 \\
\hline Banespa & 49.143 .477 & CEF & 1.064 .674 .796 \\
\hline Bradesco & 28.847 .096 & Bradesco & 883.438 .773 \\
\hline Unibanco & 22.290 .730 & Santander & 598.224 .807 \\
\hline Itaú & 19.616 .485 & HSBC & 167.971 .558 \\
\hline $\begin{array}{l}\text { Total de ativos dos seis } \\
\text { maiores bancos }\end{array}$ & 280.165 .602 & $\begin{array}{l}\text { Total de ativos dos seis } \\
\text { maiores bancos }\end{array}$ & 5.156 .622 .545 \\
\hline $\begin{array}{l}\text { Total ativos dos bancos } \\
\text { com operaç̃̃es } \\
\text { comerciais }\end{array}$ & $\begin{array}{c}424.548 .753 \\
\text { (144 instituições) }\end{array}$ & $\begin{array}{l}\text { Total ativos dos bancos } \\
\text { com operações comerciais }\end{array}$ & $\begin{array}{c}6.249 .548 .684 \\
\text { (96 instituições) }\end{array}$ \\
\hline $\begin{array}{l}\text { Participação dos seis } \\
\text { maiores bancos }\end{array}$ & $60,52 \%$ & $\begin{array}{l}\text { Participação dos seis } \\
\text { maiores bancos }\end{array}$ & $82,5 \%$ \\
\hline
\end{tabular}

Fonte: BACEN; elaborada pela autora

Um dos fatores que teria levado à concentração do sistema bancário brasileiro a partir de meados dos anos noventa foi o lançamento do Plano Real, em julho de 1994 (CYSNE; COSTA, 1997; SANTOS, 2004; SMANIOTTO; ALVES, 2016). Isso porque, como explica parte da literatura especializada, com a estabilização econômica do país e a redução considerável da inflação, de $40 \%$ ao mês no período pré-plano a uma média de 3,65\% (IGP-DI) de julho de 1994 a maio de 1995 (CYSNE; COSTA, 1997), houve redução dos ganhos bancários com as oscilações inflacionárias. Com isso, de julho de 1994 a dezembro de 1995, o país registro 24 casos de insolvência bancária ${ }^{83}$ (CYSNE; COSTA, 1997) e se deflagrou um quadro de privatizações, fusões e incorporações de bancos públicos e privados no Brasil.

Outro fator que contribuiu para o cenário de incorporações e consequente concentração do setor foi o ingresso de bancos estrangeiros (SMANIOTTO; ALVES, 2016). Como explica Freitas (2011), havia no cenário mundial, em meados da década de noventa, um conjunto de fatores que deu início a um movimento de

\footnotetext{
${ }^{83}$ De acordo com dados apresentados pelos autores, dos 24 bancos insolventes, 15 sofreram liquidação extrajudicial, 6 passaram por um regime de administração especial temporária e 3 sofreram intervenção.
} 
internacionalização de bancos estrangeiros. Por um lado, grandes instituições capitalistas tinham interesse em aumentar seus lucros, após a retração econômica na década de 1980, ampliando suas atividades em outros países e, por outro lado, autoridades financeiras de diversos países, seguindo orientações de organismos multilaterais tais como a OCDE, o FMI e a $\mathrm{OMC}^{84}$, passaram a abolir ou flexibilizar as restrições existentes para que bancos estrangeiros entrassem em operação em seus mercados domésticos. A presença dos atores internacionais era vista como uma forma de modernizar os sistemas financeiros e, ao inserir novos agentes no mercado, estimular a concorrência.

No Brasil, a abertura financeira iniciada no Governo de Collor de Mello se aprofundou no mandato de Fernando Henrique Cardoso. De acordo com dados apresentados por Freitas (2011), havia um total de 38 bancos estrangeiros no Brasil em 1995. Seis anos mais tarde, em 2001, esse número já chegava a 72. A partir desse ano, no entanto, começou a se registrar a saída dos operadores estrangeiros no Brasil. Em 2002, último ano de FHC na Presidência da República, eram 65 bancos de outros países atuando aqui. Em 2009, o número já chegava a $54^{85}$.

Entre os bancos que deixaram de operar nos últimos anos, estão o americano Bank of America, o espanhol Banco Bilbao Vizcaya Argentina SA, o italiano Intesa Sanpaolo SA e o francês Credit Lyonnais SA (MARCELINO, 2016). Mais recentemente foi a vez do HSBC sair do mercado brasileiro. Em julho de 2016, foi concluído o processo de compra do banco inglês pelo Bradesco. Segundo informações divulgadas por este, o processo de aquisição custou R $\$ 16$ bilhões e aumentou em $15,9 \%$ os ativos do Bradesco, que passariam a somar R \$ 1,27 trilhões (BRADESCO..., 2016).

O cenário, e o quadro mais amplo da América Latina, foi avaliado pelo Fundo Monetário Internacional em um detalhado relatório publicado em março de 2016 (INTERNATIONAL MONETARY FUND, 2016). Para os especialistas do FMI, a saída de grandes bancos internacionais da região deve-se, entre outros motivos, a

\footnotetext{
${ }^{84}$ Siglas para Organização de Cooperação e Desenvolvimento Econômico, Fundo Monetário Internacional e Organização Mundial do Comércio, respectivamente.

${ }^{85}$ Freitas (2011) considera em sua análise as subsidiárias de instituições financeiras (bancos múltiplos ou comerciais com controle estrangeiro) e as filiais ou sucursais de bancos estrangeiros que são extensão da matriz no exterior.
} 
reflexos da crise financeira internacional de 2008, que tem feito as grandes instituições reduzirem suas operações ou deixarem de operar em países latino-americanos. De acordo com o documento, que defende a integração financeira do continente, tal movimento implicará no aumento da concentração dos sistemas bancários domésticos e a ampliação da atuação regional de instituições de países como o Brasil $^{86}$ e a Colômbia.

Dado esse panorama da organização atual do Sistema Financeiro Nacional e algumas das características mais gerais do setor bancário brasileiro, é oportuno passar a examinar o contexto histórico que envolve o objeto de estudo desta dissertação, o processo de automação bancária.

\subsection{Automação bancária no Brasil}

O processo de informatização dos bancos no Brasil é considerado uma referência nacional e internacional (DINIZ; MEIRELLES; FONSECA, 2010). Muitas das soluções tecnológicas desenvolvidas no país na década de setenta foram exportadas para outros sistemas bancários (DANTAS, 1988; DANTAS, 1989). O banco Bradesco, muito antes de lançar no mercado as ofertas de internet grátis em 1999 e 2014, desempenhou um papel de destaque na trajetória da automação bancária brasileira, como se verá a seguir.

Para resgatar o quadro histórico apresentado nesta seção toma-se como referência as obras de Pires (1997), Iamonti (2014), Diniz (2004), Diniz, Meirelles e Fonseca (2010) ${ }^{87}$ e de Vera Dantas (1988) e Marcos Dantas (1989), que resgatam importantes fatos da trajetória da informatização dos bancos para realizar suas análises a respeito da Política Nacional da Informática, além de dados obtidos a partir de consultas aos acervos da revista Veja, de publicações especializadas na cobertura do setor de telecomunicações e dos bancos Bradesco e Itaú.

\footnotetext{
${ }^{86} \mathrm{O}$ relatório destaca a atuação do Itaú no mercado latino-americano. Segundo o documento, o banco brasileiro teria o total de ativos de quase todo o sistema bancário mexicano - US\$ 420 bilhões. Cumpre lembrar que, justamente no ano de 2008, quando foi deflagrada a crise financeira global, o Itaú comprou o Unibanco por US\$12,5 bilhões. À época, o grupo resultante da fusão somava R \$ 575 bilhões em ativos e 14,5 milhões de clientes de conta corrente, o que correspondia a18\% do mercado.

${ }^{87}$ A obra reúne testemunhos de mais de cinquenta profissionais do mercado financeiro que estiveram, de alguma forma, envolvidos com a história da tecnologia bancária no Brasil. Os depoimentos foram colhidos em mesas-redondas, fóruns e entrevistas organizados pela Fundação Getúlio Vargas.
} 
O marco inicial da história da automação bancária data dos primeiros anos da década de 1960 (PIRES, 1997; DINIZ, 2004). À época, como explica Diniz (2004), os bancos instalados no Brasil passaram a adquirir seus primeiros computadores para automatizar as chamadas operações de retaguarda, tais como a checagem de extrato e lançamento de transações financeiras registradas manualmente pelos bancários nos registros dos correntistas da agência. Com o crescimento do volume de transações financeiras observado a partir de meados dos anos 1960, aumentava a necessidade de os bancos utilizarem as tecnologias informatizadas dos Centros de Processamento de Dados (CPDs) (PIRES, 1997).

O Bradesco foi o primeiro banco brasileiro a comprar um computador em 1962, um modelo da IBM com capacidade de 4K de memória. Nos anos seguintes, foi a vez do Banco Nacional (em 1962), Itaú (1965) e Bamerindus (1968) adquirirem máquinas e sistemas tecnológicos para informatizar suas operações (DANTAS, 1988; DINIZ; MEIRELES; FONSECA, 2010). Ainda que tais iniciativas tenham sido consideradas pioneiras no amplo quadro de automação no país,

A implantação da informática no setor bancário foi lenta, não só pelo rígido controle de despesas - ao contrário do setor governamental, extremamente perdulário na aquisição dos seus "cérebros eletrônicos"- mas também pela resistência de seus antigos funcionários (DANTAS, 1988, p. 135).

A partir da segunda metade da década de 1960, há um conjunto de fatores de ordem macroeconômica e estrutural que impulsionam, de fato, os investimentos em tecnologia bancária no país. A reforma do sistema bancário nacional, marcada pela instituição do Conselho Monetário Nacional e do Banco Central do Brasil no final de 1964, teve importante papel nessa trajetória (DINIZ, 2004). Isso porque, como resultado das mudanças institucionais no sistema financeiro, observou-se um processo de concentração bancária no país e o consequente aparecimento de grandes instituições com capacidade de dispender vultosas somas de recursos no processo de automação ${ }^{88}$ (DINIZ; MEIRELES; FONSECA, 2010). Consoante com essa afirmação, Pires (1997) argumenta que no período da "gênese da automação" no país, de 1964 a 1973, o número

\footnotetext{
${ }^{88}$ De acordo com dados apresentados em Dantas (1988), os bancos Bradesco e Itaú absorveram mais de 50 outras instituições ao longo dos anos 1970.
} 
de instituições bancárias reduziu-se pela metade (caiu de 328 para 115) e observou-se o crescimento de mais de mil e trezentas agências no Brasil (o número saltou de 6.550 para 7.931).

Em sentido inverso, Dantas (1988) propõe que a concentração do setor bancário não teria sido possível sem a tecnologia da informática, uma vez que os minicomputadores e demais máquinas utilizadas a partir desse período agilizavam o teleprocessamento contábil e o acesso a arquivos. Assim, para a autora, o crescimento da rede de agências de conglomerados bancários só foi viável com as tecnologias que garantiam às principais agências estaduais certa autonomia no fechamento contábil e capacidade de tratar e armazenar dados e emitir relatórios (DANTAS, 1988, p. 136).

Os índices de inflação observados no país nas décadas de 1960 e 1970, que chegavam a aproximadamente $40 \%$ ao ano, também desempenharam importante papel na história da automação bancária, conforme argumentam Alcir Augustinho Callari, Candido Leonelli e Eduardo Magalhães (DINIZ; MEIRELLES; FONSECA, 2010, p. 28, 37, 76) ${ }^{89}$. Além de garantir volumosos ganhos aos bancos e possibilitar os investimentos em tecnologia bancária, a inflação imprimia um segundo estímulo ao processo de informatização. Ela gerava a necessidade de adoção de equipamentos, máquinas e sistemas de processamento de dados cada vez mais velozes, que afastassem qualquer suspeita de que as instituições bancárias pudessem estar cometendo fraudes contábeis, conforme explica João Regis da Cruz Neto ${ }^{90}$ (DINIZ; MEIRELLES; FONSECA, 2010, p. 87).

Além desses dois fatores, uma terceira questão que impulsionou o processo de automação bancária é a dimensão territorial do Brasil, de proporções continentais, segundo relatam Candido Leoni, João Regis Cruz Neto e Sandra Boteguim (DINIZ;

\footnotetext{
${ }^{89}$ Funcionário de carreira do Banco do Brasil, Callari chegou à presidência da instituição no ano de 1993. Leonelli trabalhou por mais de vinte anos no Bradesco. À época da publicação de Diniz, Meirelles e Fonseca (2010) era diretor gerente do banco, responsável pelos Canais Eletrônicos, CRM, Inteligência Competitiva e Mobilidade, acumulando ainda a Presidência da Scopus. Magalhães foi vice-presidente administrativo do Unibanco. Ocupou a presidência do Conselho da Tecnologia Bancária (TecBan), empresa fundada em 1989 por várias instituições bancarias do país para disseminar a rede de autoatendimento do Banco 24 horas (DINIZ; MEIRELLES; FONSECA, 2010; IAMONTI, 2014).

${ }^{90}$ Neto ocupou cargos de diretoria nos bancos Bamerindus, Noroeste e Itaú BBA. Participou da criação do Banco24Horas (DINIZ; MEIRELLES; FONSECA, 2010, p. 87).
} 
MEIRELES; FONSECA, 2010, pg. 37, 88, 304, 305) ${ }^{91}$. De acordo com a visão desses profissionais, a expansão geográfica da rede de agências dos bancos comprometia o tempo de transporte dos dados bancários para os CPDs das instituições, que costumavam estar localizados nas capitais do país, e acarretava dificuldades no processo de compensação de cheques e outras transações bancárias. Agrava a situação o fato de o sistema de telecomunicações instalado no Brasil à época não atender às demandas específicas das instituições financeiras (p. 38). Toda essa conjuntura enfrentada pelo sistema bancário brasileiro era bastante diferente do cenário estadunidense, onde, a despeito do vasto território do país, os bancos tinham atuação regional.

Foi diante desse complexo quadro que a automação bancária ganhou, de fato, intensidade a partir da década de 1970. Num primeiro momento, como explicam Diniz, Meirelles e Fonseca (2010), as instituições bancárias brasileiras, assim como as de demais países em desenvolvimento, usavam máquinas e soluções tecnológicas desenvolvidas por grandes fornecedoras estrangeiras, como as estadunidenses Burroughs e IBM e a italiana Olivetti (DANTAS, 1988). Tais empresas, no entanto, não se interessavam em elaborar equipamentos e sistemas que atendessem especificamente a seus clientes brasileiros (DANTAS, 1988; DANTAS, 1989; DINIZ; MEIRELLES; FONSECA, 2010). O desinteresse pode ser explicado pela participação ainda pequena do Brasil no mercado mundial nos anos 1970: o país representava, no máximo, $1 \%$ dos negócios das empresas multinacionais fornecedoras de tecnologia, enquanto Estados Unidos e Europa Ocidental concentravam $62 \%$ e $25 \%$ das vendas mundiais. “Aos brasileiros não restava outra opção senão vender o que havia para ser vendido, e comprar o que existia para ser comprado" (DANTAS, 1989, p. 10).

Em meados da década, a trajetória da informatização dos bancos no país ganhou um novo e importante estímulo, quando em 1975 foi instituída a reserva de mercado de informática, conforme visto no capítulo anterior ${ }^{92}$. Com o estabelecimento de duras

\footnotetext{
${ }^{91}$ Boteguim trabalhou no Citibank, Banco Nacional, BankBoston. À época da publicação de Diniz, Meirelles e Fonseca (2010), era Diretora de Produtos do Banco Itaú (DINIZ; MEIRELLES; FONSECA, 2010).

${ }^{92} \mathrm{O}$ quadro completo de acontecimentos, resoluções e decisões políticas, estratégias empresariais e acordos de transferência de tecnologias do período da reserva de mercado de informática no Brasil é detalhadamente apresentado em Dantas (1988), Dantas (1989) e Marques (2000). Na visão dos três
} 
restrições às importações de máquinas que equipariam o setor de automação bancária, houve uma profunda reorganização do mercado brasileiro em que os bancos passam, eles mesmos, a constituir fábricas de equipamentos ou investir diretamente em empresas nacionais do setor de informática que começavam a surgir no período.

Nesse episódio particular da trajetória da automação nacional, Itaú e Bradesco são invariavelmente considerados os principais catalisadores do processo de informatização dos bancos brasileiros (DANTAS, 1988; DANTAS, 1989; DINIZ; MEIRELLES; FONSECA, 2010). O primeiro fundou, em 1979, um departamento para desenvolver máquinas e programas, o Itautec (DANTAS, 1989). Sua unidade de tecnologia logo se firmou como uma das principais empresas do setor no Brasil, atendendo outras instituições bancárias, tais como o Banco Habitasul, Citybank e Banco do Brasil (DANTAS, 1988, p. 138). Um dos primeiros projetos assumidos pelos engenheiros e técnicos da Itautec foi a construção de um terminal-caixa com tela capacitiva para ser operado pelo próprio cliente do banco (DANTAS, 1989).

A estratégia de atuação do Bradesco no mercado de automação bancária foi diferente: optou por deter participação acionária em empresas nacionais do setor de informática. Foi a partir de máquinas e sistemas projetados na SID e na Digilab que o Bradesco introduziu em suas agências as máquinas leitoras de caracteres magnéticos gravados em cheques, equipamento inédito no mercado mundial e cujo projeto não havia despertado interesse das multinacionais instaladas no país, que foram anteriormente procuradas pelo banco (DANTAS, 1988, p. 135).

Nesse período, ganhou destaque também a atuação da estatal Cobra (Computadores e Sistemas Brasileiros), criada ainda no ano de 1974. Como sintetiza Marcos Dantas (1989), em julho de 1977, o capital da empresa foi dividido entre uma associação de instituições governamentais (entre eles o Banco Nacional de Desenvolvimento Econômico e Social, a Caixa Econômica Federal e o Banco do Brasil) e um consórcio de bancos privados formado por Bradesco, Itaú, Nacional e outras instituições ${ }^{93}$. Em 1980, a empresa foi responsável por produzir o Cobra 530, primeiro

autores, a política de restrição às importações e os incentivos à indústria nacional de informática teve sucesso como instrumento de desenvolvimento industrial e tecnológico do país.

${ }^{93}$ A Cobra era, conforme explica Dantas (1988), um dos dois empreendimentos da Digibrás, empresa criada pela Capre em 1973, com o nome de Eletrônica Digital Brasileira, para instituir uma fábrica nacional de computadores (DANTAS, 1988, p. 49). Ao longo dos anos, o controle acionário da Cobra 
minicomputador brasileiro que inseriu o Brasil no "estado-de-arte da informática mundial" (DANTAS, 1989, p. 39).

Essa indústria nacional de computação que se desenvolveu a partir da segunda metade da década de 1970 foi destaque em reportagem publicada pela revista Veja em 1982 com o título "Os barões eletrônicos". Segundo dados apresentados na reportagem, as vendas das empresas filiadas à Associação Brasileira da Indústria de Computadores e Periféricos (Abicomp) atingiram, em 1981, R\$ 2,5 bilhões ${ }^{94}$, o que representou um crescimento de $30 \%$ acima da inflação sobre o faturamento no ano anterior. Enquanto isso, o setor industrial brasileiro havia registrado uma queda de $10 \%$ em suas atividades em relação ao ano de 1980 (BARBOSA, 1982, p. 50).

A publicação narrava em detalhes como foram criadas algumas das grandes empresas nacionais de informática após a instituição da reserva de mercado, tais como a Scopus, (1975), Prológica (1976), Digirede (1976), Embracomp (1977) e SID (1978) (BARBOSA, 1982; IAMONTI, 2014). Aos leitores, era apresentado em um infográfico a lista das dez maiores empresas brasileiras do setor ${ }^{95}$ :

Tabela 7 - As dez maiores empresas nacionais de informática em 1982

\begin{tabular}{lcc}
\hline Empresa & Faturamento em R\$ & Número de empregados \\
\hline Cobra & $693.885 .572,68$ & 2.000 \\
Edisa & $192.057 .613,87$ & 350 \\
Labo & $192.057 .613,87$ & 570 \\
Sid & $185.862 .206,97$ & 480 \\
Sisco & $130.103 .544,88$ & 387 \\
Elebra & $123.908 .137,98$ & 360 \\
Scopus & $105.321 .917,28$ & 410 \\
Giobus & $86.735 .696,59$ & 160 \\
\hline
\end{tabular}

passou por diversas mudanças. No final da década de setenta, 39\% do capital da empresa chegou a ser controlado por um consórcio formado por treze instituições financeiras: Bradesco, Itaú, Nacional, Econômico, Auxiliar de São Paulo, Banco da Bahia, Bamerindus, Banco de Crédito Nacional, Caixa Econômica do Estado de São Paulo, Banco do Estado de São Paulo, Banco Noroeste do Estado de São Paulo e as Bolsas de Valores do Rio e de São Paulo (DANTAS, 1988, p. 67-68). Ao longo dos anos oitenta, os bancos privados retiraram-se do controle da Cobra (DANTAS, 1989). Na década de 1990, o Banco do Brasil adquiriu a maior parte das ações da empresa, que passou a se chamar, em 2013, BB Tecnologias e Serviços. Um breve histórico da Cobra está disponível em:

< http://www.cobra.com.br/index.php/a-empresa/nossa-historia >. Acesso em: 27 out. 2016.

${ }_{94} \mathrm{O}$ valor informado na publicação, $\mathrm{Cr} \$ 41$ bilhões, foi corrigido pelo índice IPC-A (IBGE) a partir da ferramenta Calculadora do cidadão do Banco Central disponível em:

<https://www3.bcb.gov.br/CALCIDADAO/publico/corrigirPorIndice.do?method=corrigirPorIndice\#>. ${ }^{95}$ Os valores originalmente apresentados em cruzeiros $(\mathrm{Cr} \$)$ na tabela também foram corrigidos pelo índice IPC-A (IBGE) a partir da ferramenta Calculadora do cidadão do Banco Central. 


\begin{tabular}{lll}
\hline Polimax & $83.637 .993,14$ & 280 \\
Prológica & $61.954 .068,99$ & 200 \\
\hline
\end{tabular}

Fonte: Barbosa (1982), com dados fornecidos pelas empresas

Analisando o quadro de inovações da automação bancária, desenvolvidas nas décadas de setenta e oitenta, apresentado em Diniz (2004), registra-se, no primeiro período, a instalação dos primeiros subcentros regionais dos bancos equipados com minicomputadores e experiências pioneiras com cartão magnético (DANTAS, 1988; DINIZ, 2004; DINIZ; MEIRELLES; FONSECA, 2010, p. 61-63). Nos anos de 1980, conforme argumenta o autor, a informatização dos bancos do Brasil voltou-se de vez para as atividades de atendimento aos clientes e processamento online. Nessa fase, observou-se no mercado nacional o desenvolvimento do conceito de "banco eletrônico" e o surgimento de tecnologias correlatas a essa ideia, como os caixas eletrônicos ${ }^{96}$ e os primeiros canais de atendimento telefônico. Como explica o autor,

A automação crescente das agências, acompanhada por uma maior integração aos sistemas centrais dos bancos, contribuiu para que o usuário do sistema bancário deixasse de ser apenas cliente de uma agência específica para tornar-se cliente do banco como um todo [...]. Acreditava-se que, quanto mais automatizado fosse um banco, mais clientes ele conseguiria. Assim, a agilidade propiciada pela automação passou a ser valorizada como diferencial competitivo. Surgiram então slogans tais como "banco eletrônico" (Itaú), "banco dia e noite" (Bradesco) e "banco 24 horas" (Unibanco) (DINIZ, 2004, p. 57-58).

Na edição de 22 de dezembro de 1982, a revista Veja anunciava, com bastante entusiasmo, as invenções que haviam sido lançadas há pouco no mercado brasileiro de automação bancária, como o "Serviço de Resposta Audível” do Itaú, e outras novidades que chegariam nos próximos meses no país, como os caixas automáticos (Automatic Teller Machine ou simplesmente ATM, em inglês). A reportagem "Cibernética bancária" destacava ainda o surgimento das agências online, inauguradas pelo Itaú e

\footnotetext{
${ }^{96}$ O primeiro ATM do mundo foi instalado em uma agência do banco Barclays em Londres em 1967. No Brasil, o primeiro caixa eletrônico teria sido instalado em abril de 1983 em uma agência do banco Itaú em Campinas (SACONI, 2013). Há, no entanto, relatos que dão conta que a tecnologia já havia sido introduzida no mercado brasileiro nos anos de 1981 e 1982 (PIMENTEL, 2007; MORAES, 2008).
} 
Bradesco em 1981 (DINIZ, 1988), como um recurso para promover economia de tempo e recursos paras as instituições financeiras ${ }^{97}$ :

\begin{abstract}
Nas agências convencionais, o fechamento e a atualização do movimento configuram uma luta árdua e demorada. Primeiro, todas as operações são registradas em formulários. Depois, a papelada segue, geralmente em caminhões, rumo a uma central de processamento de dados onde um computador recebe e digere as informações. Finalmente, o computador imprime uma listagem atualizada para cada agência. Esse trabalho só termina na madrugada e outra vez, agora no sentido inverso, caminhões blindados transportam a papelada. Nas agências eletrônicas, esse esforço já pertence à pré-história dos bancos. Cada operação é transmitida instantaneamente, no momento em que ocorre, ao computador central. Desse modo, elimina-se uma montanha de papeis e ganhamse várias horas (NOGUEIRA, 1982).
\end{abstract}

Iamonti (2014) lembra que esse processo de integração eletrônica da rede de agências aos escritórios centrais dos bancos foi catalisado com o lançamento da rede Transdata, serviço de transmissão de dados criado oficialmente em 1980, conforme visto no capítulo anterior. Nos anos seguintes, a Embratel passou a oferecer também serviços de comunicação com o exterior (BENAKOUCHE, 1997) ${ }^{98}$. Em 1982, houve a extensão para o Brasil da rede ligada à Sociedade de Telecomunicações Financeiras Interbancárias Mundiais (Society for Worldwide Interbank Financial Telecommunications - SWIFT, em inglês) (DIAS, 1996), um canal de comunicação global que permite a troca de mensagens financeiras, como a transferência eletrônica de fundos entre as instituições participantes ${ }^{99}$.

A inauguração da internet comercial, em 1995, marca também o desenvolvimento de aplicações utilizando a rede mundial de computadores no cenário da automação bancária. No Brasil, o Bradesco, desempenhou papel protagonista em ao

\footnotetext{
${ }^{97}$ Diniz (2004) aponta que, a partir do Plano Cruzado, em 1986, e o conjunto de esforços para a estabilização da economia, a automação bancária também passou a ser vista como um instrumento de redução de custos dos bancos brasileiros.

${ }^{98}$ Carvalho (2006) explica que o acesso a partir do Brasil à rede de comunicação de dados do exterior foi facilitado com a criação da SEI (no ano de 1979), em substituição à Capre, que adotava medidas mais restritivas para o intercâmbio de dados com o exterior (CARVALHO, 2006, p. 60-61).

${ }^{99}$ Criada em 1973 por 239 bancos de 15 países, a SWIFT estabeleceu, no ano de 1977, uma rede de telecomunicação mundial de transações financeiras em substituição ao telex, usado até então para comunicação entre os bancos. Em 2009, integrando 209 países, a rede registrou a troca de 3,76 bilhões de mensagens por ano, conforme informa o site da instituição <https://www.swift.com/aboutus/history>. Acesso em: 28 out. 2016.
} 
menos três empreendimentos: lançou o primeiro site comercial do Brasil, o Bradesco Net em 1995; foi a primeira instituição bancária do Brasil e a quinta do mundo a oferecer serviço de internet banking a seus correntistas, em 1996; e anunciou, ainda em 1999, que ofereceria serviço de acesso gratuito à internet, impulsionando o movimento de internet grátis no país, como se verá em mais detalhes a seguir (PANTOJA; FERREIRA, 2000; DINIZ; MEIRELLES; FONSECA, 2010).

Antes, porém, de passarem a oferecer seus serviços na rede mundial de computadores, os bancos, em geral, já vinham desenvolvendo tecnologias para que seus clientes acessassem suas informações bancárias remotamente. Como explica Diniz (2004),

A popularização dos computadores pessoais ao longo dos anos noventa levou ao surgimento dos conceitos de home banking e office banking. À época do lançamento do home banking, acreditava-se que ele seria tão bem aceito quanto os terminais de atendimento. Nessa primeira fase, o sistema era apoiado por softwares proprietários fornecidos pelos bancos por meio de disquetes e a conexão era feita por linha discada (DINIZ, 2004, p. 58).

Entre as ferramentas necessárias para dispor dos serviços oferecidos pelo home banking figuravam os telefones, faxes, televisores e computadores. Uma novidade que chegou a ser oferecida aos correntistas do Bradesco foi a conexão com o banco a partir de videogames e da televisão. Para isso, era necessário inserir um cartucho especial e conectar o aparelho à televisão (MENCONI; NETO, 1995).

Cumpre pontuar que, nessa mesma década, com a edição da Lei $\mathrm{n}^{0} 8.248$, em 1992, e o fim da reserva de mercado de informática que vigorava no país desde 1975, houve uma nova reorganização na indústria de automação bancária nacional (IAMONTI, 2014). As empresas constituídas ao longo dos dezessete anos em que vigoravam restrições às importações de computadores no país passaram a firmar parcerias estratégicas com grandes multinacionais para se reposicionarem no mercado. No caso do Bradesco, particularmente, houve um acordo com a Sharp, empresa japonesa que, no Brasil, era administrada sob contrato de licenciamento por um empresário gaúcho. O banco adquiriu $19 \%$ das ações da Sharp brasileira e, em 
contrapartida, cedeu à empresa o controle da Digilab (CAIXA..., 1992; FERREIRA, 2015).

No quadro macroeconômico, com o lançamento do Plano Real em 1994 e a consequente redução dos ganhos inflacionários dos bancos (já afetados com o lançamento do Plano Cruzado em 1986), as instituições ampliaram seus investimentos em tecnologias que representassem redução de custos, enxugamento do número de agências e funcionários ${ }^{100}$ (MENCONI; NETO, 1995). As transações digitais eram um importante recurso de que as instituições bancárias dispunham para reduzir seus gastos. Isso porque um depósito ou compensação de cheque realizado em uma agência acarretava, em 1995, um custo de $R$ \$ 2, enquanto a mesma transação custava $R$ \$ 0,20 se fosse realizada em um terminal eletrônico. Desta forma, o investimento em automação bancária movimentava cifras bilionárias: apenas no ano de 1994, a venda de aparelhos de informática para bancos no Brasil movimentou US\$ 4,1 bilhão.

Ainda na década de 1990, no plano institucional, para socorrer as dezenas de bancos privadas e estatais que enfrentavam dificuldades financeiras, o governo de Fernando Henrique Cardoso editou, em 1995 e 1996, o Programa de Estímulo à Reestruturação e ao Fortalecimento do Sistema Financeiro Nacional (Proer) e o Programa de Incentivo à Redução do Setor Público Estadual na Atividade Bancária (Proes) (IAMONTI, 2014). O primeiro consistia numa intervenção do Banco Central que, após injetar recursos nas instituições bancárias em bancarrota, promovia a fusão e incorporação a outra instituição financeira considerada saudável. O programa custou cerca $\mathrm{R} \$ 15$ bilhões à época, o que corresponde a $\mathrm{R} \$ 37,8$ bilhões em valores corrigidos $^{101}$ (GRADILONE, 2013). Tal ação teria incentivado, conforme argumenta Iamonti (2014), a entrada de grandes bancos estrangeiros no país.

\footnotetext{
${ }^{100}$ De acordo com dados apresentados em Pires (1997), apenas no ano de 1990, 77.273 postos de trabalho do setor bancário foram fechados, o que correspondia a 8,5\% do emprego do setor financeiro privado. Entre os anos de 1990 e 1995, a automação teria contribuído para a demissão de 120 mil bancários (MENCONI; NETO, 1995). Ainda que tais demissões sejam resultado de mudanças organizacionais amplas, não se deve ignorar que a informatização dos sistemas bancários possibilitou que as instituições bancárias reduzissem o número de seus funcionários.

${ }^{101} \mathrm{O}$ valor foi atualizado pelo índice IPCA-E a partir da ferramenta Calculadora do cidadão do Banco Central disponível em:

<https://www3.bcb.gov.br/CALCIDADAO/publico/corrigirPorIndice.do?method=corrigirPorIndice\#〉. Acesso em: 28 out. 2016.
} 
O segundo programa, o Proes, foi destinado aos bancos controlados por governos estaduais que, além de sofrerem os reveses da estabilidade econômica do país, apresentavam prejuízos volumosos decorrentes da má administração financeira dos governos estaduais, que os utilizavam como caixas informais ${ }^{102}$. Segundo reportagem do jornal Folha de S. Paulo publicada em 2002, o custo desse programa chegou, naquele ano, a R $\$ 90$ bilhões, o que corresponde a $\mathrm{R} \$ 227,2$ bilhões em valores atualizados ${ }^{103}$. A mesma reportagem informava que investigações conduzidas pelo Banco Central à época davam conta que parte considerável dos empréstimos concedidos pelos bancos estaduais antes de entrarem em processo de falência serviu para financiar rombos dos Estados e beneficiar políticos e empresários que não tinham condições de arcar com os compromissos financeiros assumidos (FRIEDLANDER; GRINBAUM, 2000).

Com essas duas medidas de salvaguardas do Governo Federal ${ }^{104}$, o sistema financeiro nacional não só sobreviveu à virada do milênio sem nenhuma hecatombe relevante como recebeu estímulos importantes ao já antigo processo de concentração bancária $^{105}$.

No quadro da automação, já a partir dos anos 2000, além de os bancos lançarem provedores de internet, como será visto a seguir, observa-se, no quadro da automação

${ }^{102}$ Em janeiro de 2017, em meio à grave crise financeira que assola diversos estados do Brasil, o Banrisul, banco estadual do Rio Grande do Sul, foi colocado na mesa de negociação do socorro financeiro que o Governo Federal oferecerá ao Estado gaúcho. Conforme foi noticiado, o ministro da Fazenda, Henrique Meirelles (dono de um banco digital, como se verá a seguir), estabeleceu que a federalização ou privatização do Banrisul poderá ampliar as vantagens oferecidas na ajuda federal ao Estado (MAZUI; BULBLITZ; CALDAS, 2017).

${ }^{103}$ Esse valor também foi atualizado pelo índice IPCA-E disposto na Calculadora do cidadão em: <https://www3.bcb.gov.br/CALCIDADAO/publico/corrigirPorIndice.do?method=corrigirPorIndice\#>. Acesso em: 28 out. 2016.

${ }^{104}$ Em 2001, o governo lançou ainda um terceiro pacote de apoio aos bancos públicos federais, o Programa de Fortalecimento das Instituições Financeiras Federais. O Proef destinou, até novembro de 2013, R \$ 29 bilhões (R\$ 36,6 bilhões em valores corrigidos) ao Banco do Brasil, Caixa Econômica Federal e, em menor escala, BNDES, Banco da Amazônia e o Meridional (GRADILONE, 2013).

${ }^{105}$ Desde a perspectiva da Geografia, Pires (1997) sistematiza as quatro primeiras décadas da automação bancária brasileira em três fases distintas, considerando, entre outros critérios, as características de gestão dos bancos, o nível de territorialização dos serviços e os modelos de gestão de trabalho. A fase da "Gênese da Automação Bancária", que vai de 1964 a1973, é caracterizada por uma gestão financeira taylorista, baixo nível de dispersão territorial dos bancos e gestão centrada-concentrada das atividades bancárias. A segunda fase, observada entre os anos de 1974 a 1986, é a da "Dispersão Territorial Oligopolizada e Confinada da Automação Bancária", marcada pela gestão fordista, alcance de médio a alto das atividades dos bancos nos território brasileiro e gestão bancária descentralizada-desconcentrada. Por fim, a terceira fase, da "Reestruturação Inovativa e Desregulamentativa da Automação Bancária", dos anos de 1987 a 1997, é caracterizada por uma gestão financeira flexível, alta dispersão territorial das atividades dos bancos e um modelo de gestão das atividades bancárias descentralizada-instantânea (PIRES, 1997, p. 3). 
bancária, o avanço do internet banking como canal de atendimento de correntistas. De acordo com dados apresentados por Diniz (2004), entre 2001 e 2002, o volume de transações avançou 178\%, registrando 2,2 bilhões de operações. Ainda segundo o autor, em 2000, havia 8,3 milhões de usuários de internet banking. Em 2001, o número saltou para 13 milhões e, no ano seguinte, atingiu 14,9 milhões.

No cenário estadunidense, não foi diferente o crescimento do uso dos canais digitais de atendimento dos bancos. De acordo com dados do instituto Pew Reserach Center, em 2000, 16 milhões de pessoas usavam ferramentas de internet banking, o que representava $17 \%$ da população daquele país; em 2002, o número saltou para 37 milhões - 32\% da população - e, em 2005, já havia 53 milhões de correntistas usando a internet para realizar transações bancárias (PEW RESEARCH CENTER, 2002, 2005, 2006). O gráfico 7, representa o crescimento do internet banking de 1998 a 2005 no cenário estadunidense.

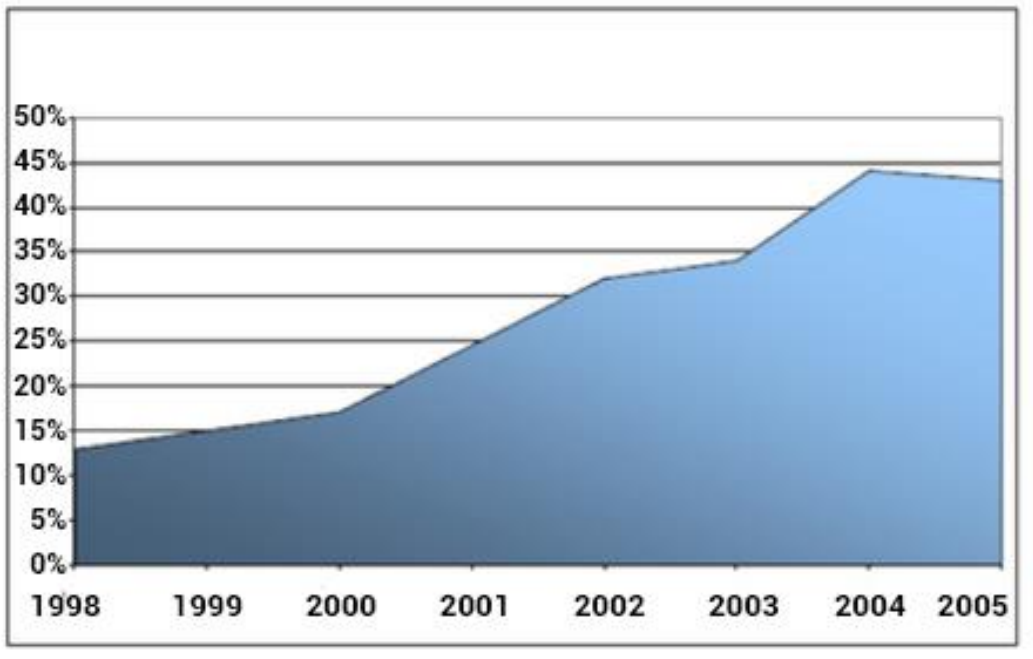

Gráfico 7 - Percentual de internautas que usam internet banking nos Estados Unidos Fonte: Pew Research Center

Ainda que o crescimento tenha sido considerável nos Estados Unidos no começo dessa década, a Febraban estimava que, no ano 2000, era maior o número de bancos no Brasil que ofereciam serviços na internet. Segundo a Federação (PANTOJA; FERREIRA, 2000), o número total de instituições bancárias nos Estados Unidos era 43 
vezes maior e a taxa de adesão ao internet banking era de 11,3\%. No Brasil, 50\% dos bancos já ofereciam serviços na internet no ano 2000. Entre os líderes de clientes online, estavam Bradesco (com 770 mil correntistas usuários de internet banking), Banco do Brasil (711 mil), Itaú (400 mil) e Unibanco (100 mil).

Alguns bancos brasileiros também passaram a oferecer de maneira pioneira no país, ainda no ano de 2000, o acesso a serviços de internet banking por aparelhos celulares dotados da tecnologia Wireless Aplication Protocol (WAP), em português, Protocolo de Aplicação Sem Fio. Os correntistas que tinham celulares WAP conseguiam, por exemplo, consultar saldo e extrato em seus aparelhos. O Itaú permitia transferências entre contas do mesmo banco e o Bradesco possibilitava até o pagamento de contas (FERNANDES; PADUAN, 2000).

Considerando o quadro que se apresenta a partir dos anos 2010, é possível destacar algumas das tendências que já despontam no horizonte de inovações do setor de tecnologia bancária nesta década. Em primeiro lugar, como apresenta a Pesquisa Febraban de Tecnologia Bancária 2015 ${ }^{106}$, as transações via celular, o mobile banking, vem se consolidando como um importante canal digital de atendimento. Segundo a pesquisa, em 2015, havia 33 milhões de contas bancárias com acesso a recursos do mobile banking, o que representou um crescimento de $32 \%$ em relação ao ano de 2014 , quando havia 25 milhões de contas acessíveis por meio de aparelhos celulares. Foram registrados 11,2 bilhões de transações bancárias via smartphone: uma alta de 138\% em relação ao total de 2014 - 4,7 bilhões de transações. Para se ter uma ideia do crescimento acumulado do mobile banking nesta década, em 2011, foram registradas apenas 100 milhões de operações por meio dos celulares ${ }^{107}$.

Como se nota no gráfico 8 , em 2015, 21\% das operações foram realizadas via mobile banking e $33 \%$ por internet banking. Juntos, esses dois canais digitais responderam por 28,9 bilhões de transações - $54 \%$ do total de transações e atendimentos bancários (com e sem movimentação financeira).

\footnotetext{
${ }^{106}$ Realizada pela Federação Brasileira de Bancos (Febraban) em parceria com a Deloitte, a Pesquisa de Tecnologia Bancária de 2015 avaliou dados de 17 bancos do país, que representam 93\% dos ativos do setor bancário brasileiro (FEDERAÇÃO BRASILEIRA DOS BANCOS, 2015).

${ }^{107}$ A mesma pesquisa indicou que, de 2014 para 2015, houve recuo no número de agências (de 23.100 para 22.900), Postos de Atendimento Bancário e Postos de Atendimento Eletrônico - PABs e PAEs (de 51 mil para 45.500) e de Correspondentes Bancários (de 346.500 para 293.800) (Ibid., 2015, p. 27).
} 


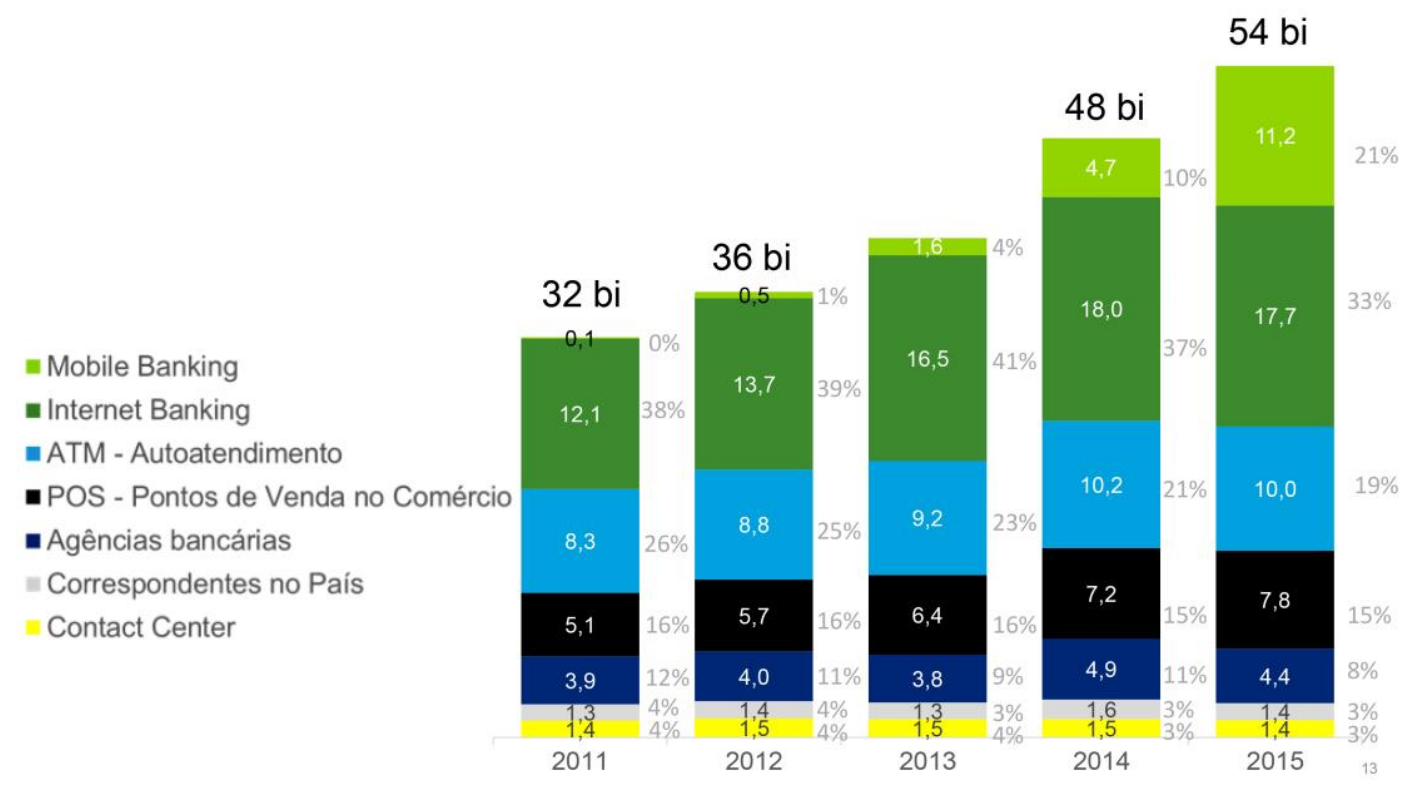

Gráfico 8 - Transações e atendimentos por canais de atendimento dos bancos Fonte: Pesquisa FEBRABAN 2015

Outro dado relevante apresentado pela Pesquisa de Tecnologia Bancária de 2015 é o total de investimentos e despesas do setor bancário brasileiro em tecnologia. Naquele ano, os bancos nacionais dispenderam R \$ 19 bilhões em telecomunicação, hardware e software - R \$ 5 bilhões em investimentos e R $\$ 14$ bilhões em despesas ${ }^{108}$. Tomando apenas os investimentos em tecnologia em separado, houve um recuo em comparação ao que foi gasto no ano anterior: em 2014, registraram-se gastos no valor de R \$ 8 bilhões ${ }^{109}$. No cenário global, também recuaram os dispêndios com tecnologia bancária neste período: de US\$ 362 bilhões de dólares para US\$ 351 bilhões em 2015.

\footnotetext{
${ }^{108}$ Segundo informações fornecidas pelo vice-presidente do Bradesco, Maurício Machado de Minas, à revista Época Negócios, só esse banco dispenderia anualmente $\mathrm{R} \$ 6$ bilhões em custeio e investimento do setor de tecnologia e infraestrutura (BRADESCO..., 2016).

${ }^{109}$ Embora os investimentos tenham diminuído, o Brasil ocupa o sétimo lugar no ranking de gastos com tecnologia da informação no setor bancário, atrás de Reino Unido, Estados Unidos, Canadá, Japão, França e Alemanha (FEDERAÇÃO BRASILEIRA DE BANCOS, 2015, p. 38).
} 
Além da consolidação do mobile banking, outras grandes tendências podem ser mapeadas no mercado nos últimos anos. Uma delas é o uso crescente de ferramentas de Big Data para auxiliar a criação de grandes bancos de dados a serem utilizados para oferta de produtos aos correntistas e detecção de fraudes em sistemas bancários. Também tem se registrado nas instituições a preocupação com a virtualização de dados e processadores, por meio de tecnologias de Cloud Computing, para promover melhor gestão de recursos computacionais. Outra tendência em curso é a automação de processos que ainda são feitos de maneira manual, buscando-se com isso a redução de custos, erros e tempo de processamento das operações, o aumento da segurança e a melhoria da experiência do cliente (FEDERAÇÃO BRASILEIRA DE BANCOS, 2012).

Ainda ganham destaque nesta década o surgimento de bancos digitais ${ }^{110} \mathrm{e}$ das chamadas fintechs, termo dado a startups do mercado financeiro surgidas nos últimos anos (PERRIN, 2016) ${ }^{111}$. É o caso do Banco Original, um "banco 100\% digital”, como diz o slogan da instituição que entrou em operação em março de 2016. Idealizado pelo ex-presidente do Banco Central (2003-2011) ${ }^{112}$ e atual ministro da Fazenda, Henrique Meirelles. Lançado em março de 2016, o banco oferece todos seus serviços bancários em plataformas digitais. Se necessário, os saques de valores em espécie podem ser

\footnotetext{
${ }^{110}$ Em abril de 2016, o Conselho Monetário Nacional permitiu a abertura de contas correntes e cadernetas de poupança pela internet. Antes disso, era preciso se dirigir a uma agência bancária com toda documentação exigida pela instituição para que o serviço bancário fosse prestado (VALENTE, 2016).

${ }^{111}$ A atuação dos bancos digitais e fintechs não se confunde com a complexa rede de pagamento do Bitcoin, criado em 2009. Trata-se de uma moeda completamente virtual regulada a partir de seus usuários, sem a intervenção de uma autoridade central. Segundo informa a página institucional do Bitcoin, a moeda é resultado da implementação do conceito de "cryptocurrency", descrito ainda em 1998 em lista de e-mails cyberpunk, que sugeria a criação de uma forma de dinheiro que utilizasse a criptografia em suas transações. De maneira simplificada, o Bitcoin pode ser descrito como uma espécie de "bem digital" transferível de um internauta a outro, sem intermediação de um banco. A movimentação de valores entre usuários da rede do Bitcoin é auditada por "mineradores", usuários detentores de softwares capazes de garantir que o valor digital dispendido por uma parte seja recebido e registrado na carteira digital pela outra parte. Esse complexo sistema de verificação de transações tem chamado a atenção de algumas instituições financeiras interessadas em utilizar uma das tecnologias por trás do Bitcoin, o blockchain (cadeia de bloco, em português), no desenvolvimento de aplicações e serviços digitais. É o caso do Itaú e do Bradesco que integram um consórcio internacional composto por mais de 50 bancos de todo o mundo dedicado a elaborar padrões e normas para utilização do blockchain no mercado financeiro global - o R3. Conforme foi noticiado pelo jornal Valor Econômico, o Bradesco pretendia iniciar, em breve, testes com a tecnologia blockchain na cidade de São Paulo (BRADESCO..., 2016; BRIGATTO, 2016).
}

112 A galeria de ex-presidentes do Banco Central pode ser visualizada em <https://www.bcb.gov.br/pre/GaleriadosPresidentes/default-p.asp>. Acesso em: 10 out. 2016. 
feitos em caixas eletrônicos da rede 24 horas. Para que tal instituição financeira começasse a operar neste ano, o grupo $\mathrm{J}_{\mathrm{N}} \mathrm{F}^{113}$, controlador do Banco Original, investiu R\$ 600 milhões nos últimos três anos (GOULART, 2016).

Outros exemplos de instituições financeiras digitais são o Nubank, lançado ainda em 2014, e o Neon, de julho de 2016, que oferecem cartões de crédito para clientes da população de renda mais baixa. Ambos não cobram taxas de anuidade, têm tarifas mais baratas que as oferecidas pelo mercado e oferecem a seus correntistas a possibilidade de gerenciar limites, gastos e visualizar extratos por meio de seus aplicativos de celular.

Procurando acompanhar a tendência digital, algumas instituições bancárias brasileiras já bastante consolidadas no mercado, tais como Santander, Banco do Brasil e Bradesco vêm estudando como simplificar seus produtos e serviços a partir de ferramentas e funcionalidades do ambiente virtual (PAIVA, 2016a, 2016b, 2016c; BANCO..., 2016).

No setor de pagamentos, cabe destacar como tendência as tecnologias Near Field Communication (NFC), que permitem a quitação de valores ou saque de dinheiro em caixas eletrônicos por aproximação de smartphones, em substituição ao uso de cartões magnéticos. O Banco do Brasil e o Bradesco já vem oferecendo alguns serviços a seus correntistas por meio desta tecnologia (BRADESCO..., 2016; PAIVA, 2016a). A integração da Internet das Coisas com a indústria de pagamentos, permitindo a transferência de recursos a partir de dispositivos instalados em carros, geladeiras e outros objetos, também se apresenta como um cenário a ser confirmado nos próximos anos (PAIVA, 2016c).

É possível destacar ainda como tendência para a automação bancária nos próximos anos o uso da computação cognitiva, especialmente no setor de relacionamento com os clientes. O Banco do Brasil, por exemplo, conduziu testes para utilizar, em breve, o assistente de voz do Watson, supercomputador cognitivo da empresa estadunidense IBM, que poderá interpretar comandos sonoros dos portadores

\footnotetext{
${ }^{113}$ A J\&F Investimentos, criada em 1953, é, de acordo com seu próprio material institucional, o maior grupo econômico privado do Brasil. Entre as empresas que constam em seu portfólio estão a JBS (empresa do setor de processamento de proteína animal), a Vigor (do setor de processamento de leite) e a Alpagartas (empresa de calçados e vestuários). Mais informações a respeito da J\&F Investimentos estão disponíveis em <http://jfinvest.com.br/quem-somos/apresentacao/>. Acesso em: 16 nov. 2016.
} 
de smartphones e realizar até 144 transações (BANCO..., 2016). Como relatou o vicepresidente de Tecnologia do Banco do Brasil, Geraldo Dezena, em entrevista à Agência Brasil, futuramente, o uso da computação cognitiva poderá desobrigar os funcionários a ensinar os clientes a usar terminais de autoatendimento, aplicativos ou computadores, uma vez que "mesmo a pessoa mais simples vai poder conversar com a máquina" (MÁXIMO, 2016).

Por fim, cabe apontar no amplo quadro de tendências que se apresentam nos anos de 2010, os serviços de dinheiro móvel, lançadas recentemente no mercado nacional e internacional. No Brasil, a Caixa Econômica Federal em parceria com a TIM lançou, em março de 2015, o TIM Multibank da Caixa. Trata-se de uma contra prépaga da Caixa que pode ser acessada por meio de aparelho celular da operadora TIM. Por meio de envio de mensagens SMS, os usuários do dinheiro móvel conseguem enviar dinheiro para outras contas TIM Multibank Caixa, realizar pagamentos e verificar saldo e extratos. É possível ainda realizar saques em casas lotéricas e correspondentes bancários da Caixa. A operadora Vivo oferece vantagens semelhantes em seu próprio serviço de dinheiro móvel, o Vivo Zuum (STRIPOLI, 2013).

Segundo um levantamento da GSMA ${ }^{114}$ divulgado em maio de 2015, havia 14,9 milhões de contas de serviço de dinheiro móvel registradas em 37 serviços disponíveis na América Latina naquele ano (PAIVA, 2015a). Em outro relatório publicado em fevereiro de 2016, a entidade apontou que, em 2015, foram abertas 100 milhões de novas contas desta modalidade, o que elevou para 411 milhões o número total de usuários de dinheiro móvel naquele ano. No total, havia 271 prestadores desse serviço financeiro em 93 países do globo. Em termos de transações realizadas, apenas em dezembro de 2015, registrou-se mais de um bilhão de operações processadas.

Considerando o que foi exposto nesta seção, a trajetória da automação bancária no Brasil pode ser apresentada, em síntese, da seguinte forma:

\footnotetext{
${ }^{114}$ A GSMA é uma entidade internacional que representa os pleitos e interesses da indústria mundial de comunicação móvel. Há cerca de 800 operadoras de telecomunicações e 200 fabricantes de aparelhos celulares, companhias de softwares, internet e mídia e entretenimento associados a GSMA. Um breve histórico da entidade está disponível em <http://www.gsma.com/aboutus/history>. Acesso em: 16 nov. 2016.
} 
Tabela 8 - Fases da automação bancária no Brasil

\begin{tabular}{|c|c|}
\hline Período & Principais fatos e inovações em tecnologia bancária \\
\hline Anos 1960 & $\begin{array}{l}\text { Início da concentração bancária } \\
\text { Disseminação de agências } \\
\text { Primeiros computadores instalados em bancos }\end{array}$ \\
\hline Anos 1970 & $\begin{array}{l}\text { Primeiros subcentros com minicomputadores } \\
\text { Primeiras experiências com cartão magnético } \\
\text { Surgimento de empresas nacionais do setor de informática }\end{array}$ \\
\hline Anos 1980 & $\begin{array}{l}\text { Primeiras agências eletrônicas com tecnologia nacional } \\
\text { Grandes bancos iniciam marketing do banco digital } \\
\text { Primeiros caixas eletrônicos fora da agência } \\
\text { Primeiros serviços de banco por telefone }\end{array}$ \\
\hline Anos 1990 & $\begin{array}{l}\text { Consolidação dos serviços home banking } \\
\text { Primeiro internet banking é lançado no Brasil pelo Bradesco }\end{array}$ \\
\hline Anos 2000 & $\begin{array}{l}\text { Consolidação do internet banking } \\
\text { Bancos lançam provedores de internet grátis }\end{array}$ \\
\hline Anos 2010 & $\begin{array}{l}\text { Expansão do mobile banking } \\
\text { Bancos digitais e fintechs } \\
\text { Tendências: Big Data; pagamento por NFC; blockchain; computação } \\
\text { cognitiva; dinheiro móvel }\end{array}$ \\
\hline
\end{tabular}

Fonte: Diniz (2004); adaptada pela autora

\subsection{Os bancos e a internet: os casos Bradesco de 1999 e 2014}

Como foi apresentado no capítulo anterior, em 1995, houve uma ruptura fundamental na organização da internet de uma lógica estatal-militar-acadêmica para outra acadêmica-mercantil (BOLAÑO; VIEIRA, 2014). No cenário internacional, há uma virada fundamental na organização do sistema, nos termos de Phan e N'Guyen (1999), quando AOL, o Teletel francês e outros possíveis concorrentes da rede mundial de computadores passam a oferecer passarelas de acesso a essa rede. É naquele ano também que a NSFNET encerra suas atividades. No Brasil, a publicação da Norma 4/1995 permitiu que agentes privados, e não só a Embratel, disponibilizassem acesso à internet no país. Nesse mesmo ano, o banco Bradesco lançou o primeiro site comercial brasileiro, o que pode ser considerado, para fins desta dissertação, um importante ponto de intersecção entre o desenvolvimento da internet e a trajetória da automação bancária no Brasil. 
Conforme sintetizam Diniz, Meirelles e Fonseca (2010), até o começo da década de noventa, as instituições bancárias vinham oferecendo serviços remotos a seus correntistas, o chamado home banking ${ }^{115}$, por meio de três estratégias distintas: i) softwares proprietários oferecidos pelos próprios bancos; ii) softwares de administração financeira que se conectavam aos sistemas dos bancos por meio de linhas telefônicas; e iii) serviços bancários "online" apoiados em plataformas "genéricas", como a AOL nos Estados Unidos e o videotexto, no Brasil e na França. Com a abertura comercial da internet em 1995, esses serviços de home banking, que até então não apresentavam grande adesão, passaram a ser oferecidos pelos bancos, num curto intervalo de tempo, através da rede mundial de computadores ${ }^{116}$.

O primeiro passo neste sentido foi dado pelo Bradesco que lançou, naquele mesmo ano seu site, o BradescoNet - num primeiro momento, uma página eletrônica estática meramente informativa, que apresentava aos internautas um conteúdo institucional do banco, como explica o executivo que liderou a criação do endereço eletrônico, Odécio Gregio, em Diniz, Meirelles e Fonseca (2010):

\begin{abstract}
Montamos o primeiro site sem saber realmente como as coisas funcionavam. O banco estava fazendo 50 anos e tinha acabado de sair um guia em português e inglês sobre a história do Bradesco. Com esse material, desenhei umas páginas, pegamos fotos e textos da história do Banco e criamos o primeiro "site" oficial, que não tinha nada de prestação de serviços. O lançamento foi no dia 25 de maio de 1995 , às $10 \mathrm{~h}$ da manhã, com a participação da imprensa e um computador emprestado da Sun (DINIZ, MEIRELLES e FONSECA, 2010, p. 224).
\end{abstract}

Em 1996, poucos meses depois do lançamento do BradescoNet, o banco avançou novamente no território virtual e tomou dianteira em relação a seus concorrentes tornando-se a primeira instituição financeira do país a lançar um serviço

\footnotetext{
${ }^{115}$ No caso especificamente do Bradesco, desde 1992, com o fim da reserva de mercado, como visto no capítulo 3, e o encerramento das atividades da Digilab, uma de suas fornecedoras de soluções tecnológicas, o banco vinha apostando em canais de atendimento oferecidos pelo videotexto, como o TeleBradesco Residência e o TeleBradesco Empresas (DINIZ; MEIRELLES; FONSECA, 2010, p. 224). ${ }^{116}$ Diniz (2000) elenca ao menos três vantagens que as instituições bancárias poderiam obter ao oferecer seus serviços de homebanking na internet: não seria mais necessário oferecer treinamento a seus correntistas para utilizarem softwares específicos; também não haveria necessidade de substituição ou atualização dos programas distribuídos; e, por fim, os bancos teriam maior controle de sua imagem e marca, uma tarefa mais difícil quando se utilizavam soluções tecnológicas desenvolvidas por outras empresas (DINIZ, 2000, p. 31-32).
} 
de internet banking ${ }^{117}$, o quinto deste tipo no mundo ${ }^{118}$ (GATES, 1999). Tratava-se, ainda conforme explicação de Gregio (DINIZ; MEIRELLES; FONSECA, 2010, p. 226), de uma demanda dos próprios correntistas que, pouco depois de acessarem o site do banco já desejavam visualizar extratos na internet. Desta forma, "a pressão dos usuários e a evolução de mecanismos de segurança para transações feitas via internet [...] criaram a oportunidade para que alguns bancos pioneiros passassem a oferecer a seus clientes o acesso a informações de suas contas, através da Web, ainda em meados da década passada [1990]" (DINIZ; MEIRELLES; FONSECA, 2010, p. 260).

No ano seguinte, dois bancos brasileiros também apresentaram sistemas de internet banking a seus correntistas, o Banco do Brasil e o Banco do Estado do Ceará. Além deles e do Bradesco, outras dezesseis instituições financeiras já dispunham aos internautas informações sobre seus produtos e serviços na internet: Banco de Boston, BNDES, Banespa, Banrisul, Caixa Econômica Federal, CCF Brasil, Excel Econômico, Graphus, HSBC-Bamerindus, Icatu, Itaú, Multiplic, Pontual, Real, Sistema Financeiro Rural e Unibanco (APLICAÇÃO..., 1997).

No final da década de noventa, em 1998, o total de usuários do internet banking em quatro grandes instituições bancárias do país já se aproximava de dois milhões: 770 mil do Bradesco (o que significava 9,5\% dos clientes desse banco), 711 mil do Banco do Brasil (6\% dos correntistas), 400 mil do Itaú (6\%) e 100 mil do Unibanco (3\%). O número de transações realizadas no ambiente virtual não apresentou, no entanto, crescimento nas mesmas proporções: nesse mesmo ano, apenas 0,5\% das 12,8 bilhões de operações bancárias contabilizadas haviam sido realizadas na internet - um total de 640 milhões de transações (PADUAN, 1999).

O quadro foi revertido nos anos seguintes, conforme foi apresentado na seção anterior, quando se constata, entre $2001^{119}$ e 2002, um avanço de $178 \%$ no volume de transações, totalizando 2,2 bilhões de operações. Igualmente, o número de usuários dos

\footnotetext{
${ }^{117}$ Em Diniz, Meirelles e Fonseca (2010), Wilson Ruggiero, ex-presidente da Scopus Tecnologia, conta que os dirigentes do Bradesco anteciparam o lançamento do internet banking do banco ao saber que o Itaú estava próximo de lançar seu sistema.

${ }^{118} \mathrm{Um}$ dos primeiros bancos a oferecer internet banking foi o estadunidense Wells Fargo, em maio de 1995. No primeiro dia em que o serviço foi disponibilizado na internet, um total de 1.500 correntistas se registraram no sistema virtual do banco (DINIZ, 2000).

${ }^{119}$ Nesse ano, o número de usuários regulares ou ocasionais de internet banking no Brasil (49\%) superou o valor apurado em nações mais ricas, como Canadá (45\%), Estados Unidos (29\%) e Japão (14\%), segundo pesquisa mundial realizada pela América Online (POLONI, 2001).
} 
serviços bancários na internet apresentou considerável crescimento já nos primeiros anos dessa década: em 2000, já havia 8,3 milhões de usuários, em 2001, 13 milhões, e em 2002, 14,9 milhões de usuários (DINIZ, 2004).

Cumpre apontar nesse cenário, apenas a título de contextualização, que de 1995 ao final da década de noventa, a página eletrônica do Bradesco ${ }^{120}$ evoluiu de maneira significativa: passou de um simples repositório de informações institucionais para um grande endereço de comércio eletrônico na internet. No final do ano de 1999, os clientes do banco podiam fazer compras online dentro do site da instituição escolhendo produtos de catálogos de mais de 200 lojas conveniadas. O pagamento era feito por uma transação imediata da conta do cliente para a da loja vendedora, sem que fosse necessário informar o número do cartão de crédito (GATES, 1999; PADUAN, 1999).

Esse protagonismo do Bradesco no ambiente virtual na segunda metade da década de noventa, com o lançamento do primeiro site comercial brasileiro e o quinto serviço de internet banking do mundo, rendeu à instituição bancária elogiosas passagens em Bill Gates (1999), como se sabe, um dos maiores nomes da computação na atualidade:

\begin{abstract}
Embora os bancos sempre tenham sido grandes usuários da tecnologia da informação, não têm a reputação de inovadores ou chegada rápida ao mercado com novos programas e serviços, por terem negócios extremamente controlados. O Bradesco, maior banco do Brasil, com 20 milhões de clientes, é uma exceção notável. Quase desde sua criação, essa instituição financeira fez do princípio "chegar primeiro ao mercado" praticamente um mantra. [...] O Bradesco é conhecido por outros bancos como "o banco para se vencer no Brasil" porque usa tecnologia para desenvolver soluções inovadoras para os clientes com mais rapidez que seus concorrentes (GATES, 1999, p. 148-149).
\end{abstract}

Em seu livro “A empresa na velocidade do pensamento" (1999), Gates também destacava algumas características do embrionário mercado bancário online nacional. Segundo o autor, os serviços de internet banking teriam 'pegado mais rápido' no Brasil que em qualquer outro país. Além disso, devido ao histórico de inflação, os bancos

\footnotetext{
${ }^{120}$ De acordo com uma pesquisa realizada pelo Ibope eRatings (instituto criado numa parceria entre o Ibope e a americana ACNielsen), em setembro de 2000, o "bradesco.com.br" era a quarta página com maior número de visualizações no Brasil, com 118,4 milhões de acessos. O site do banco perdia para o UOL (486 milhões), BOL $(168,8)$ e Terra $(128,4)$ (NOGUEIRA; VARGAS, 2000).
} 
brasileiros apresentavam, na avaliação de Gates ${ }^{121}$, maior capacidade de manter informações atualizadas sobre as contas de seus correntistas do que seus congêneres estadunidenses e do resto do mundo (GATES, 1999, p. 149-150).

No ano de 1999, há um terceiro fato que marca o interesse crescente dos bancos nas possibilidades oferecidas pela rede mundial de computadores. Nessa data, o Bradesco anunciou que ofereceria a seus correntistas acesso gratuito à internet. Mais uma vez, o banco desempenhou papel protagonista: não era apenas a primeira instituição financeira a ofertar tal serviço, mas a primeira empresa do país a entrar nesse mercado $^{122}$ (YATES, 2002; VIEIRA, 2003; FERRARI, 2014).

A iniciativa do banco, lançada num primeiro momento exclusivamente aos clientes do Estado de São Paulo em 13 de dezembro de 1999, chamava-se "Rede acesso grátis". De acordo com o regulamento da campanha, quanto maior fosse o relacionamento do cliente com o banco na internet, ou seja, quanto mais tempo dispendesse utilizando os serviços de internet banking do Bradesco, mais horas de acesso grátis ele receberia para navegar na internet (POR TRÁS..., 2000; VIEIRA, 2003).

O arranjo econômico arquitetado para sustentar esse pioneiro modelo de acesso grátis oferecido pelo Bradesco no país não foi, até onde é possível verificar, propriamente esclarecido. Segundo Vieira (2003), a infraestrutura era oferecida a partir de parceria com alguns fornecedores do Bradesco, "um dos maiores usuários de tecnologia do país" (VIEIRA, 2003, p. 130). Certamente, assim como ocorreu na mais recente campanha de internet grátis do banco, tais questões envolvem sigilo comercial e estratégias empresariais que não apresentam registro na imprensa ou não estão disponíveis ao acesso irrestrito do público.

\footnotetext{
${ }^{121}$ Bill Gates teve participação destacada em outros episódios da trajetória da automação bancária e do desenvolvimento da internet no Brasil. Em 1994, o fundador da Microsoft gravou um comercial para o Unibanco em que elogiava o seu terminal de autoatendimento (DINIZ; MEIRELLES; FONSECA, 2010, p. 193). Cinco anos mais tarde, em 1999, a Microsoft anunciou um acordo com as organizações Globo para conjuntamente ofereceram serviço de banda larga para os internautas brasileiros. O primeiro passo nessa parceria foi o investimento da empresa estadunidense de US\$ 126 milhões na Globo Cabo S.A, multioperadora que, à época, ocupava a liderança em TV a cabo no Brasil (GLOBO..., 1999; BOLAÑO et al., 2007, p. 205).

122 Após o Bradesco ter anunciado que forneceria internet gratuita a seus correntistas, suas ações tiveram valorização considerável no mercado: em apenas cinco dias, as ações preferenciais do banco subiram $14 \%$, enquanto o Ibovespa apresentou queda de $3,1 \%$. Um mês após o anúncio, a valorização dos papeis do banco chegou a $25,1 \%$, contra $10,3 \%$ do Ibovespa (INTERNET..., 2000).
} 
Fato é, no entanto, que em pouco tempo, a campanha do banco logrou sucesso e atraiu o interesse de seus correntistas: em apenas um mês, o Bradesco recebeu 43 mil solicitações de registro junto ao internet banking, enquanto a média verificada em 1999 havia sido de 30 mil pedidos (VIEIRA, 2003). Além da grande aceitação por parte dos correntistas, outras empresas se lançaram no mercado de internet grátis. Pouco após o Bradesco anunciar o "Rede acesso grátis", Unibanco e Banco do Brasil apresentaram ofertas com condições regulamentares ligeiramente diferentes: o primeiro não limitava a quantidade de horas que seria franqueada aos correntistas e o banco público estabelecia um total de cinco horas mensais a seus clientes (PANTOJA; FERREIRA, 2000; VIEIRA, 2003).

Essas três instituições bancárias se somavam, nos anos 2000, a uma considerável lista de provedores de acesso gratuito que surgiram no país, tais como NetGratuita (do UOL), Grátis 1 (do grupo StarMedia), Católico ${ }^{123}$ (ligado à Arquidiocese de Porto Alegre), BRFree, Tutopia, Yoda!, Super11.net e iG (VIEIRA, 2003; BOLAÑO et al., 2007). Conforme visto no capítulo anterior, tratava-se do reflexo de um fenômeno observado no cenário internacional.

Para compreender a função de tais provedores e o interesse que despertavam no mercado, é preciso lembrar que, no começo dos anos 2000, a topologia de acesso à internet se dava, de maneira simplificada, em duas camadas. Na primeira, estavam os usuários que, além do computador, precisavam dispor de uma linha telefônica, que custava na casa de milhares de reais, e contratar o serviço de conexão oferecido por provedores de acesso à rede. Eram essas empresas, situadas numa segunda camada, que detinham a infraestrutura técnica capaz de conectar seus clientes à rede mundial de computadores. Para isso, esses provedores de acesso investiam em modems, computadores e servidores e realizavam contratos com a Embratel (em âmbito nacional) e com operadoras estaduais (PRESCOTT, 2015).

Com o surgimento dos provedores gratuitos, os internautas livravam-se de realizar pagamentos às empresas de provimento de acesso, mas, em todo caso, deveriam arcar com as despesas geradas pelos pulsos telefônicos consumidos durante o tempo

\footnotetext{
${ }^{123}$ Além da venda de espaços publicitários, o modelo de financiamento do provedor gratuito oferecido pela Arquidiocese de Porto Alegre baseava-se na comercialização de objetos religiosos, como terços, bíblias e velas (IGREJA..., 2000).
} 
em que se mantivessem conectados (POR TRÁS..., 2000). A figura 4 representa, em linhas gerais, a hierarquia de acesso à internet do começo dos anos 2000:

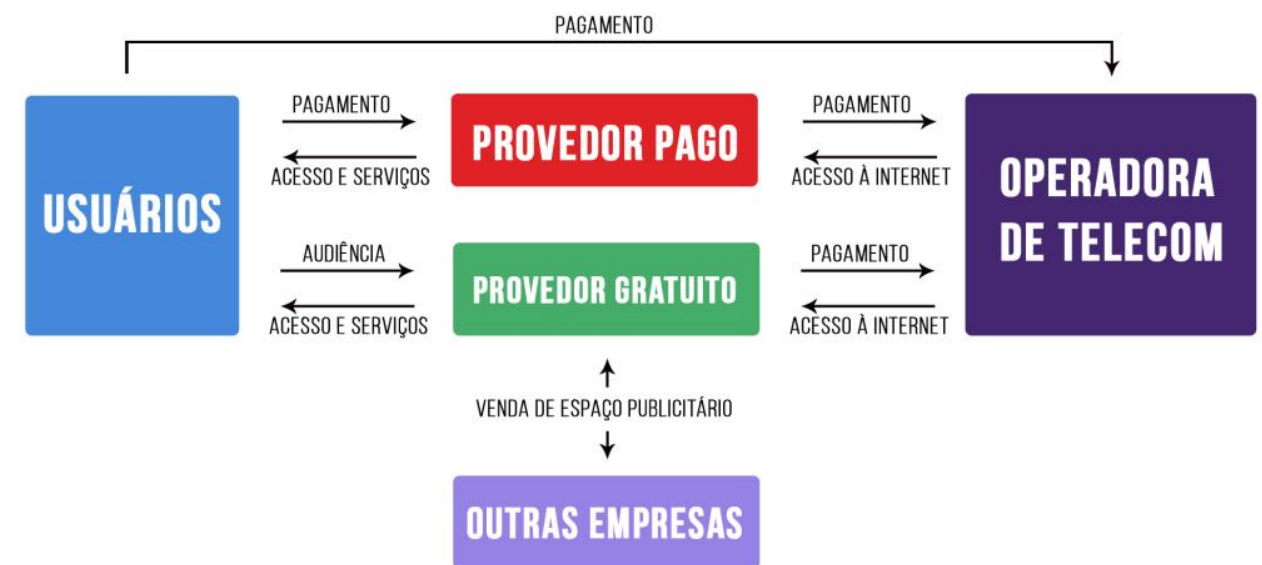

Figura 4 - Hieraquia de acesso à internet nos anos 2000 Fonte: Elaborada pela autora

Enquanto os provedores de acesso à internet pagos se sustentavam a partir de receitas geradas com a venda de produtos e serviços, tais como conta de e-mail, hospedagem de homepages, acesso a conteúdo informativo de portais e newsletters personalizadas, os provedores gratuitos se apoiavam, num primeiro momento, na comercialização de espaços publicitários. Com o passar do tempo, outras fontes de receita passaram a ser introduzidas, como a cobrança de serviços de maior valor agregado e venda de produtos de terceiros, num sistema de comissionamento (YATES, 2002).

É necessário observar que o fluxograma apresentado acima, naturalmente uma abreviação do complexo panorama que se desenhava no mercado à época, deve ser problematizada quando se considera a controversa atuação do iG (sigla inicialmente atribuída a Internet Grátis), lançado em janeiro do ano $2000^{124}$ e que tinha como sócios a Telemar e mais cinco grupos também ligados à companhia telefônica, entre eles a GP Investimentos e o Banco Opportunity ${ }^{125}$ (VIEIRA, 2003; BOLAÑO et al., 2007).

\footnotetext{
${ }^{124} \mathrm{O}$ lançamento do iG, inicialmente previsto para março de 2000, foi antecipado para janeiro do mesmo ano, depois que o Bradesco anunciou sua internet grátis (VIEIRA, 2003).

${ }^{125}$ Como lembra Costa (2014), o Opportunity, fundado em 1994, aproveitou-se em seus primeiros anos de atuação do conhecimento e expertise de Pérsio Arida, economista que participou da equipe governamental que elaborou o Plano Real. Controlado por Daniel Dantas, o banco cresceu 144\% durante o primeiro mandato do ex-presidente Fernando Henrique Cardoso. Ainda conforme explicação contida
} 
A missão da empresa, conforme foi apresentado a seus acionistas e investidores, era desenvolver um grande portal, de alcance nacional, com capacidade de atrair o maior número de usuários no menor tempo possível (FERRARI, 2014). Oficialmente, o iG informava que seu modelo de financiamento era baseado na venda de espaço publicitário e serviços, "igual à televisão da década de 1950", conforme declarou o então presidente da empresa, Nizan Guanaes, no ano 2000 (VIEIRA, 2003, p. 145).

Ocorre que, em 2002, conforme explicam Bolaño et al. (2007), foi revelado por reportagem do jornal Folha de S. Paulo que o provedor não seria sustentado economicamente apenas pela verba publicitária. De acordo com a referida matéria da jornalista Elvira Lobato, em contrato assinado em março de 2001, a Telemar havia se comprometido a fornecer ao provedor conexão à internet gratuitamente e dividir, em percentuais decrescentes ao longo de quatro anos, as receitas geradas pelas ligações dos usuários do iG (BOLAÑO et al., 2007, p. 223). Tal informação acrescentaria ao diagrama um fluxo de recursos partindo da operadora de telecomunicação ao provedor gratuito e, no mercado, acarretaria possíveis desequilíbrios econômicos, considerando o capital e aporte financeiro das empresas do setor.

Em Vieira (2003), Matinas Suzuki Junior, jornalista que participou da criação do iG e chegou a ocupar a presidência executiva do portal, esclareceu que, de fato, a empresa buscava ser desde seu início uma "extensão do negócio de telecomunicações":

O iG nasceu de uma ideia da GP e do Opportunity e sempre esteve $100 \%$ ligado à visão que eles tinham sobre o futuro das empresas de telecomunicações no Brasil, uma vez que eles são acionistas majoritários da Telemar e da Brasil Telecom. O embrião da ideia, na verdade, nasceu na Brasil Telecom e depois foi tomando corpo através dos acionistas. Eles sabiam que, pela maneira como a privatização havia sido feita no Brasil, [...] a internet ocuparia um espaço importante para a proteção do mercado. E também sabiam que o modelo gratuito, que eles haviam estudado como ninguém na Inglaterra e nos Estados Unidos, casava muito bem como uma extensão do negócio de telecomunicações. [...] Se você não trabalha em conjunto com as TELCOS [operadoras de telecomunicação], sua competitividade é baixa. Os investimentos são altos, os custos são

em Costa (2014), a estratégia de atuação do Opportunity baseava-se na política de juros altos e estoque de títulos públicos. Depois, "conjuntamente com fundos de pensão de empresas estatais, o banco investiu pesado nos negócios de privatizações do governo FHC. Comprou participações da Companhia Vale do Rio Doce e de empresas do Sistema Telebrás" (COSTA, 2014, p. 329). 
altos e o provimento não é seu core business, mas sim o core business das TELCOS (VIEIRA, 2003, p. 141-143).

A parceria estratégica entre a Telemar e um provedor de acesso grátis, quais sejam os reais acordos e parcerias financeiras e tecnológicas firmados, foi reproduzido por outras operadoras de telecomunicação do Brasil que, em pouco tempo, lançaram no mercado novos provedores de acesso gratuito à internet, tais como Ibest (da Brasil Telecom), Pop (GVT) e iTelefônica (Telefônica) (BOLAÑO et al., 2007, p. 223).

Diante da concorrência imposta pelas dezenas de ofertas de internet grátis no começo dos anos 2000, os pequenos e médios provedores, organizados na Abranet, mobilizaram diversas contestações jurídicas contra o modelo de provimento de acesso gratuito à rede no país. Interessa para o desenvolvimento desta dissertação destacar apenas uma dessas tantas ações da Abranet: em janeiro de 2000, a associação protocolou uma representação na Secretaria de Direito Econômico do Ministério da Justiça (SDE/MJ) questionando, entre outras coisas, a conduta do Bradesco e do Unibanco no mercado de acesso à internet.

Em linhas gerais, a Associação alegava que a atuação dos bancos nesse setor configurava uma infração à ordem econômica. Conforme argumentava a entidade, a empresa Telecomunicações de São Paulo (TELESP), controlada desde 1998 pela espanhola Telefônica ${ }^{126}$, realizava acordos anticoncorrenciais com os dois bancos "em desacordo com o princípio da isonomia no oferecimento de infraestrutura de rede". Alegavam, desta maneira, que tais condições contratuais deveriam ser estendidas a todos os provedores privados.

Em sua defesa, o Bradesco argumentava que não pretendia entrar no ramo de acesso à internet. Segundo o banco, o acesso à rede era um "meio" de operacionalizar serviços bancários e não um "fim" da instituição e que "em nenhum momento [...] objetivou monopolizar o serviço de provimento de acesso à internet”. A defesa do Bradesco dizia ainda que não era indevidamente beneficiado em acordos com a

\footnotetext{
${ }^{126}$ A representação foi protocolada pela Abranet em 14 de janeiro de 2000 na Secretaria de Direito Econômico do Ministério da Justiça. O relatório da averiguação preliminar instalada no Cade, de número 08012.00003872000-03, com trechos do questionamento da Abranet e das defesas do Bradesco, Unibanco e Telefônica, encontrava-se disponível, até pelos menos 20 de janeiro de 2016 no site do Conselho. O endereço com o devido processo já não se encontra mais disponível. Uma cópia do documento está arquivada no acervo da autora.
} 
Telefônica, uma vez que todos os serviços de infraestrutura de rede eram oferecidos por meio de contratos com a empresa de telecomunicação.

Esse imbróglio só foi resolvido em junho de 2007, quando a Secretaria de Direito Econômico do Ministério da Justiça decidiu que o fornecimento de internet aos correntistas do Bradesco e Unibanco não infringia a ordem econômica. O parecer da SDE/MJ foi chancelado em julho do mesmo ano pela Procuradoria do Conselho Administrativo de Defesa Econômica, que recomendou o arquivamento da representação da associação.

Como se nota até aqui, os provedores de acesso grátis tiveram papel bastante destacado no desenvolvimento da internet no país no começo dos anos 2000. Diferentes players se lançaram no mercado para conquistar uma larga base de assinantes, quais fossem seus objetivos e interesses nesse negócio - aumentar o número de usuários de internet banking, deter audiência para comercialização de espaços publicitários ou até mesmo explorar um novo nicho de mercado que se apresentava. Apesar de bastante movimentado, esse capítulo da história da internet durou pouco tempo.

Segundo Yates (2002), de um grupo de dezessete provedores (entre exclusivos, pagos, gratuitos e híbridos) surgidos no começo dos anos 2000, apenas um deu continuidade ao acesso grátis, o Ibest. Outros seis já haviam encerrado suas atividades em agosto de 2002; cinco haviam passado de um modelo gratuito para o híbrido, combinando serviços gratuitos e pagos; e um havia sido vendido a outra empresa. Bolaño et al. (2007) apresentam dados ligeiramente diferentes que apontam, contudo, para o mesmo cenário: de acordo com os autores, nenhum dos onze provedores de acesso grátis surgidos no começo dos anos 2000 permaneceram em funcionamento até dezembro de 2002.

No mercado estrangeiro de provedores gratuitos o cenário era semelhante: nos Estados Unidos, em um intervalo de dois anos, de 2000 a 2002, 316 das 343 empresas que ofereciam internet gratuita fecharam as portas por dificuldades financeiras (INTERNET..., 2003). Dos mais de 500 provedores que ofereciam conexão grátis na Inglaterra, menos de 20 continuaram no negócio gratuito no começo de 2003 (APESAR..., 2003).

Conforme sintetiza Yates (2012), uma combinação de fatores levou à “derrocada" da grande maioria dos provedores de acesso logo no começo dos anos 
2000: "custos crescentes, ausência de diferenciais competitivos e matriz de receita insuficiente, os quais tiveram seus efeitos amplificados pela crise internacional dos mercados virtuais protagonizada pela NASDAQ" (YATES, 2012, p. 135). Na avaliação do autor, o mercado também foi abalado pela entrada de bancos, operadoras de telecomunicação e empresas midiáticas, uma vez que, com isso, foi reduzida a base de usuários e a fonte de receita dos provedores já existentes (YATES, 2012, p. 132).

Encerrado este polêmico capítulo da trajetória da internet no Brasil, mais de uma década depois, em 2014, o Bradesco retornou ao mercado de internet grátis. O banco lançou em março daquele ano o "Acesso Gratuito ao Bradesco Celular", campanha de internet patrocinada que permite a seus correntistas que têm contas prépagas ou pós-pagas nas operadoras telefônicas Claro, Oi, Tim e Vivo acessarem serviços de internet banking a partir do celular, seja por meio do aplicativo do banco ou pelo navegador de internet do smartphone, sem que o tráfego de dados dessa navegação específica seja descontado de seus pacotes de dados de internet móvel.

Tal campanha é atualmente considerada uma prática de Zero Rating (Tarifa Zero) denominada de acesso patrocinado, que, de acordo com explanações da Anatel, ocorre quando um provedor de aplicação e conteúdo (o Bradesco) paga diretamente a prestadoras (no caso, as quatro já citadas empresas de telefonia móvel do país) pelo tráfego gerado por seus usuários (os correntistas do banco) (AGÊNCIA NACIONAL DE TELECOMUNICAÇÕES, 2015).

Mais uma vez, em que pese a recente aprovação e regulamentação do Marco Civil da Internet (Lei 12.965/14), em abril de 2014 e maio de 2016, respectivamente, e os atuais debates a respeito da neutralidade de rede, poucas são as informações disponíveis sobre o "Acesso Gratuito ao Bradesco Celular". A primeira ordem de esclarecimentos a respeito da internet patrocinada do Bradesco está presente no regulamento ${ }^{127}$ da campanha. Em seu discurso institucional, o banco apresentou três objetivos ao fornecer internet patrocinada a seus clientes: a) proporcionar a primeira experiência de acesso aos serviços disponibilizados no canal Bradesco Celular ${ }^{128}$; b)

127 O regulamento da campanha "Acesso Gratuito ao Bradesco Celular" está disponível em $\langle$ http://www.bradescocelular.com.br/termo/termo_de_uso_acesso_gratuito.pdf〉 Acesso em: 16 nov. 2016.

${ }^{128}$ Além do canal Bradesco Celular, o banco oferece outros três canais de serviços digitais: a) Internet Banking, em que são oferecidos aos clientes mais de 600 produtos e serviços online; b) Fone Fácil, que 
estimular o uso do Bradesco Celular; c) e, por fim, incentivar a adoção dos serviços de mobile banking como "um dos principais meios para movimentação da conta bancária".

Com algumas variações a depender do sistema operacional dos aparelhos celulares (Android, Blackberry, iPhone ou Windows Phone), os principais serviços bancários oferecidos no canal Bradesco Celular são: a consulta de saldo e de extrato da conta e do cartão de crédito de até 12 meses; a solicitação de empréstimos; a compra e venda de ações; e o pagamento de contas por meio de captura e processamento automático do código de barras de boletos e faturas.

Ainda de acordo com o regulamento da campanha, especificamente quanto à gratuidade dos serviços oferecidos, o Bradesco esclarece que o acesso franqueado é restrito ao ambiente da conta bancária e que outros links disponíveis no site do banco ou em seus aplicativos não estão contemplados no "Acesso Gratuito ao Bradesco Celular". No item 5.10 do documento, é informado ainda que "a gratuidade do acesso não interfere na velocidade do tráfego de dados disponibilizados pelas operadoras".

Uma segunda ordem de explanações a respeito da campanha de internet patrocinada do Bradesco pode ser obtida a partir das declarações dadas à imprensa por dirigentes do banco quando a campanha foi lançada, em 2014, e nos anos seguintes. De acordo com o diretor de canais digitais do Bradesco, Luca Cavalcanti, o banco realizou, por um ano, um conjunto de entrevistas com seus clientes antes de criar o "Acesso Gratuito ao Bradesco Celular". O resultado dessa pesquisa indicou que os correntistas que utilizavam internet móvel de planos pré-pagos reservavam seus pacotes de dados para navegar, prioritariamente, em seus aplicativos favoritos (PAIVA, 2014a). Como os serviços de internet banking não constavam nesse rol de navegação priorizada, os correntistas tinham de recorrer a outros tipos de serviços bancários, como as centrais telefônicas e o atendimento pessoal em agências bancárias (KING; SCIAUDONE, 2015). Foi diante desse cenário que o banco decidiu lançar uma campanha de acesso patrocinado à internet.

Para viabilizar o "Acesso Gratuito ao Bradesco Celular", o banco teve de negociar com as quatro maiores operadoras de telefonia móvel do país (Claro, Oi, Tim e Vivo) para que o volume de dados consumidos por seus correntistas, nas condições

permite consulta de saldos e extratos, pagamentos de contas, liberação de empréstimos pré-aprovados, dentre outros serviços; e c) Autoatendimento, que são os caixas automáticos do banco. 
dispostas no regulamento da campanha, não fosse cobrado nas faturas telefônicas. Essas negociações foram as primeiras do gênero no país, ou seja, foi a primeira vez que uma empresa privada remunerou empresas telefônicas para que o pagamento referente ao acesso a determinadas aplicações ${ }^{129}$ não fosse recolhido dos consumidores finais (PAIVA, 2014a; BRONZATI, 2014). Os valores envolvidos nas transações não foram revelados.

Conforme argumentou o diretor de canais digitais do Bradesco, Lucas Cavalcanti, à época do lançamento da campanha, tal tipo de negociação poderia ser explorado comercialmente pelas empresas de telecomunicação do país. Nas palavras do executivo, "as operadoras têm nas mãos agora um novo negócio para ser praticado com grandes empresas e o grande beneficiário disso é o usuário" (PAIVA, 2014a).

Em acordo com a declaração de Cavalcanti, a chefe de publicidade da Telefônica/Vivo à época, Andreza Santana, afirmou em março de 2014 que a "URL patrocinada" seria, em breve, oferecida a outras empresas interessadas em fornecer internet gratuita a seus clientes (PAIVA, 2014b). Tal fato só veio a ocorrer em junho de 2016, quando a campanha "Acesso ao Bradesco Celular" já havia completado dois anos. A operadora de telefonia móvel anunciou um programa de dados patrocinados ${ }^{130}$ em que os clientes detentores de planos pré-pagos e os chamados planos "controle" que visualizam peças publicitárias são bonificados com pacotes de dados pagos pelos anunciantes. De acordo com o regulamento determinado pela Vivo, são as marcas e empresas contratantes desse serviço de internet patrocinados que definem a quantidade de participações, as condições e o volume de dados franqueados aos usuários ${ }^{131}$.

Além do banco e das quatro operadoras, há um sexto ator envolvido no "Acesso Gratuito ao Bradesco Celular”: a Qualcomm, a maior fabricante de chips para telefones celulares do mundo. Segundo informações publicadas pela Bloomberg, agência de notícias especializada na cobertura do sistema financeiro, a empresa teria participado das negociações do banco com as quatro operadoras de telefonia móvel (KING;

\footnotetext{
${ }^{129}$ Segundo o Marco Civil da Internet, Lei $n^{\circ}$ 12.965, de 23 de abril de 2014, "aplicações de internet" são o conjunto de funcionalidades que podem ser acessadas por meio de um terminal conectado à internet.

130 Os termos e condições do "Vivo Dados Patrocinados" estão disponíveis em: < http://interatividade.vivo.ddivulga.com/termos_condicoes.html>. Acesso em: 12 nov. 2015.

${ }^{131}$ A marca Dove, controlada pela Unilever, foi a primeira participante da "Vivo Dados Patrocinados" (AMARAL, 2016).
} 
SCIAUDONE, 2015). O acesso patrocinado, chamado pela fabricante de chip de "0800 de dados" 132 , não traria lucro diretamente à Qualcomm, segundo argumentou o presidente da empresa na América Latina, Rafael Steinhauser. O retorno financeiro viria, ainda conforme explanação do executivo da empresa, a partir da inclusão digital que a internet franqueada potencialmente promoveria: com um possível aumento da demanda por smartphones, as vendas de chips da Qualcomm também cresceriam (PAIVA, 2014c; MEDEIROS, 2014).

Feito esse panorama da complexa trama de atores e interesses envolvidos no modelo de acesso patrocinado elaborado pelo Bradesco, faz-se necessário avaliar, apenas a título de contextualização, alguns dos resultados que o banco observou a partir do lançamento da iniciativa. Como é possível observar na tabela abaixo, em 2013, um ano antes do lançamento do "Acesso Gratuito ao Bradesco Celular", o uso do mobile banking já alcançava números significativos:

Tabela 9 - Bradesco Celular em 2013

\begin{tabular}{lc}
\hline \multicolumn{2}{c}{ Panorama do mobile banking do Bradesco em 2013 } \\
\hline Contas pagas pelo celular & $\mathrm{R} \$ 1,2$ bilhões \\
Transferências via celular & $\mathrm{R} \$ 2,3$ bilhões \\
Volume financeiro transacionado & $\mathrm{R} \$ 5,6$ bilhões \\
Número total de transações & 868 milhões \\
\hline Fonte: Paiva (2014a), Pita (2014) e Bradesco (2016); elaborada pela autora
\end{tabular}

Fonte: Paiva (2014a), Pita (2014) e Bradesco (2016); elaborada pela autora

No ano do lançamento da campanha de acesso patrocinado, em 2014, $9 \%$ das transações bancárias do Bradesco eram feitas por meio dos serviços de celular e 50\%, pelo internet banking. Os caixas eletrônicos representavam 20\% das transações, ou seja, menos da metade da movimentação gerada via internet (BRONZATI, 2014). De acordo com dados divulgados pelo Bradesco ${ }^{133}$, houve um salto de mais de dois bilhões de operações realizadas pelo celular entre os anos de 2014 e 2015, como se observa abaixo.

\footnotetext{
${ }^{132}$ Tal comparação do acesso patrocinado com os serviços de "0800" da telefonia móvel também foi feita pelo diretor de Negócios da Qualcomm Brasil, Oren Pinsky, em entrevista ao UOL. Disponível em: $<$ http://convergenciadigital.uol.com.br/cgi/cgilua.exe/sys/start.htm?UserActiveTemplate=site\&infoid= 41073\&sid=95\#.WC3lm31CiUW >. Acesso em: 17 nov. 2016.

${ }^{133} \mathrm{O}$ relatório com informações institucionais e financeiras do Bradesco, publicado em 28 de novembro de 2016, encontra-se disponível em 〈https://www.bradescori.com.br/site/conteudo/home/default.aspx $>$. Acesso em: 3 dez. 2016.
} 
Ou seja, os números indicam que a campanha do Bradesco, de fato, tem conseguido, junto de outros fatores, incrementar o uso dos serviços bancários via celular, conforme pretendiam os executivos do banco.

Tabela 10 - Transações bancárias do Bradesco realizadas via internet e mobile banking

\begin{tabular}{ccc}
\hline ANO & Transações realizadas pela internet & Transações pelo Bradesco Celular \\
\hline $\mathbf{2 0 1 0}$ & 2,39 bilhões & 33 milhões \\
$\mathbf{2 0 1 1}$ & 2,98 bilhões & 99 milhões \\
$\mathbf{2 0 1 2}$ & 3,64 bilhões & 381 milhões \\
$\mathbf{2 0 1 3}$ & 4,20 bilhões & 868 milhões \\
$\mathbf{2 0 1 4}$ & 4,5 bilhões & 1,9 bilhões \\
$\mathbf{2 0 1 5}$ & 4,6 bilhões & 3,2 bilhões \\
\hline
\end{tabular}

Fonte: Bradesco (2016); elaborada pela autora

Segundo cálculos realizados pelo vice-presidente do Bradesco, Maurício Minas, em agosto de 2015, o volume de transações realizadas via celular deverá dobrar a cada ano. A expectativa de Minas era de que, até o final de 2016, $40 \%$ de todas as transações do banco fossem iniciadas por meio de celulares (KING; SCIAUDONE, 2015). Ainda que tal meta não seja alcançada, os números apurados em 2015 reforçam a tendência de crescimento dos serviços de mobile banking no Bradesco e, numa visão mais alargada, no mercado bancário como um todo.

Diante do que foi exposto até aqui, é possível inferir que o "Acesso Gratuito ao Bradesco Celular" terá uma vigência consideravelmente mais longa do que foi inicialmente previsto no regulamento da campanha, que estabelecia o encerramento da internet móvel franqueada em dezembro de $2015^{134}$. O regulamento dispôs ainda que o fornecimento de internet aos correntistas pode ser interrompido ou finalizado a qualquer tempo, sem aviso prévio. Ao que tudo indica, essas não serão medidas a serem adotadas pelo banco nos próximos meses.

Para que tal análise não seja interpretada apenas como a celebração de uma campanha de marketing bem-sucedida, é preciso lembrar que os investimentos em tecnologias e informatização das atividades bancárias cumprem importante papel na redução de custos dessas atividades, como foi apresentado anteriormente. E tal fato foi,

\footnotetext{
${ }^{134}$ Em dezembro de 2016, o "Acesso Gratuito ao Bradesco Celular" continuava em funcionamento em todo Brasil, de acordo com informações fornecidas pela Central de Atendimento aos Clientes.
} 
naturalmente, considerado pelos agentes envolvidos no "Acesso gratuito ao Bradesco Celular". De acordo com uma pesquisa encomendada pela Qualcomm, enquanto o atendimento em caixa e em centrais telefônicas, serviços que dependem de contratação de funcionários, custam, mais de US\$ 4 ao banco por atendimento, uma transação online não chega a onerar em um dólar o Bradesco. Como sintetizou o vice-presidente do banco, Maurício Minas, em 2015, a estratégia de oferecer internet gratuita a correntistas "se paga facilmente" (KING; SCIAUDONE, 2015).

\subsection{Outras ofertas de internet grátis}

Buscando a mesma equação, supostamente positiva, do banco Bradesco, outras poucas empresas lançaram, recentemente, ofertas de internet grátis aos internautas brasileiros. Soma-se ao "Acesso grátis ao Bradesco Celular" e ao serviço de dados patrocinados da Vivo ${ }^{135}$, o "Navegue Grátis"136 do grupo Netshoes. Essa campanha, que tinha encerramento previsto para janeiro de 2017, ofereceu a gratuidade dos dados consumidos pelos usuários que navegassem nos aplicativos ou nos sites móveis da Netshoes e da Zattini ${ }^{137}$ pelo celular. Mais uma vez, a campanha só foi válida para clientes das quatro maiores operadoras de telefonia móvel do país: Claro, Oi, Tim e Vivo.

Em agosto de 2016, foi a vez da Privalia, um outlet de moda online, lançar seu pacote de internet grátis para acessos feitos somente a partir do aplicativo móvel da empresa. O objetivo da campanha era aumentar as visitas à loja virtual da marca feitas a partir do celular, que, naquele ano, já respondiam por $70 \%$ do total. Conforme foi

\footnotetext{
135 A estadunidense AT\&T oferece, desde janeiro de 2014, um pacote de dados patrocinados semelhante ao da Vivo, o Sponsored Data. Por meio desse serviço, as empresas podem patrocinar o tráfego de dados de determinados conteúdos específicos de sua aplicação, remunerando a AT\&T somente pelo acesso daquele conteúdo. Conforme exemplifica o conteúdo institucional dessa campanha, uma companhia de seguro de saúde poderia, por exemplo, patrocinar a navegação de um vídeo com fins educativos e os dados consumidos apenas na visualização desse conteúdo não seriam descontados do pacote de dados dos usuários. Informações a respeito da campanha da AT\&T estão disponíveis em <http://developer.att.com/apis/sponsored-data $>$. Acesso em: 16 nov. 2016.

$136 \mathrm{O}$ regulamento da campanha encontra-se disponível em: <http://www.netshoes.com.br/naveguegratis/regulamento>. Acesso em: 14 nov. 2016.

${ }^{137}$ Fundada no ano 2000, a Netshoes é uma loja virtual que tem como foco a venda de artigos esportivos. Em 2014, foi lançada a Zattini, uma subsidiária especializada em moda e lifestyle. Atualmente, o grupo tem atuação no Brasil, México e Argentina. Informações a respeito das duas empresas estão disponíveis em: < http://www.netshoes.com.br/institucional/index.jsp>. Acesso em: 14 nov. 2016.
} 
divulgado na imprensa, foi também um dos objetivos da ação fazer crescer o tempo gasto na navegação do aplicativo da Privalia. Diferente das ofertas do Bradesco e do grupo Netshoes ${ }^{138}$, a gratuidade se restringiu aos clientes da TIM e Vivo (PRIVALIA, 2016).

Antes dessas três iniciativas, algumas operadoras de telecomunicação do Brasil chegaram a oferecer planos de internet em que o pacote de dados consumidos em certos sites de redes sociais e ferramentas de mensagem instantânea não seriam cobrados dos clientes. Em junho de 2015, a operadora de telefonia móvel Claro lançou a campanha "Internet Turbinada" para oferecer o acesso gratuito ao Facebook, Twitter e Whatsapp a clientes dos pacotes de dados pré ou pós-pago (DO AMARAL, 2015a). Até outubro de 2015, a operadora TIM apresentava uma oferta semelhante de acesso ilimitado ao Whatsapp a seus clientes.

No cenário internacional, um dos casos de Zero Rating mais controversos e debatidos na atualidade é a plataforma Free Basics.com, uma das iniciativas lançadas pelo Facebook no âmbito do Interner.org ${ }^{139}$. O objetivo do projeto desenvolvido pelo site de rede social é, em linhas gerais, prover acesso gratuito em países subdesenvolvidos a um conjunto de sites e serviços específicos, entre eles, o próprio Facebook. Para isso, conta com a parceria de empresas provedoras de serviços de comunicação móvel e de tecnologia, como Ericsson, Nokia e Qualcomm ${ }^{140}$.

Em fevereiro de 2016, o projeto sofreu um grave contratempo no cenário mundial quando a Autoridade Reguladora de Telecomunicações da Índia determinou que as operadoras que atuam no país estão proibidas de cobrar tarifas diferenciadas de acordo com o conteúdo ou aplicação acessada pelos internautas e de oferecerem pacotes de Zero Rating. Para o órgão regulador indiano, "as operadoras de telefonia celular não

\footnotetext{
${ }^{138}$ Para lançarem suas ofertas de internet móvel grátis, Netshoes e Privalia contaram com a atuação da empresa MUV (sigla para Mobile Unique Vision). Com atuação no Brasil e nos Estados Unidos, essa empresa foi responsável por intermediar os acordos com as companhias telefônicas (PAIVA, 2016e). $139 \mathrm{O}$ projeto Internet.org foi lançado em 2013. Em um ano, a iniciativa do Facebook já estava em funcionamento em 17 países na Ásia, na África e na América Latina. Mais informações estão disponíveis em <https://www.facebook.com/Internetdotorg/about/?ref=page internal> <https://info.internet.org/pt/approach/>. Acesso em: 3 dez. 2016.

${ }^{140} \mathrm{O}$ projeto de internet gratuita do Facebook já está em funcionamento na Colômbia e na Guatemala, desde janeiro e abril de 2015, respectivamente. Apesar de não haver previsão de lançamento do Freebasics.com no Brasil, Mark Zuckeberg, diretor do Facebook, já declarou seu interesse em implantar o projeto no país em um encontro com a presidente Dilma Rousseff no Foro Empresarial, reunião paralela à $7^{\text {a }}$ Cúpula das Américas, em abril de 2015 (UM ANO..., 2015; ALENCASTRO, 2015).
} 
deveriam ter a permissão de 'moldar a experiência de internet dos seus usuários' ao dar acesso a eles apenas para serviços específicos, como o que acontece no Free Basics" (SERVIÇO, 2016).

Interpretação semelhante teve o Ministério Público Federal no Brasil, em fevereiro de 2016, ao emitir uma nota técnica em que argumenta que a iniciativa do Facebook feria o princípio de neutralidade de rede. No ano anterior, o órgão já havia se posicionado em relação ao Internet.org comparando-o a uma "propaganda para a venda de acesso à internet com roupagem de acesso livre à rede" (FERRARI, 2016).

Como se observa no cenário brasileiro, ainda que as campanhas de internet grátis tenham sido objeto de preocupação na regulamentação do Marco Civil, como foi visto no capítulo dois, são poucas as ofertas de tal tipo em vigor no país: até o último bimestre de 2016, estavam disponíveis aos internautas brasileiros de maneira contínua as campanhas do Bradesco, Netshoes e Privalia, Longe de significar um esforço inócuo do legislador, a escassez de planos pode revelar um cenário bastante alarmante para o futuro próximo: quem serão as empresas com capacidade de realizar acordos e contratos da monta do que foi feito, por exemplo, pelo Bradesco para oferecer internet grátis a seus clientes? 


\section{CONSIDERAÇÕES FINAIS}

Esta dissertação buscou apresentar as afinidades existentes entre o desenvolvimento da internet e da informatização dos bancos, ao reconstituir a percurso histórico de cada uma dessas duas trajetórias. Ao longo do texto e também na "Cronologia do desenvolvimento da internet e da automação bancária brasileira" apresentada no apêndice deste trabalho, procuramos resgatar dados e informações que evidenciam as conexões, os pontos de aproximação e de distanciamento entre os percursos em questão.

Em destacado, evidenciamos, no nosso recorte empírico, as duas ofertas de acesso grátis oferecidas pelo Bradesco em 1999 e 2014. O objetivo era lançar luz em iniciativas de um dos maiores bancos do Brasil que se baseavam num modelo específico de internet (a internet grátis para clientes) e se tornaram mais um expediente do intenso processo de digitalização das atividades bancárias.

No capítulo dois, que reserva considerações a respeito da moldura teóricometodológico desta dissertação, buscamos apresentar ao leitor, além dos fundamentos gerais da Economia Política da Comunicação, um diálogo entre as contribuições de César Bolaño, Ruy Sardinha Lopes, Manuel Castells, Dan Schiller e Robert McChesney, a respeito do surgimento das tecnologias da informação e da comunicação. Conforme procuramos demonstrar, se por um lado autores como Bolaño (2000b) e Lopes (2008) contextualizam o desenvolvimento das TIC na esteira de grandes mudanças e acontecimentos políticos e econômicos desencadeados a partir do final dos anos 1960, Castells (1999, 2003, 2012, 2015), por sua vez, destaca em seu quadro teórico que tais tecnologias estão relacionadas a uma nova estrutura social, a "Sociedade em Rede". Ao fazer isso, o autor minimiza, em nossa avaliação, importantes aspectos macrossociais que são abordados nas obras de Bolaño (2000b), Lopes (2008), Schiller (2002) e McChesney (2013).

O estudo dos diferentes estágios históricos da internet, seguindo a periodização proposta por Bolaño et al. (2007), nos mostrou o quadro geral do desenvolvimento da rede em cada período. Na primeira década da ARPANET, rede predecessora da internet, houve uma expansão lenta e gradual, com modelo de financiamento sustentado por recursos públicos. Já numa segunda fase do desenvolvimento da rede mundial de 
computadores, na década de oitenta, as principais inovações tecnológicas criadas buscavam abrir a rede de computadores a um número maior de usuários e países. $\mathrm{Na}$ década seguinte, duas mudanças de ordem política e econômica, marcam o começo da terceira fase: a desativação da ARPANET (em 1990) e a privatização da NSFNET (1995).

Nesse terceiro estágio da internet observou-se a expansão global da internet e a consolidação da lógica mercantil. Foram criadas diversas aplicações comerciais e tecnologias para facilitar a navegação dos novos usuários. Como demonstramos no texto acima, foi a partir da terceira fase da internet que ocorreram grandes fusões de empresas de internet com companhias midiáticas. No ano 2000, por exemplo, AOL e Time Warner se juntaram e, pouco tempo depois, também as empresas Vivendi, Canal Plus e Seagram.

Ainda na terceira fase, houve o estouro da bolha especulativa da internet e, como um dos resultados desse movimento, um considerável enxugamento do setor: até o começo de 2001, foram fechadas 270 empresas.com e passava de 10 mil o número de demissões de trabalhadores.

Nesta dissertação, avançamos na periodização proposta em Bolaño et al. (2007) e apresentamos a quarta fase de desenvolvimento da internet, que tem seu início no ano 2000 e se estende até a atualidade. Em nossa análise, caracterizam o desenvolvimento da rede neste período a popularização do acesso móvel à internet, o surgimento dos sites de redes sociais e o avanço intenso do volume de negócios e vendas realizados em ambiente online.

Em 2015, de acordo com dados da União Internacional das Telecomunicações, passava de três bilhões o número de usuários conectados pela internet e as assinaturas de banda larga móvel atingiram $47 \%$ da população. De acordo com dados da Ecommerce Foundation, o comércio eletrônico mundial somou US\$2,24 trilhões. Além desses volumosos números, destacamos na quarta fase da internet o desenvolvimento da Internet das Coisas e de tecnologias baseadas em Big Data e as primeiras conexões realizadas do espaço. Se na fase passada houve a robusta expansão da rede em número de países e usuários, no quarto estágio a internet caminha para se tornar ubíqua.

Também no capítulo três, apresentamos a gestação da internet no Brasil, tema que ainda carece de referências bibliográficas. Ao reconstituir essa trajetória, de seus 
antecedentes históricos até o ano 2000, buscamos estabelecer um painel dos principais eventos da trajetória da rede no país, passando pelos principais marcos da história das telecomunicações e da informática no Brasil. Há, certamente, episódios e acontecimentos dessa narrativa que merecem investigações próprias, que não puderam ser feitas neste texto, considerando o exíguo tempo de um mestrado.

Já no capítulo quatro, apresentamos a trajetória da automação bancária. Da década de sessenta aos anos 2010, reconstituímos, tal como foi feito no capítulo três, o processo de informatização do setor bancário nacional. Conforme buscamos demonstrar, a partir dos anos 2000, quando se inicia o terceiro estágio histórico da rede mundial de computadores, o internet banking passou a ter papel fundamental no desenvolvimento de tecnologias e serviços bancários no Brasil. A partir de 2010, o mobile banking também ganhou centralidade no quadro de inovações do setor financeiro nacional.

Algumas outras observações mais gerais das duas trajetórias analisadas nesta dissertação podem ser assinaladas a partir dos dados listados na tabela que compõe a "Cronologia do desenvolvimento da internet e da automação bancária brasileira":

- Entre a construção de dois importantes computadores da história da informática no Brasil, o Zezinho (projetado em 1961) e o Patinho Feio (1972), ocorreram nos Estados Unidos a criação do Interface Message Protocol e as primeiras demonstrações da Arpanet (ambas em 1969). Enquanto aquele país travava uma disputa espacial com a União Soviética, no Brasil, os governos começavam a adotar o uso do computador: o Estado de São Paulo adquiriu uma máquina em 1957 e, em 1958, o presidente Juscelino Kubitcheck autorizou o governo federal a estudar a utilização do computador no âmbito do Plano de Metas.

- Na década de sessenta, os bancos brasileiros passaram a instalar seus primeiros computadores (Bradesco em 1961; Banco Nacional, 1962; Bamerindus, 1968). No cenário institucional, além do golpe militar, observou-se no Brasil nesse período a criação dos primeiros marcos regulatórios e órgãos responsáveis pelas telecomunicações e informática no país: em 1961, foi criado o CONTEL; em 1964, o Serpro; em 1965, a Embratel; e, na década seguinte, em 1972, foram criadas a Telebras e a Capre. 
- Em 1975, quando ocorreu a primeira demonstração da ARPANET no Brasil, o governo militar começou a adotar medidas de controle às importações. As compras externas do setor da informática passaram a responder por um rígido controle de análise, o que, conforme argumentam as obras consultadas nesta dissertação, contribuiu para o desenvolvimento, amadurecimento e competitividade tecnológica do Brasil. No cenário da automação bancária, destaca-se, naquele mesmo ano, a fundação da Scopus, uma importante empresa nacional do setor de informática. Na década de setenta outras diversas empresas surgiram no país (Prológica e Digirede em 1976; Embracomp, 1977; SID, 1978; Itautec e Digilab, 1979).

- No ano de 1984, em que foi dada a largada para a Reforma das Telecomunicações nos Estados Unidos, com o processo de desmembramento da AT\&T, houve, no Brasil, a edição da Política Nacional da Informática (Lei $\mathrm{n}^{\circ} 7.232 / 84$ ), que buscava estabelecer normas e diretrizes legais para o desenvolvimento da informática no país.

- Entre os anos de 1991 e 1994, que antecederam a privatização da internet e o início da terceira fase de desenvolvimento da rede, ocorreram importantes eventos na trajetória brasileira. Em 1991, houve o esvaziamento da Política Nacional da Informática e o começo do desmonte da reserva do mercado de informática. Foram os primeiros passos rumo ao processo de liberalização e maior integração ao capital estrangeiro no setor de informática que tomou corpo nos anos seguintes, conforme argumenta Bolaño (2003; 2007). O Brasil, que por quase vinte anos adotou rígidas regras de controle de importações, estava pronto para acompanhar nos anos seguinte a consolidação da lógica mercantil da internet, observada na terceira fase da história da rede de computadores.

- No emblemático ano de $\mathbf{1 9 9 5}$, quando há a privatização da espinha dorsal da internet, foi elaborada e publicada no Brasil a Norma 4/1995, que reorganizou a estrutura de exploração e fornecimento da internet no país. Por meio desta regra, foi estabelecido que a internet era um Serviço de Valor Agregado e ficou reconhecido o papel do provedor privado. Conforme apresentado nesta dissertação, o ministro das Comunicações à época, Sérgio Motta, tinha firme convicção de que a internet só teria competitividade se fosse explorada pela iniciativa privada. Não por um acaso, neste mesmo ano de abertura da internet 
no Brasil e no mundo, o banco Bradesco saiu na frente de seus concorrentes e lançou o primeiro site comercial do país e, no ano seguinte, o primeiro internet banking brasileiro - o quinto serviço desse tipo no mundo.

- De 2000 a 2010, no desenvolvimento da internet observou-se, após o estouro da bolha especulativa, o surgimento de diversos sites de redes sociais (Wikipedia em 2001; Fotolog, 2002; Linkedin e MySpace, 2003; Flickr, Orkut e Facebook, 2004; Youtube, 2005). Naquele mesmo período, houve no quadro da automação o crescimento de usuários de internet banking. No Brasil, o número saltou de 8,3 milhões (em 2001) para 14,9 milhões (2003) e, nos Estados Unidos, de 37 milhões (2002) para 53 milhões (2005). Em 2008, foi a vez da crise financeira mundial. Ocorreram naquele ano a fusão do Itaú com o Unibanco e a compra do Nossa Caixa pelo Banco do Brasil.

- Pouco após o lançamento o "Rede Acesso Grátis", em 2002, o número de usuários de internet banking dos bancos chegou a 8,3 milhões de usuários. Já em 2014, quando foi lançado o “Acesso Gratuito ao Bradesco Celular”, os serviços de mobile banking atendiam a 25 milhões de contas no Brasil.

Ao analisar mais detidamente as campanhas de internet grátis do Bradesco, outras considerações foram feitas ao longo deste dissertação. Nos anos 2000, quando foi anunciado o "Rede Acesso Grátis", dezenas de empresas apresentaram seus provedores gratuitos no país. Além do Bradesco, Unibanco e Banco do Brasil também lançaram iniciativas semelhantes. Quinze anos mais tarde, após o lançamento do “Acesso Grátis ao Bradesco Celular”, apenas duas outras empresas ofereceram navegação gratuita a seus clientes. As condições técnicas e os recursos necessários para lançar campanhas de internet gratuita são, naturalmente, bastante diferentes, mas a comparação histórica dos dois cenários nos leva a inferir que o fenômeno de internet grátis não terá a mesma extensão que teve no começo dos anos 2000.

Outra questão que poderá ser aprofundada em investigações futuras é a compreensão que a comunidade jurídica dará aos planos de internet patrocinada nos próximos meses. Como foi apontado na última parte do capítulo dois, o decreto regulamentador do Marco Civil da Internet (D. $n^{\circ}$ 8.871/2016), editado em maio de 2016, vedou práticas entre empresas de telecomunicação e provedores de aplicação que comprometam o caráter público da internet e priorizem o pacote de dados em função 
de arranjos comerciais (art. $9^{\circ}$ ). Ainda que uma possível interpretação do texto da lei aponte a ilegalidade de planos como o "Acesso Gratuito ao Bradesco Celular”, não foi anunciada até o momento nenhuma mudança na campanha de internet grátis do banco.

Para além dessas observações citadas acima, consideramos importante apontar algumas reflexões a respeito do quadro geral de automação e informatização bancária. Ainda que o cenário apresentado no capítulo quatro não esgote a totalidade de inovações incorporadas à operacionalização das atividades financeiras nas últimas décadas, constitui uma evidência bastante clara da importância dos gastos e investimentos em tecnologia do setor bancário. Isso porque há, segundo Diniz, Meirelles e Fonseca (2010) "uma correlação entre estoque de TI [tecnologia da informação] e os rendimentos do setor": "os bancos mais lucrativos e de maior rentabilidade são os que mais investem em TI, ou seja, os bancos que alavancaram mais os seus ativos foram aqueles que mais investiram em tecnologia de informação" (DINIZ; MEIRELLES; FONSECA, 2010, p. 14-15).

Costa (2014) apresenta tal relação de maneira distinta. Segundo o autor, o uso de novas tecnologias foi decisivo, na história dos bancos brasileiros, para manutenção da posição no mercado. A crescente disponibilidade de tecnologias da informação e equipamentos de autoatendimento teria se tornado, na visão do autor, uma barreira tecnológica imposta aos bancos de pequeno e médio porte, em que a "capacitação de seus técnicos especializados e a tecnologia voltada para sua área de atuação eram mais estratégicas do que a disponibilidade de tecnologias para clientes" (COSTA, 2014, p. 273). Segundo o autor, tal barreira tecnológica teria sido imposta às instituições que pretendiam conquistar o mercado de varejo. Os bancos estrangeiros também teriam enfrentado dificuldades análogas na abertura financeira na década de 1990.

Estava fora dos limites deste texto, no entanto, discutir tal tema. Outras questões, igualmente interessantes, tais como o fechamento de agências, a redução do quadro de bancários no Brasil (brevemente apresentado nesta dissertação), a informatização de relações sociais, a expansão e formas de regulação do dinheiro móvel e do virtual, também devem merecer atenção em futuras investigações que pretendam analisar a trajetória da automação e informatização bancária no Brasil. 


\section{REFERÊNCIAS BIBLIOGRÁFICAS}

AGÊNCIA NACIONAL DE TELECOMUNICAÇÕES. Neutralidade de rede: Proposta de Consulta Pública à sociedade sobre a regulamentação prevista no Marco Civil da Internet. Brasília, DF, 2015. Disponível em:

<http://www.anatel.gov.br/dialogo/file/download/157>. Acesso em: 2 de dez. 2016.

ALENCASTRO, C. Dilma e Zuckerberg anunciam parceria para levar internet a brasileiros de baixa renda. O Globo, Cidade do Panamá, 14 abr. 2015. Disponível em:

<oglobo.globo.com/mundo/dilma-zuckerberg-anunciam-parceria-para-levar-internetbrasileiros-de-baixa-renda-15842029>. Acesso em: 2 de dez. 2016.

ANALISTAS comparam protestos no Brasil a Occupy Wall Street. G1, São Paulo, 20 jun. 2013. Disponível em: <http://g1.globo.com/brasil/noticia/2013/06/analistascomparam-protestos-no-brasil-occupy-wall-street.html >. Acesso em: 4 jan. 2017.

AOS 25 anos, fundador do Snapchat é o bilionário mais jovem do mundo. G1, São Paulo, 7 out. 2015. Disponível em:

<http://g1.globo.com/economia/noticia/2015/10/aos-25-anos-fundador-do-snapchat-eo-bilionario-mais-jovem-do-mundo.html>. Acesso em: 4 jan. 2017.

APESAR do acesso "grátis", internauta inglês prefere serviços pagos. UOL, São Paulo, 11 fev. 2003. Disponível em:

<http://noticias.uol.com.br/mundodigital/ultimas/ult1345u36.jhtm>. Acesso em: 2 de dez. 2016.

APLICAÇÃO e pagamentos podem ser feitos pela Web. Folha de S. Paulo, São Paulo, 17 abr. 1997. Disponível em:

<http://acervo.folha.uol.com.br/fsp/1997/04/17/48/\# >. Acesso em: 2 de dez. 2016.

ARAÚJO, L. A. D. D; NETO, P. D. M. L; PONCE, D. A. S. 2006. Competição e concentração entre os Bancos Brasileiros. Revista EconomiA, Belo Horizonte, p. 561-586, set./dez. 2006.

ARRUDA, M. A. N. A embalagem do sistema: a publicidade no capitalismo brasileiro. São Paulo: Duas Cidades, 1985 .

AT\&T confirma compra de Time Warner por US\$ 85,4 bilhões. G1, 23 out. 2016. Disponível em: <http://g1.globo.com/economia/negocios/noticia/2016/10/t-confirmacompra-da-time-warner-por-us-854-bilhoes.html>. Acesso em: 30 jan. 2017.

BANCO criado por BB e Bradesco lança cartão para concorrer com Nubank. IstoÉ, São Paulo, 13 set. 2016. Disponível em: <http://istoe.com.br/banco-criado-por-bb-ebradesco-lanca-cartao-para-concorrer-com-nubank/ >. Acesso em: 2 de dez. 2016. 
BANCO do Brasil testa em seu app o assistente por voz da IBM. Mobile Time, 21 jun. 2016. Disponível em: <http://www.mobiletime.com.br/21/06/2016/banco-dobrasil-testa-em-seu-app-o-assistente-por-voz-da-ibm-o-

watson/442664/news.aspx?_akacao $=3383100 \& \_a k c n t=4 b 5767 d 4 \&$ _akvkey $=\mathrm{f} 923$ \&utm_source=akna\&utm_medium $=$ email\&utm_campaign=MOBILE+TIME+News+ -+21\%2F06\%2F2016+22\%3A09>. Acesso em: 2 de dez. 2016.

BARAN, P \& P. SWEEZY (1966). Capitalismo monopolista. Rio de Janeiro: Zahar, 1978.

BARBOSA, A. Os barões eletrônicos. Veja, 24 fev. 1982. Disponível em $<$ https://acervo.veja.abril.com.br/\#/edition/703?page $=50 \&$ section $=1 \&$ word=automa $\%$ C3\%A7\%C3\%A3o\%20banc\%C3\%A1ria>. Acesso em: 20 out. 2016.

BARBOSA, M. M. Neutralidade de rede: sistematização da produção acadêmica, discussão política no Marco Civil da Internet, e verificação de semelhanças entre os argumentos utilizados. 2015. 146 f. Dissertação (Mestrado em Comunicação) Programa de Pós-graduação em Comunicação, Universidade de Brasília, Brasília, 2015.

BARROS, F. Inovação na veia. Revista .br, out. 2014. Disponível em: <http://www.cgi.br/media/docs/publicacoes/3/cgibr-revistabr-ed7.pdf >. Acesso em: 2 de dez. 2016.

BATISTA, L. Alta do petróleo faz país viver crise anos 1970. O Estado de S. Paulo, 6 set. 2014. Disponível em: <http://acervo.estadao.com.br/noticias/acervo,alta-dopetroleo-fez-pais-viver-crise-nos-anos-1970,10618,0.htm>. Acesso em: 2 dez. 2016.

BELAISCH, A. Do Brazilian Banks Compete?. International Monetary Fund Working Paper, 2003. Disponível em:

<https://papers.ssrn.com/sol3/papers.cfm?abstract_id=879189>. Acesso em: 2 dez. 2016.

BELI, Lucas; DE FILIPPI, Primavera (Orgs.). Net Neutrality Compedium, human rights, free competition and the future of the internet. Suíça: Springer, 2015.

BENAKOUCHE, T. Redes técnicas/ redes sociais: a pré-história da internet no Brasil. Revista USP, São Paulo, p. 124-133, set./nov. 1997.

BERCITO, D. Primavera árabe criou uma geração engajada, diz pesquisadora canadense. Folha de S. Paulo, Madri, 10 fev. 2016. Disponível em:

$<$ http://www1.folha.uol.com.br/mundo/2016/02/1738269-primavera-arabe-criou-umageracao-engajada-diz-pesquisadora-canadense.shtml>. Acesso em: 4 jan. 2017.

BIANCONI, C. Telecom Itália compra 30 pct do capital total da Globo.com. UOL, $1^{\circ}$ jun. 2000. Disponível em: 
<http://noticias.uol.com.br/ultnot/2000/06/01/ult29u775.jhtm>. Acesso em: 4 jan. 2017.

BILTON, N. Why Google Glass broke. The New York Times, 4 fev. 2015. Disponível em: <http://www.nytimes.com/2015/02/05/style/why-google-glassbroke.html?_r=1>. Acesso em: 4 jan. 2017.

BITTENCOURT, R.; RESENDE, T. Projeto que altera Lei Geral de Telecom deve avançar na semana que vem. Valor Econômico, 5 ago. 2016. Disponível em: $<$ http://www.valor.com.br/empresas/4661059/projeto-que-altera-lei-geral-detelecom-deve-avancar-na-semana-que-vem >. Acesso em: 4 fev. 2017.

BOLAÑO, César. Campo Aberto - para a crítica da epistemologia da comunicação. Aracaju: Editora Diário Oficial do Estado de Sergipe, 2015.

. (Org). Comunicação e a Crítica da Economia Política: perspectivas teóricas e epistemológicas. São Cristóvão: Editora UFS, 2008a.

Desafios da Economia Política da Informação, da Comunicação e da Cultura frente às inovações tecnológicas e à mudança social: a atual batalha epistemológica do pensamento crítico latino-americano. In: BRITOS, V. (Org.), Economia Política da Comunicação: estratégias e desafios no capitalismo global. São Leopoldo: Editora Unisinos, 2008b.

. Economia política da Comunicação e da Cultura - breve genealogia do campo e das taxonomias das indústrias culturais. In: ___ ; GOLIN, C; BRITTOS, V. (Orgs.). Economia da Arte e da Cultura. São Paulo: Itaú Cultural; São Leopoldo: Cepos/Unisinos; Porto Alegre: PPGCOM/UFRGS; São Cristóvão: Obscom/UFS, 2010. 2000a.

Indústria Cultural: informação e capitalismo. São Paulo: Editora Polis,

. O fator subjetivo. INTERCOM, São Paulo, 2000b.

Políticas de comunicação e economia política das telecomunicações no

Brasil. Aracaju: Universidade Federal de Sergipe, 2003.

2007.

. Qual a lógica das políticas de comunicação no Brasil?. São Paulo: Paulus,

; CASTAÑEDA, M. A Economia Política da Internet e sua crise. In:

BOLAÑO, César; JAMBEIRO, O.; BRITTOS, V. C. (Org). Comunicação e Cultura

- Dinâmicas globais e estruturas de poder. Salvador: EDUFBA, 2004, v. 01, p. 43-65. 
; CASTAÑEDA, M; VASCONCELOS, D. Para uma análise do desenvolvimento histórico da internet. In: BOLAÑO, César (Org.), Economia Política da Internet. São Cristóvão: Editora UF, 2007, p. 165 a 226.

et al. Economia Política da Internet - Jornalismo online (v. 2). São

Cristóvão: Universidade Federal de Sergipe, 2012.

MASTRINI, G; SIERRA, F. A latin american perspective for the political economy of communications. The Public, v. 11. 2004, n. 3, p. 47-58.

BRADESCO. Apresentação Bradesco, 28 nov. 2016. Disponível em: <https://www.bradescori.com.br/site/conteudo/home/default.aspx >. Acesso em: 2 dez. 2016.

BRADESCO CONCLUI COMPRA do HSBC Brasil e paga R $\$ 16$ bilhões. G1, São Paulo, $1^{\circ}$ jul. 2016. Disponível em <http://g1.globo.com/economia/negocios/noticia/2016/07/bradesco-paga-r-16bilhoes-e-conclui-compra-do-hsbc-brasil.html >. Acesso em: 27 out. 2016.

BRADESCO investe em plataforma digital e acelera digitalização de base física. Época Negócios, 3 jul. 2016. Disponível em:

$<$ http://epocanegocios.globo.com/Empresa/noticia/2016/07/epoca-negocios-bradescoinveste-em-plataforma-digital-e-acelera-digitalizacao-de-base-fisica.html > . Acesso em: 27 out. 2016.

BRADESCO disponibiliza saque sem cartão por NFC. Mobile Time, 26 ago. 2016. Disponível em: <http://www.mobiletime.com.br/26/08/2016/bradesco-disponibilizasaque-sem-cartao-por-

nfc/455125/news.aspx?_akacao $=3651574 \&$ _akcnt $=4 \mathrm{~b} 5767 \mathrm{~d} 4 \&$ _akvkey $=\mathrm{e} 200 \& u \mathrm{t}$ m_source=akna\&utm_medium =email\&utm_campaign=MOBILE+TIME+News++26\%2F08\%2F2016+19\%3A33 >. Acesso em: 2 dez. 2016.

BRIGATTO, G. Bradesco vai testar tecnologia por trás do bitcoin em São Paulo. Valor Econômico, São Paulo, 21 jun. 2016. Disponível em:

$<$ http://www.valor.com.br/empresas/4609273/bradesco-vai-testar-tecnologia-por-trasdo-bitcoin-em-sao-paulo>. Acesso em: 2 dez. 2016.

BRITTOS, V. A economia política da Comunicação no Brasil em perspectiva histórica. In: BOLAÑO, C. (Org.). Comunicação e a crítica da economia política: perspectivas teóricas e epistemológicas. São Cristóvão: Editora UFS, 2008a.

Economia política da Comunicação: estratégias e desafios no capitalismo global. São Leopoldo: Editora Unisinos, 2008b.

BRONZATI, A. Clientes Bradesco ganham internet grátis no celular. O Estado de S. Paulo, 10 mar. 2014. Disponível em: 
$<$ http://economia.estadao.com.br/noticias/negocios, clientes-bradesco-ganhaminternet-gratis-no- celular,179228e>. Acesso em: 23 ago. 2015.

BROWN, D. et al. NASA Successfully Tests First Deep Space Internet. Nasa Press Release Archives, 18 nov. 2008. Disponível em:

<https://www.nasa.gov/home/hqnews/2008/nov/HQ_08-

298_Deep_space_internet.html>. Acesso em: 2 dez. 2016.

BUCCO, R. Consulta sobre neutralidade da rede da Anatel termina com 147 contribuições. Telesíntese, 20 mai. 2014. Disponível em: < http://www.telesintese.com.br/consulta-da-anatel-termina-com-147-contribuicoes/>. Acesso em: 27 out. 2015.

CAIXA eletrônico - Sharp e Bradesco querem liderar o mercado. Veja, 11 nov. 1992. Disponível em:

<https://acervo.veja.abril.com.br/\#/edition/33282?page=92\&section=1>. Acesso em: 2 dez. 2016.

CARVALHO, M. S. R. M. D. A trajetória da Internet no Brasil: do surgimento das redes de computadores à instituição dos mecanismos de governança. 2006. 259 f. Dissertação (Mestrado em Ciências de Engenharia e Sistemas de Computação) Programa de Pós-graduação de Engenharia, Universidade Federal do Rio de Janeiro, Rio de Janeiro, 2006.

CASTELLS, M. A galáxia da Internet: reflexões sobre a internet, os negócios e a sociedade. Rio de Janeiro: Zahar, 2003.

. A Sociedade em rede. São Paulo: Paz e Terra, 1999. (A era da informação: economia, sociedade e cultura; v. 1)

Communication power. New York: Oxford University Press, 2009.

CASTELLS, 2015. O poder da comunicação.

Redes de indignação e esperança: movimentos sociais na era da internet. Rio de Janeiro: Zahar, 2012.

CASTELO, M. Cuidado: zero-rating não é a mesma coisa que dados patrocinados. Mobile Time, 20 jul. 2016. Disponível em:

<http://m.mobiletime.com.br/news/447722>. Acesso em: 2 de dez. 2016.

COMISSÃO aprova mudanças na Lei Geral das Telecomunicações. Agência Senado, 6 jan. 2016. Disponível em:

<http://www12.senado.leg.br/noticias/materias/2016/12/06/comissao-aprovamudancas-na-lei-geral-de-telecomunicacoes >. Acesso em: 4 fev. 2017.

COMITÊ GESTOR DA INTERNET NO BRASIL. Tic Domicílios 2014 - Pesquisa sobre o uso das tecnologias da informação e comunicação nos domicílios brasileiros. 
São Paulo, SP, 2014. Disponível em:

<http://cetic.br/media/docs/publicacoes/2/TIC_Domicilios_2014_livro_eletronico.pdf >. Acesso em: 2 dez. 2016.

CONHEÇA a história do site de vídeos Youtube. G1, São Paulo, 10 out. 2006.

Disponível em: <http://g1.globo.com/Noticias/Tecnologia/0,,AA1306288-

6174,00.html>. Acesso em: 4 jan. 2017.

COSTA, F. N. D. Brasil dos Bancos. São Paulo: Editora da Universidade de São Paulo, 2014.

COUTINHO, M. A sociedade da informação e o determinismo tecnológico: notas para um debate. Líbero, São Paulo, Vol 6, n. 11, p. 82-93.

CRIADOR do termo "internet das coisas" discute comunicação e cotidiano. Portal Brasil, 16 jan. 2015. Disponível em: <http://www.brasil.gov.br/ciencia-etecnologia/2015/01/criador-do-termo-internet-das-coisas-discute-comunicacao-ecotidiano>. Acesso em: 2 dez. 2016.

CYSNE, R. P.; COSTA, S. G. S. D. Reflexos do Plano Real sobre o sistema bancário brasileiro. RBE, Rio de Janeiro, p. 325-346, jul./set. 1997.

DANTAS, M. O crime de Prometeu - Como o Brasil obteve a tecnologia da informática. Rio de Janeiro: Abicomp,1989.

DANTAS, V. Guerrilha tecnológica - a verdadeira história da Política Nacional de Informática. Rio de Janeiro: LCT-Livros Técnicos e Científicos Ed.,1988.

DAQUINO, F. A história das redes sociais: como tudo começou. Tecmundo, 26 nov. 2012. Disponível em: <https://www.tecmundo.com.br/redes-sociais/33036-ahistoria-das-redes-sociais-como-tudo-comecou.htm>. Acesso em: 4 jan. 2017.

DA SILVA, C. L. A. AT\&T quer que empresas patrocinem transferência de dados na internet móvel. UOL, 7 jan. 2014. Disponível em:

<http://codigofonte.uol.com.br/noticias/att-quer-que-empresas-patrocinemtransferencia-de-dados-na- internet-movel>. Acesso em: 2 dez. 2015.

DE LUCA, C. O acesso gratuito a serviços internet no celular deve acabar?

Entenda o que está em jogo. Idgnow!, 6 set. 2014. Disponível em:

$<$ http://idgnow.com.br/blog/circuito/2014/09/06/o-acesso-gratuito-a-servicos-internetno-celular-deve-acabar/>. Acesso em: 2 dez. 2015.

DINHEIRO cibernético. Veja, 21 jun. 1995. Disponível em:

$<$ https://acervo.veja.abril.com.br/\#/edition/1397?page=96\&section=1\&word=internet \%20banking>. Acesso em: 2 dez. 2016. 
DINIZ, E. H. Cinco décadas de automação. GV Executivo, São Paulo, v. 3, n. 3, ago./out. 2004.

$\frac{}{29-50}$. Evolução do uso da Web pelos bancos. RAC, v. 4, n. 2, Maio/Ago. 2000:

; MEIRELLES, F.; FONSECA, C. E. C. Tecnologia bancária no Brasil: uma história de conquistas, uma visão de future. São Paulo: FGVRAE, 2010.

DIAS, L.C. Redes eletrônicas e novas dinâmicas do território brasileiro. In:

CASTRO, I. E.; GOMES, P. C. C. \& CORREAA, R. L. Brasil: questões atuais da reorganização do território. Rio de Janeiro, Bertrand Brasil, 1996. pp.115-144.

DO AMARAL, B. Acesso móvel patrocinado ganha forma como modelo de negócio. Mobiletime, 21 mai. 2014. Disponível em

<http://www.mobiletime.com.br/21/05/2014/acesso-movel-patrocinado-ganha-formacomo-modelo-de-negocio/378470/news.aspx>. Acesso em: 20 ago. 2015.

\section{. Claro junta Whatsapp, Facebook e Twitter em promoção de Zero}

Rating. Mobiletime, 15 jun. 2015a. Disponível em: < http://www.mobiletime.com.br/15/06/2015/claro-junta-whatsapp-facebook-e-twitterem-promocao-de-zero-rating/414167/news.aspx>. Acesso em: 27 out. 2015.

Decreto do Marco Civil trouxe insegurança jurídica, reclama diretor do Google. Convergecom, $1^{\circ}$ set. 2016a. Disponível em:

$<$ http://convergecom.com.br/teletime/01/09/2016/decreto-do-marco-civil-trouxeinseguranca-juridica-reclama-diretor-do-

google $/$ ?noticiario $=$ TL\&_akacao $=3673454 \& \_$_akcnt $=4 b 5767 d 4 \& \_$akvkey $=1964 \&$ utm_source=akna\&utm_medium=email\&utm_campaign=TELA+VIVA+News++02\%2F09\%2F2016+00\%3A09>. Acesso em: 2 dez. 2016.

. Novas regras de neutralidade de rede da FCC são publicadas nos EUA. Convergecom, 13 abr. 2015b. Disponível em:

$<$ http://convergecom.com.br/teletime/13/04/2015/novas-regras-de-neutralidade-derede-da-fcc-sao-publicadas-nos-eua/>. Acesso em: 2 dez. 2016.

. Operadoras apelam na justiça dos Estados Unidos para reverter regras de neutralidade. Convergecom, 29 jul. 2016b. Disponível em:

$<$ http://convergecom.com.br/teletime/29/07/2016/operadoras-apelam-na-justica-doseua-para-reverter-regras-de-neutralidade/>. Acesso em: 2 dez. 2016.

. Vivo dá internet de graça a usuário que assistir anúncio. Exame, 14 jun. 2016c. Disponível em: <http://exame.abril.com.br/marketing/vivo-da-internet-degraca-a-usuario-que-assistir-anuncio/> . Acesso em: 2 dez. 2016. 
E-BIT/BUSCAPÉ COMPANY. 33a edição Webshoppers. São Paulo, 2015.

Disponível em: <http://img.ebit.com.br/webshoppers/pdf/33_webshoppers.pdf >. Acesso em: 3 dez. 2016.

EDWARDS, P. N. The Closed World. Cambridge, MA, MIT Press, 1996.

ELTON, M. C. J.; CAREY, J. The prehistory of the Internet and its traces in the Present: implications for defining the field. In: DUTTON, William (Org.). The Oxford handbook of Internet Studies. Oxford: Oxford University Press, 2013.

EM MEIO à instabilidade no mercado, Bitcoin alcança maior valor em dois anos. Folha de S. Paulo, 16 jun. 2016. Disponível em:

$<$ http://www1.folha.uol.com.br/mercado/2016/06/1782418-em-meio-a-instabilidadeno-mercado-bitcoin-alcanca-maior-valor-em-2-anos.shtml>. Acesso em: 4 jan. 2017.

ENTENDA a curta história do Instagram, comprado pelo Facebook. G1, São Paulo, 10 abr. 2012. Disponível em:

<http://g1.globo.com/tecnologia/noticia/2012/04/entenda-curta-historia-do-instagramcomprado-pelo-facebook.html>. Acesso em: 4 jan. 2017.

EUA monitoraram telefonemas de 35 líderes mundiais, diz jornal. G1, São Paulo, 24 out. 2013. Disponível em: <http://g1.globo.com/mundo/noticia/2013/10/euamonitoram-telefonemas-de-35-lideres-mundiais-diz-jornal.html >. Acesso em: 4 jan. 2017.

FACEBOOK encerra compra do Instagram. G1, São Paulo, 6 set. 2012. Disponível em: <http://g1.globo.com/tecnologia/noticia/2012/09/facebook-encerra-compra-doinstagram.html>. Acesso em: 4 jan. 2017.

FACEBOOK anuncia crescimento dos lucros e do número de usuários. G1, 28 jan. 2016. Disponível em: <http://g1.globo.com/tecnologia/noticia/2016/01/facebookanuncia-crescimento-dos-lucros-e-do-numero-de-usuarios-

20160127211006500148.html>. Acesso em: 4 jan. 2017.

FARIELO, D. Marco Civil da Internet é regulamentado, mas desagrada operadoras. O Globo, 14 mai. 2016. Disponível em:

$<$ http://oglobo.globo.com/economia/marco-civil-da-internet-regulamentado-masdesagrada-operadoras-19304973>. Acesso em: 3 dez. 2016.

FEDERAÇÃO BRASILEIRA DE BANCOS. Pesquisa de Tecnologia Bancária 2015. São Paulo, 2015. Disponível em: <https://cmsportal.febraban.org.br/Arquivos/documentos/PDF/Relatorio\%20\%20Pesquisa\%20FEBRABAN\%20de\%20Tecnologia\%20Banc\%C3\%A1ria\%202015 .pdf>. Acesso em: 3 dez. 2016.

. Setor Bancário em Números, Tendências Tecnológicas e Agenda Atual 2012. São Paulo, 2012. Disponível em: <http://docplayer.com.br/667753-Ciab- 
febraban-2012-a-sociedade-conectada-setor-bancario-em-numeros-tendenciastecnologicas-e-agenda-atual.html>. Acesso em: 3 dez. 2016.

FERNANDES, M.; PADUAN, R. A Agência é o celular. Veja, 5 jul. 2000.

Disponível em:

<https://acervo.veja.abril.com.br/\#/edition/1656?page=126\&section=1\&word=automa \%C3\%A7\%C3\%A3o\%20banc\%C3\%A1ria>. Acesso em: $1^{\circ} \mathrm{dez} .2016$.

FERRARI, B. O facebook quer privatizar a internet e o Brasil pode ser um grande aliado. Época, 13 fev. 2016. Disponível em:

$<$ http://epoca.globo.com/vida/experiencias-digitais/noticia/2016/02/o-facebook-querprivatizar-internet-e-o-brasil-pode-ser-um-grande-aliado.html>. Acesso em: 3 dez. 2016.

FERRARI, P. Jornalismo Digital. São Paulo: Editora Contexto, 2014.

FERREIRA, R. A Sharp volta a sorrir. Istoé Dinheiro, cidade, 19 mar. 2015. Disponível em: <http://www.istoedinheiro.com.br/noticias/negocios/20150319/sharpvolta-sorrir/241495.shtml >. Acesso em: 27 out. 2016.

FLICHY, P. Les industries de l'imaginaire. Grenoble: P.U.G, 1980.

FONSECA, A. N; LOPES, L. Estudo comparativo sobre comércio eletrônico nas pequenas e médias empresas - no Brasil e na União Europeia. Ministério da Indústria, Comércio Exterior: Brasília, 2016. Disponível em:

$<$ http://pt.slideshare.net/mdicgovbr/estudo-comparativo-sobre-comrcio-eletrnico-naspequenas-e-mdias-empresas-no-brasil-e-unio-europeia>. Acesso em: 3 dez. 2016.

FREITAS, M. C. P. A internacionalização do sistema bancário brasileiro. Instituto de Pesquisa Econômica Aplicada: Brasília, 2011.

FRIEDLANDER, D.; GRINBAUM, R. Ajuda a banco custou R\$ 45 bi. Folha Online, [2000?]. Disponível em:

<http://www1.folha.uol.com.br/folha/dinheiro/banespa_governo.shtml>. Acesso em: 3 dez. 2016.

GARCIA, G. Facebook abre Internet.org para qualquer operadora de telefonia móvel. Info, São Paulo, 28 jul. 2015. Disponível em:

$<$ http://info.abril.com.br/noticias/internet/2015/07/facebook-abre-internet-org- paraqualquer-operadora-de-telefonia-movel.shtml>. Acesso em: 3 dez. 2015.

GARHAM, N. Capitalism and Communication: Global Culture and the Economics of Information. Londres: Sage.

GATES, B. A empresa na velocidade do pensamento: com um sistema nervoso digital. Tradução de Pedro Maia Soares, Gabriel Tranjan Neto. São Paulo: Companhia das Letras, 1999. 
GLOBO e Microsoft anunciam acordo estratégico e investimentos para desenvolver e implementar novos serviços de Internet no Brasil. Microsoft, 1999. Disponível em: <https://www.microsoft.com/brasil/pr/globocabe.htm>. Acesso em: 17 nov. 2016.

GOMES, H. S. Criado em 2009, Whatsapp cresceu mais rápido que Facebook em quatro anos. G1, São Paulo, 20 fev. 2014. Disponível em:

<http://g1.globo.com/tecnologia/noticia/2014/02/criado-em-2009-whatsapp-cresceumais-rapido-que-facebook-em-4-anos.html>. Acesso em: 4 jan. 2017.

GOOGLE encerra as vendas dos óculos Google Glass para consumidores. G1, São Paulo, 15 jan. 2015. Disponível em:

<http://g1.globo.com/tecnologia/noticia/2015/01/google-encerra-vendas-dos-oculosgoogle-glass-para-consumidores.html>. Acesso em: 4 jan. 2017.

GOULART, J. Banco Original, do grupo J\&F, chega ao varejo com operação 100\% digital. Estado de S. Paulo, 29 mar. 2016. Disponível em:

$<$ http://economia.estadao.com.br/noticias/negocios,banco-original--do-grupo-jef-chega-ao-varejo-com-operacao-100-digital,10000023620>. Acesso em: 4 dez. 2016.

GRADILONE, C. A maioridade do Proer. Istoé Dinheiro, [2013?]. Disponível em: $<$ http://www.istoedinheiro.com.br/noticias/financas/20131108/maioridadeproer/5347>. Acesso em: 4 dez. 2016.

GREENWALD, G.; MACASKILL, E. NSA Prism program taps in to user data of Apple, Google and others. The Guardian, 7 jun. 2013. Disponível em:

<https://www.theguardian.com/world/2013/jun/06/us-tech-giants-nsa-data>. Acesso em: 4 dez. 2016.

GREENWALD, G. XKeyscore: NSA tool collect's 'nearly everything a user does on the internet'. The Guardian, 31 jul. 2013. Disponível em:

$<$ https://www.theguardian.com/world/2013/jul/31/nsa-top-secret-program-onlinedata>. Acesso em: 5 fev. 2017.

GROMOV, G. R. History of Internet and WWW - The Roads and Crossroads of Internet History. Netvalley, 1997.

HAFNER, K. L. M. Where wizards stay up late: the origins of the Internet. New York, Simon \& Schuster, 1996.

HAMMAN, R. Google Glass: saiba tudo sobre os óculos da Google. Tecmundo, 27 jun. 2012. Disponível em: <https://www.tecmundo.com.br/project-glass/25785google-glass-saiba-tudo-sobre-os-oculos-da-google.htm>. Acesso em: 4 jan. 2017.

HERSCOVICI, A. Contribuições e limites das analyses da escolar francesa, à luz do estudo da economia digital - uma releitura do debate dos anos 80. Revista de 
Economia Politica de las Tecnologias de la Información y Comunicación, v. xi, n. 1, ene./abr. 2009.

HINDMAN, M. The Myth of digital democracy. New Jersey: Princeton. University Press, 2009.

HUET, A.; ION, J.;; LEFEBVRE, A.; MIÈGE, B.; PERON, R. Capitalisme et industries culturelles. Grenoble: P.U.G, 1978.

IAMONTI, V. Automação Bancária e o Circuito Espacial das Tecnologias

Bancárias - Sucessões e coexistências nas Dinâmicas da formação socioespacial brasileira. In: VII Congresso Brasileiro de geógrafos, 2014, Vitória. Disponível em: <http://www.cbg2014.agb.org.br/resources/anais/1/1404689121_ARQUIVO_Victor_ Iamonti_Trabalho_Completo.pdf>.Acesso em: 4 dez. 2016.

IGREJA também dará acesso grátis. Info Online, 14 jan. 2000. Disponível em: <https://www.nic.br/noticia/na-midia/igreja-catolica-tambem-dara-acesso-gratis/>. Acesso em: 4 dez. 2016.

INTERNATIONAL MONETARY FUND. Financial Integration in Latin America. Washington, 2016. Disponível em:

<https://www.imf.org/external/np/pp/eng/2016/030416.pdf >. Acesso em: 4 dez. 2016.

INTERNATIONAL TELECOMMUNICATION UNION. ICT Facts \& Figures 2015. Geneva, 2015. Disponível em: <https://www.itu.int/en/ITU-

D/Statistics/Documents/facts/ICTFactsFigures2015.pdf >. Acesso em: 4 dez. 2016.

INTERNET tem mais um acesso gratuito. Folha de S. Paulo, São Paulo, 11 jan. 2000. Disponível em:

<http://www1.folha.uol.com.br/fsp/dinheiro/fi1101200021.htm>. Acesso em: 4 dez. 2016.

INTERNET gratuita fracassa nos EUA e no Canadá. UOL, 31 jan. 2003. Disponível em: <http://noticias.uol.com.br/mundodigital/ultimas/ult1345u28.jhtm>. Acesso em: 20 jun. 2015.

ISAACSON, W. Os inovadores: uma biografia da revolução digital. São Paulo: Companhia das Letras, 2014.

ITAÚ e Unibanco anunciam fusão e criam maior banco do hemisfério sul. UOL, São Paulo, 3 nov. 2008. Disponível em:

<http://economia.uol.com.br/ultnot/2008/11/03/ult4294u1817.jhtm>. Acesso em: 27 out. 2016. 
JUNQUEIRA, D. Evan Spiegel, criador do Snapchat, explica motivo do "não" aos US\$ 3 bilhões do Facebook. UOL, 8 jan. 2014. Disponível em:

<http://gizmodo.uol.com.br/snapchat-facebook/>. Acesso em: 2 dez. 2014

KING, I.; SCIAUDONE, C. Here's how Brazil is giving every Citizen Free Mobile Data. Bloomberg, 18 ago. 2015. Disponível em:

<http://www.bloomberg.com/news/articles/2015-08-18/here-s-how-brazil-is-givingevery-citizen-free-mobile-data>. Acesso em: 3 dez. 2016.

KLEINA, M. Qual foi o primeiro celular do mundo com internet?. Tecmundo, 2 set. 2015. Disponível em: <https://www.tecmundo.com.br/celular/85491-primeirocelular-mundo-internet-video.htm>. Acesso em: 4 dez. 2016.

KNIGHT, P. T. A internet no Brasil - origens, estratégias, desenvolvimento e governaça. Author House: Bloomington, 2014.

KURBALIJA, J. An introduction to Internet Governance. DiploFoundation: Genebra, 2008.

LEFÈVRE, F. Zero Rating, planos de serviço limitados e o direito de acesso à Internet. Politc, Rio de Janeiro, $\mathrm{n}^{\mathrm{o}}$ 21, Ago. 2015. Disponível em: < https://www.politics.org.br/edicoes/zero-rating-planos-de-servi\%C3\%A7o-limitadose-o-direito-de-acesso-\%C3\%A0-internet >. Acesso em: 19 out. 2015.

LEINER, B. M. et al. Brief History of the Internet. Internet Society, [2003-2016?]. Disponível em: <http://www.internetsociety.org/internet/what-internet/historyinternet/brief-history-internet>. Acesso em: 3 dez. 2016.

LEWIN, K. Frontiers in Group Dynamics. II. Channels of Group Life: Social Planning and Action Reserach, Human Relations, vol. 1, n.2, p. 143-153, 1947.

LOBATO, E. Telecom Itália admite sair da Globo.com. Folha de S. Paulo, Milão, 15 fev. 2002. Disponível em:

<http://www1.folha.uol.com.br/fsp/dinheiro/fi1502200223.htm>. Acesso em: 4 jan. 2017.

LOPES, R. S. Informação, conhecimento e valor. São Paulo: Radical Livros, 2008a.

Por uma Comunicação popular e alternativa no contexto da EPC. In: BOLAÑO, C. (Org.). Comunicação e a crítica da economia política: perspectivas teóricas e epistemológicas. São Cristóvão: Editora UFS, 2008 b.

; SIMIS, A. Economia Política da Comunicação. In: Panorama da Comunicação e das telecomunicações no Brasil. Brasília: Ipea, 2010. 
LUCERO, E. Governança da Internet: aspectos da formação de um regime global de oportunidades para a ação diplomática. Brasília: Fundação Alexandre de Gusmão, 2011.

MACASKILL, E. et al. GCHQ taps fibre-optic cables for secret access to world's communications. The Guardian, 21 jun. 2013. Disponível em:

$<$ https://www.theguardian.com/uk/2013/jun/21/gchq-cables-secret-worldcommunications-nsa>. Acesso em: 3 set. 2016.

MACEDO, A. Na crise global de 2008, fusão de Itaú e Unibanco cria $4^{\text {a }}$ maior empresa da AL. O Globo, 10 nov. 2015. Disponível em

<http://acervo.oglobo.globo.com/em-destaque/na-crise-global-de-2008-fusao-de-itauunibanco-cria-4-maior-empresa-da-al-18010648 >. Acesso em: 27 out. 2017.

MARCEL, D. Exclusivo: Tem internet grátis na praça. Istoé Dinheiro, 7 mar. 2014. Disponível em: < http://www.istoedinheiro.com.br/noticias/mercadodigital/20140307/exclusivo-tem-internet-gratis-praca/9460.shtml > . Acesso em: 20 jun. 2015.

MARCELINO, F. Saída do HSBC mostra redução de bancos estrangeiros. Exame, 12 jul. 2015. Disponível em: < http://exame.abril.com.br/negocios/hsbc-se-une-acitigroup-no-cemiterio-de-bancos-estrangeiros/>. Acesso em: 27 out. 2016.

MARQUES, I. Reserva de mercado: um mal entendido caso político-tecnológico de "sucesso" democrático e "fracasso" autoritário. Revista de Economia UFPR, Curitiba, n. 24, p. $89-114,2000$.

MARSDEN, C. Comparative case studies in implementing Net Neutrality: a critical analysis. Paper apresentado em "TPRC 43: The 43rd Research Conference on Communication, Information and Internet Policy". Arlington, 2015a.

. Zero Rating and mobile Net Neutrality. In: BELI, Lucas; DE FILIPPI, Primavera (Orgs.). Net Neutrality Compedium, human rights, free competition and the future of the internet. Suíça: Springer, 2015b, p. 241 a 260.

MATTELART, A. História da sociedade da informação. São Paulo: Loyola, 2002.

História da sociedade da informação. São Paulo: Loyola, 2006.

MÁXIMO, W. Bancos começam a usar interligencia artificial no relacionamento com clientes. Agência Brasil, 26 jun. 2016. Disponível em:

<http://agenciabrasil.ebc.com.br/economia/noticia/2016-06/bancos-comecam-usarinteligencia-artificial-no-relacionamento-com-clientes >. Acesso em: 4 jun. 2016.

MAZUI, G.; BULBLITZ, J.; CALDAS, C. Banrisul está na mesa de negociação, diz Meirelles sobre socorro do governo federal ao RS. Zero Hora, 26 jan. 2017.

Disponível em: <zh.clicrbs.com.br/rs/noticias/politica/noticia/2017/01/banrisul-estara- 
na-mesa-de-negociacao-diz-meirelles-sobre-socorro-do-governo-federal-ao-rs9614018.html>. Acesso em: 28 jan. 2017.

McCHESNEY, R. W. Digital Disconnect. New York: The New Press, 2013.

MEDEIROS, H. Novo 0800 de dados dará internet grátis em sites e serviços.

Terra, 16 out. 2014. Disponível em: <http://tecnologia.terra.com.br/novo-0800-dedados-dara-internet-gratis-em-sites-eservicos,236747088ba19410VgnVCM10000098cceb0aRCRD.html>. Acesso em: 23 jan. 2016.

MELO, J. M; Economia Política da Comunicação no Brasil de 1923-2008 Precursores, pioneiros, baluartes e vanguardistas. Intercom - Revista Brasileira de Ciências da Comunicação , São Paulo, v.32, n.1, p. 15-31, jan./jun. 2009.

; MELO, P. B. (Orgs.). A economia política da Comunicação:

vanguardismo nordestino. Recife: Fundaj, 2012.

MENCONI, D.; NETO, J. S. O banco virtual. Veja, 9 ago. 1995. Disponível em: $<$ https://acervo.veja.abril.com.br/\#/edition/33133?page=60\&section=1>. Acesso em: 3 dez. 2016.

MIÈGE, B.; PAJON, P.; SALAUN, J. L'industrialisation de l'audiovisuel. Paris: Res Babel, 1986.

MINISTÉRIO DA CIENCIA E TECNOLOGIA. A Sociedade da Informação no Brasil - Livro verde. Brasília, DF, 2000.

MONTEIRO, T. Dilma cancela viagem aos EUA. Estado de S. Paulo, 17 set. 2013. Disponível em: <>. Acesso em: 5 fev. 2017.

MORAES, M. Pioneiro na informatização, Itaú cultiva imagem de banco inovador e moderno. Folha de S. Paulo, 4 nov. 2008. Disponível em: <http://www1.folha.uol.com.br/fsp/dinheiro/fi0411200824.htm >. Acesso em: 27 out. 2016.

MOSCO, V. Economia Política da Comunicação: uma perspectiva laboral. Cadernos do Noroeste, Série Comunicação, vol. 12, 1999. Disponível em: < http://www.lasics.uminho.pt/ojs/index.php/comsoc/article/view/1440/1370 >. Acesso em: 15 jan. 2016.

La Economia Política de la Comunicación: una actualización diez años después. CIC Cuadernos de Información e Comunicación, Madrid, v.11, 2006. Disponível em: <http://revistas.ucm.es/index.php/CIYC/article/view/8118> Acesso em: 30 mai. 2015. 
. The Digital Sublime: myth, power and cyberspace. Cambrigde: The MIT Press, 2004.

. The Political Economy of Communication. $2^{\text {a }}$ Edição. Londres: SAGE, 2009.

MURDOCK, G., GOLDING, P. For a political economy of mass communication. In: P. GOLDING, G. MURDOCK, The political economy of media. Vol. 1.

Cheltenham, The International Library of Studies in Media and Culture.

NAKANE, M. A Test of Competition in Brazilian Banking. Banco Central do Brasil, Working Paper Series n. 12, 2001.

NÃO há almoço nem Internet grátis, diz especialista. UOL, 19 dez. 2002. Disponível em: 〈http://noticias.uol.com.br/mundodigital/ultimas/ult1345u4.jhtm>. Acesso em: 21 set. 2015.

NA primavera árabe internet é faca de dois gumes. Exame.com, 13 mai. 2011. Disponível em: < http://exame.abril.com.br/tecnologia/na-primavera-arabe-internet-efaca-de-dois-gumes/>. Acesso em: 4 jan. 2017.

NET neutrality enshrined in Dutch law. The Guardian, 23 jun. 2011. Disponível em: <https://www.theguardian.com/technology/2011/jun/23/netherlands-enshrines-netneutrality-law>. Acesso em: 4 dez. 2016.

NEW Solar System Internet Technology Debuts on the International Space Station. Nasa, 21 jun. 2016. Disponível em: <https://www.nasa.gov/feature/new-solar-systeminternet-technology-debuts-on-the-international-space-station>. Acesso em: 3 dez. 2016.

NOGUEIRA, P. Cibernética bancária. Veja, 22 dez. 1982. Disponível em: $<$ https://acervo.veja.abril.com.br/\#/edition/33803? page=116\&section=1>. Acesso em: 3 dez. 2016.

NOGUEIRA, C.; VARGAS, N. A radiografia da internet brasileira. Veja, 25 out. 2000. Disponível em: <http://docplayer.com.br/16220814-A-radiografia-da-internetbrasileira.html>. Acesso em: 4 dez. 2016.

O PRIMEIRO choque do petróleo em 1973. Folha Online, [2000?]. Disponível em: <http://www1.folha.uol.com.br/folha/dinheiro/petroleo_choque1.shtml>. Acesso em: 2 dez. 2016.

PADUAN, R. O banco lá de casa. Veja, dez. 1999. Disponível em: < https://acervo.veja.abril.com.br/\#/edition/1628A?page=60\&section=1\&word=Securit y\%20First\%20Network\%20Bank>. Acesso em: 3 dez. 2016. 
PAIVA, F. Banco do Brasil fará campanha na TV para promover app de pagamento por NFC. Mobiletime, 15 set. 2016a. Disponível em:

<http://www.mobiletime.com.br/15/09/2016/banco-do-brasil-fara-campanha-na-tvpara-promover-app-de-pagamento-por-

nfc/456224/news.aspx?_akacao $=3696475 \& \_a k c n t=4 b 5767 d 4 \&$ _akvkey $=3 e d e \& u t$ m_source=akna\&utm_medium $=$ email\&utm_campaign=MOBILE+TIME+News++15\%2F09\%2F2016+19\%3A22>. Acesso em: 3 dez. 2016.

Banco do Brasil terá conta simplicada aberta pelo celular. Mobiletime, 23 jun. 2016b. Disponível em: <http://www.mobiletime.com.br/23/06/2016/banco-dobrasil-tera-conta-simplificada-com-abertura-pelo-

celular $/ 442862 /$ news.aspx ?_akacao $=3393317 \&$ _akcnt $=4 \mathrm{~b} 5767 \mathrm{~d} 4 \&$ \&_akvkey $=\mathrm{f} 941$ \&utm_source=akna\&utm_medium $=$ email\&utm_campaign=MOBILE+TIME+News+ $-+23 \% 2 \mathrm{~F} 06 \% 2 \mathrm{~F} 2016+21 \% 3 \mathrm{~A} 20>$. Acesso em: 3 dez. 2016.

Bancos não se sentem ameaçados pela chegada de tecnologias móveis e Iot. Mobiletime, 22 jun. 2016c. Disponível em:

<http://www.mobiletime.com.br/22/06/2016/bancos-nao-se-sentem-ameacados-pelachegada-de-tecnologias-moveis-e-

iot $/ 442722 /$ news.aspx? _akacao $=3389271 \&$ _akcnt $=4 \mathrm{~b} 5767 \mathrm{~d} 4 \&$ _akvkey $=6 \mathrm{a} 05 \&$ ut m_source=akna\&utm_medium=email\&utm_campaign=MOBILE+TIME+News++23\%2F06\%2F2016+02\%3A07>. Acesso em: 3 dez. 2016.

. Bradesco inaugura a era da Internet Patrocinada. Mobiletime, 13 mar. 2014a. Disponível em <http://www.mobiletime.com.br/13/03/2014/bradescoinaugura-a-era-da-internet-movel-patrocinada/371322/news.aspx >. Acesso em: 21 ago. 2015.

. Bueiros conectados e ouvidos em postes são instalados no Rio.

Mobiletime, 6 de jul. 2016d. Disponível em:

<http://www.mobiletime.com.br/07/07/2016/bueiros-conectados-e-ouvidos-empostes-sao-instalados-no-

rio/444762/news.aspx?_akacao $=3444788 \& \_a k c n t=4 b 5767 \mathrm{~d} 4 \& \&$ _akvkey $=4 \mathrm{f} 1 \mathrm{~b} \& u t$ m_source=akna\&utm_medium $=$ email\&utm_campaign=MOBILE+TIME+News++07\%2F07\%2F2016+02\%3A07>. Acesso em: 4 dez. 2016.

. Há 14,9 milhões de contas de dinheiro móvel na América Latina.

Mobiletime, 13 mai. 2015a. Disponível em:

$<$ http://www.mobiletime.com.br/13/05/2015/ha-14-9-milhoes-de-contas-de-dinheiromovel-na-america-latina/411723/news.aspx>. Acesso em: 3 dez. 2016.

Internet móvel patrocinada vai virar produto de prateleira na Vivo.

Convergecom, 18 mar. 2014b. Disponível em:

<http://convergecom.com.br/teletime/18/03/2014/internet-movel-patrocinada-vaivirar-produto-de-prateleira-na-vivo/> . Acesso em: 22 ago. 2014. 
Modelo brasileiro de Internet Móvel gratuita deve ser exportado, prevê Qualcomm. Teletime, 16 set. 2014c. Disponível em:

$<$ http://convergecom.com.br/teletime/16/09/2014/modelo-brasileiro-de-internetmovel-gratuita-deve-ser-exportado-preve-qualcomm/> Acesso em: 20 ago. 2015

. Privalia adota tráfego patrocinado em seu app no Brasil. Mobiletime, 2 ago. 2016e. Disponível em: <http://www.mobiletime.com.br/02/08/2016/privaliaadota-trafego-patrocinado-em-seu-app-no-brasil/451482/news.aspx $>$. Acesso em: 3 dez. 2016.

. Rio vai monitorar fluxos de pessoas via wi-fi no Porto Maravilha. Mobiletime, 6 jul. 2016f. Disponível em: $<$ http://www.mobiletime.com.br/06/07/2016/cidades-inteligentes-rio-vai-monitorarfluxo-de-pessoas-via-wi-fi-no-portomaravilha/444642/news.aspx $?$ noticiario $=T T \& \_a k a c a o=3444637 \&$ _akcnt $=4 \mathrm{~b} 5767 \mathrm{~d}$ $4 \& \_$_akvkey $=7 \mathrm{e} 00 \& u t m \_s o u r c e=a k n a \& u t m \_$medium $=$email\&utm_campaign=TELE TIME+News+-+07\%2F07\%2F2016+01\%3A02>. Acesso em: 3 dez. 2016.

PANTOJA, S.; FERREIRA, R. Evolução da Internet no Brasil e no mundo. Ministério da Ciência e Tecnologia / Secretária de Política de Informática e Automação: Brasília, DF, 2000. Disponível em:

<ftp://ftp.mct.gov.br/Biblioteca/1750-Evolucao_internet_Brasil_mundo.pdf > . Acesso em: 4 dez. 2016.

PARANÁ, E. A finança digitalizada - capitalismo financeiro e revolução informacional. Florianópolis: Insular, 2016.

PERRIN, F. Startups financeiras são um desfio para bancos, diz presidente do Itaú. Folha de S. Paulo, 21 jun. 2016. Disponível em: <http://www1.folha.uol.com.br/mercado/2016/06/1783944-start-ups-financeiras-saoum-desafio-para-bancos-diz-presidente-do-itau.shtml>. Acesso em: 22 out. 2016.

PERCURSOR francês da internet, Minitel saíra do ar no sábado. UOL, 29 jun. 2012. Disponível em: <http://olhardigital.uol.com.br/noticia/precursor-frances-da-internet,minitel-saira-do-ar-no-sabado/27457>. Acesso em: 2 dez. 2016.

PEW RESEARCH CENTER. Internet use over time. Washington, 2000. Disponível em: <http://www.pewinternet.org/data-trend/internet-use/internet-useover-time/>. Acesso em: 4 dez. 2016.

Online Banking 2002. Washington, 2002. Disponível em:

<http://www.pewinternet.org/2002/11/17/online-banking-2002/>. Acesso em: 4 dez. 2016.

. Online Banking 2005. Washington, 2005. Disponível em:

<http://www.pewinternet.org/2005/02/09/online-banking-2005/>. Acesso em: 4 dez. 2016. 
. Online Banking 2006. Washington, 2006. Disponível em:

<http://www.pewinternet.org/2006/06/14/online-banking-2006/>. Acesso em: 4 dez. 2016.

PIMENTEL, J. P. Caixa eletrônico faz 40 anos. Gazeta do Povo, Curitiba, 26 jun. 2007. Disponível em: < http://www.gazetadopovo.com.br/tecnologia/caixaeletronico-faz-40-anos-aiwkw248ujv2421mvdzen9xzi >. Acesso em: 27 out. 2016

PIRES, H. F. Reestruturação Inovativa e Reorganização das Instituições Financeiras do Setor Privado no Brasil. Geouerj No2, Rio de Janeiro, p. 65-79, 1997.

PITA, M. Internet paga por dono de conteúdo estreia no Brasil. Telesíntese, 13 mar. 2014. Disponível em: <http://www.telesintese.com.br/internet-paga-por-donode-conteudo-estreia-no-brasil/> . Acesso em: 20 ago. 2015.

. Decreto que regulamenta Marco Civil é essencial para garantir direitos. Carta Capital, 31 mai. 2016. Disponível em:

<http://www.cartacapital.com.br/blogs/intervozes/decreto-que-regulamenta-o-marcocivil-e-essencial-para-garantir-direitos>. Acesso em: 4 dez. 2016.

PHAN, D.; N'GUYEN, G. Economie des télécommunications et de l'internet. Paris, 1999.

POLONI, G. O náufrago e a net. Veja, 24 out. 2001. Disponível em: <https://acervo.veja.abril.com.br/\#/edition/1723?page=98\&section=1\&word=INTER NET\%20BANKING>. Acesso em: 4 dez. 2016.

POR trás do acesso gratuito. Estado de Minas Gerais, 7 fev. 2000. Disponível em: <https://www.nic.br/noticia/na-midia/por-tras-do-acesso-gratuito/>. Acesso em: 3 dez. 2016.

POSSEBON, S. Kassab diz que vai estudar mudanças no decreto do Marco Civil. Convergecom, 18 out. 2016. Disponível em:

<http://convergecom.com.br/teletime/18/10/2016/kassab-disse-que-vai-estudarmudancas-no-decreto-do-marco-civil/>. Acesso em: 3 dez. 2016.

PREÇO final da compra do Whatsapp pelo Facebook sobe para US\$ 22 bi. Folha de S. Paulo, 7 out. 2014. Disponível em: <http://www1.folha.uol.com.br/tec/2014/10/1528643-preco-final-da-compra-dowhatsapp-pelo-facebook-sobe-para-us-22-bi.shtml>. Acesso em: 4 jan. 2017.

PRESCOTT, R. Duas décadas que mudaram o Brasil. Revista Abranet, ano IV, edição 12, mar. 2015. Dsiponível em:

<http://issuu.com/convergenciadigital/docs/abranet12 >. Acesso em: 4 dez. 2016. 
PRIVALIA oferece navegação gratuita. Privalia pressroom, 9 ago. 2016. Disponível em: <http://pressroom.privalia.com/brazil/privalia-na-midia/privalia-oferecenavegacao-gratuita/>. Acesso em: 16 nov. 2016.

PROCESSO de impeachment é aberto e Dilma é afastada por até 180 dias. G1, Brasília, 12 mai. 2016. Disponível em: <http://g1.globo.com/politica/processo-deimpeachment-de-dilma/noticia/2016/05/processo-de-impeachment-e-aberto-e-dilmae-afastada-por-ate-180-dias.html>. Acesso em: 3 dez. 2016.

PROJETO de internet gratuita do Facebook é criticado na América Latina. Carta Capital, 23 jun. 2015. Disponível em:

$<$ http://www.cartacapital.com.br/tecnologia/projeto-de-internet-gratuita-do-facebooke-criticado-na-america-latina-4420.html >. Acesso em: 20 jan. 2015.

RAMOS, M. Uma nova legislação para as comunicações brasileiras e o paradoxo da radiodifusão. Tendências XXI, II(2), p. 176-182. Lisboa.

RAMOS, P. H. S. Arquitetura da rede e regulação: a neutralidade da rede no Brasil. 2015. 218 f. Dissertação (Mestrado em Direito) - Escola de Direito de São Paulo, Fundação Getúlio Vargas, São Paulo, 2015a.

Zero Rating: uma introdução ao debate. Politc, Rio de Janeiro, $\mathrm{n}^{\circ}$ 21, Ago. 2015b. Disponível em: < https://www.politics.org.br/edicoes/zero-rating-umaintrodu\%C3\%A7\%C3\%A3o-ao-debate >. Acesso em: 19 out. 2015.

RECUERO, R. Redes Sociais na Internet, Difusão de Informação e Jornalismo: elementos para discussão. In: SOSTER, D. A.; FIRMINO, F. (Orgs.). Metamorfoses jornalísticas 2: a reconfiguração da forma. Santa Cruz do Sul: UNISC, 2009, v. , p. 1269.

REDE NACIONAL DE ENSINO E PESQUISA. A história por trás dos 20 anos da internet comercial no Brasil. Brasília, 2015. Disponível em $<$ https://www.rnp.br/destaques/historia-por-tras-20-anos-internet-comercial-brasil >. Acesso em: 2 dez. 2016.

Guia do Empreendedor Internet/Brasil. Brasília, 1996. Disponível em: <http://www.cgi.br/media/docs/publicacoes/4/guia-rnp.pdf >. Acesso em: 30 nov. 2016.

RIZÉRIO, L. Há treze anos, bolha da internet começava a explodir nos EUA. Infomoney, São Paulo, 12 mar. 2013. Disponível em:

$<$ http://www.infomoney.com.br/mercados/acoes-e-indices/noticia/2698151/anosbolha-internet-comecava-explodir-nos-eua-veja-como-foi>. Acesso em: 19 jun. 2015.

SACONI, R. Há 30 anos, o primeiro caixa eletrônico no Brasil. Estado de S. Paulo, 12 abr. 2013. Disponível em: <http://acervo.estadao.com.br/noticias/acervo,ha-30anos-o-primeiro-caixa-eletronico-no-brasil,8995,0.htm>. Acesso em: 27 out. 2016. 
SALOMÃO, K. Pavel Durov, o polêmico fundador do aplicativo Telegram.

Exame.com, 20 dez. 2015. Disponível em: <http://exame.abril.com.br/negocios/paveldurov-o-polemico-fundador-do-aplicativo-telegram/>. Acesso em: 4 jan. 2017.

SANTAELLA, L. Comunicação e pesquisa: projetos para mestrado e doutorado. São Paulo: Hacker Editores, 2001.

SANTARÉM, P. R. D. S. O Direito achado na Rede - a emergência do acesso à internet como direito fundamental no Brasil. 2010. 158 f. Dissertação (Mestrado em Direito, Estado e Constituição) - Programa de Pós-graduação em Direito, Universidade de Brasília, Brasília, 2010.

SANTOS, M. E. R. D. Ajustamento estratégico do setor bancário brasileiro ao Plano Real. 2004. 107 f. Dissertação (Mestrado em Economia) - Programa de PósGraduação em Economia, CAEN, Universidade Federal do Ceará, Fortaleza, 2004.

SARTI, I. Comunicação e dependência cultural: um equívoco. In: WERTHEIN, J (Org.). Meios de Comunicação: realidade e mito. São Paulo: Nacional, 1979.

SCHILLER, D. A globalização e as novas tecnologias. Lisboa: Editorial Presença, 2002.

. Amazon, Apple, Google: as gigantes pós-crise. Le Monde Diplomatique, 3 dez. 2009. Disponível em: < http://www.diplomatique.org.br/artigo.php?id=526>. Acesso em: 21 set. 2015.

A ressaca mundial. Le Monde Diplomatique, $1^{\circ}$ jul. 2003. Disponível em: <http://www.diplomatique.org.br/acervo.php?id=776>. Acesso em: 21/09/2015.

Geopolítica da espionagem. Le Monde Diplomatique, 5 nov. 2014.

Disponível em: < http://www.diplomatique.org.br/artigo.php?id=1762>. Acesso em: 21 set. 2015.

. Power under Pressure: Digital Capitalism in crisis. International Journal of Communication. Califórnia, 2011, v. 5. Disponível em:

<http://ijoc.org/index.php/ijoc/article/view/1226>. Acesso em: 27 mai. 2015.

Quem governará a internet?. Le Monde Diplomatique, $1^{\circ}$ fev. 2013. Disponível em: < http://www.diplomatique.org.br/artigo.php?id=1367>. Acesso em: 21 set. 2015.

SCHILLER, H. I. O império norte-americano das comunicações. Petrópolis: Vozes, 1976. 
SCHOFIELD, H. Minitel: The rise and fall of the France-wide web. BBC News, Paris, 28 jun. 2012. Disponível em: <http://www.bbc.com/news/magazine18610692>. Acesso em: 4 dez. 2016.

SENADO cassa mandato de Dilma; Congresso dará posse efetiva a Temer. Folha de S. Paulo, 31 ago. 2016. Disponível em: <http://www1.folha.uol.com.br/poder/2016/08/1808784-senado-cassa-mandato-dedilma-congresso-dara-posse-efetiva-a-temer.shtml>. Acesso em: 4 dez. 2016.

SERVIÇO de web gratuita do Facebook é banido da Índia e gera polêmica em outros países. Associação Nacional de Jornais, 11 fev. 2016. Disponível em:

<http://www.anj.org.br/2016/02/11/servico-de-web-gratuita-do-facebook-e-banidoda-india-e-gera-polemica-em-outros-paises/> . Acesso em: 4 dez. 2016.

SILVA, S. P. Internet em redes de alta velocidade: concepções e fundamentos sobre banda larga. In: SILVA, S. P; BIONDI, A. Caminhos para universalização da internet banda larga: experiência internacional e desafios brasileiros. São Paulo: Intervozes, 2012. P. 23 a 50.

SMANIOTTO, E. N.; ALVES, T. W. Concentração e poder de mercado no sistema bancário brasileiro: uma análise pós-Plano Real. Perspectiva econômica, São Leopoldo, p. 29-41, v. 12, n.1, 2016.

SMYTHE, D. W (1977). Las comunicaciones: agujero negro del marxismo occidental, in Richeri, G. (1983).

STRIPOLI, G. Zuum, m-wallet da Vivo e da Mastercard, espera conquistar 200 mil clientes esse ano. Mobile Time, 14 mai. 2013. Disponível em:

<http://www.mobiletime.com.br/14/05/2013/zuum-m-wallet-da-vivo-e-damastercard-espera-conquistar-200-mil-clientes-este-ano/340438/news.aspx >. Acesso em: 4 dez. 2016.

SUTEL, S. AOL buys Time Warner for \$162 billion. ABC News, 10 jan. 2000.

Disponível em: <http://abcnews.go.com/Business/Decade/aol-buys-time-warner-162billion/story?id=9279138>. Acesso em: 4. dez 2016.

TAPIA, J. R. B. A trajetória da política de informática brasileira. São Paulo, Papirus, 1995.

TCU fiscaliza acompanhamento da Anatel sobre bens reversíveis nas concessões de telefonia móvel. Tribunal de Contas da União, 20 jul. 2016. Disponível em:

$<$ http://portal.tcu.gov.br/imprensa/noticias/tcu-fiscaliza-acompanhamento-da-anatelsobre-bens-reversiveis-nas-concessoes-de-telefonia-fixa.htm >. Acesso em: 4 fev. 2017. 
TELECOM Itália compra 30\% da Globo.com. Estado de S. Paulo, $1^{\circ}$ jun. 2000. Disponível em: <http://www.estadao.com.br/noticias/geral,telecom-italia-compra-30da-globocom,20000601p12348>. Acesso em: 4 jan. 2017.

TELECOMUNICAÇÕES BRASILEIRAS. Relatório Telebras 1987. Brasília, DF, 1987. Disponível em: <http://www.telebras.com.br/inst/wpcontent/uploads/2011/03/RA1987.pdf>. Acesso em: 4 dez. 2016.

TIGRE, P. B. As multinacionais da informática no Brasil. RAP - Revista de Administração Pública, Rio de Janeiro, p. 43-56, v. 15, n.1, 1981.

TREMBLAY, G. La théorie des industries culturelles face aux progrès de la numerisation. Sciences de la société 40, 1997.

TWITTER rejeitou em 2008 uma oferta milionária de compra do Facebook. Exame, Nova York, 3 jan. 2011. Disponível em: <http://exame.abril.com.br/negocios/twitterrejeitou-em-2008-uma-oferta-milionaria-de-compra-do-facebook/>. Acesso em: 4 dez. 2016.

UM ANO de internet.org. Facebook Newsroom, 27 jul. 2015. Disponível em: <http://br.newsroom.fb.com/news/2015/07/um-ano-de-internet-org/>. Acesso em: 4 de dez. 2016.

UNIÓN LATINA DE ECONOMIA POLÍTICA DE LA INFORMACIÓN, LA COMUNICACIÍN Y LA CULTURA. Carta de Buenos Aires. Buenos Aires, 2001. Disponível em: <http://www.ulepicc.es/web/carta.htm>. Acesso em: 4 dez. 2016.

VALENTE, G. CMN permite abertura de conta corrente e poupança pela internet. O Globo, Brasília, 25 abr. 2016. Disponível em:

$<$ http://oglobo.globo.com/economia/cmn-permite-abertura-de-conta-correntepoupanca-pela-internet-19158112>. Acesso em: 4 dez. 2016.

VIEIRA, E. Os bastidores da Internet no Brasil - As histórias de sucesso e de fracasso que marcam a Web brasileira. Barueri: Manole, 2003.

VIVENDI confirma compra do Seagram por US\$ 34 bi. Folha de S. Paulo, São Paulo, 20 jun. 2000. Disponível em:

<http://www1.folha.uol.com.br/folha/dinheiro/ult91u488.shtml>. Acesso em: 27 out. 2016.

VIVENDI, Seagram e Canal Plus formam gigante no setor de mídia. UOL, 20 jun. 2000. Disponível em:

<http://noticias.uol.com.br/economia/ultnot/2000/06/20/ult29u1160.jhtm >. Acesso em: 27 out. 2016. 
VERIZON compra AOL por US\$ 4,4 bilhões. UOL Economia, 12 mai. 2015.

Disponível em: <http://economia.uol.com.br/noticias/afp/2015/05/12/verizon-compraaol-por-us-44-bilhoes.htm>. Acesso em: 4 jan. 2017.

VERIZON anuncia a compra do Yahoo por US\$ 4,83 bilhões. G1, São Paulo, 25 jul. 2016. Disponível em: <http://g1.globo.com/tecnologia/noticia/2016/07/verizonanuncia-compra-do-yahoo.html>. Acesso em: 4 jan. 2017.

WU, T. Why have a Telecommunications Law-Anti-Discrimination Norms in Communication. J. on Telecomm. \& High Tech. L., v. 5, p. 15, 2006.

. Impérios da Comunicação - Do telefone à internet, da AT\&T ao Google. Rio de Janeiro: Zahar, 2012.

WILLIAMS, R. Televisione - Tecnologia e forma culturale. Milão: Editori Riuniti, 1974.

YATES, S. Ascensão e queda do provimento de acesso gratuito à internet no Brasil: o papel do modelo de negócios. Rio de Janeiro: Fundação Getúlio Vargas, 2012.

\section{LEGISLAÇÃ̃}

BRASIL. Agência Nacional de Telecomunicações. Norma 004/1995. Regula o uso de meios da Rede Pública de Telecomunicações para o provimento e utilização de Serviços de Conexão de Internet. Agência Nacional de Telecomunicações, 1995. Disponível em:

<http://www.anatel.gov.br/Portal/verificaDocumentos/documento.asp?numeroPublica $\mathrm{cao}=10283 \&$ assuntoPublicacao $=$ null $\&$ caminhoRel $=$ null $\&$ filtro $=1 \&$ documentoPath $=b$ iblioteca/Normas/Normas_MC/norma_004_95.htm>. Avesso em: 13 dez. 2016.

BRASIL. Constituição (1988). Disponível em:

<http://www.planalto.gov.br/ccivil_03/constituicao/constituicaocompilado.htm>. Acesso em: 14 nov. 2016.

BRASIL. Decreto $n^{\circ}$ 84.067, de 2 de outubro de 1979. Cria a Secretaria Especial de Informática, como órgão complementar do Conselho de Segurança e dá outras providências. Diário Oficial da União, Brasília, DF, 9 out. 1979. Disponível em: <http://www2.camara.leg.br/legin/fed/decret/1970-1979/decreto-84067-8-outubro1979-433428-publicacaooriginal-1-pe.html>. Acesso em: 20 dez. 2016.

BRASIL. Decreto $n^{\circ} 4.829$, de 3 de setembro de 2003. Dispõe sobre a criação do Comitê Gestor da Internet no Brasil - CGI.br, sobre o modelo de governança da Internet no Brasil, e dá outras providências. Diário Oficial da União, Brasília, DF, 4 set. 2003. Disponível em: <http://www.cgi.br/pagina/decretos/108>. Acesso em: 13 dez. 2016. 
BRASIL. Decreto ${ }^{\circ} 8.771$, de 11 de maio de 2016. Regulamenta a Lei $\mathrm{n}^{\circ} 12.965$, de 23 de abril de 2014, para tratar das hipóteses admitidas de discriminação de pacotes de dados na internet e de degradação de tráfego, indicar procedimentos para guarda e proteção de dados por provedores de conexão e de aplicações, apontar medidas de transparência na requisição de dados cadastrais pela administração pública e estabelecer parâmetros para fiscalização e apuração de infrações. Diário Oficial da União - Edição Extra, Brasília, DF, 11 mai. 2016. Disponível em:

$<$ http://pesquisa.in.gov.br/imprensa/jsp/visualiza/index.jsp?data=11/05/2016\&jornal= 1000\&pagina=7\&totalArquivos=12>. Acesso em: 14 nov. 2016.

BRASIL. Lei no 4.117, de 27 de agosto de 1962. Institui o Código Brasileiro de Telecomunicações. Diário Oficial da União, Brasília, DF, 5 out. 1962. Disponível em: <http://www2.camara.leg.br/legin/fed/lei/1960-1969/lei-4117-27-agosto-1962353835-normaatualizada-pl.pdf >. Acesso em: 20 dez. 2016.

BRASIL. Lei no 4.595, de 31 de dezembro de 1964. Dispõe sobre a Política e as Instituições Monetárias, Bancárias e Creditícias, cria o Conselho Monetário Nacional e dá outras providências. Diário Oficial da União, Brasília, DF, 31 dez. 1964. Disponível em: <http://www.planalto.gov.br/ccivil_03/leis/L4595.htm>. Acesso em: 13 dez. 2016.

BRASIL. Lei $\mathrm{n}^{0}$ 7.232, de 29 de outubro de 1984. Dispõe sobre a Política Nacional de Informática e dá outras providências. Diário Oficial da União, Brasília, DF, 30 out. 1984. Disponível em: < http://www2.camara.leg.br/legin/fed/lei/1980-1987/lei-723229-outubro-1984-356182-normaatualizada-pl.pdf > . Acesso em: 20 dez. 2016.

BRASIL. Lei n ${ }^{\circ} 8.248$, de 23 de outubro de 1991. Dispõe sobre a capacitação e competitividade do setor de informática e automação, e dá outras providências.

Diário Oficial da União, Brasília, DF, 24 out. 1991. Disponível em:

<http://www.planalto.gov.br/ccivil_03/leis/L8248.htm>. Acesso em: 13 dez. 2016.

BRASIL. Lei $n^{\circ}$ 9.472, de 16 de julho de 1997. Dispõe sobre a organização dos serviços de telecomunicações, a criação e funcionamento de um órgão regulador e outros aspectos institucionais, nos termos da Emenda Constitucional no 8, de 1995.

Diário Oficial da União, Brasília, DF, 17 jul. 1997. Disponível em:

$<$ http://pesquisa.in.gov.br/imprensa/jsp/visualiza/index.jsp?jornal=1\&pagina $=1 \&$ data =17/07/1997>. Acesso em: 13 dez. 2016 .

BRASIL. Lei $\mathrm{n}^{\mathrm{o}}$ 12.965, de 23 de abril de 2014. Estabelece princípios, garantias, direitos e deveres para o uso da Internet no Brasil. Diário Oficial da União, Brasília, DF, 24 abr. 2014. Disponível em:

<http://pesquisa.in.gov.br/imprensa/jsp/visualiza/index.jsp?data=24/04/2014\&jornal=

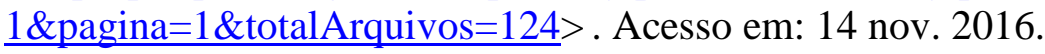

BRASIL. Portaria Interministerial $n^{\circ} 147$, de 31 de maio de 1995. Diário Oficial da União, Brasília, DF, $1^{\circ}$ jun. 1995. Disponível em: 
<http://www.mct.gov.br/index.php/content/view/30310.html>. Acesso em: 13 dez. 2016.

BRASIL. Ministério da Justiça / Secretaria de Direito Econômico. Averiguação preliminar nº 08012.0000387/2000-03. Brasília, DF, 2007.

BRASIL. Norma 4/1995. Regula o uso de meios da Rede Pública de Telecomunicações para o provimento e utilização de Serviços de Conexão à Internet. Disponível em:

$<$ http://www.anatel.gov.br/Portal/verificaDocumentos/documento.asp?numeroPublica $\mathrm{cao}=10283 \&$ assuntoPublicacao $=$ null $\&$ caminhoRel $=$ null $\&$ filtro $=1 \&$ documentoPath $=\mathrm{b}$ iblioteca/Normas/Normas_MC/norma_004_95.htm>. Acesso em: 20 dez. 2016.

BRASIL. Resolução ${ }^{\circ} 3534$ do Banco Central, de 31 de janeiro de 2008. Define termos relacionados aos instrumentos financeiros, para fins de registro contábil.

Banco Central do Brasil, 31 jan. 2008. Disponível em:

<http://www.bcb.gov.br/pre/normativos/busca/downloadNormativo.asp?arquivo=/List s/Normativos/Attachments/47977/Res_3534_v1_O.pdf>. Acesso em: 13 dez. 2016.

\section{WEBSITES CONSULTADOS}

http://banco.bradesco/html/classic/sobre/nossa-historia.shtm

https://www.bcb.gov.br/pt-br/

https://bitcoin.org/

http://www.bradesco.com.br/acessogratis/mobile/regulamento.pdf

https://www.bradescocelular.com.br/site/

http://www.bradescocelular.com.br/termo/termo_de_uso_acesso_gratuito.pdf

http://www.caixa.gov.br/voce/cartoes/pre-pago/tim-multibank/Paginas/default.aspx

http://www.cobra.com.br/index.php/a-empresa/nossa-historia

http://developer.att.com/apis/sponsored-data

https://developers.facebook.com/docs/internet-org?locale=pt_BR

http://www.gsma.com/aboutus/history

http://interatividade.vivo.ddivulga.com/termos_condicoes.html 
http://www.internetlab.org.br/pt/noticias/o-que-esta-em-jogo-na-regulamentacao-domarco-civil-da-internet/

http://jfinvest.com.br/quem-somos/apresentacao/

http://www.netshoes.com.br/navegue-gratis/regulamento

http://www.netshoes.com.br/institucional/index.jsp

http://occupywallst.org/about/

https://r3cev.com/about/

http://www.sinditelebrasil.org.br/quem-somos/nossa-historia

https://www.swift.com/about-us/history

http://www.zuum.com.br/como-funciona 
APÊNDICE - Cronologia do desenvolvimento da internet e da automação bancária brasileira

\begin{tabular}{|c|c|c|c|c|}
\hline $\begin{array}{c}\text { Fases do } \\
\text { desenvolvimento } \\
\text { da internet }\end{array}$ & Ano & $\begin{array}{c}\text { Principais eventos } \\
\text { ligados ao } \\
\text { desenvolvimento da } \\
\text { internet }\end{array}$ & $\begin{array}{c}\text { Principais eventos } \\
\text { ligados ao } \\
\text { desenvolvimento da } \\
\text { internet no Brasil }\end{array}$ & $\begin{array}{c}\text { Eventos ligados ao } \\
\text { desenvolvimento dos } \\
\text { bancos e à tecnologia } \\
\text { bancária }\end{array}$ \\
\hline \multirow{10}{*}{$\begin{array}{c}\text { Antecedentes } \\
\text { históricos }\end{array}$} & 1943 & & & - Fundação do Bradesco \\
\hline & 1957 & $\begin{array}{l}\text { - Lançamento do } \\
\text { Sputinik I }\end{array}$ & $\begin{array}{l}\text { - Governo do Estado de } \\
\text { S. Paulo adquire } \\
\text { computador }\end{array}$ & \\
\hline & 1958 & - Fundação da Arpa & $\begin{array}{l}\text { - JK autoriza governo a } \\
\text { estudar a utilização de } \\
\text { computadores no } \\
\text { âmbito do Plano de } \\
\text { Metas }\end{array}$ & \\
\hline & 1961 & & $\begin{array}{l}\text { - Criação do CONTEL } \\
\text { - Zezinho: Primeiro } \\
\text { computador projetado e } \\
\text { construído no Brasil }\end{array}$ & $\begin{array}{l}\text { - Bradesco instala seu } \\
\text { primeiro computador }\end{array}$ \\
\hline & 1962 & $\begin{array}{l}\text { - Memorandos } \\
\text { Linklider }\end{array}$ & $\begin{array}{l}\text { - Código Brasileiro de } \\
\text { Telecomunicações }\end{array}$ & $\begin{array}{l}\text { - Banco Nacional adquire } \\
\text { um computador }\end{array}$ \\
\hline & 1964 & & $\begin{array}{l}\text { - Golpe militar no } \\
\text { Brasil } \\
\text { - Criação do Serpro }\end{array}$ & $\begin{array}{l}\text { - Criação do Conselho } \\
\text { Monetário Nacional e do } \\
\text { Banco Central do Brasil }\end{array}$ \\
\hline & 1965 & & - Criação da Embratel & $\begin{array}{l}\text { - Instituição do Conselho } \\
\text { Monetário Nacional } \\
\text { - Itaú implanta seu CPD } \\
\text { com um computador da } \\
\text { IBM }\end{array}$ \\
\hline & 1966 & $\begin{array}{l}\text { - Robert Taylor dá } \\
\text { início as pesquisas } \\
\text { para desenvolver a } \\
\text { rede de computadores }\end{array}$ & & \\
\hline & 1967 & & $\begin{array}{l}\text {-Contel é incorporado } \\
\text { ao Ministério das } \\
\text { Comunicações }\end{array}$ & $\begin{array}{l}\text { - Fundação da } \\
\text { FEBRABAN } \\
\text { - Primeiro caixa } \\
\text { eletrônico do mundo é } \\
\text { instalado em uma agência } \\
\text { do banco Barclays em } \\
\text { Londres }\end{array}$ \\
\hline & 1968 & & & $\begin{array}{l}\text { - Bamerindus adquire um } \\
\text { computador }\end{array}$ \\
\hline \multirow[t]{3}{*}{$1^{\text {a }}$ Fase } & 1969 & $\begin{array}{l}\text { - Instalação do } \\
\text { Interface Message } \\
\text { Processor em UCLA } \\
\text { - Primeiras conexões } \\
\text { da ARPANET }\end{array}$ & & \\
\hline & 1972 & $\begin{array}{l}\text { - Desenvolvimento do } \\
\text { arquétipo do e-mail }\end{array}$ & $\begin{array}{l}\text { - Criação da Telebras } \\
\text { - Criação da CAPRE } \\
\text { - USP elabora } \\
\text { computador "Patinho } \\
\text { Feio" }\end{array}$ & \\
\hline & 1973 & $\begin{array}{l}\text { - Vinton Cerf e Robert } \\
\text { Kahn começam a } \\
\text { desenvolver o } \\
\text { protocolo TPC/IP }\end{array}$ & & $\begin{array}{l}\text { - Fundação da Eletrônica } \\
\text { Digital Brasileira (EDB) } \\
\text { - É criada em Genebra a } \\
\text { Sociedade de } \\
\text { Telecomunicações } \\
\text { Financeiras Interbancárias }\end{array}$ \\
\hline
\end{tabular}




\begin{tabular}{|c|c|c|c|c|}
\hline & & & & $\begin{array}{l}\text { Mundiais (SWIFT, na } \\
\text { sigla em inglês) }\end{array}$ \\
\hline & \multicolumn{2}{|l|}{1974} & - II PND & $\begin{array}{l}\text { - EDB passa a se chamar } \\
\text { Digibrás } \\
\text { - Fundação da Cobra }\end{array}$ \\
\hline & \multicolumn{2}{|l|}{1975} & $\begin{array}{l}\text { - Governo passa a } \\
\text { adotar medidas de } \\
\text { controle às importações } \\
\text { - Primeira } \\
\text { demonstração da } \\
\text { ARPANET no Brasil } \\
\text { - Decreto } 301 \text { delega à } \\
\text { Embratel a tarefa de } \\
\text { instalar e explorar a } \\
\text { rede nacional de dados }\end{array}$ & - Fundação da Scopus \\
\hline & \multicolumn{2}{|l|}{1976} & & $\begin{array}{l}\text { - Criação da Comissão de } \\
\text { Valores Monetários } \\
\text { - Fundação da Prológica e } \\
\text { da Digirede }\end{array}$ \\
\hline & 1977 & - Invenção do DOS & & $\begin{array}{l}\text { - Fundação da } \\
\text { Embracomp } \\
\text { - SWIFT lança sua rede } \\
\text { de telecomunicações } \\
\text { mundial para troca de } \\
\text { mensagens financeiras }\end{array}$ \\
\hline & 1978 & $\begin{array}{l}\text { - Invenção do modem } \\
\text { - Criação do } \\
\text { Intergovernamental } \\
\text { Bureau for Informatics }\end{array}$ & & - Fundação da SID \\
\hline & 1979 & & $\begin{array}{l}\text { - Criação da Secretaria } \\
\text { Especial de Informática } \\
\text { (SEI) }\end{array}$ & $\begin{array}{l}\text { - Fundação do Itautec } \\
\text { - Fundação do Digilab }\end{array}$ \\
\hline \multirow[t]{8}{*}{$2^{\mathrm{a}}$ Fase } & 1980 & $\begin{array}{l}\text { - Criação da CSNET e } \\
\text { da BITNET } \\
\text { - Publicação do } \\
\text { Relatório MacBride }\end{array}$ & $\begin{array}{l}\text { - Criação da rede } \\
\text { TransData }\end{array}$ & $\begin{array}{l}\text { - Lançamento do primeiro } \\
\text { minicomputador } \\
\text { brasileiro, o Cobra } 530\end{array}$ \\
\hline & 1981 & & & $\begin{array}{l}\text { - Bradesco e Itaú } \\
\text { inauguram primeiras } \\
\text { agências automatizada }\end{array}$ \\
\hline & 1982 & $\begin{array}{l}\text { - Lançamento } \\
\text { comercial do Minitel } \\
\text { na França }\end{array}$ & $\begin{array}{l}\text { - Implantação da rede } \\
\text { Ciranda }\end{array}$ & \\
\hline & 1983 & $\begin{array}{l}\text { - Divisão da } \\
\text { ARPANET em } \\
\text { MILNET e } \\
\text { ARPANET }\end{array}$ & & $\begin{array}{l}\text { - Primeiro caixa } \\
\text { eletrônico do país é } \\
\text { instalado em uma agência } \\
\text { do banco Itaú }\end{array}$ \\
\hline & 1984 & $\begin{array}{l}\text { - Criação do DNS } \\
\text { - Desmembramento da } \\
\text { AT\&T: marco inicial } \\
\text { da Reforma das } \\
\text { Telecomunicações nos } \\
\text { EUA }\end{array}$ & $\begin{array}{l}\text { - Política Nacional de } \\
\text { Informática (Lei } \mathrm{n}^{\circ} \\
7.232 / 84)\end{array}$ & \\
\hline & 1985 & & $\begin{array}{l}\text { - Criação da Rede } \\
\text { Renpac } \\
\text { - Implantação da rede } \\
\text { Cirandão }\end{array}$ & \\
\hline & 1986 & & & $\begin{array}{l}\text { - Lançamento do Plano } \\
\text { Cruzado }\end{array}$ \\
\hline & 1988 & & $\begin{array}{l}\text { - Promulgação da } \\
\text { Constituição Federal } \\
\text { - LNCCC e FAPESP } \\
\text { conectam-se à BITNET }\end{array}$ & \\
\hline
\end{tabular}




\begin{tabular}{|c|c|c|c|c|}
\hline & \multicolumn{2}{|l|}{1989} & \multirow{2}{*}{$\begin{array}{l}\text { - UFRJ conecta-se à } \\
\text { BITNET } \\
\text { - Criação da RNP } \\
\text { - SEI é substituída pela } \\
\text { DEPIN e MCT é } \\
\text { transformado em } \\
\text { Secretaria de Ciência e } \\
\text { Tecnologia. }\end{array}$} & \multirow{2}{*}{$\begin{array}{l}\text { - Fundação da empresa } \\
\text { Tecnologia Bancária } \\
\text { (TecBan) } \\
\text { - Mais de } 77 \text { mil postos de } \\
\text { trabalho são fechados no } \\
\text { setor bancário brasileiro }\end{array}$} \\
\hline & 1990 & $\begin{array}{l}\text { - Desativação da } \\
\text { ARPANET } \\
\text { - Desenvolvimento do } \\
\text { WWW }\end{array}$ & & \\
\hline & 1991 & & $\begin{array}{l}\text { - Lei } \mathrm{n}^{\circ} 8.248 / 1991 \\
\text { estabelece o fim da } \\
\text { reserva de mercado do } \\
\text { setor de informática }\end{array}$ & \\
\hline & 1992 & - Invenção do Mosaic & $\begin{array}{l}\text { - Rio } 92 \\
\text { - Instalação do } \\
\text { backbone da RNP }\end{array}$ & $\begin{array}{l}\text { - Bradesco adquire } 19 \% \\
\text { das ações da Sharp no } \\
\text { Brasil }\end{array}$ \\
\hline & 1994 & & & $\begin{array}{l}\text { - Lançamento do Plano } \\
\text { Real } \\
\text { - Venda de aparelhos de } \\
\text { informática para bancos } \\
\text { no Brasil soma US\$ 4,1 } \\
\text { bilhão } \\
\text { - Fundação do banco } \\
\text { Opportunity }\end{array}$ \\
\hline \multirow[t]{6}{*}{$3^{a}$ Fase } & 1995 & $\begin{array}{l}\text { - Privatização da } \\
\text { NSFNET } \\
\text { - Resolução FNC } \\
\text { define o termo } \\
\text { "Internet" } \\
\text { - Fundação do Yahoo! } \\
\text { - Lançamento do } \\
\text { MSN } \\
\text { - Microsoft lança } \\
\text { Internet Explorer } 1.0\end{array}$ & $\begin{array}{l}\text { - Norma 4/1995 } \\
\text { - Criação do CGI.br } \\
\text { - Criado serviço de } \\
\text { busca Cadê }\end{array}$ & $\begin{array}{l}\text { - Bradesco, quarto maior } \\
\text { banco em ativos do país, } \\
\text { lança primeiro site } \\
\text { comercial do Brasil } \\
\text { - Grupo de seis maiores } \\
\text { bancos no Brasil } \\
\text { concentram 60,5\% do } \\
\text { total de ativos } \\
\text { - Governo federal lança } \\
\text { PROER } \\
\text { - Wells Fargo é um dos } \\
\text { primeiros bancos a } \\
\text { oferecer internet banking } \\
\text { - First Digital Bank } \\
\text { registrava } 50 \text { mil clientes } \\
\text { e duas mil empresas } \\
\text { - Em outubro é fundado, } \\
\text { nos Estados Unidos, o } \\
\text { Security First Network } \\
\text { Bank, primeiro banco } \\
\text { unicamente virtual }\end{array}$ \\
\hline & 1996 & $\begin{array}{l}\text { - Nokia lança primeiro } \\
\text { aparelho celular com } \\
\text { internet móvel } \\
\text { - Lançamento do } \\
\text { Hotmail } \\
\text { - Lançamento do ICQ }\end{array}$ & - Fundação da Abranet & $\begin{array}{l}\text { - Bradesco lança o } \\
\text { primeiro serviço de } \\
\text { internet banking do Brasil } \\
\text { - Governo federal lança } \\
\text { PROES }\end{array}$ \\
\hline & 1997 & & $\begin{array}{l}\text { - Lei Geral das } \\
\text { Telecomunicações } \\
\text { - Criação da Anatel }\end{array}$ & \\
\hline & 1998 & $\begin{array}{l}\text { - Fundação do Google } \\
\text { - Lançamento do } \\
\text { FreeServe }\end{array}$ & & \\
\hline & 1999 & $\begin{array}{l}\text { - Lançamento do } \\
\text { MSN Messenger }\end{array}$ & $\begin{array}{l}\text { - Starmedia compra o } \\
\text { site de busca Cadê } \\
\text { - Telefónica compra } \\
\text { provedor de acesso } \\
\text { ZAZ }\end{array}$ & $\begin{array}{l}\text { - Bradesco anuncia } \\
\text { internet grátis para seus } \\
\text { correntistas, "Rede } \\
\text { Acesso Grátis" }\end{array}$ \\
\hline & 2000 & $\begin{array}{l}\text { - Fusão AOL e Time } \\
\text { Warner }\end{array}$ & $\begin{array}{l}\text { - MCT lança a } \\
\text { publicação "Sociedade }\end{array}$ & $\begin{array}{l}\text { - No Brasil, } 50 \% \text { dos } \\
\text { bancos já oferecem }\end{array}$ \\
\hline
\end{tabular}




\begin{tabular}{|c|c|c|c|c|}
\hline & & $\begin{array}{l}\text { - Fusão Vivendi, } \\
\text { Canal Plus e Seagram } \\
\text { - Estouro da "bolha da } \\
\text { internet" } \\
\text { - Expansão de } \\
\text { servidores gratuitos de } \\
\text { internet } \\
\text { - Internet nos Estados } \\
\text { Unidos: 106,3 milhões } \\
\text { de usuários; 53,1 } \\
\text { milhões de hosts }\end{array}$ & $\begin{array}{l}\text { de Informação no Brasil } \\
\text { - Livro Verde" } \\
\text { - Lançamento do iG } \\
\text { - Telecom Itália compra } \\
\text { 30\% da Globo.com } \\
\text { - Internet no Brasil: } \\
\text { 6,79 milhões de } \\
\text { usuários; } 446.444 \text { hosts; } \\
\text { e } 174.163 \text { domínios }\end{array}$ & $\begin{array}{l}\text { internet banking. Nos } \\
\text { Estados Unidos, taxa é de } \\
11,3 \% \\
\text { - Bradesco e Itaú } \\
\text { oferecem serviços de } \\
\text { internet banking em } \\
\text { celulares com tecnologia } \\
\text { WAP }\end{array}$ \\
\hline \multirow[t]{10}{*}{$4^{a}$ fase } & 2001 & $\begin{array}{l}\text { - Fundação da } \\
\text { Wikipedia }\end{array}$ & & $\begin{array}{l}\text { - Internet banking no } \\
\text { Brasil: } 8,3 \text { milhões de } \\
\text { usuários } \\
\text { - Governo federal lança } \\
\text { PROEF }\end{array}$ \\
\hline & 2002 & $\begin{array}{l}\text { - Lançamento do } \\
\text { Fotolog }\end{array}$ & & $\begin{array}{l}\text { - Internet banking no } \\
\text { Brasil: } 13 \text { milhões de } \\
\text { usuários; } 2,2 \text { bilhões de } \\
\text { operações } \\
\text { - Internet banking nos } \\
\text { EUA: } 37 \text { milhões de } \\
\text { usuários }\end{array}$ \\
\hline & 2003 & $\begin{array}{l}\text { - Lançamento do } \\
\text { Linkedin e o MySpace } \\
\text { - Lançamento do jogo } \\
\text { Second Life }\end{array}$ & $\begin{array}{l}\text { - Criação do Nic Br, } \\
\text { entidade civil sem fins } \\
\text { lucrativos com o } \\
\text { objetivo de implementar } \\
\text { as decisões e projetos } \\
\text { do CGI.br }\end{array}$ & $\begin{array}{l}\text { - Internet banking no } \\
\text { Brasil: } 14,9 \text { milhões de } \\
\text { usuários }\end{array}$ \\
\hline & 2004 & $\begin{array}{l}\text { - Lançamento do } \\
\text { Flickr, Orkut e } \\
\text { Facebook } \\
\text { - Lançamento do } \\
\text { Gmail } \\
\text { - Lançamento do } \\
\text { browser Firefox } 1.0\end{array}$ & & \\
\hline & 2005 & $\begin{array}{l}\text { - Lançamento do } \\
\text { Youtube } \\
\text { - Número de } \\
\text { internautas no mundo: } \\
1 \text { bilhão }\end{array}$ & & $\begin{array}{l}\text { - Internet banking nos } \\
\text { EUA: } 53 \text { milhões de } \\
\text { usuários }\end{array}$ \\
\hline & 2006 & $\begin{array}{l}\text { - Lançamento do } \\
\text { Twitter } \\
\text { - Criação do site } \\
\text { Wikileaks }\end{array}$ & $\begin{array}{l}\text { - } 1 \text { milhão de domínios } \\
\text { ".br" registrados }\end{array}$ & \\
\hline & 2007 & $\begin{array}{l}\text { - Apple anuncia o } \\
\text { lançamento do } \\
\text { primeiro Iphone }\end{array}$ & & \\
\hline & 2008 & $\begin{array}{l}\text { - Lançamento do } \\
\text { browser Google } \\
\text { Chrome } \\
\text { - Nave espacial da } \\
\text { NASA envia e recebe } \\
\text { mensagens por meio } \\
\text { de tecnologia DTN a } \\
32 \text { milhões de } \\
\text { quilômetros da } \\
\text { superfície terrestre }\end{array}$ & & $\begin{array}{l}\text { - Pedido de falência do } \\
\text { banco estadunidense } \\
\text { Lehman Brothers e início } \\
\text { da crise financeira } \\
\text { mundial } \\
\text { - Fusão do Itaú de do } \\
\text { Unibanco } \\
\text { - Banco do Brasil compra } \\
\text { banco paulista Nossa } \\
\text { Caixa }\end{array}$ \\
\hline & 2009 & $\begin{array}{l}\text { - Lançamento do } \\
\text { Whatsapp }\end{array}$ & & \\
\hline & 2010 & $\begin{array}{l}\text { - Lançamento do } \\
\text { Instagram }\end{array}$ & & \\
\hline
\end{tabular}


- Primavera árabe

- Wikileaks publica

conjunto de

telegramas

diplomáticos dos

Estados Unidos

(Cablegate)

2011 - Lançamento do

Snapchat

- Occupy Wall Street

- Número de

internautas no mundo:

2 bilhões

2012 - Facebook compra - 3 milhões de domínios

Instagram por US\$ “.br" registrados

750 milhões

- Minitel é tirado de

funcionamento na

França

2013 - Vazamento de dados - Jornadas de Junho secretos da NSA

- Lançamento do

Telegram

- Facebook funda o

Internet.org

- Cobra passa a se chamar BB Tecnologia e Serviços

2014 - Facebook compra

Whatsapp por US\$ 22

bilhões

- Lançamento do

Google Glass
- Brasil sedia encontro

- Marco Civil da

Internet é sancionado

- Internautas no Brasil:

94,2 milhões
Net Mundial

- Bradesco lança

campanha Acesso

Gratuito ao Bradesco

celular

- Bradesco é o quarto maior banco do Brasil em ativos ( $\mathrm{R} \$ 955,9$ bilhões)

- Grupo de seis maiores

bancos no Brasil

concentram $82,5 \%$ do

total de ativos

- Mobile banking no

Brasil: 25 milhões de contas com acesso via celular; 4,7 bilhões de transações

\begin{tabular}{|c|c|c|c|}
\hline 2015 & $\begin{array}{l}\text { - Verizon compra a } \\
\text { AOL por US\$ } 4 \\
\text { bilhões } \\
\text { - Número de } \\
\text { internautas: } 3,1 \\
\text { bilhões }\end{array}$ & $\begin{array}{l}\text { - Início da campanha } \\
\text { "Navegue Grátis" do } \\
\text { grupo Netshoes }\end{array}$ & $\begin{array}{l}\text { - Taxa de bancarização no } \\
\text { Brasil chega a } 89,6 \% \\
\text { - Mobile banking no } \\
\text { Brasil: } 33 \text { milhões de } \\
\text { contas com acesso via } \\
\text { celular; } 11,2 \text { bilhões de } \\
\text { transações } \\
\text { - No Brasil, transações } \\
\text { realizadas pelo internet } \\
\text { banking e mobile banking } \\
\text { correspondem a } 54 \% \text { dos } \\
\text { atendimentos bancários }\end{array}$ \\
\hline 2016 & $\begin{array}{l}\text { - Verizon compra o } \\
\text { Yahoo por US } \$ 4,83 \\
\text { bilhões } \\
\text { - NASA instala } \\
\text { tecnologia DTN na } \\
\text { Estação Espacial } \\
\text { Internacional } \\
\text { - Órgão regulador de } \\
\text { telecomunicações }\end{array}$ & $\begin{array}{l}\text { - Presidente Dilma } \\
\text { Rousseff regulamenta o } \\
\text { Marco Civil da Internet } \\
\text { no último dia de seu } \\
\text { mandato } \\
\text { - Vivo anuncia } \\
\text { programa de dados } \\
\text { patrocinados }\end{array}$ & $\begin{array}{l}\text { - Em junho, Bradesco é o } \\
\text { quarto maior banco no } \\
\text { total de ativos com R\$ } \\
955 \text { milhões } \\
\text { - Processo de compra do } \\
\text { HSBC pelo Bradesco é } \\
\text { concluído } \\
\text { - Lançamento do Banco } \\
\text { Original }\end{array}$ \\
\hline
\end{tabular}




\begin{tabular}{lll}
\hline & indiano proíbe & - Início da campanha de \\
Internet.org e & internet grátis da \\
& Freebasics.com no & Privalia \\
país & \\
- AT\&T anuncia a & \\
compra da Time & \\
Warner por US\$ 108, & \\
7 bilhões & \\
\hline
\end{tabular}

Fonte: Elaborada pela autora 